UNIVERSITAT POLITÈCNICA DE VALÈNCIA

PhD in Biotechnology

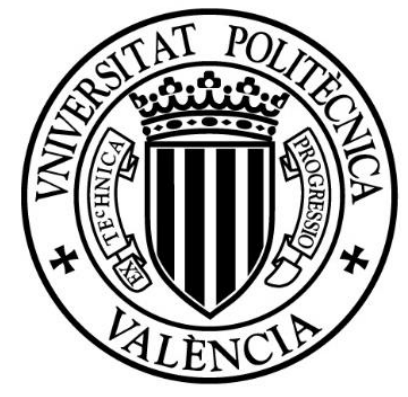

\title{
TOLL LIKE RECEPTORS IN SPINAL CORD DERIVED NEURAL PRECURSOR \\ CELLS: IMPLICATIONS ON SPINAL CORD INJURY AND CELL TRANSPLANTATION
}

\author{
PhD. THESIS \\ Submitted by \\ Marina Sánchez Petidier \\ Valencia, December 2021
}

PhD. Supervisors:

Dra. Victoria Moreno Manzano

Dra. Consuelo Guerri Sirera

UPV Mentoring:

Dra. Esther Giraldo Reboloso 


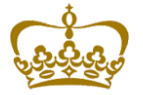

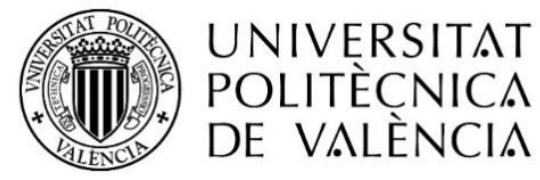

Dr Victoria Moreno Manzano, PhD in Pharmacy and Head of the Neuronal and Tissue Regeneration Laboratory and Dr Consuelo Guerri Sirera, $\mathrm{PhD}$ in Biology and Head of the Pathology Laboratory at the Centro de Investigación Príncipe Felipe,

CERTIFY that the work

"TOLL LIKE RECEPTORS IN SPINAL CORD DERIVED NEURAL PRECURSOR CELLS: IMPLICATIONS ON SPINAL CORD INJURY AND CELL TRANSPLANTATION"

has been developed by Marina Sánchez Petidier under her supervision in the Centro de Investigación Príncipe Felipe, as a Thesis Project to obtain a $\mathrm{PhD}$ degree in Biotechnology from the Universitat Politècnica de València.

Valencia, December 2021

Dra. Victoria Moreno Manzano Dra. Consuelo Guerri Sirera 
A mi padre 
"La ciencia está llena de errores que son útiles cometer ya que nos acercan poco a poco hacia la verdad"

-Julio Verne 


\section{AGRADECIMIENTOS}

En primer lugar, me gustaría agradecerle al CIPF por darme la oportunidad de realizar mi tesis doctoral, lo que me ha permitido conocer a gente maravillosa y participar en este proyecto que he disfrutado tanto, dirigido por las doctoras Consuelo Guerri y Victoria Moreno. Chelo, quiero agradecerte toda la ayuda que me has brindado estos años y por trasmitirme toda la energía que te caracteriza. Vicky, agradecerte tu paciencia y la confianza que has depositado en mí todos estos años inspirándome y consiguiendo que no me diera por vencida.

Hacer la tesis entre dos laboratorios tiene la ventaja de haber podido conocer al doble de personas maravillosas en la aventura que ha sido esta tesis. Tengo tanto que deciros de corazón y tan poco espacio para decíroslo que los agradecimientos ocuparían más que la propia tesis, así que intentaré ser breve.

Del I05, a Juan y Majo, que siempre habéis sido el faro de la alegría del lab y una guía inestimable en todo mi aprendizaje. A Carlos y Paco, los “martes y 13" del I05, por todos esos ratos que he podido compartir con vosotros de consuelo delante de la máquina de café y de risas. A Susana, la "bonica" que llegó y me conquistó, tanto por tu insuperable gestión del animalario como por todo lo que me has aportado a nivel personal. Y yo no podría hablar del I05 sin mi Rosa, mi primera compañera de batallas y que siempre me has cuidado como a una hermana, preocupada siempre antes por mi bienestar que porque no salieran las proteínas en el western.

Del I44 me llevo una familia académica con la que he tenido la suerte de terminar coincidiendo los mismos que empezamos esta odisea hace 4 años. A Esther por toda tu preocupación por mí y por la grandísima ayuda que me has brindado, como compañera y amiga. A Ana, por enseñarme todo lo que hoy sé de cuidar animales, no solo me has enseñado a hacerlo, sino también a 
disfrutarlo. A Eric, tu ayuda y apoyo personal siempre ha sido crucial para el desarrollo de esta tesis. A Mara, nuestra mami, por haber sido la persona que más me ha cuidado y mimado todos estos años. Gracias por haber tenido todas aquellas largas charlas, risas, momentos de llorar y de aprender juntas. Por último, mis polluelos, a Pablo, cada día contigo ha sido una aventura divertida y esos ratos en el despacho contigo de compañero han sido insustituibles. A Sonia, mi compañera de despacho con la que he compartido tantas jornadas de 24/7, por todos los buenos momentos juntas llenos de risas. A Bea, muchas gracias por tu alegría y tu cariño estos años chimuelita. A María del Mar, por compartir esta última etapa conmigo, sigue disfrutando de la tesis y de la ciencia. Y a Neus, nuestra última polluela, espero que este genial equipo te haga sentir tan querida como me lo han hecho sentir a mí.

A las italianas que me robaron el corazón, Giulia y Elly, por todos los momentos que hemos pasado juntas (y no solo en la sala de cultivos).

I would like to thank professor Elizabeth Bradbury for the wonderful welcome she gave me during the months I was working with her. Y por supuesto a mi gran amigo Isaac, por todo lo que me has enseñado y tu paciencia, ojalá volvamos a trabajar juntos en el futuro.

Agradecer por supuesto, a los servicios de microscopia, citómica y animalario del CIPF por su ayuda e infinita paciencia. En especial a Viviana, por todos sus consejos y por enseñarme en mis primeras cirugías.

A mi familia y a mis niñas Sandra, Bea y Leo, por vuestra increíble comprensión en cada quedada cuando tenía que ir al laboratorio a cuidar ratoncitos, al microscopio o ver que mis células tuvieran comida. Gracias por comprender que esto es más que un trabajo donde la dedicación es completa y por vuestro apoyo. 
A mis padres, José Vicente e Isabel, gracias por el infinito amor y apoyo que me habéis dado siempre. Me habéis enseñado el mejor consejo que se puede dar, aplicable en ciencia y en la vida misma, y es que sin errores no alcanzaríamos nunca la verdad. Sin vuestros consejos no habría llegado hasta aquí, gracias.

Por último, voy a escribir las líneas que más ganas tenía de escribir porque hace 5 años y medio dejaste la pelota en mi tejado con una, según tú, "no declaración de amor" en tu TFM y ahora es mi turno. Citando una frase que dijo un ingeniero químico: "el destino me ha brindado un regalo enorme al hacernos trabajar en el mismo equipo"; lo que no sabía en ese momento es que ese equipo continuaría por muchos años más, y que no te referías al mismo lab team. Ese sentimiento de equipo lo hemos sabido mantener a pesar de separar nuestros campos de trabajo lo que me ha permitido admirar y agradecer cada día más todo lo que haces por mí. Y estos últimos 4 años, has estado apoyándome más que nadie en todas y cada una de las decisiones profesionales que he tomado; has llorado, reído, gritado, divertido y sufrido conmigo cada minuto de esta tesis a mi lado y como siempre, sin pedir nada a cambio porque sabes mejor que nadie lo que significa para mi ser investigadora. Gracias Adri, y mil veces gracias por formar parte de esta tesis y de mi vida.

¡Muchas gracias a todos! 


\section{FINANCIAL SUPPORT}

The student has been granted with a $\mathrm{PhD}$ fellowship from a predoctoral program at the CIPF and with International Research and Training Exchange Programme at the CIPF. This work has been supported by the Spanish Ministry of Economy and Competitiveness (projects RTI2018-095872-B-C21; MAT2015-66666-C3-R; SAF2015-69187R) and Spanish Ministry of Heath, PNSD2018 I003. 


\section{RESUMEN}

Los receptores tipo Toll, TLR, son receptores clave en la defensa contra los patógenos capaces de iniciar la respuesta inmunitaria innata para proteger al huésped. Su papel no solo se relega a responder a estímulos foráneos, sino que también pueden detectar daños en los tejidos o células lesionadas induciendo su respuesta a lo que se conoce como "inflamación estéril". Las células del sistema inmunitario no son las únicas que presentan TLR; también se encuentran en células de la glía, neuronas y precursores neurales (NPC). Concretamente, TLR2 y TLR4 en NPC en cerebro contribuyen a la determinación del destino celular y plasticidad neuronal durante el desarrollo. Sin embargo, sus funciones en la fisiología y patología de la médula espinal no están bien definidas, así como en procesos críticos como la neurogénesis, autorrenovación o proliferación. Esta tesis doctoral, distribuida entre tres capítulos, se ha centrado 1) en el estudio del papel de TLR2 y TLR4 en precursores derivados de medula espinal neonatal (Capitulo 1); 2) en evaluar el papel de ambos, TLR2 y TLR4 en el proceso de regeneración espontánea o tras trasplante ectópico de NPC, en un modelo de lesión medular inducida (Capítulo 2); 3) en el estudio del papel de TLR4 en la modulación del fenotipo inflamatorio en respuesta al proteoglicano condroitín sulfato (CSPG) secretado tras la lesión medular con actividad inhibitoria del recrecimiento axonal tras lesión medular (Capítulo 3).

En el capítulo 1, empleando ratones neonatales deficientes 
para TLR2 o TLR4, se describe la relevancia de ambos receptores en el mantenimiento de la población de precursores neurales, positivos para SOX2 en la médula espinal neonatal. Además, observamos que la expresión de TLR2 limita su capacidad de proliferación y auto-renovación favoreciendo su diferenciación neural, mientras que la expresión de TL4 la limita, posiblemente mediado a través de la expresión diferencial de Neurogenina1. Y ambos receptores resultan necesarios en la maduración de los precursores de oligodendrocitos.

En el capítulo 2, se evalúa la influencia de TLR2 y TLR4 tanto en la regeneración espontánea tras una lesión medular como en la tolerancia, en términos de supervivencia e integración, al trasplante de precursores neurales. La ausencia de TLR4 genera un déficit significativo en la regeneración espontánea de la capacidad locomotora en comparación con animales de la cepa salvaje. La ausencia de TLR4 disminuye significativamente la preservación de los tractos neuronales en el epicentro de la lesión y la ausencia de TLR2 genera una mayor área de lesión. En el estudio del papel de TLR2 y TLR4 en NPC trasplantados tras una lesión medular encontramos que aquellos NPC carentes de TLR4 confieren una mejor preservación de las fibras neuronales en la región caudal a la lesión, con un incremento significativo en la expresión de BDNF. Sin embargo, el trasplante de NPC carentes de TLR2 genera una mayor área de lesión con un aumento en la expresión de STAT3. Por otro lado, el trasplante de NPC, con o sin TLR2 o TLR4, en el 
modelo de lesión medular compresiva severa, no mejoró en ningún caso significativamente la actividad locomotriz en comparación con los animales no trasplantados. Sin embargo, el trasplante de NPC en animales carentes de TLR4 - cuya capacidad de regeneración espontánea está muy limitada- mejora la preservación de fibras neuronales en el epicentro de la lesión.

En el capítulo 3 se describe el papel de TLR4 en la modulación del fenotipo inflamatorio de los macrófagos en respuesta a CSPG empleando un inhibidor específico de este receptor y macrófagos procedentes de ratones carentes del mismo. Los resultados indican que los CSPG inducen un fenotipo proinflamatorio en macrófagos M2 o antiinflamatorios, mediado por TLR4, ya que la ausencia tanto de la actividad como de su expresión impide la inducción de IL1 $\beta$, TNF $\alpha$ o iNOS en presencia de CSPGs.

En conclusión, podemos afirmar que TLR2 y TLR4 poseen un papel relevante durante la maduración e identidad celular de los NPC en medula espinal neonatal sana. Tras una lesión medular, en el individuo adulto, ambos receptores influyen positivamente en su regeneración espontánea, sin embargo, la presencia de TLR4 podría limitar la capacidad neuroprotectora tras un trasplante de NPC de forma ectópica y contribuir a extender y mantener las respuestas pro-inflamatorias. Es por todo ello que, el estudio más detallado del papel de TLR2 y TLR4 y su contribución tras una lesión medular podría contribuir a esclarecer mecanismos 
relacionados con su inducción y resolución, constituyendo además una potencial diana de trabajo en las estrategias de terapia, incluida la terapia celular basada en el uso de NPC. 


\section{RESUM}

Els receptors tipus Toll, TLR, són receptors clau en la defensa contra els patògens capaços d'iniciar la resposta immunitària innata per a protegir l'hoste. El seu paper no sols es relega a respondre a estímuls forans, sinó que també poden detectar danys en els teixits o cèl-lules lesionades induint la seua resposta al que es coneix com a "inflamació estèril". Les cèl-lules del sistema immunitari no són les úniques que presenten TLR; també es troben en cèl-lules de la glia, neurones i precursors neurals (NPC). TLR2 i TLR4 en NPC en cervell contribueixen a la determinació del destí cel·lular i plasticitat neuronal. No obstant això, les seues funcions en la fisiopatologia de la medul·la espinal no estan ben definides, així com en processos crítics com la neurogènesi, autorenovació o proliferació. Aquesta tesi doctoral, distribuïda entre tres capítols, s'ha centrat: 1) En l'estudi del paper de TLR2 i TLR4 en precursors derivats de medul·la espinal neonatal (Capítol 1); 2) A avaluar el paper de tots dos, TLR2 i TLR4, en el procés de regeneració espontània o després de trasplantament ectòpic de NPC, en un model de lesió medul-lar induïda (Capítol 2); 3) En l'estudi del paper de TLR4 en la modulació del fenotip inflamatori en resposta al proteoglicà condroití sulfat (CSPG) secretat després de la lesió medul-lar amb activitat inhibitòria del recreixement axonal després de lesió medul·lar (Capítol 3). 
En el capítol 1, emprant ratolins neonatals deficients per a TLR2 o TLR4, es descriu la rellevància de tots dos receptors en el manteniment de la població de precursors neurals, positius per a SOX2 en la medul·la espinal neonatal. A més, l'expressió de TLR2, limita la seua capacitat de proliferació i autorenovació afavorint la seua diferenciació neural, mentre que l'expressió de TLR4 la limita, possiblement mediat a través de l'expressió diferencial de Neurogenina1. Tots dos receptors resulten necessaris en la maduració dels precursors de oligodendrocitos.

En el capítol 2, s'avalua la influència de TLR2 i TLR4 tant en la regeneració espontània després d'una lesió medul·lar com en la tolerància, en termes de supervivència i integració al trasplantament de precursors neurales. L'absència de TLR4 genera un dèficit significatiu en la regeneració espontània de la capacitat locomotora en comparació amb animals del cep salvatge. L'absència de TLR4 disminueix significativament la preservació dels tractes neuronals en l'epicentre de la lesió i l'absència de TLR2 genera una major àrea de lesió. En l'estudi del paper de TLR2 i TLR4 en NPC trasplantades després d'una lesió medul-lar trobem que aquelles NPC mancades de TLR4 confereixen una millor preservació de les fibres neuronals a la regió cabal a la lesió, amb un increment significatiu en l'expressió de BDNF. No obstant això, el trasplantament de NPC mancats de TLR2 genera una major àrea de lesió amb un 
augment en l'expressió de STAT3. D'altra banda, el trasplantament de NPC, amb TLR2 o TLR4 o sense ells, en el model de lesió medul·lar compressiva severa, no va millorar en cap cas significativament l'activitat locomotriu en comparació amb els animals no trasplantats. No obstant això, el trasplantament de NPC en animals mancats de TLR4 -la capacitat de regeneració dels quals espontània està molt limitada- millora la preservació de fibres neuronals en l'epicentre de la lesió.

En el capítol 3 es descriu el paper de TLR4 en la modulació del fenotip inflamatori dels macròfags en resposta a CSPG emprant un inhibidor específic d'aquest receptor i macròfags procedents de ratolins mancats d'aquest. Els resultats indiquen que els CSPG indueixen un fenotip proinflamatori en macròfags M2 o antiinflamatoris, mediat per TLR4, ja que l'absència tant de l'activitat com de la seua expressió impedeix la inducció de IL1 $\beta$, TNFa o iNOS en presència de CSPGs.

En conclusió, podem afirmar que TLR2 i TLR4 posseeixen un paper rellevant durant la maduració i identitat cel·lular dels NPC en medul·la espinal neonatal sana. Després d'una lesió medul·lar, en l'individu adult, tots dos receptors influeixen positivament en la seua regeneració espontània, no obstant això, la presència de TLR4 podria limitar la capacitat neuroprotectora després d'un trasplantament de NPC de 
manera ectòpica i contribuir a estendre i mantindre les respostes pro-inflamatòries. És per tot això que, l'estudi més detallat del paper de TLR2 i TLR4 i la seua contribució després d'una lesió medul-lar podria contribuir a esclarir mecanismes relacionats amb la seua inducció i resolució, constituint a més una potencial diana de treball en les estratègies de teràpia, inclosa la teràpia cel·lular basada en l'ús de NPC. 


\section{SUMMARY}

Toll-like receptors, TLRs, are key receptors in the defence against pathogens capable of initiating the innate immune response to protect the host. Their role is not only limited to responding to foreign stimuli, but they can also detect damage to injured tissues or cells, inducing their response to what is known as 'sterile inflammation'. Immune system cells are not the only cells that display TLRs; they are also found in glial cells, neurons and neural precursors cells (NPCs). TLR2 and TLR4 NPCs from brain contribute to cell fate determination and neuronal plasticity. However, their roles in spinal cord pathophysiology and in critical processes such as neurogenesis, self-renewal or proliferation are not well defined. This doctoral thesis, distributed among three chapters, has focused: 1) on the study of the role of TLR2 and TLR4 in neonatal spinal cord-derived precursors (Chapter 1); 2) on evaluating the role of both TLR2 and TLR4 in the process of spontaneous regeneration or after ectopic transplantation of NPC, in a model of induced spinal cord injury (Chapter 2); 3) to study the role of TLR4 in modulating the inflammatory phenotype in response to chondroitin sulphate proteoglycan (CSPG) secreted after spinal cord injury with inhibitory activity on axonal regrowth after spinal cord injury (Chapter 3).

In chapter 1, using neonatal mice deficient for TLR2 or TLR4, the relevance of both receptors in the maintenance of the 
SOX2-positive neural precursor population in the neonatal spinal cord is described. Furthermore, TLR2 expression limits their proliferation and self-renewal capacity favouring neural differentiation, while TLR4 expression limits it, possibly mediated through the differential expression of Neurogenin1. Both receptors are required for the maturation of oligodendrocyte precursors.

In chapter 2, the influence of TLR2 and TLR4 on both spontaneous regeneration after spinal cord injury and tolerance in terms of survival and integration to neural precursor transplantation is assessed. The absence of TLR4 results in a significant deficit in spontaneous regeneration of locomotor ability compared to wild type animals. The absence of TLR4 significantly decreases the preservation of neural tracts at the epicentre of the lesion and the absence of TLR2 results in a larger lesion area. In the study of the role of TLR2 and TLR4 in transplanted NPCs after spinal cord injury, we found that NPCs lacking TLR4 confer better preservation of neuronal fibres in the region caudal to the lesion, with a significant increase in BDNF expression. However, transplantation of NPCs lacking TLR2 generates a larger lesion area with increased STAT3 expression. On the other hand, transplantation of NPCs, with or without TLR2 or TLR4, in the severe compressive spinal cord injury model did not significantly improve locomotor activity in any case compared to nontransplanted animals. However, NPC transplantation in animals lacking TLR4 - whose capacity for spontaneous regeneration is 
severely limited - improves the preservation of neuronal fibres at the epicentre of the injury.

Chapter 3 describes the role of TLR4 in modulating the inflammatory phenotype of macrophages in response to CSPG using a specific inhibitor of this receptor and macrophages from mice lacking TLR4. The results indicate that CSPGs induce a proinflammatory phenotype in M2 or anti-inflammatory macrophages, mediated by TLR4, since the absence of their activity and expression prevent the induction of IL1 $\beta$, TNF $\alpha$ or iNOS in the presence of CSPGs.

To conclude, we can assert that TLR2 and TLR4 play a relevant role during the maturation and cellular identity of NPCs in healthy neonatal spinal cord. After spinal cord injury, in the adult individual, both receptors positively influence in spontaneous regeneration; however, the presence of TLR4 could limit the neuroprotective capacity after ectopic NPC transplantation and contribute to extend and maintain pro-inflammatory responses. Therefore, further study of the role of TLR2 and TLR4 and their contribution after spinal cord injury may help to elucidate mechanisms related to their induction and resolution, and may also constitute a potential target for therapy strategies, including cell therapy based on the use of NPCs. 


\section{Acronyms}

ALS

ANOVA

AP-1

ARG1

ATP

BCL2

BCA

BCR

BMS

CCL

CD

CLR

CNS

$\mathrm{CNTF}$

$\mathrm{CO} 2$

COX

$\mathrm{CpG}$

CSPG

CXCL

DAMPS
Amyotrophic Lateral Sclerosis

Analysis of Variance

Activator Protein

Arginase

Adenosine Triphosphate

B-cell lymphoma 2

Bicinchoninic acid assay

B cell Receptor

Basso Mouse Scale

Chemokine (C-C motif) ligand

Cluster of Differentiation

C-type lectin receptors

Central Nervous System

Ciliary Neurotrophic Factor

Carbon Dioxide

Cyclooxygenase

C-phosphate-G

Chondroitin sulphate proteoglycans

$\mathrm{C}-\mathrm{X}-\mathrm{C}$ motif chemokine ligand

Damage-Associated Molecular Patterns 
DAPI

DCX

DLX

DMEM

DNA

ECM

ED1

EDTA

EGF

ERK

FBS

FGF

FOXJ1

FoxO

Fw

GAPDH

GDNF

GFAP

GFP

HMGB 1

HRP

HSP 4',6-diamidino-2-phenylindole

Doublecortin

Distal-Less Homeobox

Dulbecco’s Modified Eagle Medium

Deoxyribonucleic Acid

Extracellular Matrix

Ectodermal Dysplasia

Ethylenediamine Tetraacetic Acid

Ependymal Growth Factor

Extracellular Signal-Regulated Kinase

Fetal Bovine Serum

Fibroblast Growth Factor

Forkhead Box J1

Forkhead Box O

Forward

Glyceraldehyde-3-phosphate dehydrogenase

Glial cell-Derived Neurotrophic Factor

Glial fibrillary acidic protein

Green Fluorescent Protein

High Mobility Group Box 1 protein

Horseradish peroxidase

Heat Shock Protein 
$\mathrm{I} / \mathrm{R}$

Iba1

IFN

IL

iNOS

IRAK

IRF

JAK

JNK

LBP

LIF

LPS

LRR

LV

MAP

MAPK

MBL

MD2

MDA

MHC

MYD

NCAM

NEUROG
Ischemia/Reperfusion

Ionized calcium-binding adapter molecule 1

Interferon

Interleukin

Inducible Nitric Oxide Synthase

Interleukin-1 Receptor-Associated Kinase

Interferon Regulatory Factor

Janus Kinase

c-Jun N-terminal kinase

Lipopolysaccharide-Binding Protein

Leukemia Inhibitory Factor

Lipopolysaccharide

Leucine-Rich Repeat

Lentivirus

Microtubule associated protein

Mitogen-Activated Protein Kinase

Mannan-Binding Leptin

Myeloid Differentiation Factor 2

Melanoma Differentiation-Associated

Major histocompatibility complex

Myeloid Differentiation Primary Response

Neural Cell Adhesion Molecule

Neurogenin 
$\mathrm{NF} \kappa \mathrm{B}$

NG2

NLR

NLRP

NMDA

NOD:

NPC

ODN

Olig

OPC

P-

$\mathrm{P} / \mathrm{S}$

PAGE

PAMPs

PB

PBS

PCR

PDGFR

PFA

PNS

Poly I:C
Nuclear Factor kappa-light-chain-enhancer of activated $B$ cells

Neural/glial antigen

NOD-like receptors

Nucleotide-binding oligomerization domain, Leucine rich Repeat and Pyrin domain containing

N-methyl-D-aspartate

Nucleotide-Binding Oligomerization

Neural Progenitor Cell

Oligodeoxynucleotide

Oligodendrocyte transcription factor

Oligodendrocyte Precursor Cell

Phosphorylated

Penicillin /Streptomycin

Polyacrylamide gel electrophoresis

Pathogen-Associated Molecular Patterns

Phosphate Buffer

Phosphate-buffered Saline

Polymerase Chain Reaction

Platelet-derived growth factor receptor

Paraformaldehyde

Peripheral Nervous System

Polyinosinic:Polycytidylic acid 
PPIA

PRR

PVDF

RIG-I

RLR

RNA

ROS

$\mathrm{Rv}$

SDS

SCI

SGZ

SOX

STAT

SVZ

TCR

TFG

TIR

TIRAP

TLR

TLR2/4 ${ }^{-/-}$

TNF

TRAF
Peptidyl-prolyl cis-trans isomerase A

Pattern recognition receptors

Polyvinylidene difluoride

Retinoic acid-inducible gene I

RIG-like Receptor

Ribonucleic Acid

Reactive oxygen species

Reverse

Sodium dodecyl

Spinal Cord Injury

Subgranular Zone

SRY-related high-mobility-group box

Signal Transducer and Activator of

Transcription

Subventricular Zone

T-cell Receptor

Transforming Growth Factor

Toll/Interleukin-1 Receptor

TIR domain- containing adapter protein

Toll-like Receptor

Deficient for TLR2 or TLR4

Tumour Necrosis Factor

TNF Receptor-Associated Factor 
TRAM

TRIF

VEGF

WT
TRIF-related adapter molecule

TIR-domain-containing adapter-inducing interferon- $\beta$

Vascular Endothelial Growth Factor

Wild Type 


\section{INDEX}

GENERAL INTRODUCTION …..............................................

1. ADAPTATIVE AND INNATE IMMUNE SYSTEM: a set of

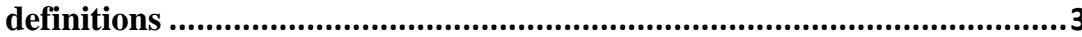

2. TOLL-LIKE RECEPTORS (TLRS): RECEPTORS WITH A

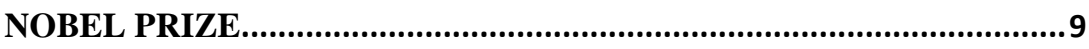

2.1. TLR Family Members …........................................................ 9

2.2. TLR activation and signalling pathways.................................... 13

2.3. Re-defining the Main Role of TLRs......................................... 17

2.3.1. TLRs in Cell Fate Determination, Differentiation, and Neural

Plasticity ................................................................................. 18

2.3.2. The Role of TLRs in Neuroinflammation and

Neurodegeneration ........................................................................ 23

2.4. TLR in Spinal Cord Injury .................................................. 28

3. SPINAL CORD INJURY: PATHOPHYSIOLOGY AND CELL

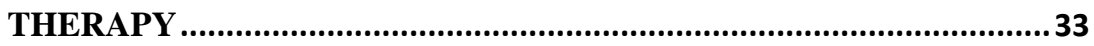

3.1. Pathophysiology of the SCI ..................................................... 35

3.2. Neural Progenitor Cell Transplantation in SCI ........................ 40

HYPOTHESIS AND OBJECTIVES ...................................47

MATERIALS AND METHODS......................................... 51

1. ANIMAL MODELS .................................................................53

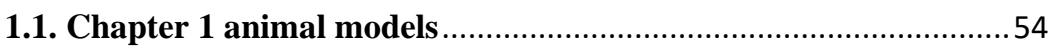

1.2. Chapter 2 animal models ....................................................... 54

1.2.1. Spinal cord compression model..................................56

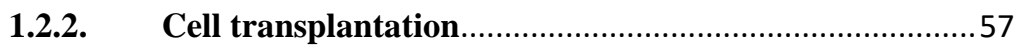

1.2.3. Post-surgery Procedure .................................................... 58

1.2.4. Functional locomotor test ................................................... 59

1.2.5. Tissue Harvest for further histological and molecular analysis

1.3. Chapter 3 animal models

.65 
2. CELL CULTURES....................................................................65 65

2.1. Bone Marrow-derived macrophages (BMDMs) .........................65

2.1.1. BMDM polarization..............................................................66

2.2. Neonatal microglial cell and Astrocytes from mixed cultures.....67

2.3. Adult microglial cell culture......................................................68

2.4. Neural Progenitor Cell Culture ...............................................69

2.4.1. Neurosphere Disaggregation ............................................... 70

2.4.2. Freezing and Thawing ................................................... 70

2.4.3. NPC Culture in adherent conditions .................................... 71

2.4.4. Spontaneous Differentiation of NPC .................................. 71

2.4.5. NPC Population Doubling Analysis .................................... 72

2.4.6. NPC Proliferation Assay by BrdU Incorporation and Ki67

Immune detection .................................................................... 72

2.4.7. NPC Transfection with EGFP-LV …................................. 73

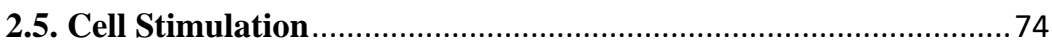

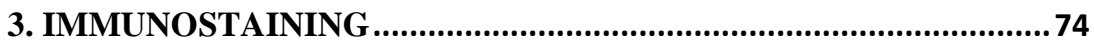

3.1. Sample preparation................................................................. 74

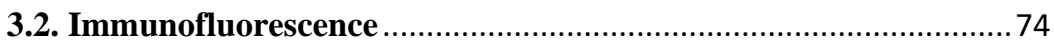

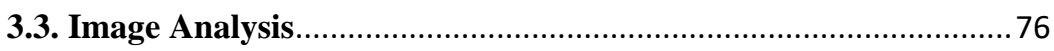

4. RNA ISOLATION, CONVERSION TO CDNA AND QUANTITATIVE

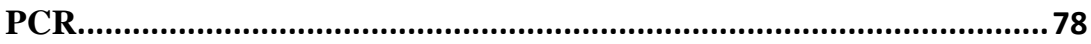

5. WESTERN BLOT: PROTEIN EXTRACTION AND

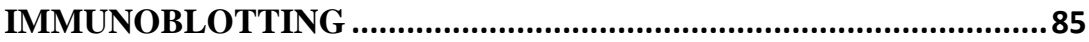

6. MICROSCOPY TECHNIQUES ................................................. 87

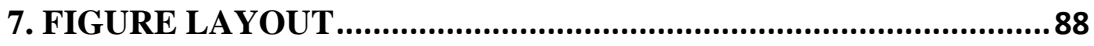

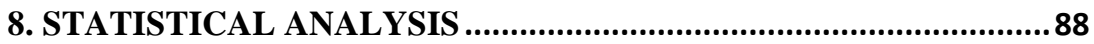

RESULTS

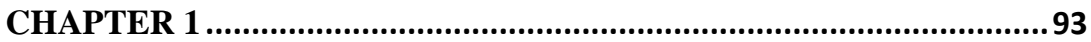

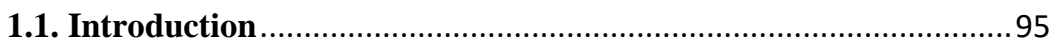

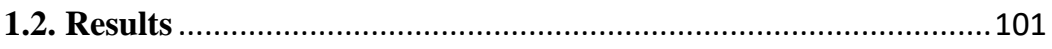


1.2.1. TLR2 and TLR4 Expression Maintain the NPC Population in the Postnatal Mouse Spinal Cord 101

1.2.2. TLR Expression by in vitro-Expanded NPCs Isolated from the Postnatal Mouse Spinal Cord 106

1.2.3. TLR2, but not TLR4, Regulates the Self-renewal of in vitroExpanded NPCs Isolated from the Postnatal Mouse Spinal Cord109 1.2.4. TLR2 and TLR4 in Differentially Contribution to the Formation of Mature Neurons and Glial Cells ........................... 115

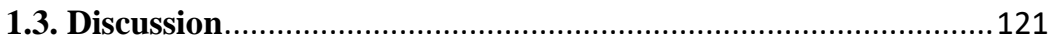

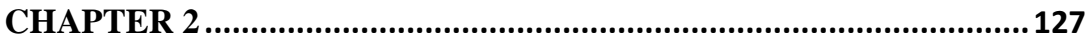

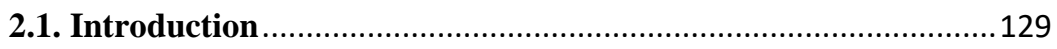

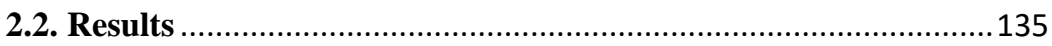

2.2.1. Spontaneous recovery of hind limb function after SCI requires of TLR4

2.2.2. NPC, lacking TLR2 or TLR4, transplantation on functional neurological recovery after SCI.

2.2.3. WT-NPCs partially rescue specific impaired locomotor skills exhausted in TLR4 deficient mice after severe spinal cord compression 162

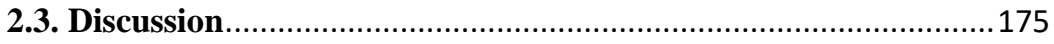

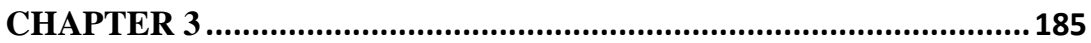

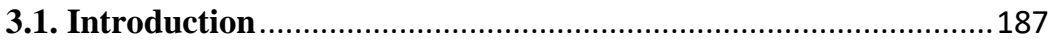

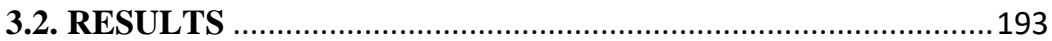

3.2.1. CSPG mediated the phenotypic conversion of BMDM from anti-inflammatory to pro-inflammatory ........................................193

3.2.2. CSPG treatment reverts the anti-inflammatory phenotype in microglial cells in vitro but lees in comparison with BMDM........200 3.2.3. Metabolites derived from BMDMs treated with CSPGs

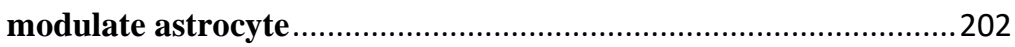

3.2.4. TLR4 pathway is essential to develop the inflammatory phenotype on M2 BMDM.............................................................205

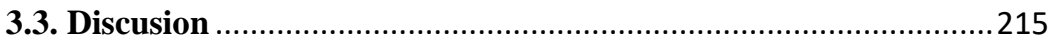

CONCLUSIONS............................................................... 221

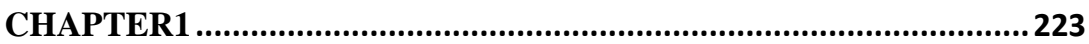




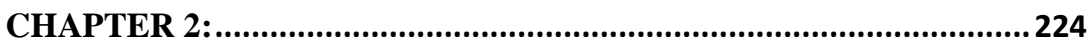

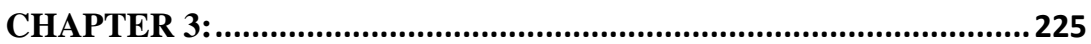

BIBLIOGRAPHICAL REFERENCES .......................... 227

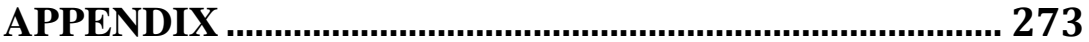




\section{Figure list}

Figure 1. Cells of the innate and adaptive immune system.

Figure 2. Location of Pattern Recognition Receptors

Figure 3. TLR4 Protein Structure

Figure 4. Signaling pathways downstream of TLR4 activation

Figure 5. Schematic model of sequential LPS transport to the TLR4/MD2 complex

Figure 6. Role of TLR on cell fate, differentiation, and neural plasticity

Figure 7. Schematic Representation of Spinal Cord Segments

Figure 8. The pathophysiology of the spinal cord before and after injury

Figure 9. Pathophysiological events and potential therapeutic targets after SCI.

Figure 10. Summary of Animals used in Chapter 2

Figure 11. Chapter 1 Graphical Abstract

Figure 12. TLR2 and TLR4 Expression in the neonatal mouse spinal cord

Figure 13. Analysis of cell fate on Spinal Cord from WT and TLR2 and TLR4 Knockout Mice

Figure 14. TLR2 and TLR4 Expression by in vitro-expanded Spinal Cord NPCs

Figure 15. FOXJ1 and SOX2 positive cells in $\mathrm{CC}$ and neurospheres derived from neonatal mice 
Figure 16. Involvement of TLR 2 and TLR 4 in the Self-renewal of NPCs

Figure 17. TLR2 and TLR4 Loss Influence the Spontaneous Differentiation of in vitro-expanded Spinal Cord NPCs

Figure 18. Dotplot of Pathways Related with the "TLR" GO Term

Figure 19. Chapter 1 Graphical Abstract

Figure 20. Locomotor recovery following spinal cord injury measured by BMS score

Figure 21. Evaluation of locomotor recovery following spinal cord injury by ladder beam test

Figure 22. Both, TLR2 and TLR4 deletion shows stepping coordination deficits by Catwalk gait analysis after SCI

Figure 23. Histological analysis of neural fibres labelled with $\beta$ III-Tubulin

Figure 24. Histological analysis of fibrotic scar by delimitation of the area negative for GFAP staining

\section{Figure 25.}

Western blotting analysis of the protein extracts from rostral $(\mathrm{rSC})$ and caudal (cSC) region of spinal cords

Figure 26. EGFP protein expression in NPC from neonatal mice

Figure 27. Detection and analysis of EGFP-NPC 35 days after transplantation

Figure 28. Locomotor recovery following spinal cord injury by BMS score from WT animals 
Figure 29. Evaluation of locomotor recovery following spinal cord injury by ladder beam test in WT animals

Figure 30. Catwalk Gait Analysis from WT animals after WT or $\mathrm{TLR}^{-/-}$cell transplantation

Figure 31. Histological analysis of neural fibres labelled with $\beta$ III-Tubulin from WT animals with NPC transplanted

Figure 32. Histological analysis of fibrotic scar by delimitation of the area negative for GFAP staining from WT animals with NPC transplanted

\section{Figure 33.}

Western blotting analysis of the protein extracts from rostral (rSC) and caudal (cSC) region of spinal cords from WT animals with NPC transplanted

Figure 34. Locomotor recovery following spinal cord injury measured by BMS score in WT and TLR2 $2^{-/-}$or TLR $4^{-/}$animals with WT-NPCs transplantation

Figure 35. Evaluation of locomotor recovery following spinal cord injury by ladder beam test in WT and TLR2 ${ }^{-/}$or TLR $4^{-/-}$ animals with WT-NPCs transplantation

Figure 36. Catwalk Gait Analysis from WT and TLR2 ${ }^{-/}$or TLR4 '- animals with WT-NPCs transplantation

Figure 37. Histological analysis of neural fibres labelled with $\beta$ III-Tubulin from WT and TLR2 ${ }^{-/-}$or TLR $4^{-/}$animals with WTNPCs transplantation.

Figure 38. Histological analysis of fibrotic scar by delimitation of the area negative for GFAP staining from WT and TLR2 $2^{-/}$or TLR4 $^{-/-}$animals with WT-NPCs transplantation. 
Figure 39. Western blotting analysis of the protein extracts from rostral (rSC) and caudal (cSC) regions of spinal cords from WT, $\mathrm{TLR}^{-/-}$and $\mathrm{TLR}^{-/-}$animals transplanted with WT-NPC transplantation

Figure 40. Chapter 3 graphical abstract

Figure 41. BMDM Polarization into M1 and M2 phenotype

Figure 42. CSPG treatment reverts the anti-inflammatory gene expression of phenotype M2 in BMDM

Figure 43. CSPG treatment reverts the anti-inflammatory phenotype $\mathrm{M} 2$ in BMDM via $\mathrm{P} 38$

Figure 44. CSPG treatment induces pro inflammatory activation of M2 polarized anti-inflammatory microglial cells

Figure 45. Metabolites derived from BMDMs treated with CSPGSs modulate astrocyte phenotype

Figure 46. CSPG proinflammatory effects restored following TLR4 inhibition

Figure 47. BMDM TLR $4^{-/-}$show less proinflammatory phenotype than BMDM from WT mice

Figure 48. BMDM TLR4 ${ }^{-/-}$shows different response to CSPG treatment

Figure 49. WT, TLR2 $2^{-/-}$and TLR $4^{-/-}$mice stepping coordination measured by Catwalk gait analysis before SCI. 


\section{Table list}

Table 1. Classifications of TLRs

Table 2. Scoreboard based on paw movement

Table 3. Scores and operational definitions for BMS for locomotion.

Table 4. Primary antibodies for immunofluorescence assays

Table 5. Sequences of Forward and Reverse primer for Rat genes

Table 6. Sequences of Forward and Reverse primer for Mouse genes

Table 7. Primary antibodies for Western Blot assays 


\section{GENERAL}

\section{INTRODUCTION}




\section{ADAPTATIVE AND INNATE IMMUNE SYSTEM: a set of definitions}

The immune system protects the body from diseases and infections by helping living organisms to adapt to their environment. Organs, multiple cell types, and diverse processes comprise the immune system, which functions to 1) defend the body from pathogens and toxins, 2) control and identify foreign cellular bodies, which may lead to tumors, and 3) maintain tissue homeostasis through the removal of cellular debris. Importantly, the immune system must be able to distinguish between self and non-self to function adequately. Like other mammals, human beings possess innate and adaptive immune systems (see Figure 1) that protect us from external and internal factors. The immune system evolves and improves following exposure to foreign stimuli such as physical injury, a bacterial infection, or even a global pandemic (extensively reviewed in (1)).

The innate immune system represents the first defensive system or barrier that functions to block or eliminate pathogens that come into contact with the body, preventing the spread of infection to adjacent tissues and cells (2). The main cell types involved include monocytes/macrophages, natural killer cells, dendritic cells, mastoid cells, lymphocytes, neutrophils, eosinophils, and basophils. Innate immune system cells have 
specific receptors that interact with highly conserved structures on pathogens. The innate immune system represents a nonspecific defense mechanism, and cells trigger mechanisms to destroy pathogens by phagocytosis (3), complement activity (4), induced toxicity (5) and natural killer cells (6). Overall, the main roles of the innate immune system comprise the identification and removal of foreign stimuli and the activation of the adaptative immune system. In addition, natural killer cells can function as a component of both systems by eliminating detected pathogens by breaking down the damaged cell membrane (6).

The adaptive immune system produces specific responses to each infectious agent and stores immunological memory of the pathogen to prevent reinfection. B and T lymphocytes play vital roles by differentiating between self and non-self through immunoglobulin-based receptors. $\mathrm{B}$ and $\mathrm{T}$ lymphocytes require the formation of specific surface receptors to recognize antigens - BCRs and TCRs, respectively. The response of the adaptive immune system is more complex and precise than the innate immune system response but develops over several days or weeks. The complex mechanisms involved enable associated cells to recognize and present a wide variety of antigens (7). B and $\mathrm{T}$ lymphocytes act after this interaction to allow the generation of immune memory. While T-cells display specific receptors, B-cells secrete specific antibodies as a response to the adaptive immune system (8). 


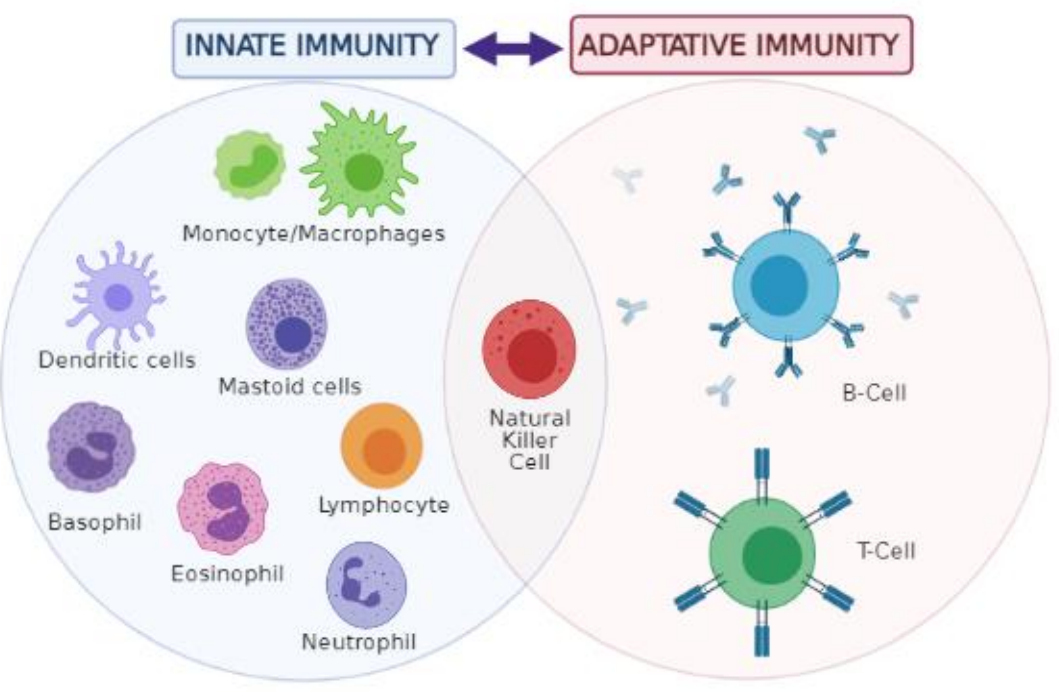

Figure 1. Cells of the innate and adaptive immune system. Image created with the information from (9).

The correct identification and elimination of pathogenic stimuli through the innate immune system requires an adaptive immune system response. The innate immune system possesses proteins that act as receptors or transducers of pathogenic stimuli, which include pattern recognition receptors (PRR) (10), which have been evolutionarily selected as the main recognisers of 1) bacterial structures or molecules that cause infections(pathogenassociated molecular patterns or PAMPs) (11), and 2) endogenous cell damage structures or signals(damage-associated molecular patterns or DAMPs) (12).

PAMPS and DAMPS are molecules of different nature/chemical compositions and include proteins, DNA, RNA, and metabolites. PAMPS derive from the pathogenic 
microorganisms that trigger infections in the body (13) with lipopolysaccharide (LPS) of gram-negative bacteria the first identified PAMP. DAMPS are released by cells/tissues in response to tissue damage or inflammation (14); however, PAMPs and DAMPS can activate the immune response via the same PRR.

Overall, the PRRs are classified into four distinct families:

The nucleotide-binding oligomerization-like receptors or NOD-like receptors (NLRs) are cytoplasmic proteins that recognize bacterial peptidoglycans and mount pro-inflammatory and antimicrobial immune responses (15). Approximately twenty NLR genes are found in the mammalian genome (including the nucleotide-binding oligomerization domain genes - NOD1-20) and code for nucleoside triphosphate-binding proteins (16). The activation of the most well-known NLR proteins - NOD1 and NOD2 (Figure 2) - induces the nuclear translocation of the nuclear factor kappa beta $(\mathrm{NF \kappa B})$ transcription factor to activate the expression of pro-inflammatory cytokines (17) (Figure 4).

The Retinoic acid-inducible Gene-I-like receptors (RLRs) are cytoplasmic proteins involved in the recognition of viruses by the innate immune system (18), with RIG-1 the best-characterized receptor (19). RLR signaling depends on binding to the mitochondrial antiviral signaling protein, which then supports the nuclear translocation of interferon regulatory 
factor (IRF) 3 and 7 and the induction of interferon (IFN-) type I and type III activity through the activity of tumor necrosis factor receptor-associated factor 3 (TRAF3) (Figure 2 and 4). Additionally, melanoma differentiation-associated 5 (MDA5) (20) and RIG-I-like receptor LGP2 (21) help to provide the frontline defense against viral infections in most tissues.

C-type lectin receptors (CLRs) are a family of surface receptors that include collectins, pentraxins, selectins, dectins, and mannose receptors. CLRs are the primary receptors used for the recognition of fungi-derived factors. The mannose receptors, PRRs primarily present on the surface of macrophages and dendritic cells, bind to repeating mannose units present on pathogen surfaces and trigger endocytosis and phagocytosis of the pathogen via the complement system (22). Specifically, binding to mannose triggers the recruitment of mannan-binding leptin (MBL)-associated serine proteases that activate the complement cascade, thereby amplifying the immune response (23).

The Toll-like receptors (TLRs) are type I transmembrane receptors that comprise an extracellular domain for the recognition of infectious agents and an intracellular domain with homology to the interleukin (IL-)1 receptor. TLRs recognize bacterial lipids and DNA, viral RNA, and various proteins deriving from pathogenic microorganisms and are the primary receptors of the innate immune system (24). 


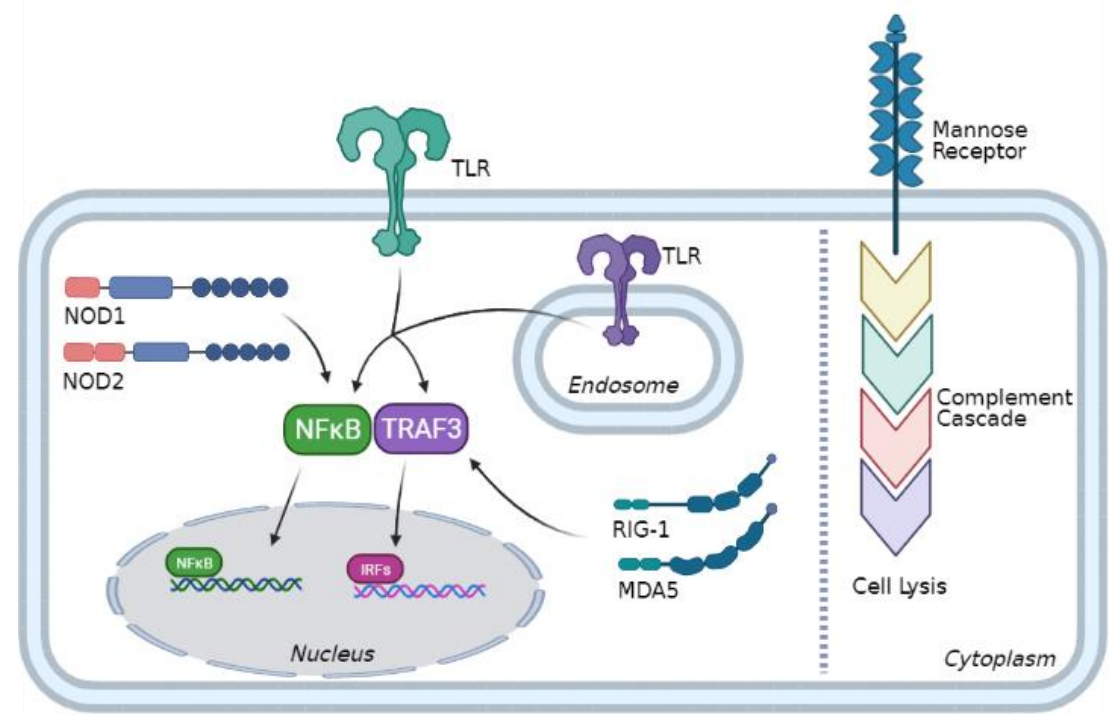

Figure 2. Location of Pattern Recognition Receptors. NLRs (NOD1 and NOD2) and RLRs (RIG1 and MDA5) are cytoplasmic receptors. TLRs and CLRs (such as the mannose receptor) are transmembrane receptors located both in the plasma membrane and endosomal membranes in the case of TLR3,7, 8, 9, and 12. The mannose receptor activates the complement cascade; TLR and NOD1-2 promote the translocation of NFKB to the nucleus; RLR and TLR promote IRF translocation to the nucleus through TRAF3 to modulate inflammatory responses. Image created from the information from (18). 


\section{TOLL-LIKE RECEPTORS (TLRs): RECEPTORS WITH A NOBEL PRIZE}

The Toll protein was first identified in 1985 in the fruit fly Drosophila melanogaster as a factor required to establish dorsoventral polarity in the developing embryo (25). However, Toll was only identified as an essential part of the innate immune system in 1996, where they respond to bacterial and fungal infections (26). The discovery of TLRs by the research group of Jules Hoffman in 1996 and the description of their crucial role in the defense against bacterial pathogens gained the Nobel Prize in Physiology or Medicine in 2011 for their discoveries concerning the activation of innate immunity together with Bruce A. Beutler (27) .

TIL (now TLR1) was the first receptor identified in human cells (28), and the second, hTOLL (now TLR4), induces the activation of $\mathrm{NF} \kappa \mathrm{B}$ and the expression of IL and NFKB-controlled genes (29).

\subsection{TLR Family Members}

Members of the TLR family of transmembrane glycoproteins are subdivided into cell surface (TLR 1, 2, 4, 5, and 6) and intracellular (TLR3, 7/8, and 9) receptors (Table 1). Each member possesses an extracellular domain with the leucine-rich 
repeat (LRR) motif, a transmembrane helix domain, and an intracellular domain homologous to the IL-1 receptor (Toll/receptor-IL1: TIR) (Figure 3 depicts the structure of TLR4 as an example). The extracellular region displays a horseshoe-like structure, which allows the ligand to interact with the TLR (30). Ligand binding promotes the dimerization of TIR domains to allow interactions with adapters such as myeloid differentiation primary response 88 (MyD88) or TIR-domain-containing adapter-inducing interferon- $\beta$ (TRIF) to activate transcription factors that trigger the expression of inflammatory genes response (31). Table 1 describes the different adapters through which TLRs intracellularly signal. Of the thirteen members of the TLR family currently known, TLRs 1 to 11 are conserved between humans and mice, although TLR10 is a pseudogene with no known function in mice; furthermore, TLR12 and 13 function in mice but are inactive pseudogenes in humans (32).

A)

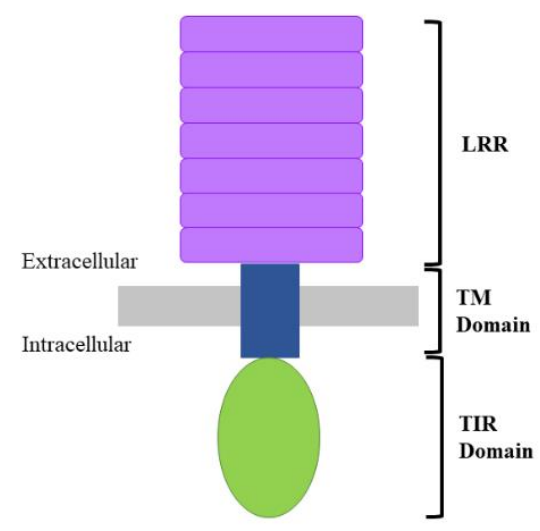

B)

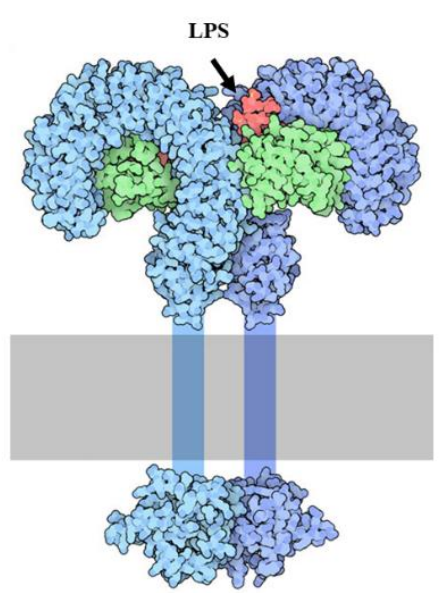


Figure 3. TLR4 Protein Structure. A) LRR (purple): Leucine Rich Regions; TM: Transmembrane Region (blue); TIR domain (green): Cytoplasmic IL1/Toll Receptor Domain. B) Schematic based on the crystallization of TLR4 homodimer. LPS ligand binding (in red) promotes dimerization of the TIR domains of TLR4 monomers (blue). 
Table 1. Classifications of TLRs. Table information extracted from (33-35).

\begin{tabular}{|c|c|c|c|c|}
\hline$T L R$ & Ligal & ${ }_{D A M P}$ & Location & Adapter \\
\hline$T L R 1$ & Triacyl lipopeptides & N/A & Cell surface & MYD88/TIRAP \\
\hline$T L R 2$ & $\begin{array}{c}\text { Triacyl lipopeptides } \\
\text { Diacyl lipopeptides } \\
\text { Lipoteichoic acid } \\
\text { Zymosan } \\
\beta \text {-Glucan }\end{array}$ & $\begin{array}{l}\text { HSPs }(60,70) \\
\text { Fibronectin } \\
\text { Versican } \\
\text { Glycoprotein } 96 \\
\text { Hyaluronic acid } \\
\text { Fibrinogen } \\
\text { Heparan sulfate }\end{array}$ & Cell surface & MYD88/TIRAP \\
\hline$T L R 3$ & dsRNA & dsRNA & $\begin{array}{l}\text { Endosome } \\
\text { surface }\end{array}$ & TRIF \\
\hline TLR4 & $\begin{array}{l}\text { Lipopolysaccharide } \\
\text { RSV F-protein }\end{array}$ & $\begin{array}{c}\text { HSPs }(22,60,70, \\
72) \\
\text { HMGB1 } \\
\text { Glycoprotein } 96 \\
\text { Oxided } \\
\text { phospholipids } \\
\text { Fibronectin } \\
\text { Tenascin C } \\
\beta \text {-Defensin } 2 \\
\text { Versican } \\
\text { Hyaluronic acid } \\
\text { Fibrinogen } \\
\text { Heparan sulfate }\end{array}$ & Cell surface & $\begin{array}{c}\text { MYD88/TIRAP } \\
\text { TRIF/TRAM }\end{array}$ \\
\hline TLR5 & Flagellin & N/A & Cell surface & MYD88 \\
\hline TLR6 & $\begin{array}{c}\text { Triacyl lipopeptides } \\
\text { Diacyl lipopeptides } \\
\text { Lipoteichoic acid } \\
\text { Zymosan }\end{array}$ & N/A & Cell surface & MYD88/TIRAP \\
\hline$T L R 7$ & $\begin{array}{c}\text { ssRNA } \\
\text { Imidazoquinoline }\end{array}$ & $\begin{array}{l}\text { ssRNA (immune } \\
\text { complex) }\end{array}$ & $\begin{array}{l}\text { Endosome } \\
\text { surface }\end{array}$ & MYD88 \\
\hline TLR8 & $\begin{array}{c}\text { ssRNA } \\
\text { Imidazoquinoline }\end{array}$ & $\begin{array}{l}\text { ssRNA (immune } \\
\text { complex) }\end{array}$ & $\begin{array}{l}\text { Endosome } \\
\text { surface }\end{array}$ & MYD88 \\
\hline TLR9 & $\begin{array}{c}\text { CpG DNA } \\
\text { dsDNA virus (Herpex } \\
\text { virus) } \\
\text { Hemzoin }\end{array}$ & DNA & Endosome & MYD88 \\
\hline TLR10 & $\begin{array}{c}\text { Triacylated } \\
\text { lipopeptides }\end{array}$ & N/A & Cell surface & MYD88 \\
\hline TLR11 & $\begin{array}{c}\text { Profilin-like molecule } \\
\text { Uropathogenic } \\
\text { bacteria }\end{array}$ & N/A & Cell surface & MYD88 \\
\hline TLR12 & N/A & N/A & $\begin{array}{l}\text { Endosome } \\
\text { surface }\end{array}$ & MYD88 \\
\hline TLR13 & N/A & N/A & N/A & MYD88 \\
\hline
\end{tabular}


dsRNA - double-stranded RNA; ssRNA - single-stranded RNA; CpG RNA: shorthand for 5'-C-phosphate-G-3', that is, cytosine and guanine separated by only one phosphate group; HSP: heat shock protein; HMGB1: high-mobility group protein 1. N/A: not available.

\subsection{TLR activation and signalling pathways}

TLR activation begins with the binding of the ligand to the extracellular LRR-rich domain, which promotes binding between the TIR domains of each monomer, thereby promoting TLR dimerization. TLRs can form homodimers, as in the case of TLR4, or heterodimers, as in the case of TLR2 (which dimerizes with TLR1 or TLR6). The MYD88 or TRIF TIR domaincontaining adaptor proteins are then recruited to the TIR domain to activate downstream signaling cascades $(11,24)$. Depending on the adaptor protein, TLRs function through MYD88-dependent or MYD88-independent/TRIF dependent signaling pathways.

The MYD88-dependent pathway (Figure 4, blue lines, showing TLR4 activation) recruits and activates interleukin-1 receptor-associated kinase (IRAK)4, which hyperphosphorylates IRAK-1, and forms a complex with tumor necrosis factor receptor-associated factor (TRAF) 6. TRAF6 drives the activation of the mitogen-activated protein kinase (MAPK), TAK1 (36), which then activates two different pathways. TAK1 can bind to the IKK complex and phosphorylates and activates the IKK $\beta$ component, which then induces the release and nuclear translocation of NFאB. TAK1 can 
also activate the MAPK signaling pathways (involving ERK1/2, $\mathrm{p} 38$, and JNK), with the final result the activation and nuclear translocation of the AP-1 transcription factor (reviewed in (37)).

TRIF-dependent or MYD88-independent pathways (Figure 4, red lines, showing TLR4 activation) also involve the activation of TRAF6, which recruits the RIP1 kinase. The RIP1 kinase then activates the TAK1 complex, which subsequently activates the NFKB and MAPK pathways (31) as previously described for the MYD88-dependent pathway. Meanwhile, TRAF3 activation leads to the recruitment of IKK $\varepsilon$ to induce the phosphorylation of IRF3, which dimerizes and translocates into the nucleus. TRAF6 and TRAF3 complexes can also induce the phosphorylation, dimerization, and nuclear translocation of IRF7 (38).

All TLRs activate the MYD88-dependent signaling pathway except TLR3, which activates the TRIF-dependent pathway; however, TLR4 can activate both signaling pathways. Both pathways activate a cascade of molecular reactions that culminates in the activation and nuclear translocation of the NFкB, AP-1, or IRF transcription factors, which activate the expression of genes associated with the inflammatory response. Such genes include inducible nitric oxide synthase (iNOS), Cycloxygenase-2 (COX2), RANTES, and various interleukins and interferons (39). 


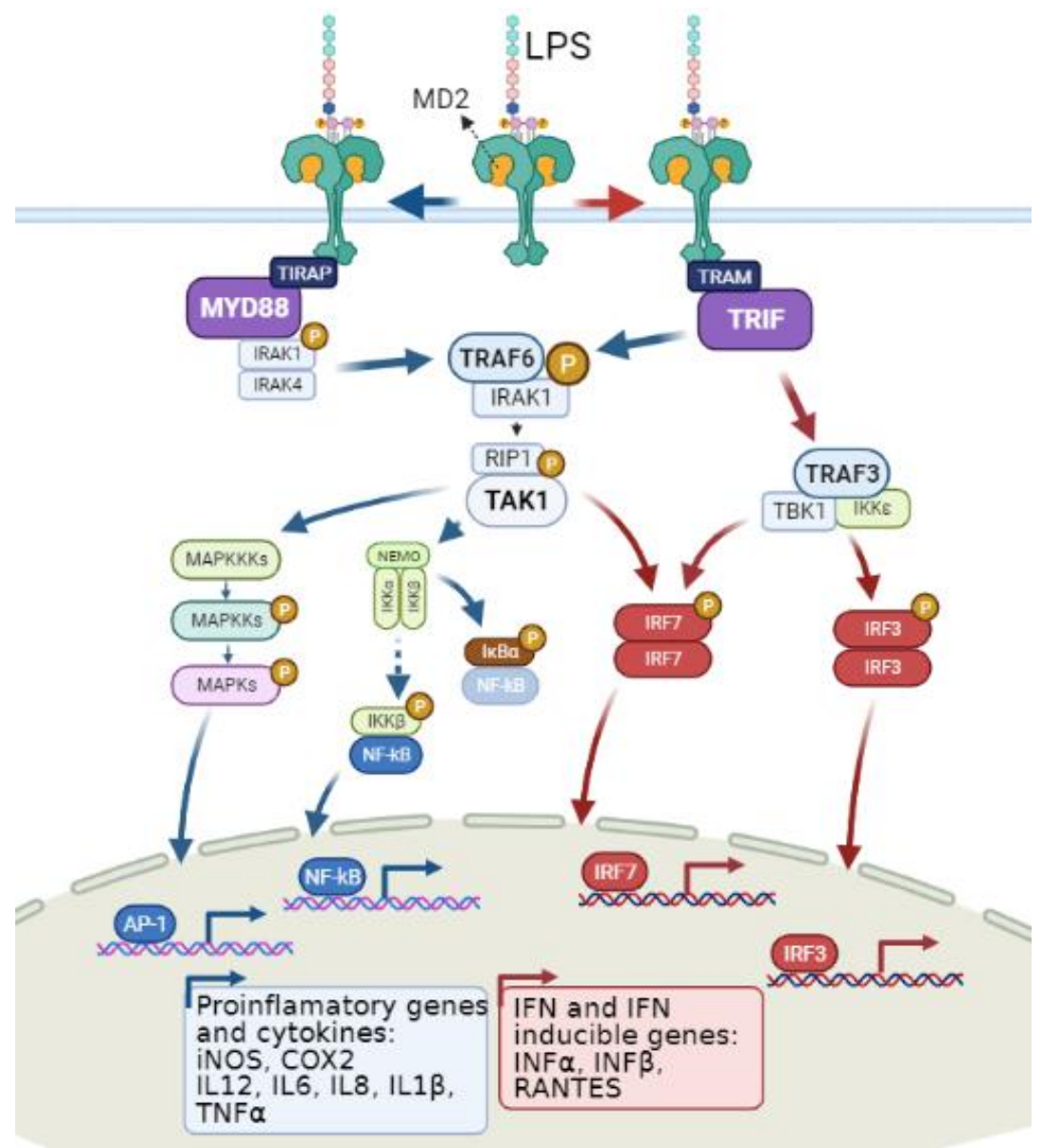

Figure 4. Signaling pathways downstream of TLR4 activation. Ligand recognition by TLR4 (LPS in this case) leads to the recruitment of MYD88 or TRIF with the collaboration of adaptors proteins TIRAP and TRAM, respectively. The figure shows the activation of the MYD88-dependent pathway in blue, which culminates in the activation of pro-inflammatory genes, and the activation of the TRIF-dependent pathway in red, which culminates in the activation of IFN-inducible genes. Image created from the information of $(40,41)$.

LPS, the primary ligand of TLR4, forms aggregates in aqueous solutions due to the presence of hydrophobic multi-acyl 
chains. Therefore, TLR4 requires co-receptors and accessory proteins to recognize LPS. First, TLR4 uses the co-receptor Myeloid differentiation factor 2 (MD2) to physically bring the cytosolic TIR domains of TLR4 into close enough proximity to recruit downstream adaptor molecules. In addition, accessory proteins such as lipopolysaccharide-binding protein (LBP) and CD14 enhance recognition of LPS. The N-terminal tip of LBP binds to LPS micelles (Figure 5, Step 1), and the concave surface in the C-termini al domain of CD14 interacts with the C-terminal tip of LBP to transfer a single LPS molecule to CD14 (Figure 5, Step 2). The LPS-bound CD14 is rapidly dissociated from the LBP due to electrostatic repulsion, and another CD14 binds to LBP (Figure 5, Step 3). CD14/LPS then interacts with the LRR13-15 domains of TLR4 to transfer LPS to TLR4/MD2 and induce dimerization (Figure 5, Step 4) (42).

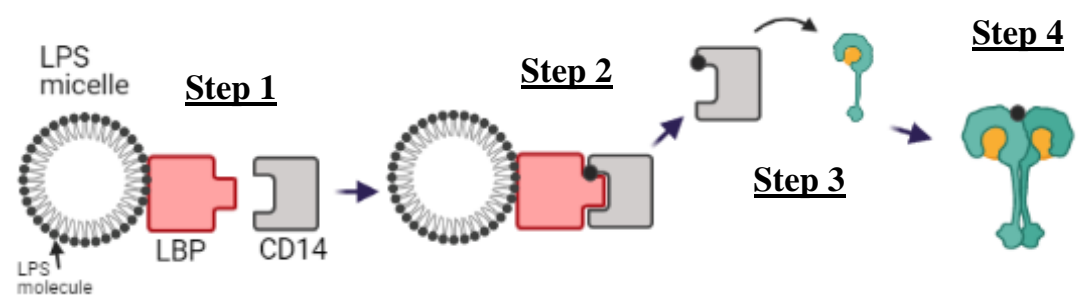

Figure 5. Schematic model of sequential LPS transport to the TLR4/MD2 complex. Image adapted from Kim et al. (42). 


\subsection{Re-defining the Main Role of TLRs}

Cells of the immune system use TLRs to defend against foreign stimuli causing infections; however, non-immune cells also express TLRs, which play different roles. The work carried out in this thesis focuses on the role of TLRs in cells of the central nervous system (CNS), specifically in spinal cord cells.

\section{Neuronal TLR expression}

TLRs are expressed in primary cultures of human (43), mouse (44) and rat (45) neurons in both CNS (46) and peripheral nervous system (PNS) (45). TLR1-TLR9 mRNA and TLR2, TLR3, TLR4, and TLR6 protein have been detected in neurons $(43,44,46,47)$ at the embryonic $(47,48)$, postnatal $(49)$, young (45) and adult $(45,50)$ stages.

\section{Glial TLR expression}

Glial cells primarily function in immune surveillance (microglia), the regulation of the biochemical environment (astrocytes), and the production of the myelin sheath (oligodendrocytes in CNS; Schwann Cells in PNS), and are required for proper neural function (51).

Microglia form the immune barrier in the CNS (52) and express TLR1-TLR5 and TLR7-TLR9 in addition to the coreceptor CD14 $(53,54)$. Astrocytes support and guide neural 
connections and maintain the homeostasis of oligodendrocytes, neurons, and immune system cells (55). Astrocytes express TLR1-9 in mice and TLR1, 3, 4, 5, and 9 in humans $(56,57)$. TLR3 is highly expressed in rodents and humans and becomes significantly increased in response to pathological processes such as viral infections (58). Oligodendrocytes and Schwann cells produce the myelin sheath around axons in the CNS $(34,59)$ and PNS, respectively (60-62). Schwann cells express TLR1-9 in mice (61), TLR4 in rats (60), and TLR2 in humans (62). Although only TLR2 and TLR3 have been detected in oligodendrocytes in humans and rats $(34,59)$, microglial TLR4 signaling promotes the generation of oligodendrocytes by upregulating ciliary neurotrophic factor (63).

\section{Neural Stem/Progenitor Cells Expression}

Neural progenitors cells (NPC) are multipotent cells with the capacity to differentiate into neural and glial lineages present in both the brain $(56,57)$ and spinal cord $(64)$. TLR1-9 gene expression has been identified in NPC-derived from mouse hippocampal (65).

\subsubsection{TLRs in Cell Fate Determination, Differentiation, and Neural Plasticity}

As first described in Drosophila, an additional function ascribed for TLRs relates to cell determination, specifically regulating the embryonic dorsoventral polarity in organ 
specification and subsequent developmental biology $(26,66)$. A variety of additional developmental functions have been ascribed to the Drosophila Toll receptors, including synapse formation in olfactory neurons (67) and the recognition of neurotrophins to control neuronal survival and death (68). Furthermore, TLRs expressed in non-immune tissues also regulate development, cell fate, cell number, neural circuit connectivity, and synaptogenesis in various mammalian species (69).

In Drosophila, the cleavage of Spz proteins, which are essential for the early development of the embryo, activates Toll proteins (Toll-1, -2, -3, -8, and -9) in the ventral area, which allows the signaling cascade to unblock the degradation of Cactus proteins, IKK $\beta$-complex that forms with Dorsal protein (70). The translocation of Cactus forms a gradient along the ventral half of the embryo to activate proteins crucial for embryo development, such as Snail, Twist, and Rhomboid, which forms the dorsoventral partition (71). The activation of TLR proteins in later stages permits the activation of pathways necessary for the correct development of the neural tube in the ventral part of the embryo and the heart in the dorsal part of the embryo.

Focusing on neural plasticity, TLR8 and TLR6 promote the growth of the glutamatergic neuromuscular junction in Drosophila through JNK (72) and JNK/FoxO, respectively, by causing microtubule destabilization to form new synaptic buttons (73). Interestingly, knock-out of TLR8 and 6 in Drosophila 
reduces the number of motoneurons and synaptic connections, thereby causing a slow-crawling phenotype in affected larvae.

In Caenorhabditis elegans, a widely employed model in neuroscience, the Brandt group demonstrated that signaling through the TOL1 protein, the sole TLR of C. elegans, mediates neural differentiation and determines neuronal cell fate. TOL1 is expressed in BAG neurons, which are sensitive to $\mathrm{CO}_{2}$ changes, and TOL1 signaling through TRAF, IRAK, and IKK $\beta$ regulates the correct differentiation of these neurons (74). In addition, TOL1 activates an alternative transcription factor that controls cell fate determination in the absence of the NFאB pathway (75). There is no evidence for TLRs' involvement in neural plasticity in $C$. elegans; however, signaling adapters such as TIR-1 have been associated with synapse formation mechanisms linked to right-left asymmetry (76).

Rolls and collaborators described how TLR proteins regulate both the proliferation and neuronal differentiation of NPCs in the subgranular area of the hippocampus of adult mice (65). They reported the essential nature of TLR2 for the proper differentiation into neurons, as its absence limited neurogenesis in the adult hippocampus. The absence of TLR2 in NPCs directed differentiation into astrocytes, while TLR2 overexpression resulted in the overproduction of neurons. In the same study, the authors established that the absence of TLR4 increased neurogenesis. TLR2 activation with DAMPS such as hyaluronic 
acid blocks the maturation and re-myelination activity of oligodendrocytes precursor cells (OPC) (77) and inhibits the proliferation of embryonic neural progenitors (78). In retinal neural progenitors, activation of TLR4 restricts proliferation (79). Additionally, the activation of TLR4 in NPCs through LPS exposure leads to the differentiation of neurons and oligodendrocytes and their increased survival; however, treatment with a TLR4 antagonist promoted cell death and apoptosis (80).

A recent study by Lathia et al. discovered a role for TLR3 in the proliferation of mouse embryonic NPCs; overall, TLR3 acted as a negative regulator of NPC proliferation in the embryonic cortex and controlled the proper development of CNS through differential expression during distinct embryonic stages (81). In primary neurons, TLR3 stimulation inhibits neurite outgrowth and causes irreversible growth cone collapse without affecting cell survival (44); however, TLR3-deficient mice display alterations in structural plasticity and suffer from impaired spatial recognition and contextual memory (82). TLR8 displays differential expression during the early stages of brain development in Drosophila; specifically, TLR8 expression increases between embryonic day twelve and postnatal day one and decreases after postnatal day seven (46). TLR8 overexpression in neurons induces neuronal apoptosis and inhibits neurite outgrowth (83). 
Cell fate and Differentiation

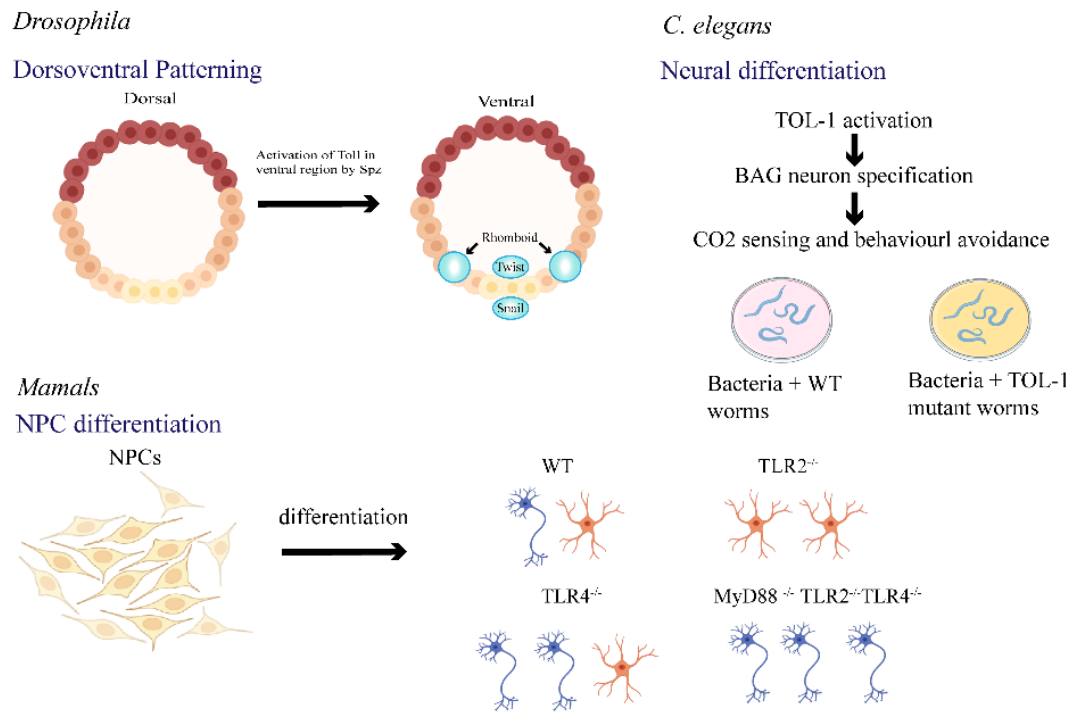

Neural plasticity

Drosophila

Glutamatergic neuromuscular junction

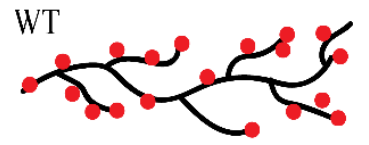

$\mathrm{TLR}^{-1-}$ or TLR8 ${ }^{--}$

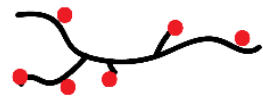

Sinaptic Buttons

Mamals

Neurite Retraction

WT

TLR3 or TLR8 overexpression
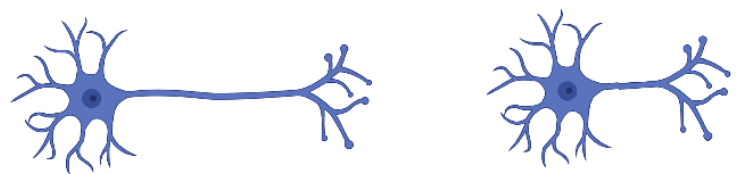

Figure 6. Role of TLR on cell fate, differentiation, and neural plasticity. Image adapted from Anthoney et al. (69). 


\subsubsection{The Role of TLRs in Neuroinflammation and Neurodegeneration}

Due to the inflammatory role of TLRs, neurons may suffer compromise in response to neuroinflammation. The increased expression of TLRs in the brain and spinal cord has been described in patients with Alzheimer's disease, Parkinson's disease, and amyotrophic lateral sclerosis (ALS), suggesting a pivotal role for TLR activation in CNS pathologies.

Although TLR3 represents one of the most highly expressed TLRs in the rodent and human CNSs, the role of TLR3 in neurodegeneration remains poorly described (57). Exposure to the TLR3 agonist polyinosinic:polycytidylic acid (poly I:C) increases COX2 activity and prostaglandin E2 synthesis in microglial cultures (84). Interestingly, the increased expression of TLR3 in Alzheimer's disease microglia has been linked to $\beta$ amyloid plaque deposition (85).

The increased levels of TLR8 in the blood in patients with cerebrovascular accidents have been correlated with increased inflammatory responses and a worse prognosis (86). TLR8 levels are also increased in the rodent brain after induced stroke, while the administration of a TLR8 agonist before stroke results in a more significant injury size (87). TLR8 levels in humans and mice associates with neural damage, resulting in fewer and shorter neurites and cell death $(86,87)$. 
Bsibsi et al. have demonstrated that human microglial cell cultures from Alzheimer's or Parkinson's disease patients express higher levels of TLR5 in comparison to healthy donors (88). Elevated expression of TLR5 has also been observed in different brain areas, including the substantia nigra, striatum, cerebral cortex, and dentate nucleus, in patients with ALS (89) and the brainstem of a Parkinson's disease rodent model (90).

Higher levels of TLR7 expression have also been noted in the cortex of an Alzheimer's animal model (91) and the spinal cord of an ALS animal model (92) compared with healthy tissue.

TLR9 is overexpressed in the substantia nigra and putamen of Parkinson's disease patients, in the striatum of a mouse model of Parkinson's disease (92), and the ALS mouse spinal cord (90). TLR9 activation with CpG-DNA in mouse microglial cultures induces the expression of $\mathrm{TNF} \alpha$ and nitric oxide (93), which induces neuronal toxicity in co-culture (94). Moreover, intracerebroventricular infusions of CpG-DNA caused impairment in spatial memory, microglia activation, and acute axonal damage using TLR9-deficient mice (95). The intrathecal injection of a synthetic $\mathrm{CpG}$ oligodeoxynucleotide (ODN), an agonist of TLR9, induced neuron loss, axonal injury in the cerebral cortex, and pronounced microglial activation in the mouse brain (96). 
Overall, TLR2 and TLR4 are the most studied TLRs regarding neurological-related diseases (97) as they recognize the largest number of DAMPs in conditions that generate sterile inflammation, which triggers the release of multiple endogenous ligands (98).

The activation of TLR2 in the microglia of a rat model of Alzheimer's disease enhanced $\beta$-amyloid plaque formation (99), while TLR2 inhibition decreased glial cell activity, reduced $\beta$ amyloid plaques deposition, and improved cognitive performance in transgenic mice (100). Mechanistically, TLR2-dependent $\mathrm{JNK} / \mathrm{NF \kappa B}$ signaling partially contributed to the inflammatory response (101), and TLR4-dependent JNK signaling can activate cleaved-caspase 3 signaling to induce neural apoptosis (102).

Interestingly, studies in Alzheimer's disease models have shown both beneficial and detrimental roles for TLR4. TLR4deficient mice exhibit a reduction in microglial activation but an increase in the level of $\beta$-amyloid plaque deposition and reduction in cognitive function (103). Chronic stimulation of TLR4 with LPS reduces cerebral hyperphosphorylation of Tau and recovers memory impairment through the microglia-dependent activation of autophagy (104). The LPS-mediated stimulation of TLR4 in mouse microglia culture prompted a rise in $\beta$-amyloid peptide production, which prompted a more robust inflammatory response (105). Of note, the coupling of CD14 to TLR2 and TLR4 in microglia is necessary for the induction of the immune 
responses associated with fibrillar $\beta$-amyloid peptide phagocytosis (106).

In the case of Parkinson's disease, the $\alpha$-synuclein protein released by neurons acts as an endogenous ligand for microglial TLR2, which prompts the production of toxic molecules, such as TNF $\alpha$, IL1 $\beta$, IL6, and nitric oxide, and increases the inflammatory response through $\mathrm{NF} \kappa \mathrm{B}$ activity and inflammatory monocytes and leukocytes, thereby leading to neurodegeneration $(107,108)$. Interestingly, a study has established the essential nature of TLR4 for the induction of microglial responses against $\alpha$-synuclein in vitro, such as $\alpha$-synuclein uptake and the release of pro-inflammatory cytokines and reactive oxygen species (ROS) (109). Impaired microglial phagocytosis, enhanced neuronal loss, and exacerbated motor dysfunction after TLR4 ablation has also been reported in a transgenic mouse model of multiple system atrophy with oligodendroglial $\alpha$-synuclein overexpression (110). Casula et al. also demonstrated that higher TLR2 expression in glial cells, mainly in microglia and macrophages, prompts more significant immunoreactivity when compared to healthy spinal cord tissues (111).

Interestingly, analysis of TLRs has also led to treatment approaches for neurodegenerative conditions. TLR4 antagonist treatment decreased microglial activation, exerted neuroprotective effects, and improved behavioral performance in an model of motor neuron degeneration (112). 
In animal models of stroke, studies have described an increase in TLR2 expression in damaged cortical and hippocampal neurons $(102,113)$. As previously described, TLR2 deficient mice showed limited brain damage and reduced levels of infarct volume, neurological deficits, inflammatory cell accumulation, and neural damage after induced stroke (51).

Meanwhile, TLR4 exhibits both beneficial and detrimental effects in stroke models. Neurons of mice after ischemia/reperfusion (I/R) injury suffer TLR4 upregulation, suggesting the involvement of TLR4 in stroke-induced brain damage $(48,113)$; however, mice systemically treated with low doses of LPS two days before I/R injury possessed smaller infarct sizes and lower levels of neuroinflammation, while TLR4 deficient mice had lower levels of stroke-induced brain damage and neurological deficits after I/R treatment (48). Overall, TLR4 stimulation before stroke may have a protective role, while TLR4 stimulation during stroke might be detrimental. 


\subsection{TLR in Spinal Cord Injury}

TLRs can initiate intracellular signaling by binding to DAMPS such as ROS, cytokines, and neuropeptides (114). "Sterile inflammation" occurs when DAMPS become released into the extracellular environment to induce an inflammatory response similar to that observed with microbial infections. Sterile inflammation in spinal cord injury (SCI) is marked by the recruitment of neutrophils and macrophages and the production of pro-inflammatory cytokines and chemokines, such as TNF $\alpha$ and IL1 $\beta$. Hyaluronan-binding hyalectans, which bind to TLR2 and TLR4 to stimulate inflammatory cytokines during astrogliosis (115), biglycan, which binds to TLR 2 and 4 in activated macrophages (116), chondroitin sulfate proteoglycans (CSPG), which binds to TLR2-TLR6 (117), and tenascin (118), which binds to TLR4 as a result of the disruption of the extracellular matrix (ECM) act as DAMPs during SCI.

Therefore, a wide range of TLR-dependent signaling cascades in glia and immune cells contribute to the pathophysiological sequelae of SCI. TLR-induced inflammatory signals have been implicated in both post-SCI degeneration and repair $(119,120)$. Of note, necrotic cells release DAMPs after SCI to rapidly induce the activation of $\mathrm{NF \kappa B}$ in microglia (121); therefore, an early signaling-initiated cascade mediated by select TLRs could trigger a feedforward cascade of inflammatorymediated neurodegeneration. 
TLRs are also involved in neuro-inflammatory associated damage after SCI. TLR2 and TLR4 deficient mice display a decreased expression of pro-inflammatory and neuropathic pain related-genes (122). Following SCI in rodent models, an increase in gene and protein expression of TLR1, 2, 4, 6, 7, and 9 has been observed within the injury foci $(122,123)$, which is maintained into chronic SCI (124). In addition, an increase in TLR signalingrelated molecules (MYD88 and IRAK4) has been observed after the subacute phase of SCI (122).

The use of specific TLR agonists and antagonists can discern each receptor's beneficial and/or detrimental effects and suggests their potential in SCI treatment. Stirling and co-workers previously demonstrated that Pam2CSK4, a synthetic diacylated lipopeptide that induces signaling through a TLR2/6 dimer, could increase microglial responses, reduce secondary degeneration of central myelinated fibers, and induce a mixed pro- and antiinflammatory alternative microglial activation profile, thereby suggesting Pam2CSK4 as a neuroprotective agent that could be administrated immediately after injury and suggesting TLR2 stimulation as a new therapeutic target in the treatment of SCI (125).

Interestingly, the use of the TLR3 agonist poly(I:C) has a described neuroprotective role after SCI in I/R models by decreasing TLR4-mediated signaling (126). Furthermore, TLR3 stimulation by exogenous factors leads to the production of 
Hipoxia Inducible Factor $1 \alpha$ and Vascular Endothelial Growth Factor (VEGF) that modulate macrophage-mediated inflammation (127).

Studies have also identified TLR9 ligands that modulate the inflammatory response following SCI (128). The TLR9antagonist CpG ODN 2088 specifically decreases the expression of pro-inflammatory cytokines and chemokines, reduces the number of infiltrating immune cells, increases white matter preservation, and limits the development of neuropathic pain and bladder dysfunction $(129,130)$. In contrast, the TLR9 agonist CpG ODN 1826 exacerbated inflammation and bladder dysfunction (129). The current hypothesis states that CpG ODN 2088 confers neuroprotection by attenuating the inflammatory reaction at the injury epicenter and directly protecting neurons from secondary damage. CpG ODN 2088 may interfere with the binding or action of TLR9-specific DAMPs and thus confer neuronal protection by preventing their deleterious effects.

Blocking downstream signaling of TLRs may also be of therapeutic interest. Inhibition of the MyD88-dependent pathway with the inhibitor peptide MIP reduces TNF $\alpha$ and IL-1 $\beta$ levels and inhibits p38-MAPK activation in the injured spinal cord (131). Blocking MyD88 signaling in this manner inhibits the NFKB pathway and decreases the production of pro-inflammatory cytokines in spinal tissue (131). Therefore, the inhibition of the MyD88-dependent pathway immediately after SCI may protect 
spinal cord tissue from inflammation, reduce apoptosis, and promote functional recovery (132).

TLR4 has been more extensively explored in SCI, with contrary reports suggesting roles in neuroprotection (133) but also in pro-inflammatory and neurotoxic reactions (112). TLR4 mRNA is upregulated in the injured spinal cord, and blocking TLR4 signaling reduces the inflammatory reaction to provide neuroprotection (132). Heat shock proteins released from damaged neurons activate microglia and TLR4 expression in microglia and macrophages to include the inflammatory response (134). Necrotic neurons activate microglia through the MyD88pathway, which enhances microglia activation-mediated neurotoxicity through the positive regulation of glutaminase activity (135). Results from several experiments suggest that hemorrhage in the spinal cord induces an immune reaction involving TLR4 signaling in 0microglia and macrophages (136).

SCI in TLR4 knock-out mice induced significantly greater levels of demyelination, astrogliosis, and macrophage activation than wild-type animals, even though knock-out mice expressed higher levels of pro-inflammatory cytokines such as IL1 $\beta$ (122). Recent studies suggested that TLR4 deficient mice developed more serious hind limb motor dysfunction, increased levels of neuronal death, and elevated levels of expression of MYD88, $\mathrm{NF} \kappa \mathrm{B}, \mathrm{TNF} \alpha$, IL1 $\beta$, Glial fibrillary acidic protein (GFAP), CD11, iNOS, and nitrotyrosine expression compared to wild type mice 
(137). In addition, the absence of TLR4 also led to a decrease in phosphorylated IRF3 and IFN $\beta$ release at one-week post-injury. These results suggest TLR4 as an important requirement for limiting the extent and duration of SCI. The apparent redundancy and breadth of TLR signaling may also explain why both neuroprotective and neurotoxic effects have been described for TLR4 (138).

OPCs can produce new oligodendrocytes that can remyelinate neural axons for at least three months after SCI (139). Although TLR4 expression has not been detected in myelinating oligodendrocytes, TLR4 is necessary for proper oligodendrocyte formation to promote functional recovery after SCI (139). Previous studies show that impaired TLR4 signaling in SCI exacerbates white matter pathology and impaired functional recovery (122). Intraspinal induction of TLR4 signaling induces OPC proliferation and oligodendrogenesis (140). Church et al. demonstrated that TLR4 signaling protects oligodendrocytes and OPCs immediately after SCI through their research in a TLR4deficient mouse model (141). Moreover, TLR4 signaling is essential for the normal timing and response of oligodendrocytes lineage cells.

Overall, the roles of TLR4 signaling after SCI include regulating the survival of oligodendrocytes, OPCs, and axons, promoting oligodendrocyte replacement, and facilitating the clearance of myelin debris. 


\section{SPINAL CORD INJURY: PATHOPHYSIOLOGY AND CELL THERAPY}

The loss of motor and sensory functions after SCI significantly impacts the patient's quality of life, with the specific medullar segment affected by the injury determining injury severity (Figure 7) (142). For instance, cervical lesions lead to tetraplegia, while thoracic lesions affect the lower extremities. Additional associated effects of SCI include neuropathic pain, spasticity, blood pressure deregulation, loss of bladder control, and sexual dysfunction (143).

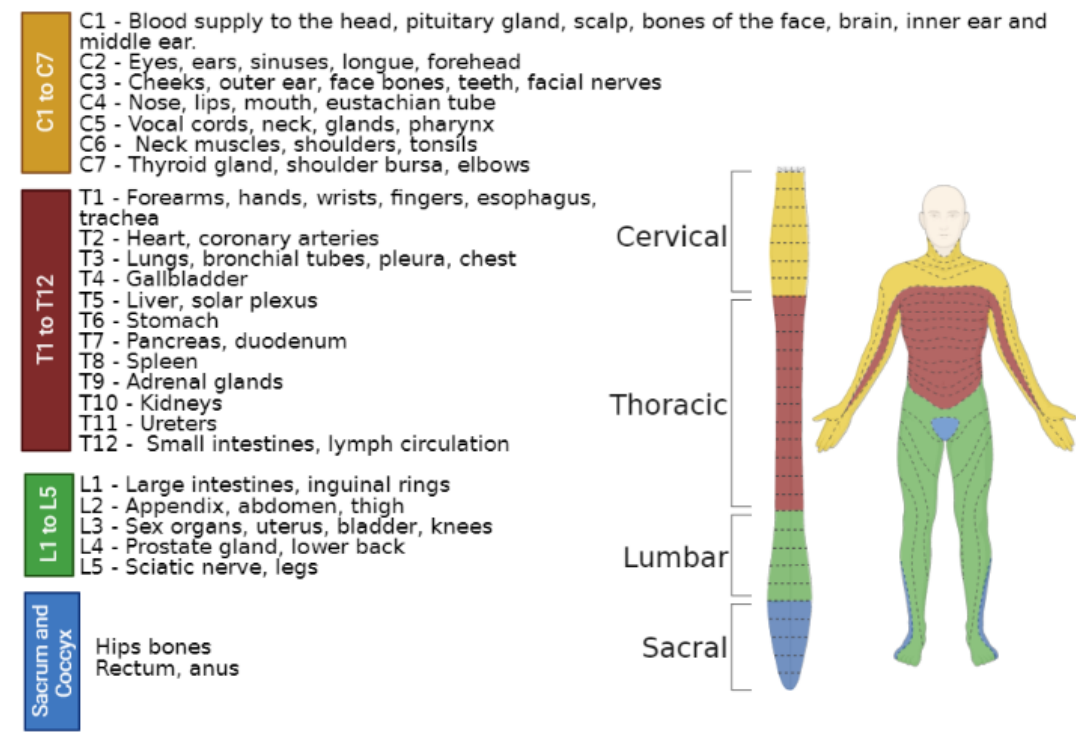

Figure 7. Schematic Representation of Spinal Cord Segments in human. Spinal cord segments (center) are classified as - C1-7, belonging to the cervical 
region (pink), T1-12, belonging to the thoracic region (purple), and L1-5, belonging to the lumbar region (light blue). An additional five segments are associated with the sacrum (dark blue) and one with the coccyx. The box on the left depicts the functions and organs associated with each segment. According to the affected segment, the image on the far right depicts the parts of the human body affected after a spinal cord injury.

According to the latest data from National Spinal Cord Injury Statistical Center, between 250,000 and 373,000 people in the United States suffer spinal cord injuries each year (144). The annual incidence of SCI is an estimated fifty-four cases per million people, with higher incidences in the 15-30 and above 60 age groups. SCI injuries also suffer from a much higher incidence in males (4:1) compared to females. Around 96\% of SCI injuries are not due to medical conditions, with traffic accidents (38.2\%), falls (32.3\%), violent attacks (14.3), and sports and leisure accidents $(7.8 \%)$ the major contributing factors.

Between 20 and $30 \%$ of injuries have a non-traumatic origin, with vastly different characteristics. These include viral and bacterial infections, inflammatory conditions (e.g., transverse myelitis and multiple sclerosis), cancer, degenerative disorders of the CNS (e.g., ALS, hereditary spastic paraparesis, and spinal muscular atrophy), rheumatic and degenerative conditions (e.g., stenosis, disc pathology, rheumatoid arthritis, osteoporosis, and vascular and iatrogenic injury) and congenital conditions such as spina bifida (145). 


\subsection{Pathophysiology of the SCI}

Following the immediate primary mechanical damage, the most common form of SCI, a harmful secondary cascade of cellular and molecular events that begins soon after, prompts the further loss of neurological activity (146).

The primary damage caused by a single or persistent compression, contusion, or laceration/transection can be accompanied by bone fracture and disk displacement, contributing to further spinal cord compression.

Secondary damage represents an umbrella term to describe the cellular and molecular events that continue to damage spinal cord tissue and block recovery (Figure 8). Secondary damage begins in the minutes and hours following primary damage, with the acute phase involving vascular damage, ionic imbalance, neurotransmitter accumulation (excitotoxicity), free radical formation, calcium influx, lipid peroxidation, inflammation, edema, and necrotic cell death. Injury progression to the sub-acute phase involves apoptosis, demyelination of surviving axons, retrograde degeneration of the distal end of an axon resulting from a nerve lesion (Wallerian degeneration), axonal dieback, matrix remodeling, and the evolution of a fibrotic scar around the injury site. The chronic phase of SCI involves the formation of a cystic cavity, continuing axonal dieback, and the maturation and consolidation of the fibrotic scar (147). 
In the acute phase of SCI, the loss of the bloodcerebrospinal fluid barrier facilitates cell infiltration and favors the expansion of edema, which increases the mechanical damage in the spinal tissue by additional compression. The ischemia produced by the lesion leads to the development of hypoxic regions and a decrease in glucose availability in the lesion site. Hypoxia and the disrupted blood flow cause an ionic imbalance and ROS generation, among other harmful consequences (148).

SCI-associated ischemia also leads to the accumulation of glutamate in the extracellular space, which causes neurotoxicity due to over-stimulation of NMDA, AMPA, and Kainate ionotropic receptors and the resulting influx of calcium ions into the cell leading to neuronal depolarization and subsequent death. The increase in calcium ions and glutamate damages the injured white matter, astrocytes, oligodendrocytes, and myelin by excitotoxicity (149). The activity of neuronal NMDA receptors in the grey matter increases the concentration of calcium ions in the cellular milieu, causing neuron and oligodendrocyte death (150). Moreover, the overload of calcium ions increases the activity of host protein kinases and phospholipases, leading to the formation of arachidonic acid, which activates COX metabolism to produce prostaglandins and ROS (151). Reactive oxygen and nitrogen species activate cytosolic polymerase that uptake and deplete $\mathrm{NAD}^{+}$, which impacts glycolysis, leading to ATP depletion and cell death (152). 
Neural and glial cell death occurs due to many factors, including accumulation of toxic blood components, higher extracellular concentrations of glutamate, ionic imbalance, intracellular ATP depletion, pro-inflammatory cytokine release from neutrophils and lymphocytes, and free radical formation (153). Oligodendrocytes begin to die four hours after injury, with a peak at seven days, which induces a rapid and progressive demyelination process $(154,155)$. The accumulation of myelin binding proteins, such as NOGO, MAG, and OMPG, inhibits axonal growth. In addition, other signals have been identified to favor and inhibit activity within neuronal receptors, including the shared ligand-binding receptors $\mathrm{NgR} 1$ and PirB, such as the p75NTR, TROY, and LINGO-1. These signals converge on the activation of the Rho-ROCK pathway, which interferes with axonal regrowth (156).

The accumulation of CSPGs within the fibrotic scar has also been classified as an axonal growth-inhibitory mechanism (157). Reactive astrocytes, mesenchymal cells, stromal cells, fibroblasts, and Schwann cells begin to proliferate and migrate to the lesion site and build a mesh-like structure of intermingled filamentous processes around the injury epicenter, forming a nonpermissive barrier (156). This phenomenon has a protective role, forming a barrier to contain the expansion of the injury into the adjacent segments. Indeed, the formation of the fibrotic scar may be essential for the reconstruction of the cerebrospinal fluid-blood 
barrier (159); however, the astrocytic barrier and the formed scar lead to exacerbated leukocyte infiltration, cell death, myelin damage, and reduced axonal regeneration capabilities (160).

The degenerative neuronal process continues and extends distal to the primary injury, with episodes of secondary neuronal death which can be extended until chronic stages, increasing and maintaining a detrimental neurological activity with minimal chances for regeneration (161). 
Uninjured

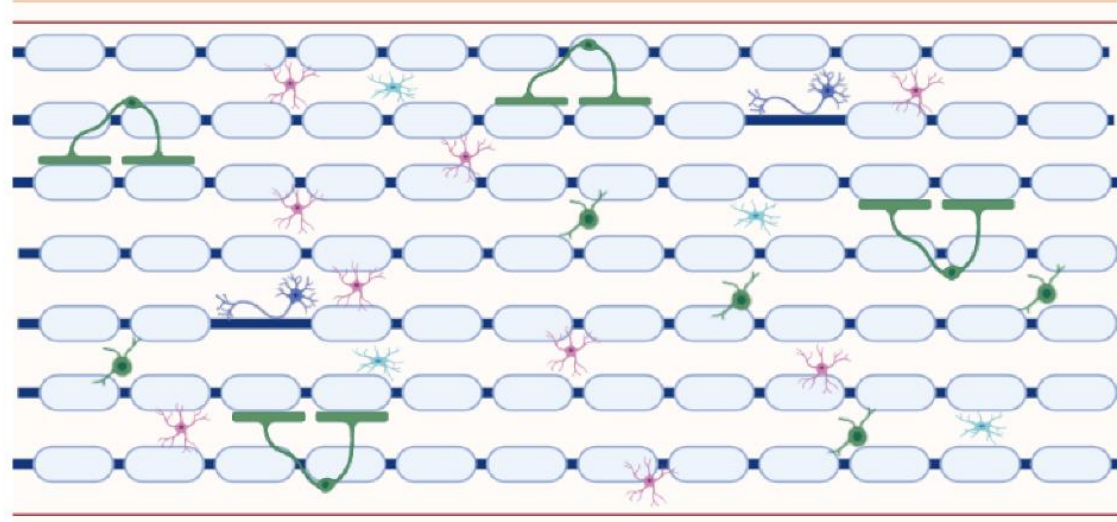

Subacute phase

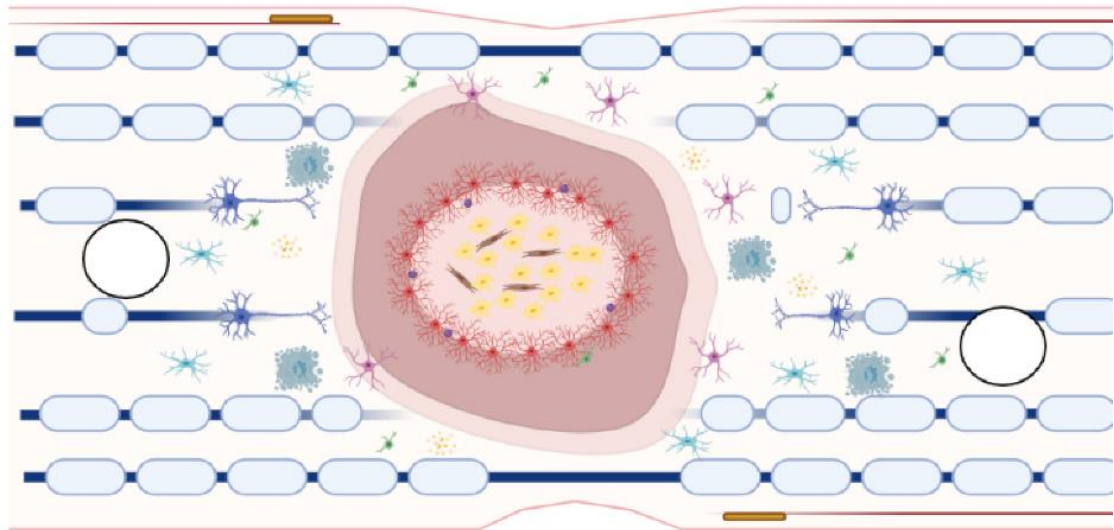

Chronic phase

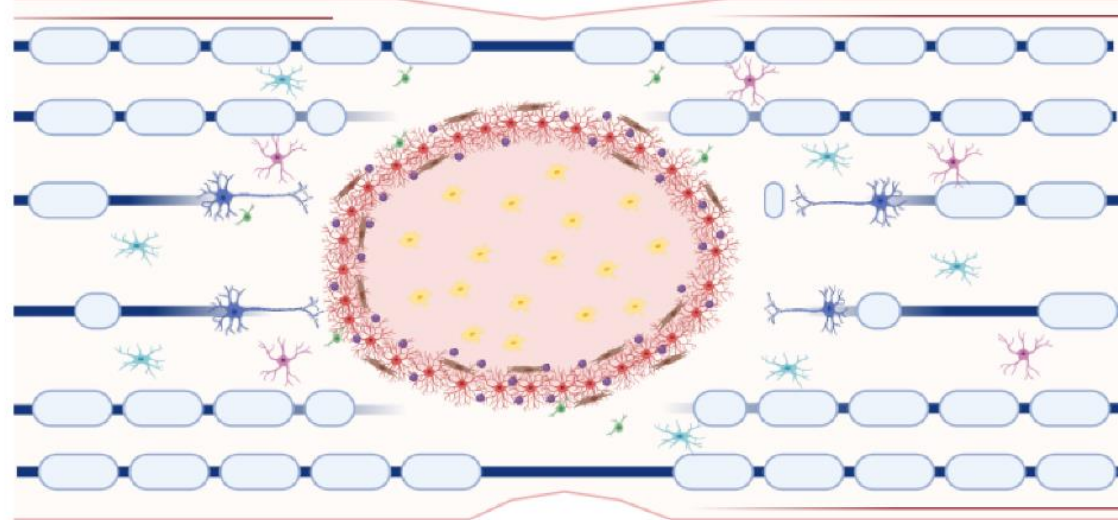




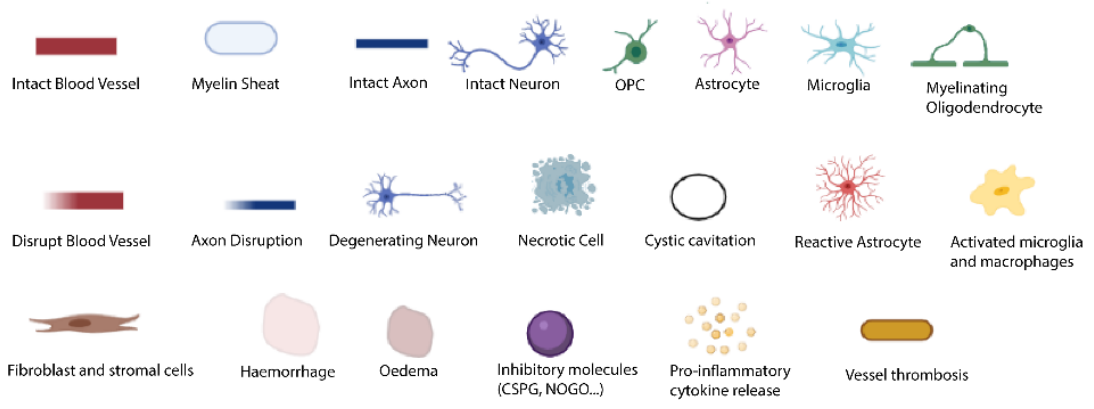

Figure 8. The pathophysiology of the spinal cord before and after injury. The uninjured spinal cord contains axons wrapped in myelin. OPCs, microglia, and astrocytes are found throughout white and gray matter, and neural soma are intact. At the subacute stage of SCI, there is considerable loss of neurons, axons, oligodendrocytes, and myelin. Axons die back from the lesion site, and myelin debris accumulates. Activated microglia, hematogenous macrophages, and other inflammatory cells are recruited to the lesion site; astrocytes become reactive by extending processes and proliferating and along with fibrotic cells forming a scar. OPCs and other cells also staining for the neural/glial antigen$2\left(\mathrm{NG}_{2}{ }^{+}\right.$cells) also proliferate and are recruited to the scar. At the chronic stage of SCI, the astrocytes and other cells further thicken the scar, a fluid-filled cavity is frequently formed at the lesion center. Activated microglia and macrophages persist within the lesion, though at reduced numbers compared to the subacute period. Some OPCs differentiate into new oligodendrocytes that produce myelin, and Schwann cells are often found myelinating axons near or in the lesion epicenter.

\subsection{Neural Progenitor Cell Transplantation in SCI}

Cell therapy is a promising strategy for SCI. Several mechanisms for recovery have been proposed, depending on the cell type; these include 1) replacement of oligodendrocytes or 
neurons, 2) re-myelination of spared axons, 3) restoration of neuronal circuitry and enhanced preservation of host neuronal and glial cells, 4) increased expression of neurotrophins and cytokines by transplanted or host cells, 5) promotion of angiogenesis, 6) bridging of cysts or cavities, 7) reduced inflammation or gliosis, 8) stimulation of endogenous precursor cells, and 9) the creation of a favorable environment for plasticity and axonal regeneration (162).

The Aguayo group undertook pioneering research in the 1970s by successfully transplanting peripheral nerve grafts to promote the regeneration of CNS axons (163). These findings supported studies from the Reier group in the 1980s, who used grafted fetal spinal cord to support the regrowth of host axons (164).

Current pre-clinical models have demonstrated that cell therapy can cover two significant challenges in the treatment of SCI: a) to reduce the side effects derived from the injury, thanks to neuroprotection, and b) to recover lost tissue through neuroregeneration.

In 2018, the US Food and Drug Administration approved the clinical use of NSI-566 (165), an immortalized NPC line derived from human early fetal spinal cord tissue for the treatment of SCI and ALS $(166,167)$, which had demonstrated success in the treatment of ischaemic motor stoke (NCT03296618). In the 
same year, several clinical studies evaluated human NSC transplantation for chronic patients with stable neurological deficits due to thoracic and cervical SCI, where NSCs were found to be safe and feasible $(168,169)$. More recently, the first licensed trial for the clinical evaluation of reprogrammed neural progenitor cells derived from induced pluripotent stem cells (iNPCs) in patients with chronic SCI in Japan (170). Treatment with iNPCs prompted locomotor improvement without tumor formation (171), which all derived from studies from the Okano group who previously demonstrated the functional benefits of iNPCs in severe to moderate traumatic SCI in rodent (172) and primate models (173). Figure 9 shows the potential benefits of NPC transplantation.

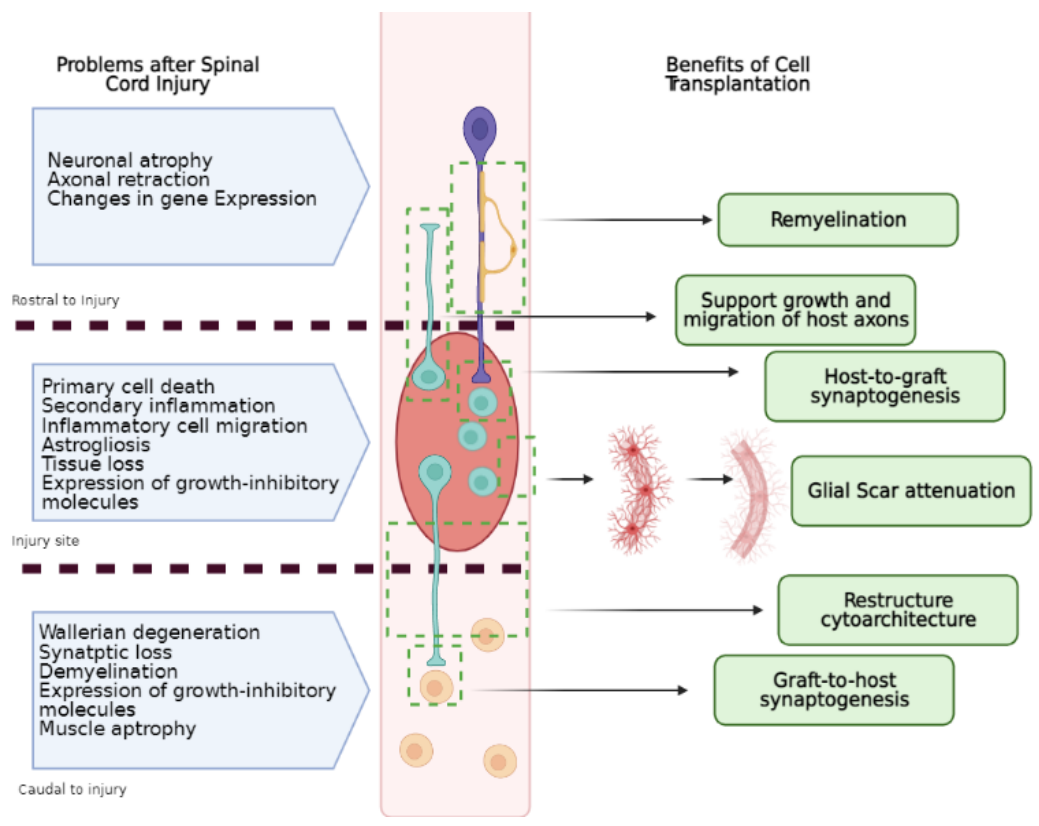


Figure 9. Pathophysiological events and potential therapeutic targets after SCI. The left side of the schematic illustrates the complex changes that occur after spinal cord injury, which differ temporally and spatially. The right side illustrates potential therapeutic targets for cell transplantation, including remyelination, support of host axon growth, glial scar attenuation, synaptogenesis and the restructuring of spinal cord cytoarchitecture. Image adapted from (174).

The employed cell therapy strategies included expanded NPCs in vitro, in a native stage $(175,176)$, induced to differentiate in a defined cell fate $(177,178)$ or genetically modified (179) for SCI treatment have demonstrated the more promising strategy. Additional variables that affect therapeutic outcomes include the mode of administration (intramedullary, intrathecal, or intravenous) and the transplantation location (rostral and/or caudal and/or intra-injury).

NPCs are multipotent cells that differentiate into neural lineages (180). In vitro, NPCs display a considerable capacity for self-renewal and expansion, making them a simple source to manipulate. NPC culture occurs in three-dimensional (3D) aggregates (neurospheres-like culture) formed in the presence of growth factors, such as epidermal growth factor (EGF) and fibroblast growth factors 2 (FGF2) for rodent NPCs (180), and with additional factors such as leukemia inhibitory factor (LIF) and ciliary neurotrophic factor (CNTF) for human NPCs (181). NPC in neurosphere-like form are primarily formed by progenitor cells, a small percentage of stem cells, and many differentiated 
cells (182). They have been found in both fetal (183) and adult (184) tissue. NPCs are present in the subventricular zone (SVZ) of the lateral ventricle walls (185), the subgranular zone (SGZ) of the hippocampus (186), the dentate gyrus (187), and ependymal cells from spinal cords (64).

NPCs can replace lost host cells, bridge lesions (188), recover myelin sheaths from reconstituting neuronal circuitry and lost connectivity (189), provide trophic support (190), and modulate neuroinflammation (191). NPC grafts induce reconnections in the corticospinal tract between host and graft cells (192), and project themselves over very long distances and establish synaptic connections with the host circuits after SCI $(175,193,194)$. Moreover, NPC grafts differentiate with ventral vs. dorsal patterning to recapitulate the regular anatomical neuronal organization lost after SCI. Transplanted NPCs migrate and differentiate largely into oligodendrocytes (194). In nonhuman primate models, NPCs grafts prompt axonal regeneration, synapse formation between the graft and host, functional improvement in the frontal extremities after several months (175). NPCs have demonstrated that enhanced angiogenesis through secretion of VEGF which promote neuroprotection mechanisms (195). The differentiation of NPCs into neurons has been proposed as a mechanism controlling the recovery of hindlimb locomotor function $(196,197)$. 
Although there are studies that show an improvement in functional recovery, the low survival rate and uncontrolled differentiation of the graft make it necessary to apply combination therapies. Fehlings's group have used the potency of HumanNPC in combination with other therapies such as chondroitinase ABC to improve the survival of NPCs (198). Moreover, Fehlings's laboratory use NPC in combination with glial derived neurotrophic factor (GDNF) to improve the differentiation of graft from cells to neurons in a murine injury model (199). On the other hand, Moreno's group has demonstrated the role of spinal cord-derived NPCs in axonal regeneration following injury (200). After that they use a combination therapy with drugs such as FM19G16 that increase the preservation of neurons and oligos after transplantation (201) and pre-treating cells with PGA-SS-F in water phase after transplantation to improve motor recovery and in chronic neural fibre preservation in spinal cord injury model (202). 


\section{HYPOTHESIS}

AND

OBJECTIVES 
The TLRs represent critical effectors in the host defense response against various pathogens, and while TLRs play wellunderstood roles in innate immunity, they may also function as critical effectors during development. Recent research has also described a role for the TLRs in cell fate determination, neural differentiation, and neurogenesis. While glial cells, neurons, and NPCs of the spinal cord express TLR2 and TLR4, their influence on self-renewal, cell differentiation, and whether these cells respond to SCI remains incompletely described.

NPC transplantation represents a relevant strategy for functional regeneration post-SCI; however, adequate survival, differentiation, engraftment, and integration into the endogenous neuronal circuitry will impact therapeutic outcomes. Although the spinal cord is considered an immune-privileged tissue, tolerance to ectopic cell transplantation after SCI in immunocompetent recipients is very low. Cell survival rates are generally no greater than $1-2 \%$ due to the massive immunerelated reactive cascades occurring at the injury site. Whether TLR2 and/or TLR4 contribute to the immune rejection of transplanted NPCs and the potential modulation for improvement of NPC transplantation approaches remains unknown. 
Hypothesis and Objectives

To answer these questions, we have proposed the following experimental and concise objectives:

* To study the role of TLR2 and TLR4 expression in mouse spinal cord NPCs

* To study how TLR2 and TLR4 may modulate neuronal function after NPC transplantation in a model of SCI

* To study the role of TLR4 in the CSPG-mediated immunomodulatory effect in SCI 
MATERIALS AND

METHODS 


\section{ANIMAL MODELS}

All animal experiments were undertaken in accordance with guidelines established by the European Communities Council Directive (2010/63/EU) and the Spanish regulatory guideline 1201/2005, also in accordance with the United Kingdom Animals (Surgical Procedures) Act 1986, approved by the Animal Welfare and Ethical Review Body (AWERB) of King's College London and conducted under Home Office Project License 70/8032. Experimental procedures were approved by the Institutional Animal Care and Use Committee (2018/VSC/PEA/0056) and animals were managed by trained staff. Water and food were provided ad-libitum throughout the experimental timeframes with general aspect, behaviour, and body weight evaluated daily to ensure animal welfare. They were maintained with water and solid diet ad libitum under controlled conditions of temperature $\left(23{ }^{\circ} \mathrm{C}\right)$, humidity (60\%), and light/ dark cycles $(12 \mathrm{~h} / 12 \mathrm{~h})$.

The experimental model used for Chapter 1 and 2 were C57BL/6 wild-type (WT) (Harlan Ibérica, Barcelona, Spain) and, TLR4 and TLR2 knockout (TLR4 ${ }^{-/}$, TLR2 ${ }^{-/}$) mice (C57BL/6 background, kindly provided by Dr. S. Akira (Osaka University, Suita, Japan) (203). 


\subsection{Chapter 1 animal models}

Neonatal (p5-7; females and males) of the three genotypes $\left(\mathrm{WT}, \mathrm{TLR}^{-/-}, \mathrm{TLR}^{-/}\right.$) were used. Mice were sacrificed by decapitation in accordance with the Animal Care and Use Committee. After verifying death, the skin, muscles, and adipose tissue covering the vertebrae were discarded and the vertebrae removed from the cervical to the lumbar spine, leaving the entire spinal cord exposed. The spinal cord was carefully removed by cutting the lateral dorsal ganglia that join to the vertebrae and then placed in DMEM + 2x penicillin/streptomycin $(\mathrm{P} / \mathrm{S})$ on ice for cell culture (see NPC culture in this section) or in $4 \%$ paraformaldehyde (PFA) for $4 \mathrm{~h}$ at $4^{\circ} \mathrm{C}$ for histological examinations. For histology, spinal cords were placed in paraffin, moved to histology cassettes, and processed with a Leica ASP 300 tissue processor (Leica Microsystems, Nussloch, Germany). $7 \mu \mathrm{m}$ thick transversal sections in the vertical plane were cut on the microtome and carried on gelatin-coated slides, collecting five series.

\subsection{Chapter 2 animal models}

Figure 10 provides a summary of the animal used for in vivo spinal cord injury and cell transplantation model using C57/BL6 mice. 
A) * $*$ Week 0 Week 1 Week 2 Week 3 Week 4 Week 5

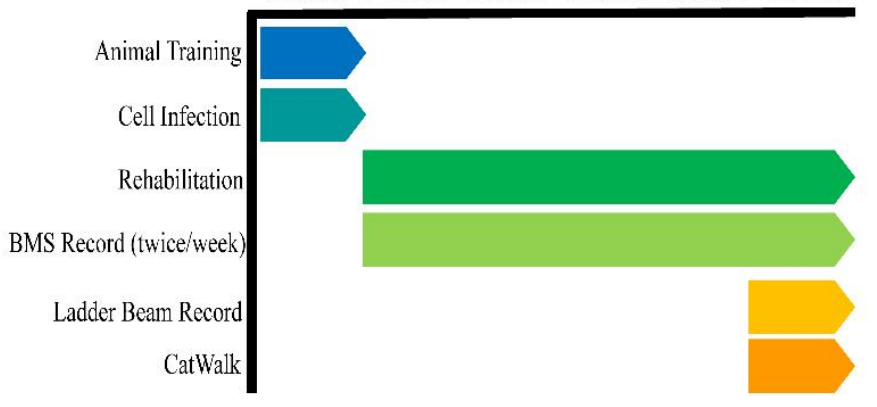

B)

* Surgery and Cell Transplantation

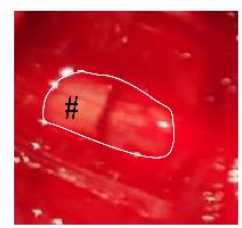

C)

Experiment 1: Animals + Growth media

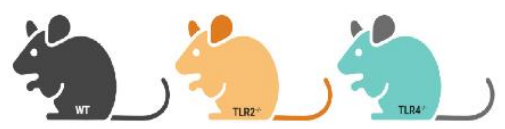

Experiment 3: Animals + WT-NPC Transplantation
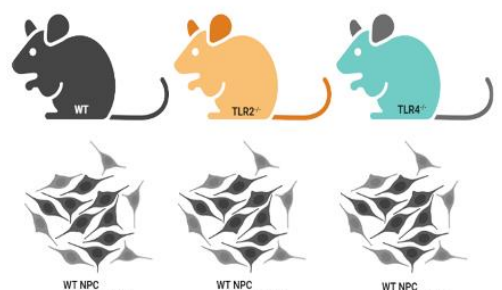

WT NPC
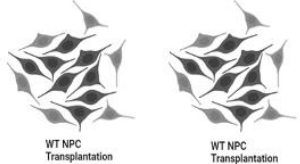

Experiment 2: WT Animals + NPC Transplantation
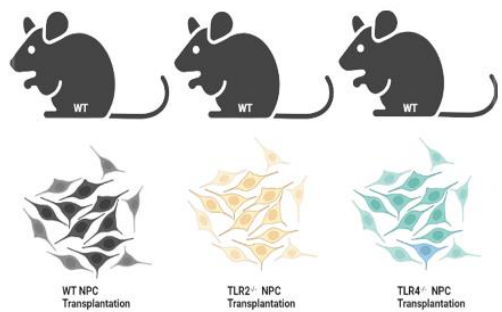

Figure 10. Summary of Animals used in Chapter 2. A) Schematic representation of the experimental design over six weeks. At week 0 , the animals were trained, and cells for transplantation were lentivirally infected 
with lentivirus containing EGFP transgene. From week 1 to 5, the specified behavioral tests were performed (BMS, Ladder beam, and CatWalk) accompanied by active and passive rehabilitation. B) On day 1(*), surgery and transplantation of the cells were performed. \# Shows site of cell transplantation. On day $35(*)$, after performing the final behavioral tests, spinal cords were obtained and divided into three pieces: $1 \mathrm{~cm}$ containing the lesion zone was stored under appropriate conditions for further histological processing, while the rostral and caudal segments were stored under appropriate conditions for analysis by molecular biology techniques. C) In vivo experiments were subdivided into three sub-experiments: 1) WT, TLR2/-, and TLR4 ${ }^{-/}$mice transplanted with growth media (Control), 2) WT mice transplanted with NPCs derived from WT, TLR $2^{-{ }^{-}}$, or TLR $4^{-{ }_{-}}$neonatal mice, and 3) WT, TLR2 ${ }^{-/-}$, and TLR $4^{-/-}$mice transplanted with WT-NPCs.

\subsubsection{Spinal cord compression model}

Spinal cord compression in animal models via the occlusion of the central canal is frequently used in SCI research (204) . Clips, balloons, and forceps are used to created graded and reproducible injuries. These models can be fine-tuned so that injuries of varying degrees can be created. Induced injury leads to the formation of fluid-filled cysts surrounded by spared tissue. The remaining tissue continuity and axon sparing also make this model suitable for functional locomotor evaluations (205). Overall, this model of SCI represents a consistent, reproducible, and straightforward means to study inflammation after SCI (206).

Sixty adult female mice aged 10-12 weeks from the three genotypes were anesthetized with $3 \%$ isoflurane and $100 \%$ 
oxygen and maintained with $1.5 \%$ isoflurane and $100 \%$ oxygen during surgery. 30 mins before surgery, morphine sulfate (5 $\mathrm{mg} / \mathrm{kg}$ body weight) was administered as an analgesic. Anesthetized animals were placed on a warm plate $\left(37^{\circ} \mathrm{C}\right)$ during the surgery. After the cervical and dorsal areas were shaved and cleaned, a longitudinal incision was performed to remove adipose tissue and muscles and expose the T7 to the T10 vertebra. T8-T9 laminectomy was conducted, visualizing the spinal cord with the dura mater intact. Bonn Micro forceps (11083-07; FST) (0.3 mm wide) were used to induce a complete compressive SCI, holding the forceps closed for five seconds at the T8 segment after dorsal laminectomy.

\subsubsection{Cell transplantation}

NPC transplantation was performed immediately after injury. NPCs were derived from neonatal (p5-7) WT, TLR2 ${ }^{-/-}$, and $\mathrm{TLR}^{-/-}$mice. Before transplantation, NPCs were transduced with the pll3 lentivirus (LV) (reported in section NPC Transfection with EGFP-LV) to express green fluorescent protein (GFP). NPCs grown as neurosphere-like cultures were collected and disaggregated using StemPro Accutase Cell Dissociation Reagent (Thermofisher) and quantified to adjust a concentration of 100,000 cells $/ \mu 1$.

$3 \mu \mathrm{l}$ containing 300,000 cells were intramedullary injected into each animal $0.5 \mathrm{~mm}$ rostral to the lesion at a rate of 1.5 
$\mu \mathrm{l} / \mathrm{min}$. The injection was performed using a $10 \mu \mathrm{l}$ Hamilton syringe (Hamilton Company, Bonaduz, Switzerland) to which a siliconized glass tip with a diameter of $80 \mu \mathrm{m}$ was attached. The Hamilton syringe was attached to a Pump 11 Nanomite infusion pump (Harvard Apparatus, Holliston, USA). This concentration was decided on the basis of previous studies which have shown that the number of transplanted cells does not influence their survival, but depends on the microenvironment caused by the injury (207). For this reason, the immunosuppressant cyclosporine A ( $20 \mathrm{mg} / \mathrm{kg}$ body weight) was administered daily during the experimental procedure to support allogeneic cell transplantation.

\subsubsection{Post-surgery Procedure}

After surgery and four hours after morphine administration, mice were treated with the analgesic buprenorphine $(0.1 \mathrm{mg} / \mathrm{kg}$ body weight, twice daily for four days) for analgesic purposes and with the antibiotic enrofloxacin (5 $\mathrm{mg} / \mathrm{kg}$ body weight, once daily for seven days) to prevent possible infections. Animals were maintained with an electric blanket for the first 24 hours to prevent temperature loss due to a lack of thermoregulatory capacity; furthermore, a solid drink bag and food pellets were placed inside the cages. The bladders of all experimentally injured mice were manually emptied twice daily until autonomous bladder function was restored within 2-3 weeks after injury. 
Daily rehabilitation was performed for $15 \mathrm{~min}$, comprising passive mobilization through a full range of movements to maintain joint flexibility and reflexes in the hindlimbs. After the first week, active rehabilitation began by using a treadmill three times per week.

\subsubsection{Functional locomotor test}

Several tests were employed to evaluate the voluntary functional locomotor capacity of all animals.

\section{Horizontal ladder - Ladder Beam}

In ladder rung walking tests, the horizontal ladder evaluates mouse motor function and coordination function (originally introduced by Metz and Whishaw (208). Mice walk a distance of one meter on bars one centimeter apart (209). Recordings of each run are recorded, and the positions of each paw were evaluated at each step according to the following scale: 
Table 2. Scoreboard based on paw movement. Score adapted from (209).

\begin{tabular}{|c|c|}
\hline Score & Movement \\
\hline - (0 points $)$ & Paw pad does not present movement \\
\hline Miss (0.5 points) & $\begin{array}{l}\text { Paw pad does not contact beam, limb is } \\
\text { suspended }\end{array}$ \\
\hline Slip (1 points) & $\begin{array}{l}\text { Paw pad contact beam but does not contact in } \\
\text { subsequent step }\end{array}$ \\
\hline Skip (2 points) & $\begin{array}{l}\text { Paw pad does not contact beam but recover } \\
\text { contact in subsequent step }\end{array}$ \\
\hline $\begin{array}{l}\text { Toe step }(3 \\
\text { points })\end{array}$ & $\begin{array}{l}\text { Paw pad contacts do not fully support the } \\
\text { paw pad between more than } 2 \text { subsequent } \\
\text { steps }\end{array}$ \\
\hline $\begin{array}{l}\text { Plantar step }(4 \\
\text { points) }\end{array}$ & $\begin{array}{l}\text { Paw pad contacts completely beam between } \\
\text { more than } 2 \text { subsequent steps }\end{array}$ \\
\hline
\end{tabular}

The total score (Table 2) of the individual steps is averaged with the total number of the individual steps on one run. The ladder beam test was performed in the fifth week after SCI. The results were expressed as the \% score normalized to the maximum possible score of each animal according to the total number of steps taken (total step $* 4$ points).

$$
\text { Ladder Score } \%=\frac{\text { Score }}{\text { Max.Score }}
$$

Score $=$ summatory of number of steps scoring with corresponding score point (e.g., 10 step scoring with $2+5$ steps scoring with $1+20$ steps scoring with $0: 10 * 2+5 * 1+20 * 2=25$ score). 
Max. Score $=$ number of steps $*$ perfect movement (plantar $=4$ ) (e.g., $4 * 35$ steps $=140)$. In the example Ladder Score: $25 / 140=17.86 \%$.

\section{Basso Mouse Scale (BMS)}

The BMS test (210), which evaluates locomotor function in mice after SCI, represents an open field test where the paw and ankle movement, trunk stability, and step coordination of mice are analyzed over a set time frame. Animals were individually videotaped for three minutes of continuous movement. Table 3 shows the established scale where the movement of the hind paws, coordination, and weight-bearing are evaluated, with a score between 0 and 9 . The BMS test was performed and recorded twice a week from day seven after surgery. The analysis of the animal videos was performed by two unbiased observers who blindly scored results. 
Table 3. Scores and operational definitions for BMS for locomotion.

Table adapted from (210).

\section{Score Movement}

No ankle movement

Slight ankle movement

Extensive ankle movement

Plantar placing of the paw with or without weight support -OROccasional, frequent or consistent dorsal stepping dorsal but not plantar stepping

Occasional plantar stepping

Frequent or consistent plantar stepping, no coordination -OR-

Frequent or consistent plantar stepping, some coordinated, paws rotated at initial contact and lift off $(\mathrm{R} / \mathrm{R})$

Frequent or consistent plantar stepping, some coordination, paws parallel at initial contact (P/R, P/P) -OR- Frequent or consistent plantar stepping, mostly coordinated, paws rotated at initial contact and lift off (R/R)

Frequent or consistent plantar stepping, mostly coordination, paws parallel at initial contact and rotated at lift off (P/R) -OR-

7 Frequent or consistent plantar stepping, mostly coordinated, paws parallel at initial contact and lift off $(\mathrm{P} / \mathrm{P})$, and severe trunk instability

Frequent or consistent plantar stepping, mostly coordination, paws parallel at initial contact and lift off (P/P) and mild trunk instability -OR- Frequent or consistent plantar stepping, mostly coordination, paws parallel at initial contact and lift off (P/P) and normal trunk instability and tail down or up \& down Frequent or consistent plantar stepping, mostly coordination, paws parallel at initial contact and lift off $(\mathrm{P} / \mathrm{P})$ and normal trunk instability and tail always up 


\section{CatWalk: Gait analysis for mouse model}

The CatWalk is used to quantify neurofunction through a complete gait analysis system for quantitative assessment of footfalls and locomotion in rats and mice (211). CatWalk is a registered trademark of Noldus Information Technology, Wageningen, Netherlands. The CatWalk gait analysis system is a platform locomotor test in which animals cross a $7 \mathrm{~cm}$ wide walkway with a glass floor (131 cm long) located in a darkened room (212). The glass floor is illuminated from the side, so the light is scattered when a paw touches the glass. Three runs per animal were recorded by a high-speed camera (100 frames/s) that captures the paw prints from below. All four paws were automatically labeled using the CatWalk software and were evaluated afterward by a blinded experimenter for gait analysis. CatWalk software analyses the data to investigate the animal's gait and generate a large number of finely graded dynamic and static gait parameters that can detect subtle and nuanced changes.

CatWalk analysis was performed in the fifth week after SCI. Paw contact was quantified by counting high-intensity pixels as the mean of at least three rounds per analysis. Only animals with BMS scores greater than or equal to four and that supported their weight were evaluated. 


\subsubsection{Tissue Harvest for further histological and molecular analysis}

Animals were intraperitoneally anesthetized with 100 $\mathrm{mg} / \mathrm{kg}$ pentobarbital and $0.05 \mathrm{mg} / \mathrm{kg}$ fentanyl following established sacrifice protocols for the perfusion of experimental animals. After ensuring the absence of reflexes, the rib cage was opened, exposing the heart, and animals were perfused with 50 $\mathrm{ml}$ of saline with a peristaltic pump at a continuous flow rate of $10 \mathrm{ml} / \mathrm{min}$ to clear the tissues of blood. Once the animals had been completely perfused with saline to remove the blood from the tissue, spinal cords were removed and subdivided into three groups - Rostral - Injury - Caudal. $1 \mathrm{~cm}$ of tissue containing the injury site was postfixed for 4 hours in PFA $4 \%$ at $4{ }^{\circ} \mathrm{C}$ and then preserved in PBS with $0.05 \%$ sodium azide. Rostral and caudal tissues were kept at $-80^{\circ} \mathrm{C}$ for subsequent RNA and protein extraction. Injured tissue was placed in paraffin, moved to histology cassettes, and processed with a Leica ASP 300 tissue processor (Leica Microsystems, Nussloch, Germany). Spinal cords-embebed in paraffin were cut on the microtome at $7 \mu \mathrm{m}$ thick longitudinal sections in the horizontal plane on gelatincoated slides. Slice were collected in 5 series with 5 sections per slice in order to study the entire depth of the spinal cord. 


\subsection{Chapter 3 animal models}

Bone marrow-derived macrophages were extracted from the tibias and femurs of adult female Lister Hooded rats (200220g; Charles River) and adult female C57/BL6 WT and TLR4 ${ }^{-/-}$ mice (23-25 g). Both rats and mice were sacrificed by lethal exposure to $\mathrm{CO}_{2}$ and subsequent decapitation.

Tibia and femurs were extracted carefully following the protocol described by Weischenfeldt and Porse (213) to ensure that the femur head is not damaged. The animal bones were stored in DMEM+P/S after washing twice with $70 \%$ ethanol in order to continue the culture of bone marrow-derived macrophages in sterile conditions.

\section{CELL CULTURES}

\subsection{Bone Marrow-derived macrophages (BMDMs)}

BMDMs were obtained from bone marrow cells flushed from the tibia and femurs of rats and mice, as described above. After removing the ends of the bones, the bone marrow was flushed out with ice-cold sterile DMEM media (Gibco TM) using a $23 \mathrm{G}$ or $25 \mathrm{G}$ needle for rats or mice, respectively. The bone marrow was then placed into a Falcon tube containing cold PBS and centrifuged for $7 \mathrm{~min}$ at $600 \mathrm{~g}$ at $4^{\circ} \mathrm{C}$. Red blood cells were then lysed with ACK (Ammonium-Chloride-Potassium) lysing 
Buffer for 30 seconds. The reaction was stopped by adding 20 volumes of $\mathrm{PBS}$ and centrifuged for $7 \mathrm{~min}$ at $600 \mathrm{~g}$ at $4^{\circ} \mathrm{C}$. After removing the supernatant, the remaining cells were resuspending in BMDM Media (DMEM + Glutamax $^{\mathrm{TM}}$ (Gibco TM)) supplemented with $10 \%$ fetal bovine serum (FBS) (Gibco TM), 50 units $/ \mathrm{ml} \mathrm{P} / \mathrm{S}$ and $25 \mathrm{ng} / \mathrm{ml}(500 \mathrm{U} / \mathrm{ml})$ macrophage colonystimulating factor (M-CSF, Peprotech)) and filtered through a 40$\mu \mathrm{m}$ cell strainer (Falcon).

Immature monocytes were cultured at a concentration of 200,000-250,000 cells/ $\mathrm{cm}^{2}$ in BMDM media at $37^{\circ} \mathrm{C}$ in a watersaturated atmosphere with $5 \% \mathrm{CO}_{2}$. M-CSF-containing media was replaced every three days until harvesting on day seven, at which time, monocytes will have differentiated into macrophages that can be isolated for different experiments. Cells were incubated with enzyme-free cell dissociation buffer (Millipore) for $15 \mathrm{~min}$ at $37^{\circ} \mathrm{C}$. Remaining adherent cells were scraped off the tissue culture plastic and, after centrifugation, cells were resuspended in BMDM Media without M-CSF and were seeded on poly-D-Lysine coated plates at a density of $1-1.2 \times 10^{5}$ cells $/ \mathrm{cm}^{2}$.

\subsubsection{BMDM polarization}

Macrophages were polarized with BMDM Media containing recombinant IL-4 (20ng/ml, Peprotech) for antiinflammatory polarization (M2) or containing LPS $(100 \mathrm{ng} / \mathrm{mL}$, 
Enzo Life Sciences) and IFN $\gamma$ (20ng/ml, Peprotech) for proinflammatory polarization (M1). Cells were cultured for $24 \mathrm{~h}$, and the polarization of rat and mouse BMDMs was evaluated by qPCR.

\subsection{Neonatal microglial cell and Astrocytes from mixed cultures.}

Primary microglia and astrocytes were obtained from mixed glia isolated from the forebrain of two-day-old Lister Hooded rat pups. Brains were isolated in Dulbecco's PBS (DPBS, Gibco TM) on ice, and the olfactory bulbs, cerebellum, midbrain, and meninges were removed. Forebrains were minced using a scalpel blade, and the tissue pieces were transferred into $15-\mathrm{ml}$ Falcon tubes using sterile plastic transfer pipettes. Samples were centrifuged at $300 \mathrm{~g}$ for $5 \mathrm{~min}$, DPBS discarded, and $1 \mathrm{ml}$ of 0.25\% Trypsin EDTA (Gibco $\left.{ }^{\mathrm{TM}}\right)$ with DNase I $(200 \mu \mathrm{g} / \mathrm{ml}$; Roche Diagnostics) per pup added to the tissue pellet and gently mixed. The tube was incubated in a $37^{\circ} \mathrm{C}$ water bath for $20 \mathrm{~min}$, and tissue was triturated gently using a $200-\mu 1$ micropipette. Warm DMEM/F12 complete medium (DMEM/F12 (Gibco ${ }^{\mathrm{TM}}$ ) supplemented with $10 \% \mathrm{FBS}$ and 50 units $/ \mathrm{ml}$ of $\mathrm{P} / \mathrm{S}$ ) was added to the pellet to dilute and inhibit trypsin. Subsequently, the cell suspension was centrifuged $\left(400 \mathrm{~g}, 5 \mathrm{~min} 4^{\circ} \mathrm{C}\right)$, resuspended in DMEM/F12 complete medium, filtered through a 70- $\mu$ m cell strainer, and seeded at 300,000 cells $/ \mathrm{cm}^{2}$ in a $75 \mathrm{~cm}^{2}$ T-flask (Corning) coated with $0.1 \mathrm{mg} / \mathrm{ml}$ poly-D-lysine. Cells were 
incubated at $37^{\circ} \mathrm{C}$ in a water-saturated atmosphere with $5 \% \mathrm{CO}_{2}$, and half media change was conducted on days 3, 7, and 10 .

After reaching confluence (10-12 days), flasks were shaken for 5 hours at $300 \mathrm{rpm}$ at $37^{\circ} \mathrm{C}$ to recover microglial cells. Microglia were plated onto $0.1 \mathrm{mg} / \mathrm{ml}$ poly-D-lysine-coated wells at a density of 100,000 cells $/ \mathrm{cm}^{2}$ for all subsequent experiments. Microglia were incubated for 24 hours with IL-4 (20ng/ml)supplemented media for polarization toward an M2 fate.

Astrocytes were obtained by the trypsinization (Trypsin+EDTA $0.05 \%$ (Gibco), $5 \mathrm{~min}$ at $37^{\circ} \mathrm{C}$ ) of the remaining cells, which were subsequently seeded at a density of 100,000 cells $/ \mathrm{cm}^{2}$ with DMEM/F12 complete medium.

\subsection{Adult microglial cell culture.}

Adult microglia were isolated using a modified version of an established protocol (214). Whole brains and spinal cord were isolated from Lister Hooded rats after whole-body intracardial perfusion with ice-cold DPBS containing $2 \mathrm{mM}$ EDTA. Tissue was homogenized using a $15-\mathrm{ml}$ size Dounce homogenizer in 5 $\mathrm{ml}$ ice-cold DPBS with ten strokes. Homogenized tissues were filtered through a $70-\mu \mathrm{m}$ cell strainer to remove any debris and centrifuged at $300 \mathrm{~g}$ for $7 \mathrm{~min}$ at $4{ }^{\circ} \mathrm{C}$. For myelin removal, pellets were resuspended in $7 \mathrm{ml}$ of $30 \%$ Percoll® (Sigma, P1644). After centrifugation at $800 \mathrm{~g}$ for $30 \mathrm{~min}$ at room temperature, the top layer (enriched with myelin) was removed. According to the 
manufacturer's protocol, microglia were selected from the cellenriched pellet using CD11b-conjugated magnetic microbeads (Miltenyi Biotec GmbH). Magnetic-activated cell sorted CD11b+ cells were flushed from LS columns designed for positive selection of cells (Miltenyi Biotech) and collected in DMEM/F12 complete medium. Microglia-enriched cells were seeded at 100,000 cells $/ \mathrm{cm}^{2}$ concentration in 24 well-plates precoated with poly-D-lysine $(0.1 \mathrm{mg} / \mathrm{ml})$. Microglia were then incubated for 24 hours with IL-4 (20ng/ml) to polarize them toward an M2 fate.

\subsection{Neural Progenitor Cell Culture}

NPCs were harvested from neonatal male and female (P57) $\mathrm{C} 57 \mathrm{BL} / 6 \mathrm{WT}, \mathrm{TLR} 2^{-/-}$, and TLR $4^{-/-}$mice. Mice were sacrificed by decapitation and spinal cords were dissected. Once the overlying meninges and blood vessels were removed, the dissected tissue was placed in fresh washing media (DMEM/F12 supplemented with 100 units/ml penicillin, $100 \mu \mathrm{g} / \mathrm{ml}$ streptomycin, $5 \mathrm{mM}$ HEPES buffer, 0.125\% NaHCO3, 0.09\% glucose) and cut into $1 \mathrm{~mm}^{3}$ pieces. Under sterile conditions, tissue was allowed to homogenize by disaggregating to single cells with $200 \mu$ pipette tip by two washes in washing medium followed by centrifugation at $300 \mathrm{~g}$ for $5 \mathrm{~min}$. Cells were seeded in adherent conditions in the presence of growth media (NeuroCult ${ }^{\mathrm{TM}}$ Proliferation Medium supplemented with NeuroCult ${ }^{\mathrm{TM}}$ Proliferation Supplement $\quad$ (STEMCELL Technologies, USA) including $20 \mathrm{ng} / \mathrm{ml}$ EGF (Invitrogen), 10 
ng/ml basic FGF (Invitrogen), 1X P/S, and $2 \mu \mathrm{g} / \mathrm{ml}$ heparin (Sigma)) for 4-5 days. The resultant neurospheres were transferred to ultralow-attachment plates and maintained at $37^{\circ} \mathrm{C}$ in an incubator with $100 \%$ humidity and $5 \% \mathrm{O}_{2}$. Debris and dead cells were removed by collecting cells and centrifuging every two days.

\subsubsection{Neurosphere Disaggregation}

To disaggregate neurosphere into individual cells, StemPro Accutase Cell Dissociation Reagent (Thermofisher) was used for $5 \mathrm{~min}$ at $37^{\circ} \mathrm{C}$ and then inactivated by 20 volumes of DMEM/F12.

\subsubsection{Freezing and Thawing}

Freezing: Single-cell solutions of NPCs were frozen in DMEM/F12 + 20\% FBS + 10\% DMSO at $1-2 \times 10^{6}$ cells per cryovial.

Thawing: Cryovials were partially thawed in a water bath at $37^{\circ} \mathrm{C}$ and then placed in a $15 \mathrm{ml}$ tube with four volumes of $\mathrm{DMEM} / \mathrm{F} 12$. After centrifugation for $5 \mathrm{~min}$ at $300 \mathrm{~g}$, the supernatant is removed, and the cells are resuspended in culture medium. 


\subsubsection{NPC Culture in adherent conditions}

NPCs were cultured and differentiated in adherent culture conditions using the Matrigel ${ }^{\mathrm{TM}}$ (Corning) substrate. Matrigel is a natural extracellular matrix-based hydrogel widely used for two-and three-dimensional (2D and 3D) in vitro cell cultures. Matrigel was diluted at 1:20 in DMEM/F12 and incubated for 1 hour at room temperature in the well of plate or coverslips. Two washes with DMEM/F12 are needed to remove residues before starting cell attachment. Individual cells at $40.000 \mathrm{cell} / \mathrm{cm}^{2}$ were grown on Matrigel substrate in growth media for $24 \mathrm{hrs}$ before experimentation. Primary neurospheres were placed into a Matrigel substrate in a small volume of growth medium for 20 minutes before fixation.

\subsubsection{Spontaneous Differentiation of NPC}

Individual cells were seeded at 40,000 cells $/ \mathrm{cm}^{2}$ on Matrigel $^{\mathrm{TM}}$ for seven days. Cells were supplemented with growth medium lacking EGF for two days, and were then supplemented for the remaining five days with differentiation medium (DMEM/F12 supplemented with 100 units/mL penicillin, 100 $\mu \mathrm{g} / \mathrm{mL}$ streptomycin, L-glutamine $2 \mathrm{mM}, 5 \mathrm{mM}$ HEPES buffer, $0.125 \% \mathrm{NaHCO} 3,0.6 \%$ glucose, $0.025 \mathrm{mg} / \mathrm{mL}$ insulin, $80 \mu \mathrm{g} / \mathrm{mL}$ apotransferrin, $16 \mathrm{nM}$ progesterone, $60 \mu \mathrm{M}$ putrescine, $24 \mathrm{nM}$ sodium selenite, $2 \%$ heat-inactivated FBS). After 7 days NPCs 
have been spontaneously differentiated into their three lineages: neuron, astrocyte and oligodendrocyte (182).

\subsubsection{NPC Population Doubling Analysis}

In non-adherent conditions, 500,000 single NPCs were seeded and allowed to grow as neurospheres. After three days, cells were disaggregated and counted. This process was repeated for 15-16 passages until they reached the plateau growth stage The mathematical formula below (215) was used to calculate the cell growth. $\mathrm{N}$ is the number of cells counted every three days, $\mathrm{M}$ is the number of cells seeded (500.000 cells), and time was always three days.

$$
\mathrm{PDL}=\frac{\text { time } * \log (2)}{\log (\mathrm{N})-\log (\mathrm{M})}
$$

\subsubsection{NPC Proliferation Assay by BrdU Incorporation and Ki67 Immune detection}

NPCs were dissociated and plated on Matrigel ${ }^{\mathrm{TM}}$ coated coverslips at $4 \times 10^{4}$ cells $/ \mathrm{cm}^{2}$ in growth medium. 24 hours later, the media was replaced with fresh growth medium containing 10 $\mu \mathrm{M}$ bromodeoxyuridine (BrdU; Roche) and incubated for 90 minutes. Cells were then fixed with $4 \%$ PFA for 10 minutes, washed, and incubated with $2 \mathrm{~N} \mathrm{HCl}$ for $20 \mathrm{~min}$ at room temperature. The $\mathrm{HCl}$ was then neutralized with a $0.1 \mathrm{M}$ sodium borate $(\mathrm{pH}$ 8.5) for 5 minutes before the double immunofluorescence assay. 


\subsubsection{NPC Transfection with EGFP-LV}

The production of lentiviruses containing a GFP plasmid was varied out following previously established protocols (216) and under the conditions established by the CIPF (Valencia, Spain). The lentivirus was produced in HEK293 cells by transducing with a mixture of the pLL3.7 plasmid, a lentiviral vector that expresses shRNA under the mouse U6 promoter and the CMV-EGFP reporter cassette, the packing Vector pCMVdR8.7 coding for the gag, pol, and rev packing proteins, and the envelope vector pMD2.VSVG. All plasmid vectors were kindly provided by Dr. Luders (IRB Barcelona, Spain).

The viral titer was obtained by serial dilution of virus $\left(10^{-}\right.$ 2 to $10^{-7}$ ) in HEK293 cells. Infected cells were left to express the virus for 72 hours, after which time they were analyzed through flow cytometry for the \% of GFP-positive cells. Titer was calculated using the following formula: Titer $=\left(\mathrm{P}^{*} \mathrm{~N}\right) /\left(\mathrm{D}^{*} \mathrm{~V}\right)$, where $\mathrm{P}=\%$ GFP-positive cells according to FACS, $\mathrm{N}=$ the number of cells at the time of transduction, $\mathrm{D}=$ dilution factor, and $\mathrm{V}=$ total volume of viral inoculum $(0.5 \mathrm{ml})$.

A single-cell suspension of NPCs was infected in growth media at a multiplicity of infection (MOI) (217) of 10 for 1 hour at $37^{\circ} \mathrm{C}$. After 1 hour, the cell medium was changed, and cells were left for 72 hours to express the protein. 


\subsection{Cell Stimulation}

BMDM from mouse and rats were incubate for 4 or 16 hours with CSPG (5ug/ml, Merk-Millipore) in growth media lacking M-CSF. 40,000 cells $/ \mathrm{cm}^{2}$ of NPCs grown as a monolayer in growth medium lacking FGF and EGF were stimulated with LPS (50 ng/ml, Sigma-Aldrich) for 30 or $60 \mathrm{~min}$.

\section{IMMUNOSTAINING}

\subsection{Sample preparation}

Tissue samples were deparaffinized and rehydrated using AUTOSTAINER XL TS5015 (Leica Microsystems) following the following steps: $10 \mathrm{~min}$ at $60^{\circ} \mathrm{C} ; 10 \mathrm{~min}$ Xylene; $10 \mathrm{~min}$ Xylene; 5 min Ethanol 100\%; 5 min Ethanol 96\%; 5 min Ethanol 96\%; and 5 min Ethanol 70\%. Samples then underwent an antigenic retrieval step using Tris-EDTA buffer $(10 \mathrm{mM}$ Tris Base, 1mM EDTA Solution, 0.05\% Tween 20 in PB, pH 9.0) for 25 minutes at $97^{\circ} \mathrm{C}$. Samples were cooled to $65^{\circ} \mathrm{C}$ and then washed with $0.1 \mathrm{M}$ PBS (pH 7.4) to remove the retrieval buffer.

Cell cultures were fixed for 10 minutes in $4 \%$ PFA in PBS at room temperature and washed with $0.1 \mathrm{M}$ PBS three times.

\subsection{Immunofluorescence}

Cells and tissue sliced were incubated in blocking solution for 1 hour at room temperature - 5\% Normal Goat Serum $+0.01 \%$ 
Triton X-100 in PBS for cells and 10\% FBS + 5\% Horse Serum $+0.05 \%$ Triton X-100 in PBS for tissue samples. Primary antibodies (Table 4) were prepared in their respective blocking solutions, and samples were incubated overnight at $4^{\circ} \mathrm{C}$ in humid conditions. Subsequently, three washes were performed for 15 min with PBS, and secondary antibodies (Alexa Fluor conjugated, Invitrogen) were incubated at 1:400 for $1 \mathrm{~h}$ at room temperature in the dark. Alexa Fluor-488 from goat was used against mouse, rabbit, and chicken antibodies, Alexa Fluor-555 from goat against mouse and rabbit antibodies, and Alexa Fluor647 from goat against chicken antibodies. Nuclei were visualized by incubating samples with 4',6-Diamidine-2'-phenylindole dihydrochloride (DAPI; 1:1000, Sigma) for $5 \mathrm{~min}$ at room temperature in the dark. After additional washes, tissue and cells were carried with Fluoromount Mounting Medium (ThermoFisher) for cells and Mowiol (polyvinyl alcohol-based solutions; SIGMA) for tissue slice and store at $4^{\circ} \mathrm{C}$.

Table 4. Primary antibodies for immunofluorescence assays.

\begin{tabular}{c|ccc}
\multicolumn{1}{c}{$\begin{array}{c}\text { PRIMARY } \\
\text { ANTIBODY }\end{array}$} & HOST & DILUTION & $\begin{array}{c}\text { PURCHASED } \\
\text { FROM }\end{array}$ \\
\hline \multirow{2}{*}{ B3-TUBULIN } & Mouse & $1: 400($ Cells $)$ & Neuromics \\
& & (Tissue) & ExBio \\
BRDU & Mouse & $1: 1000$ & Sigma
\end{tabular}




\begin{tabular}{|c|c|c|c|}
\hline FOXJ1 & Mouse & $1: 200$ & Invitrogen \\
\hline \multirow{2}{*}{ GFAP } & Rabbit & $1: 400$ & Dako \\
\hline & Chicken & $1: 1000$ & ThermoFisher \\
\hline GFP & Chicken & $1: 1000$ & Abcam \\
\hline KI67 & Rabbit & $1: 600$ & Abcam \\
\hline NEUN & Chicken & $1: 600$ & Millipore \\
\hline OLIG2 & Rabbit & $1: 400$ & Milipore \\
\hline PH2AX & Rabbit & $1: 800$ & Cell Signalling \\
\hline SOX2 & Rabbit & $1: 300$ & Abcam \\
\hline TLR2 & Mouse & $1: 50$ & $\begin{array}{c}\text { Santacruz } \\
\text { Biotechnology }\end{array}$ \\
\hline \multirow{2}{*}{ TLR4 } & Mouse & $1: 100$ & Proteintech \\
\hline & Rabbit & $1: 50$ & Biotechnology \\
\hline
\end{tabular}

\subsection{Image Analysis}

The quantification of positive cells for each antibody used was done by counting double positive cells with DAPI and subtracting the background with the relevant negative controls. The quantification of apoptosis using the levels of pyknotic nuclei stained with DAPI used the identification of labelled nuclei exhibiting a size below the average nucleus size and displaying 
hyper-condensation of chromatin (218) . Cell quantification analysis used at least fifteen random fields per group in triplicate in three individual cell cultures.

Area of the fibrotic scar was measured with GFAP signal in order to assess the extension of the glial or astrocyte scar. Fibrotic area was measured via the lack of GFAP expression counterstained by incubation with DAPI in $1.5 \mathrm{~mm}$ of length since core lesion to rostral and caudal, normalized to the total area of $3 \mathrm{~mm}$ of length measured.

$\beta$ III-Tubulin+ area was measured in order to assess conservation of axonal ascending and descending tracts and axonal regrowth into the lesion site. B3Tubulin signal was measured by Fiji software normalized to the total area between $1.5 \mathrm{~mm}$ of length in three sections. Sections were divided into Rostral, Injury and Caudal part. Injury area included core lesion in the middle and Rostral and Caudal section were set out below the injury section.

All quantified specific signals for each marker were normalized by the total analyzed area at equivalent tissue lengths, including the epicenter of the injury, in all groups using ImageJ software. Cell quantification analysis used at least fifteen random fields per group in triplicate in three individual cell cultures. For tissue analysis, all data were normalized to the total evaluated area using Image $\mathbf{J}$ software. 


\section{RNA ISOLATION, CONVERSION TO CDNA AND QUANTITATIVE}

PCR

Total RNA was extracted from cells and tissue using TRIzol® reagent (Thermo Fisher Scientific) following the product specifications. Cells were homogenized by pipetting and incubated for $5 \mathrm{~min}$ at room temperature in TRIzol. Tissue was homogenized using an ultraturrax homogenizer and incubated for $5 \mathrm{~min}$ at room temperature. An aqueous phase (RNA-containing) was generated after adding 1:5 bromo-chloro-propane to TRIzol and mixing. After centrifugation for $15 \mathrm{~min}$ at 12,000g, the RNAcontaining aqueous phase was recovered and mixed 1:2 with $70 \%$ 2-propanol. RNA was then precipitated by centrifugation for 5 min at 13,600 g, and the RNA pellet was cleaned twice with $75 \%$ Ethanol (in DEPC water). RNA was dried at room temperature until transparent and was resuspended in DEPC water. Finally, RNA was incubated for $10 \mathrm{~min}$ at $55^{\circ} \mathrm{C}$ to solubilize. RNA concentration and integrity were determined using the NanoDrop ND-1000 spectrophotometer (Thermo Scientific). RNA samples were stored at $-80^{\circ} \mathrm{C}$ until use.

500-1000 ng of RNA with an A260/A280 ratio ranging from 1.7 to 2.2 were converted to cDNA using the high-capacity RNA-to-cDNA ${ }^{\mathrm{TM}}$ kit (Applied Biosystems) after treatment with DNaseI (Qiagen) to remove any traces of genomic DNA that may 
have been recovered in the extraction step. The reaction conditions were: $10 \mathrm{~min}$ at $25^{\circ} \mathrm{C}, 120 \mathrm{~min}$ at $37^{\circ} \mathrm{C}$, and final $5 \mathrm{~min}$ at $85^{\circ} \mathrm{C}$. The samples were stored at $-20^{\circ} \mathrm{C}$ until use.

A total of 10 ng of cDNA was used for quantitative PCR (qPCR) in a total volume of $10 \mu \mathrm{l}$ with $2 \mathrm{X}$ AceQ SYBR qPCR Master Mix (Quimigen) and $500 \mathrm{nM}$ of forward and reverse primers, on a LightCycler 480 (Roche, Switzerland). qPCRprimers (IDT) were designed using Primer-BLAST (NCBI) sequences are detailed in Table 5 for rat samples and in Table 6 for mouse samples. The amplification conditions were determined by the primers to achieve amplification efficiency close to $100 \%$ and a single peak in melt-curve analyses. Each realtime PCR reaction was performed in triplicate. Amplification conditions were $95^{\circ} \mathrm{C} 3$ minutes, followed by 40 cycles of $95^{\circ} \mathrm{C}$ for 30 seconds, $60^{\circ} \mathrm{C}$ for 30 seconds, $72^{\circ} \mathrm{C}$ for 30 seconds, and a final extension at $72^{\circ} \mathrm{C}$ for 5 minutes. Peptidylprolyl Isomerase A (PPIA) and Glyceraldehyde-3-phosphate dehydrogenase (GAPDH) were used as housekeeping genes. The log fold change in mRNA expression was calculated from $2^{-\Delta \Delta C t}$ values relative to control simples (219) and ratio with housekeeping gene: $\left(2^{\mathrm{ctHK} / 2}\right.$ ctGENE).

Table 5. Sequences of Forward and Reverse primer for Rat genes

GENE 5'-3' PRIMER SEQUENCE

AKT1

Fw-GCACTTTCCCCAGTTCTCCTAC

Rw-GCCCACAGTAGAAACATCCTC 


\begin{tabular}{|c|c|}
\hline \multirow{2}{*}{ ARGI } & Fw- ACATTGGCTTGCGAGACGTA \\
\hline & Rw-ATCACCTTGCCAATCCCCAG \\
\hline \multirow{2}{*}{ CASPASE 1} & Fw-GACCGAGTGGTTCCCTCAAG \\
\hline & Rw-GACGTGTACGAGTGGGTGTT \\
\hline \multirow{2}{*}{ CCL2 } & Fw-TAGCATCCACGTGCTGTCTC \\
\hline & Rw-GAGCTTGGTGACAAATACTACAGC \\
\hline \multirow{2}{*}{ CCL3 } & Fw-CGGGTGTCATTTTCCTGACCA \\
\hline & Rw-GGAGGTTTGGGGGTTCCTTG \\
\hline \multirow{2}{*}{ CCL5 } & Fw-CATATGGCTCGGACACCACT \\
\hline & Rw-GACTGCAAGGTTGGAGCACT \\
\hline \multirow{2}{*}{ CD206 } & Fw-GTGGAGTGATGGAACCCCAG \\
\hline & Rw-CTGTCCGCCCAGTATCCATC \\
\hline \multirow{2}{*}{ CXCL10 } & Fw-CCGCATGTTGAGATCATTGCC \\
\hline & Rw-CTCTCTGCTGTCCATCGGTC \\
\hline \multirow{2}{*}{ GAPDH } & Fw-AGTGCCAGCCTCGTCTCATA \\
\hline & Rw-GGTAACCAGGCGTCCGATAC \\
\hline \multirow{2}{*}{ IL1及 } & Fw-CAGCTTTCGACAGTGAGGAGA \\
\hline & Rw-TTGTCGAGATGCTGCTGTGA \\
\hline \multirow{2}{*}{ IL6 } & Fw-TTTCTCTCCGCAAGAGACTTCC \\
\hline & Rw-TGTGGGTGGTATCCTCTGTGA \\
\hline \multirow{2}{*}{ IL10 } & Fw-CCTCTGGATACAGCTGCGAC \\
\hline & Rw-GTAGATGCCGGGTGGTTCAA \\
\hline \multirow{2}{*}{ IL12 } & Fw-AGAATGAGAGTTGCCTGGCT \\
\hline & Rw-AGTGCTGCATTTATGGCCTG \\
\hline \multirow{2}{*}{ IL18 } & Fw-TATCGACCGAACAGCCAACG \\
\hline & Rw-GATAGGGTCACAGCCAGTCC \\
\hline INOS & FW-GCCTAGTCAACTACAAGCCCC \\
\hline
\end{tabular}




\begin{tabular}{|c|c|}
\hline \multirow{3}{*}{ L-SELECTINE } & Rw-AGAAACTTCCAGGGGCAAGC \\
\hline & Fw-GGTACTAACAACCGCCACCA \\
\hline & Rw-CTCTAACGTGGGAGATGCCC \\
\hline \multirow{2}{*}{ МАРКЗ } & Fw-CACTGGCTTTCTGACCGAGT \\
\hline & Rw-GCCCACAGACCAGATGTCAA \\
\hline \multirow{2}{*}{ МАРК8 } & Fw-TGCTGGTGATAGATGCGTCC \\
\hline & Rw-CCAGACGTTGATGTACGGGT \\
\hline \multirow{2}{*}{ MHCII } & Fw-AGAGACCATCTGGAGACTTG \\
\hline & Rw-CATCTGGGGTGTTGTTGGA \\
\hline \multirow{2}{*}{ MYD88 } & Fw-AACCCAGAACCGAGGACCTA \\
\hline & Rw-TGGCTATGCGTGGTGAAGTG \\
\hline \multirow{2}{*}{ NFKB1A } & Fw-CTCAAGAAGGAGCGGTTGGT \\
\hline & Rw-CCAAGTGCAGGAACGAGTCT \\
\hline \multirow{2}{*}{ NLRP1 } & Fw-GCCTGGGACGAACACATCAT \\
\hline & Rw-TTCAAAGCAGGAAGCCAGTG \\
\hline \multirow{2}{*}{ NLRP3 } & Fw-TGCATGCCGTATCTGGTTGT \\
\hline & Rw-ATGTCCTGAGCCATGGAAGC \\
\hline \multirow{2}{*}{ RELA (P65) } & Fw-TGTATTTCACGGGACCTGGC \\
\hline & Rw-CAGGCTAGGGTCAGCGTATG \\
\hline \multirow{2}{*}{ SMAD3 } & Fw-CTGGGCAAGTTCTCCAGAGTT \\
\hline & Rw-GAAGGGCAGGATGGACGAC \\
\hline \multirow{2}{*}{ STAT1 } & Fw-GGAAGGGGCCATCACATTCA \\
\hline & Rw-CTGGAGACATGGGAAGCAGG \\
\hline \multirow{2}{*}{ STAT3 } & Fw-CCTGAAGCTGACCCAGGTG \\
\hline & Rw-TCCATGTCAAACGTGAGCGA \\
\hline \multirow{2}{*}{ TGF $\beta$} & Fw-CTGCTGACCCCCACTGATAC \\
\hline & Rw-AGCCCTGTATTCCGTCTCCT \\
\hline
\end{tabular}


TNFa

Fw-ATGGGCTCCCTCTCATCAGT

Rw-GCTTGGTGGTTTGCTACGAC

Table 6. Sequences of Forward and Reverse primer for Mouse genes

GENE 5'-3' PRIMER SEQUENCE

\begin{tabular}{|c|c|}
\hline \multirow{2}{*}{$\begin{array}{l}\text { ק3- } \\
\text { TUBULIN }\end{array}$} & Fw-TGAAGTCAGCATGAGGGAGA \\
\hline & Rw-GCCTGAATAGGTGTCCAAA \\
\hline \multirow{2}{*}{ ARGI } & Fw-CTGAGCTTTGATGTCGACGG \\
\hline & Rw-TCCTCTGCTGTCTTCCCAAG \\
\hline \multirow{2}{*}{ CCL2 } & Fw-TGCCCTAAGGTCTTCAGCAC \\
\hline & Rw-AAGGCATCACAGTCCGAGTC \\
\hline \multirow{2}{*}{ CCL3 } & Fw-TGCCAAGTAGCCACATCGAG \\
\hline & Rw-GAGATGGGGGTTGAGGAACG \\
\hline \multirow{2}{*}{ CCL5 } & Fw-TGCTCCAATCTTGCAGTCGT \\
\hline & Rw-GCAAGCAATGACAGGGAAGC \\
\hline \multirow{2}{*}{ CMYC } & Fw-TGAAGAACCAGAGAAGCCCA \\
\hline & Rw-CCTATTCAGCACGCTTCTCC \\
\hline \multirow{2}{*}{ CXCL10 } & Fw-ATGACGGGCCAGTGAGAATG \\
\hline & Rw-TCAACACGTGGGCAGGATAG \\
\hline \multirow{2}{*}{ CYCLIND1 } & Fw-AGTGCGTGCAGAAGGAGATT \\
\hline & Rw-CACAACTTCTCGGCAGTCAA \\
\hline \multirow{2}{*}{ DLX2 } & Fw-TGGGCTCCTACCAGTACCAC \\
\hline & Rw-TGGCTTCCCGTTCACTATTC \\
\hline \multirow{2}{*}{ FOXJ1 } & Fw-TTGACTGGGAGGCCATCTTT \\
\hline & Rw-AGGAAGGATGTGGCCAAGAA \\
\hline GAPDH & Fw-CGGTGCTGAGTATGTCGTGGAGT \\
\hline
\end{tabular}




\begin{tabular}{|c|c|}
\hline \multirow{3}{*}{ GFAP } & Rw-CGTGGTTCACACCCATCACAAA \\
\hline & Fw-AAGGTTGAATCGCTGGAGG \\
\hline & Rw-AGTCGTTAGCTTCGTGCTTG \\
\hline IL1及 & $\begin{array}{l}\text { Fw- } \\
\text { ACAGAATATCAACCAACAAGTGATATTCTC } \\
\text { Rw-GATTCTTTCCTTTGAGGCCCA }\end{array}$ \\
\hline \multirow{2}{*}{ IL10 } & Fw-AGGCGCTGTCATCGATTTCT \\
\hline & Rw-ATGGCCTTGTAGACACCTTGG \\
\hline \multirow{2}{*}{ INOS } & Fw-TGGCTCGCTTTGCCACGGAC \\
\hline & Rw-GCTGCGACAGCAGGAAGGCA \\
\hline \multirow{2}{*}{ NCAM1 } & Fw-CCGGTTCATAGTCCTGTCCA \\
\hline & Rw-CATTCACGATGCTCTGTCTGG \\
\hline \multirow{2}{*}{ NEUROG1 } & Fw-GACAGACGGACAGGAGGTTT \\
\hline & Rw-ACATCACTCAGGAGACCAGC \\
\hline \multirow{2}{*}{ NG2 } & Fw-ACAGCTCCTGCCTCCTTCTTC \\
\hline & Rw-TCAACAGACAGCACAGCCCAG \\
\hline \multirow{2}{*}{ NOTCH1 } & Fw-GAAAGAGGGCATCAGAGGGT \\
\hline & Rw-CTTCGCACCTCCCTCCATT \\
\hline \multirow{2}{*}{ OLIG1 } & Fw-CCCACCTGTTTAGAGCCAGA \\
\hline & Rw-AAGCATGCCAGGAAACCAAG \\
\hline \multirow{2}{*}{ OLIG2 } & Fw-ATGGAGAGATGCGTTCGTTC \\
\hline & Rw-CCAGACAGGGAGTCAATCTTT \\
\hline \multirow{2}{*}{$\mathbf{P 2 1}$} & Fw-GCCTTAGCCCTCACTCTGTG \\
\hline & Rw-AGGGCCCTACCGTCCTACT \\
\hline \multirow{2}{*}{ PDGFR $\alpha$} & Fw-ACGTTCAAGACCAGCGCGAGTT \\
\hline & Rw-GCAGCACATTCATACTCTCCA \\
\hline PPIA & Fw-CGCGTCTCCTTCGAGCTGTTT \\
\hline
\end{tabular}




\begin{tabular}{|c|c|}
\hline \multirow{3}{*}{ SOX2 } & Rw-TGTAAAGTCACCACCCTGGCACA \\
\hline & Fw-TTAССТСТТССТСССАСТССА \\
\hline & Rw-CCCTCCCAATTCCCTTGTAT \\
\hline \multirow{2}{*}{ SOX9 } & Fw-CAAGAACAAGCCACACGTCA \\
\hline & Rw-GTGGTCTTTCTTGTGCTGCA \\
\hline \multirow{2}{*}{ SOX10 } & Fw-TGGGCAAGGTCAAGAAGGAA \\
\hline & Rw-TTGTGGAGGTGAGGGTACTG \\
\hline \multirow{2}{*}{ TLR1 } & Fw-ATGATTCTGCCTGGGTGAAG \\
\hline & Rw-TCTGGATGAAGTGGGGAGAC \\
\hline \multirow{2}{*}{ TLR2 } & Fw-CTCCCACTTCAGGCTCTTTG \\
\hline & Rw-AGGAACTGGGTGGAGAACCT \\
\hline \multirow{2}{*}{ TLR3 } & Fw-AGCTTTGCTGGGAACTTTCA \\
\hline & Rw-GAAAGATCGAGCTGGGTGAG \\
\hline \multirow{2}{*}{ TLR4 } & Fw-AAGAGCCGGAAGGTTATTGTG \\
\hline & Rw-CCCATTCCAGGTAGGTGTTTC \\
\hline \multirow{2}{*}{ TLR6 } & Fw-ACACAATCGGTTGCAAAACA \\
\hline & Rw-GGAAAGTCAGCTTCGTCAGG \\
\hline \multirow{2}{*}{ TLR8 } & Fw-GGCACAACTCCCTTGTGATT \\
\hline & Rw-CATTTGGGTGCTGTTGTTTG \\
\hline \multirow{2}{*}{ TLR9 } & Fw-GCTTTGGCCTTTCACTCTTG \\
\hline & Rw-AACTGCGCTCTGTGCCTTAT \\
\hline \multirow{2}{*}{ TNF $\alpha$} & Fw-TTCTATGGCCCAGACCCTCA \\
\hline & Rw-GTTTGCTACGACGT \\
\hline
\end{tabular}




\section{WESTERN BLOT: PROTEIN EXTRACTION AND IMMUNOBLOTTING}

Spinal cord tissues were homogenized in liquid nitrogen for protein extraction. Total protein was extracted from cell cultures and tissue using lysis buffer for $30 \mathrm{~min}$ at $4^{\circ} \mathrm{C}$. Every 5 $10 \mathrm{~min}$, samples were vortex and after $30 \mathrm{~min}$, samples were centrifuged for $15 \mathrm{~min}$ at $13,000 \mathrm{~g}$ to recover proteins from the supernatant. Protein concentration was determined using the bicinchoninic acid colorimetric assay (BCA-Protein Assay Kit; Thermo Fisher Scientific) and measuring absorbance at $562 \mathrm{~nm}$. For sample preparation, 20-30 ug of protein were added to $4 \mathrm{X}$ Laemmli sample buffer and 50mM Dithiothreitol and incubated for $5 \mathrm{~min}$ at $95^{\circ} \mathrm{C}$ in a thermoblock (Thermomixer Compact, Eppendorf, Germany). Equal amounts of lysates were prepared with reducing Laemmli buffer, separated on 12\% SDSpolyacrylamide gel electrophoresis (PAGE) gels for $120 \mathrm{~min}$ at $100 \mathrm{~V}$ RT, and transferred to methanol-activated polyvinylidene difluoride (PVDF) membranes for $90 \mathrm{~min} 220 \mathrm{mAMP} / \mathrm{gel}$ RT. Staining with Red Ponceau was performed for $5 \mathrm{~min}$ after transfer to ensure that the transfer step was performed adequately.

Membranes were blocked with 5\% bovine serum albumin in Tris-buffered Saline with $0.1 \%$ Tween-20 for $1 \mathrm{~h}$ at room 
temperature and incubated at $4{ }^{\circ} \mathrm{C}$ overnight with the primary antibody (Table 7) solutions. After washing, the membranes were incubated with secondary antibodies conjugated with HRP. To ensure loading with equal amounts of protein lysates, blots were incubated with an antibody against $\alpha$ Tubulin (1:10,000, SigmaAldrich), GAPDH (1:5000, Merck), and/or $\beta$ Actin (1:1000, Sigma-Aldrich) as loading controls. Signal detection was performed with an enhanced chemiluminescence kit (ECL Plus Western blotting detection reagent - GE Healthcare, Piscataway Township, NJ, USA), and bands were developed using Q9 Alliance. Images from membrane development were analyzed by band densitometry with ImageJ Software (Version 1.50i, https://imagej.nih.gov/ij/).

Table 7. Primary antibodies for Western Blot assays.

\begin{tabular}{c|lll} 
ANTIBODY & HOST & KDA & PURCHASED FROM \\
\hline BCL2 & Mouse & 26 & Santacruz Biotechnology \\
BDNF & Rabbit & $14-28$ & Abcam \\
CASPASE1 & Rabbit & 50 & Cell Signalling \\
CASPASE3 & Rabbit & 35 & Cell Signalling \\
C-FOS & Rabbit & 50 & Abcam \\
ED1 & Mouse & 9 & Millipore \\
ERK & Mouse & $42-44$ & Santacruz Biotechnology \\
IBA1 & Rabbit & 17 & Wako \\
IL1 & Mouse & 31 & Cell Signalling
\end{tabular}




\begin{tabular}{c|lll} 
INOS & Rabbit & 130 & Abcam \\
IRF1 & Mouse & 48 & Santacruz Biotechnology \\
JNK & Rabbit & 46 & Abcam \\
P38 & Rabbit & 40 & Cell Signalling \\
P65 & Mouse & 65 & Santacruz Biotechnology \\
P-ERK & Rabbit & $42-44$ & Cell Signalling \\
P-JNK & Mouse & 46 & Santacruz Biotechnology \\
P-P38 & Rabbit & 40 & Cell Signalling \\
P-P65 & Rabbit & 65 & Santacruz Biotechnology \\
STAT3 & Mouse & 93 & Santacruz Biotechnology \\
TLR2 & Rabbit & 90 & Santacruz Biotechnology \\
TLR4 & Mouse & 96 & Proteintech
\end{tabular}

\section{MICROSCOPY TECHNIQUES}

Immunofluorescence images from in vitro experiments were taken by Leica IM 5004.0 (Leica, Bensheim, Germany) and using a Zeiss ApoTome microscope (Carl Zeiss) for neurosphere stacks. Magnification of images used a Leica TCS SP8 confocal microscope. Tissue immunofluorescence images were scanned on the Aperio Versa scanner (Leica Biosystems). The brightfield images of cells were taken with a Leica IM 5004.0 (Leica, Bensheim, Germany). 


\section{FIGURE LAYOUT}

The graphs shown were plotted in Prism-GraphPad 8 software (https://www.graphpad.com/). The design and assembly of the figures were conducted with Adobe Illustrator CC 2018. The images and diagrams presented were modified from images from Biorender Basic (https://app.biorender.com/).

\section{STATISTICAL ANALYSIS}

All experimental data were collected from at least three independent in vitro experiments or three different animals for tissue analysis, and results were reported as the mean \pm the standard error of the mean (S.E.M.) as indicated for each set of data. For the comparisons between two groups of values, the statistical analysis of the results used the Student's t-test for normally distributed data. Results between groups were first assessed for normality using the Shapiro-Wilk test and then analyzed using one-way ANOVA, with appropriate corrections such as Tukey's post hoc tests used for comparisons. Statistical analyses were performed using GraphPad software. Differences were considered significant at $* \mathrm{p}<0.05, * * \mathrm{p}<0.01, * * * \mathrm{p}<0.001$ and $* * * * p<0.0001$. All statistics and post hoc tests are stated in the text, and corrections for multiple comparisons performed where appropriate. Prism-GraphPad 8 software was used for statistical analysis. 


\section{RESULTS}


The results presented in this doctoral thesis are divided into three chapters:

* The experimental research presented within $\underline{\text { Chapter } 1 \text { has }}$ been carried out in CIPF resulting in the publication "Sanchez-Petidier M, Guerri C, Moreno-Manzano V. Toll-Like Receptors 2 and 4 Differentially Regulate the Self-Renewal and Differentiation of Spinal Cord Neural Precursor Cells. Stem Cell Research and Therapy. 2022" which is under revision in the journal Stem Cell Research and Therapy.

The experimental research presented within Chapter 2 has been carried out CIPF resulting in the publication "Sánchez-Petidier M, et al. Role of TLR2 and TLR4 in $N P C$ transplantation after spinal cord injury" which manuscript is in preparation.

The experimental research presented within Chapter 3 has been carried out in CIPF as part of the publication "Francos-Quijorna I, Sánchez-Petidier M, Burnside E, Torres-Espin A, Marshall L, Verhaagen J, MorenoManzano V, Bradbury E. Chondroitin sulfate proteoglycans prevent immune cell phenotypic conversion and inflammation resolution after spinal cord injury via TLR4. Nature Communications. 2022" in collaboration with Professor Elizabeth Bradbury's group in King's College of London, which is under revision in the journal Nature Communications. 


\section{CHAPTER 1}

TOLL-LIKE RECEPTORS 2 AND 4 DIFFERENTIALLY REGULATE THE SELFRENEWAL AND DIFFERENTIATION OF SPINAL CORD NEURAL PROGENITOR CELLS 


\subsection{Introduction}

The adult rodent spinal cord contains a multipotent and self-renewing population of NPCs $(220,221)$ located around the central ependymal canal (222). Adult spinal cord NPCs are derived from ependymal cells $(64,223)$. Under physiological conditions, NPC proliferation occurs during embryogenesis and in the early postnatal period (224). Spinal cord NPCs can differentiate into astrocytes, oligodendrocytes, and, to a lesser extent, neurons (225).

Interestingly, a study from Mothe and Tator using a rat injury model reported that endogenous spinal cord NPCs proliferated, migrated from the central canal, and differentiated primarily into astrocytes (226), thereby suggesting their therapeutic potential. Subsequent studies by the Frisen laboratory using a FoxJ1-GFP reporter transgenic mouse NPC line detailed their activation, proliferation, and contribution to the injured spinal cord (227). The presence of adult spinal cord NPCs suggests that endogenous stem cell-associated mechanisms could be exploited to repair spinal cord lesions. Interestingly, NPCs activated by injury proliferate ten times faster in vitro than those isolated from healthy animals $(201,228)$. Moreover, NPCs preferentially differentiate into the cell types necessary to rescue neuronal activity (e.g., OPCs or motoneurons), and ectopic transplantation immediately after injury led to functional 
recovery (200). Unfortunately, humans lack this endogenous repair mechanism. Paniagua-Torija et al. recently demonstrated the atrophied nature of the human spinal cord ependymal region and a lack of proliferative response of ependymal-like cells to injury (229).

High content transcriptional analysis of NPCs activated by SCI exhibited induced expression of JAK/STAT and MAPK pathways compared with NPC from healthy rats (200). In addition, NPC transplantation into an SCI led to lower levels of Connexin50 expression (ion channels that influence the secondary expansion of traumatic SCI) and purinergic receptor (P2X4 and P2X7) expression, indicating that NPCs possesses distinct mechanisms to enhance tissue regeneration $(228,230)$.

In the healthy adult human and mouse spinal cord, studies have highlighted TLR2 and TLR4 as the most highly expressed members of the TLR family $(123,231)$ and the significant overexpression of TLR2 and TLR4 following SCI in experimental rodent models $(122,232)$. The activation of TLR2 signaling by intrathecal or intramedullary injection of zymosan in the spinal cord produces demyelination, axonal damage, and astrocytic activation (233), which has been attributed to the activation and infiltration of resident microglia and the activation of circulating monocytes, mimicking the inflammatory responses observed after SCI $(63,233)$. However, studies have noted that the absence of TLR2 (122) or TLR4 (141) limits spontaneous 
regeneration, impairs re-myelination, and sustains locomotor deficits after SCI due, at least in part, to reduced iron metabolism and unbalanced growth factors delivery, which impair OPC maturation (141).

We currently lack any information regarding the expression or function of TLRs in spinal cord-derived NPCs. In the brain, NPCs at the embryonic $(78,79)$ and adult stages $(234)$ express TLR2 and TLR4. Both have distinct and opposing roles in NPC proliferation and differentiation in vitro and in vivo. Activation of NPCs with specific TLR2 ligands such as Pam2CSK4 (a synthetic diacylated lipopeptide) inhibits the formation of NPC-neurospheres in vitro; however, TLR2 loss does not impact the proliferative capacity of NPCs (78). TLR4 activation by LPS also decreases the proliferation of embryonic NPCs (79) and adult hippocampal NPCs (65). Furthermore, TLR4-deficient mouse-NPCs exhibit increased proliferation (65). Activation by pro-inflammatory stimuli such as TNF $\alpha$ and INF $\gamma$ increases TLR2 and TLR4 expression and induces TNF $\alpha$ production in NPCs, suggesting the priming of NPCs to participate in cytokine production during neuroinflammatory or traumatic conditions (235).

The neurogenesis and gliogenesis support the lifelong plasticity of the CNS in response to extrinsic and intrinsic changes, and NPCs play a crucial role. TLR2 deficiency or 
activation in embryonic NPCs from developmental stages E12 or E15 do not affect differentiation to neurons or astrocytes (78); however, TLR2 deficiency in adult-derived NPCs decreases their neuronal differentiation while increasing their astrocytic differentiation. In contrast, TLR4 deficiency in embryonic and adult NPCs increases differentiation to neurons, and LPSmediated activation decreases differentiation to neurons (65). Taken together, these results suggest the requirement for TLR2 for proper differentiation to neurons, but that TLR4 restricts neurogenesis. While there exist studies of the roles of TLR2 and TLR4 in brain NPCs, we know little regarding their role in spinal cord NPCs.

Chapter 1 examines the role of TLR2 and TLR4 in spinal cord NPCs, with a focus on the neonatal stage and non-injured tissue. 
Chapter 1: Introduction

CB57/BL6 post natal mice

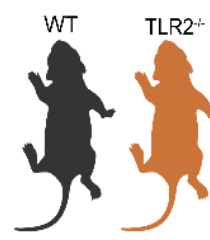

Tissue Outcomes

Spinal cord sections
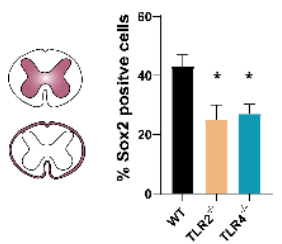

Spinal Cord
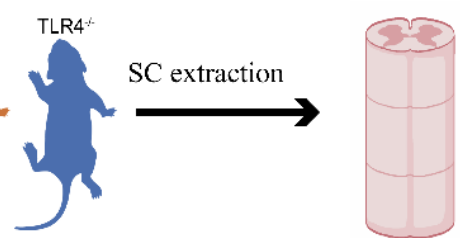

NPC Isolation

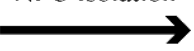

3D-culture like

neurosphere

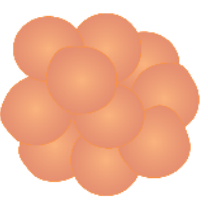

\section{Cells Outcomes}

Growth conditions

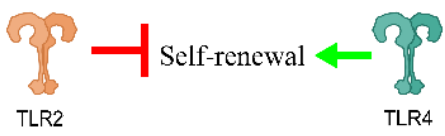

Differentiation conditions

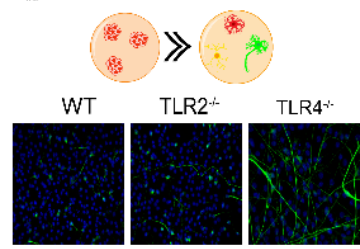

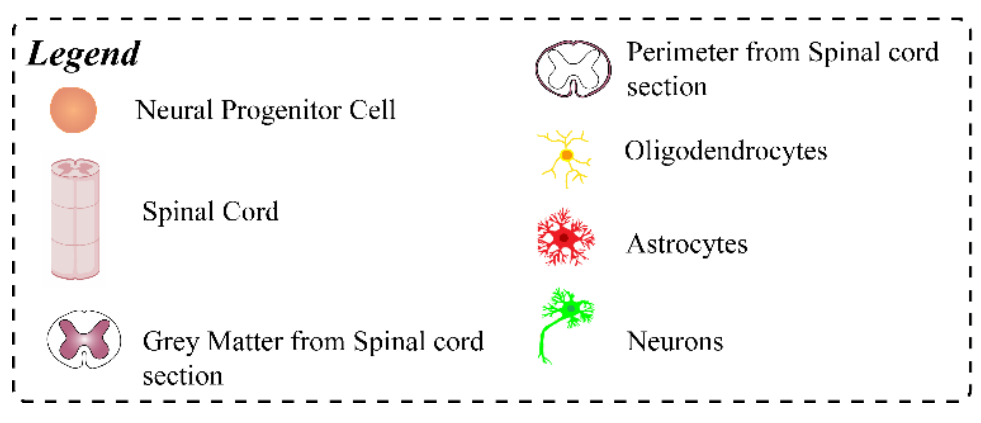

Figure 11. Chapter 1 Graphical Abstract 


\subsection{Results}

\subsubsection{TLR2 and TLR4 Expression Maintain the NPC Population in the Postnatal Mouse Spinal Cord}

Expression of TLRs in adult spinal cord has been reported by several authors (review by (232)). In postnatal (p5-7) mouse spinal cord we observed that TLR3 has a higher expression mostly because it is the most abundant TLR on astrocytes. Next, we found that TLR1, 2 and 4 have similar expression, the second most expressed TLRs (Figure 12, A). TLR2 and TLR4 displayed similar expression levels in wild-type (WT) mouse neonatal spinal cord extracts at the mRNA (Figure 12, B) and protein levels (Figure 12, C). Moreover, immunohistochemical analysis of spinal cords provided evidence that most TLR2-expressing cells (orange) co-expressed TLR4 (green) around the central canal (CC), as shown in the representative images (Figure 12, D). 
A)

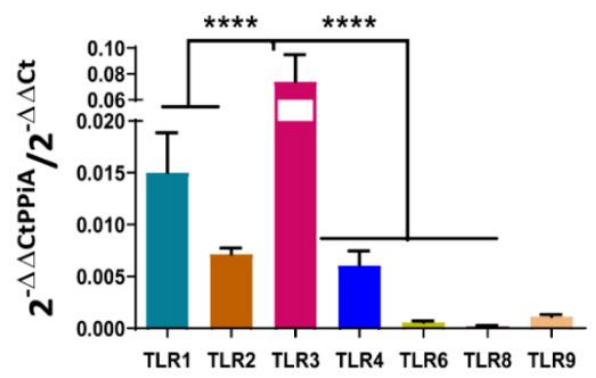

B)

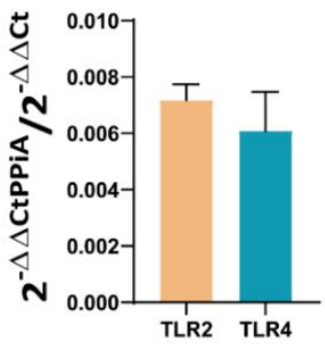

C)

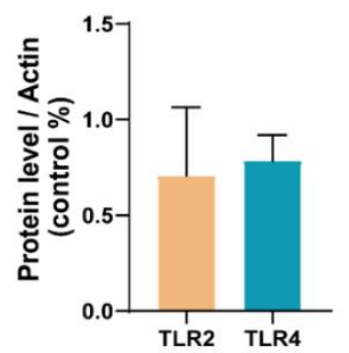

Spinal Cords

TLR2

Actin
D)

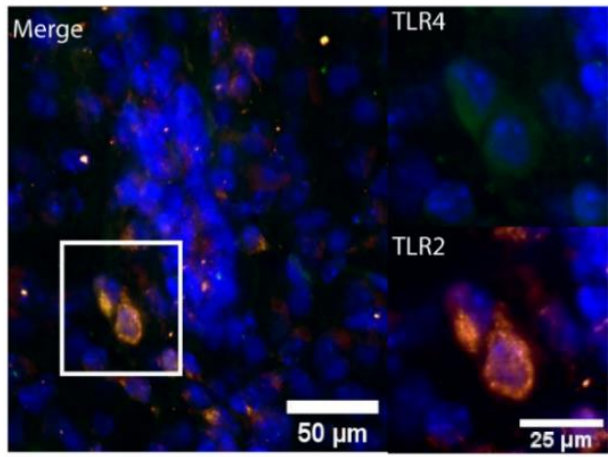

Figure 12. TLR2 and TLR4 Expression in the neonatal mouse spinal cord.

A) Gene expression analyses of TLRs in the spinal cord od WT neonatal mice. Data shown as mean \pm SEM ( $\mathrm{N}=6$ per group). Results assessed for normality using the Shapiro-Wilk test and one-way ANOVA with Tukey post hoc test; $* * * * \mathrm{p}<0.0001$. B) Amplification of gene expression analysis of TLR2 and TLR4. C) Representative Western blot and quantification of protein levels of TLR2 and TLR4 in the spinal cord tissue of WT neonatal mice. $\beta$ - actin used as a total protein loading control. Data shown as mean \pm SEM $(\mathrm{N}=3$ per group). D) Representative image showing double immunoreactivity (merge) for TLR2 (orange) or TLR4 (green) and DAPI (blue -for nuclei counterstaining) in spinal cord coronal slices. A magnified view of the indicated area with a white square for each staining on the right. 
To further investigate the role of TLR2 and TLR4 in neonatal mouse spinal cord-resident NPCs, we explored the expression of Sox2, a neurogenic transcription factor (236) and known stem cell marker (237). NPCs express Sox 2 to regulate the specification of early neural lineages and brain development $(238,239)$. In the early postnatal WT mouse spinal cord, we observed Sox 2 expression within the CC (Figure 13, A) in cells homogeneously distributed dorsally and ventrally within the grey matter at the mantle (MT) area (Figure 13; MT) and within the lining along the cord perimeter (PM) in the white matter (Figure 13). Interestingly, the deletion of TLR 2 or TLR 4 significantly diminished the total number of Sox2-positive cells (Figure 13, B). When we closely inspected Sox2-expressing cells, we found two distinct expression patterns - nuclear Sox2 expression, corresponding to dividing progenitors NPCs (240), previously reported as potential OPC (241) and mature astrocytes (Figure 13, C, inset *) and cytoplasmic Sox 2 expression, corresponding to migrating and nondividing neuroblasts (242) and mature neurons (243) (Figure 13, C, inset \#). Our analysis revealed that TLR 2 or TLR4 loss only affected the number of cells with nuclear Sox2 expression (Figure 13, C; solid blue bar). An analysis of the number of astrocytes and early OPCs (by GFAP and Olig2 staining, respectively) failed to demonstrate any significant differences in any of the samples (Figure 13, E). Likewise, all Sox2-positive cells located in the cord perimeter/meningeal zone (244), displayed nuclear Sox2 expression, and here we found a 
significant impact of TLR2 or TLR4 loss - a significant decrease in the number of this NPC population (Figure 13, D, right panel), suggesting that decreases in SOX2-positive cells correspond to the number of precursors cells. We observed the vast majority of cells with cytoplasmic Sox2 expression located in the grey matter (Figure 13, D, left panel, blue striped bar) co-existing alongside cells with nuclear Sox 2 expression (Figure 13, D, left panel, solid blue bar). Cytoplasmic SOX2 expression colocalized with NeuN-positive cells, corresponding to mature neurons from the spinal cord. An analysis of NeuN levels demonstrated a significant reduction in the total number of neurons in TLR2 ${ }^{-/-}$but not TLR $4^{-/-}$mouse neonatal spinal cords compared to WT mice (Figure 13, E). Finally, an analysis of cell proliferation within the spinal cords of WT, TLR2 $2^{-/-}$, and TLR $4^{-/-}$ postnatal mice via Ki67 immunostaining failed to find any significant differences (Figure 13, F), suggesting that the decreased number of SOX2-expressing proliferating cells fails to significantly affect overall proliferative activity at the postnatal stage. 
A)
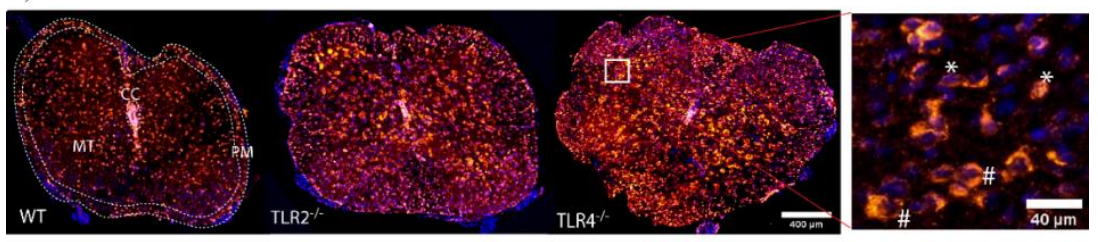

B)

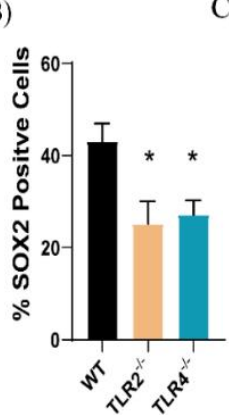

E)

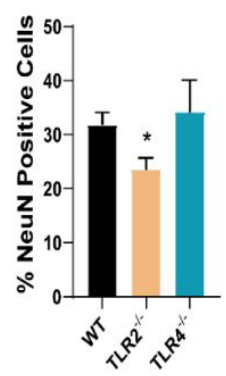

C)
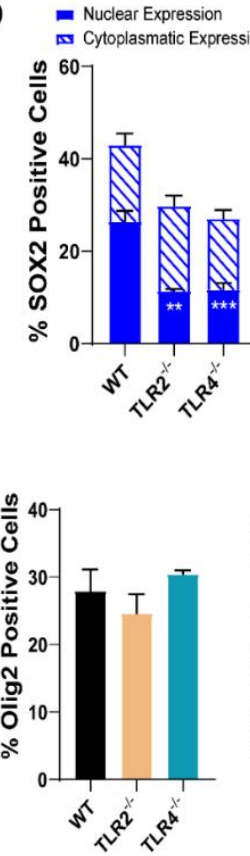

D)
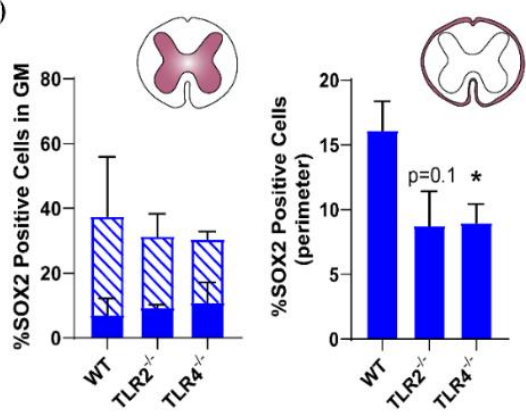

F)

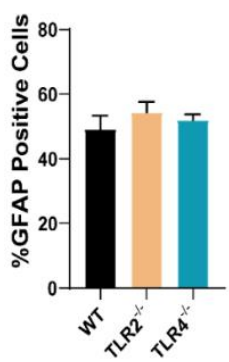

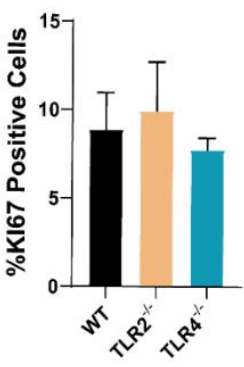

Figure 13. Analysis of cell fate on Spinal Cord from WT and TLR2 and TLR4 Knockout Mice. A) Left panel: Representative immunofluorescence images of SOX2 (orange) and DAPI (blue) in spinal cord coronal sections from WT, TLR2 ${ }^{-/-}$, and TLR $4^{-/-}$mice; Right panel: magnified view of the area indicated with a white square to show the nuclear $(*)$ or cytoplasmic (\#) subcellular expression of Sox2. B) Quantification of Sox2-positive cells expressed as a percentage of the total number of cells. C) Quantification of nuclear (full) or cytoplasmic (striped) Sox2-expressing cells as a percentage of the total number of cells in the entire spinal cord area. D) Quantification of nuclear (full) or cytoplasmic (striped) Sox2-expressing cells as a percentage of the total 
number of cells in the grey matter (left) and white matter at the PM (right). E) Quantification of NeuN-positive cells, Olig2-positive cells, and GFAPpositive cells expressed as a percentage of the total number of cells in the spinal cord coronal sections. F) Quantification of \% of cells positive for KI67. Data shown as mean \pm SEM ( $\mathrm{N}=5$ per group). Results assessed for normality using the Shapiro-Wilk test and one-way ANOVA with Tukey post hoc test; $* \mathrm{p}<0.05, * * \mathrm{p}<0.01$, or $* * * \mathrm{p}<0.001$ vs. WT.

Overall, these studies prompted us to undertake a more detailed in vitro analysis of in vitro expanded NPCs isolated from the spinal cords of WT, TLR2 $2^{-/}$, and TLR $4^{-/-}$mice to decipher the specific roles of these two TLRs in NPC self-renewal and differentiation.

\subsubsection{TLR Expression by in vitro-Expanded NPCs Isolated from the Postnatal Mouse Spinal Cord}

We next explored the relative expression of TLR2 and TLR4 by in vitro-expanded NPCs derived from mouse neonatal spinal cords (schematic representation of the NPC in vitro expansion procedure shown in Figure 14, A. Immunofluorescence analysis confirmed that NPCs co-express TLR2 and TLR4 (Figure 14, B). We found similar levels of mRNA (Figure 14, C) and protein (Figure 14, D) expression for TLR2 and TLR4 in WT NPCs. Next, we explored MyD88/TRIFmediated responses of TLRs in WT NPCs upon stimulation with $50 \mathrm{ng} / \mathrm{ml}$ of LPS for 30 or 60 minutes (Figure 14, E). All three tested downstream mediators of TLR2 and TLR4 (induced nitric 
oxide synthase (iNOS), phosphorylated extracellular signalregulated kinase (pERK), and IRF1), which all displayed maximal activation (as measured by an increase in protein levels for iNOS and IRF1 and phosphorylation of ERK) 30 minutes after stimulation followed by decreased activation after another 30 minutes, as previously described in other cell types $(245,246)$. These data provided evidence for the responsiveness and functionality of TLR2 and TLR4 to LPS stimulation in in vitroexpanded WT NPCs derived from mouse neonatal spinal cords.

We also evaluated the expression of the TLR family members in NPCs isolated from the spinal cords of TLR2 $2^{-/-}$and $\mathrm{TLR}^{-/-}$neonatal mice. Our findings confirmed the lack of TLR2 and TLR4 expression in TLR2 ${ }^{-/-}$and TLR $4^{-/-}$mice, respectively, and additionally demonstrated that TLR2 loss significantly reduced the expression level of TLR1, TLR6, TLR8, and TLR9, but not TLR3 and TLR4, and that TLR4 deletion significantly reduced the expression of TLR 1 and increased the expression of TLR9 (Figure 14, F). 
A)

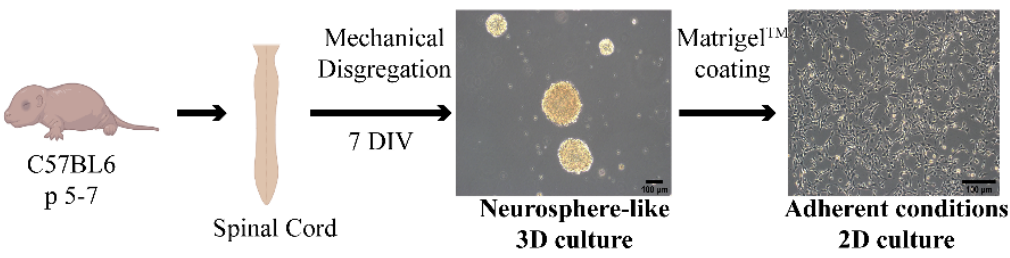

B)

C)

D)

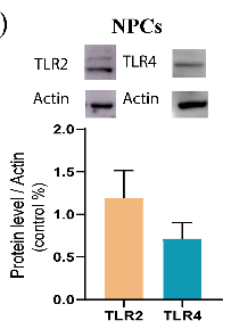

E)
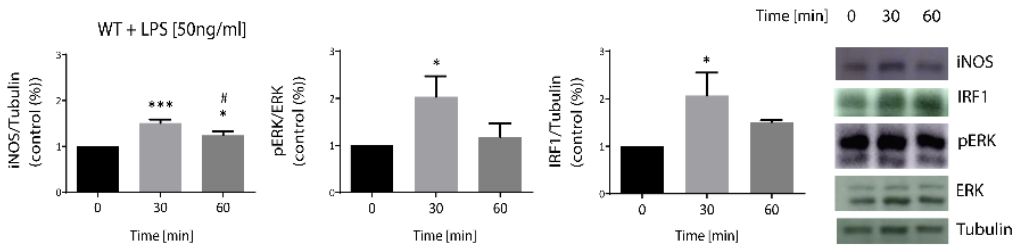

F)
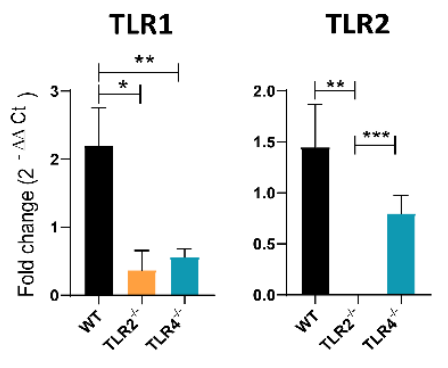

TLR3

TLR4

TLR6

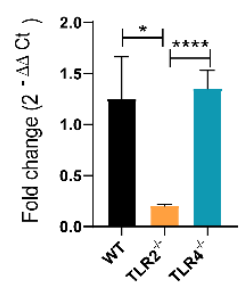

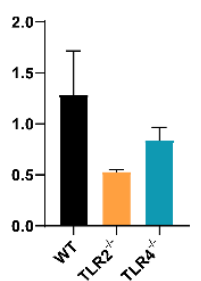

TLR8

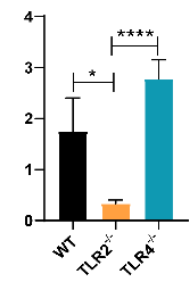

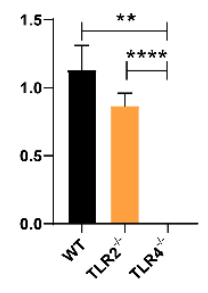

TLR9

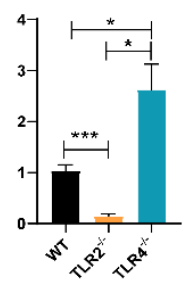

Figure 14. TLR2 and TLR4 Expression by in vitro-expanded Spinal Cord NPCs. A) Schematic representation of NPC extraction from neonatal mouse spinal cords and their culture in both neurosphere-like-3D and adherent 
conditions. B) Representative confocal images showing the expression of TLR4 (green), TLR2 (red), and the co-expression (merge) in WT NPCs grown under adherent conditions. C) Gene expression analysis of TLR2 and TLR4 in WT NPCs. D) Representative Western blot and quantification of TLR2 and TLR4 protein expression in WT NPCs grown under adherent conditions. E) Densitometric analysis Western blot analysis of iNOS, pERK, and IRF1 levels in response to LPS $(50 \mathrm{ng} / \mathrm{ml})$ stimulation for 0,30 , or $60 \mathrm{~min}$ in WT NPCs grown under adherent conditions and a representative Western blot. Data shown as mean \pm SEM $(n=4$ per group) compared with the control group $(0$ min), while two-tailed unpaired t-test evaluated significant differences; $* \mathrm{p}>0.05, * * * \mathrm{p}<0.001$ vs. 0 min.; (F) Gene expression analysis of select TLRs in WT, TLR2 ${ }^{-/}$, and TLR4 ${ }^{--}$NPCs. Data shown as mean \pm SEM $(n=6$ per group) and two-tailed unpaired t-test evaluated significant differences; $* \mathrm{p}>0.05, * * \mathrm{p}<0.01, * * * \mathrm{p}<0.001, * * * * \mathrm{p}<0.0001$ as indicated.

\subsubsection{TLR2, but not TLR4, Regulates the Self- renewal of in vitro-Expanded NPCs Isolated from the Postnatal Mouse Spinal Cord}

We next explored whether TLR2 or TLR4 expression contributed to the FOXJ1 ependymal precursor cell population. FOXJ1, a transcription factor involved in ciliogenesis (247) - is considered a marker of fully differentiated and ciliated ependymal progenitor cells lining the $\mathrm{CC}$ that can divide and differentiate in postnatal periods $(227,248)$. However, we did not find significant differences in the number of FoxJ1-positive cells between WT, TLR2 ${ }^{-/-}$, and $\mathrm{TLR}^{-/-}$mice, as evidenced in the representative high magnification images of the CC (Figure 15, A, green). All FOXJ1-positive cells colocalized with SOX2, but 
not all SOX2-positive cells express FOXJ1 due to the existence of other progenitors populations (e.g., glial progenitors) in the $\mathrm{CC}$ (249).

We further investigated the potential role of TLR2 and TLR4 in the self-renewal and proliferation of NPCs. In vitro expanded neonatal spinal cord NPCs continue expressing Sox2 (Figure 15, B, orange) for the continuation of cell proliferation (250), maintenance of neural progenitor identity, and inhibition of precocious differentiation (251). Furthermore, NPCs isolated from WT, TLR $2^{-/-}$, or TLR $4^{-/-}$mice and cultured as neurospheres also expressed FoxJ1 (Figure 15, B, green) at a similar level (mRNA -Figure 15, C, the total number of total positive cells Figure 15, D). We did discover a significant difference in Sox2positive cells depending on their subcellular location. TLR4 deletion significantly reduced the number of nuclear expressingSox 2 cells compared to WT or TLR2 ${ }^{-/-}$NPCs (Figure 15, E). This result agrees with the data found in the spinal cord tissues (Figure 13, C) in TLR $4^{-/-}$spinal cords, but differs from the data found for $\mathrm{TLR}^{-/-}$spinal cords. 
A)
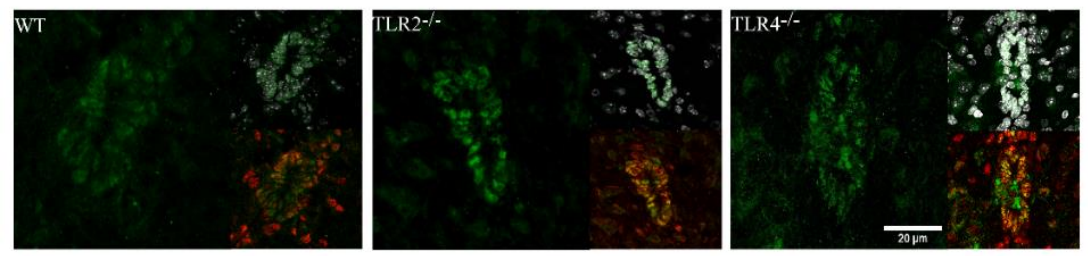

B)

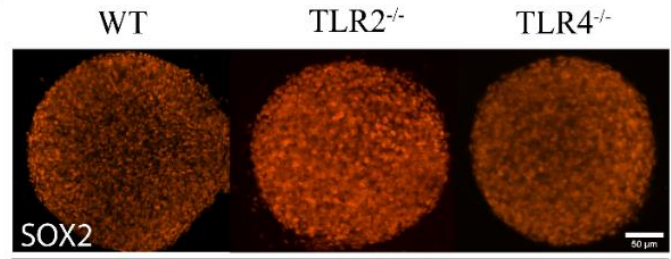

C)
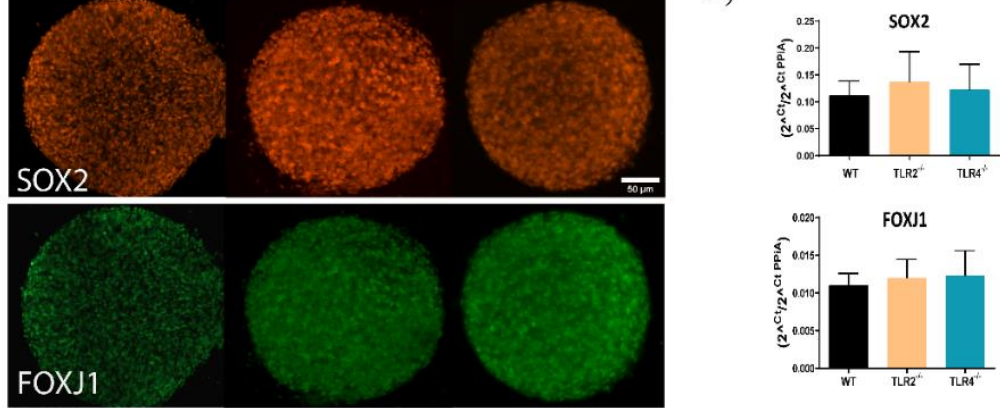

D)

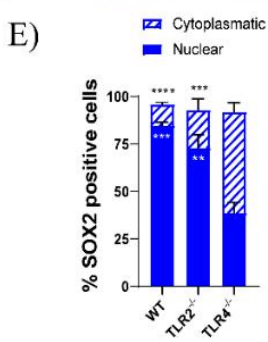

Figure 15. FOXJ1 and SOX2 positive cells in CC and neurospheres derived from neonatal mice. A) Representative immunostaining images of the CC of WT, TLR2 ${ }^{-/-}$and TLR4 ${ }^{-/-}$neonatal mouse spinal cords. For each genotype - Main large image - FOXJ (green); Small upper right image DAPI/FOXJ1 merge (white); Small lower right - SOX2/FOXJ1 merge (red). B) Representative images of immunofluorescence assay for Sox2 (upper panels, orange) and FoxJ1 (lower panels, green) in neurospheres formed using WT, TLR2 ${ }^{-/-}$, and TLR4 ${ }^{-/-}$NPCs. C) Gene expression analysis of Sox2 and Foxj1. Data shown as mean \pm SEM ( $\mathrm{N}=6$ per group). D) Quantification of FoxJ1-positive cells by immunoassay expressed as the percentage of total 
DAPI-positive cells. E) Quantification of Sox2-positive cells represented as nuclear (full) or cytoplasmic expression (striped). Black stars (*) vs. TLR4 ${ }^{-/-}$ for cytoplasmic Sox2 and white stars (*) vs. TLR4 ${ }^{-/-}$for nuclear Sox2. Data shown as mean \pm SEM ( $N=4$ per group). Results assessed for normality using the Shapiro-Wilk test and one-way ANOVA with Tukey post hoc test; * $\# \mathrm{p}<0,05, * * \# \# \mathrm{p}<0.01, * * * \# \# \mathrm{p}<0.001, * * * * \mathrm{p}<0.0001$.

We also evaluated the expression of marker genes preferentially expressed in immature NPCs in WT, TLR2 ${ }^{-/}$, or $\mathrm{TLR}^{-/-}$NPCs to evaluate whether deletion of TLR2 or TLR4 could influence early glial (SOX9, Olig1, PDGFR $\alpha$ ) or neuronal determination (NOTCH1, DLX2, NCAM1). However, we failed to find any difference in expression for these marker genes, suggesting TLR2 and TLR4 do not significantly influence NPC identity at the early postnatal stage (Figure 16, A). We next evaluated the ability of $\mathrm{TLR}^{-/-}$and $\mathrm{TLR}^{-/-} \mathrm{NPCs}$ to form primary neurospheres to explore their self-renewal capacity (252) (Figure 16, B). Overall, TLR2 ${ }^{-/-}$NPCs formed significantly larger but less numerous neurospheres than WT and TLR4 ${ }^{-/-}$NPCderived neurospheres, indicating the preferential formation of primary neurospheres and enhanced self-renewal. Meanwhile, TLR $^{-/-}$NPCs formed significantly smaller and more numerous neurospheres, indicating the rapid formation of secondary neurospheres and limited self-renewal. We also studied proliferation via BrdU incorporation and KI67 immunostaining in WT, TLR2 ${ }^{-/}$, and TLR4 ${ }^{-/}$NPCs grown under adherent conditions, finding that only TLR2 deletion significantly 
increased NPC proliferation (Figure 16, C). Analysis of phospho-H2AX levels, which mark cells undergoing mitotic stress (253), revealed a significantly higher number of positive cells in TLR2 ${ }^{-/-}$NPCs compared to WT and TLR4 ${ }^{-/-}$NPCs (Figure 16, D, representative images, right and graph, left). $\mathrm{TLR}^{-/-}$NPCs also displayed a higher level of cMyc gene expression than TLR2 ${ }^{-/}$NPCs (Figure 16, E, left), indicative of enhanced cell cycle activity. Analysis of P21 expression found significantly lower gene expression levels in TLR4 $4^{-/}$NPCs than WT NPCs, suggestive of a potentially deregulated cell cycle (Figure 16, E, right); however, population doubling level (PDL) analysis suggested a reduction in growth for TLR $4^{-/-}$NPCs only (Figure 16, F). Interestingly, TLR $2^{-/-}$and TLR $4^{-/-}$NPCs exhibited increased apoptosis compared to WT NPCs, which was marked by an enhanced number of pyknotic nuclei (Figure 16, G). The significant increase in apoptosis could balance the increased proliferation in TLR2 $2^{--}$NPCs to explain the lack of difference in PDL compared to WT NPCs. As TLR4 ${ }^{-/-}$NPCs did not display higher proliferative rates, the significantly increased apoptosis rate may explain the observed reduction in PDL. 
A)
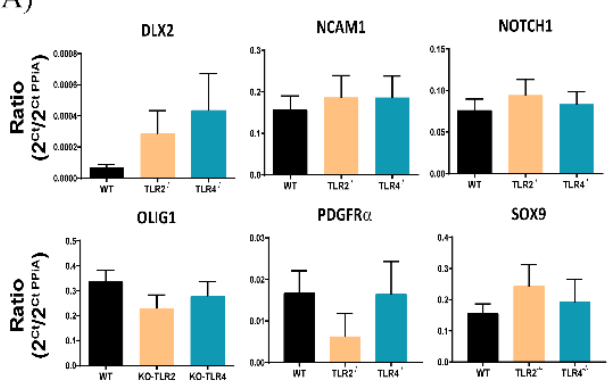

C)

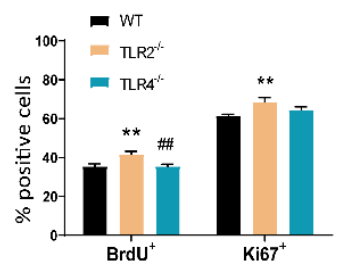

E)

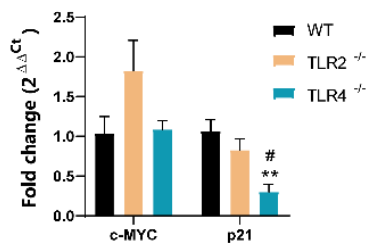

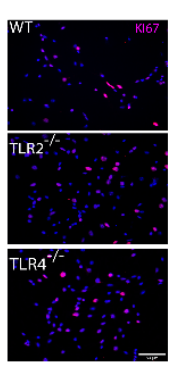

F)
B)

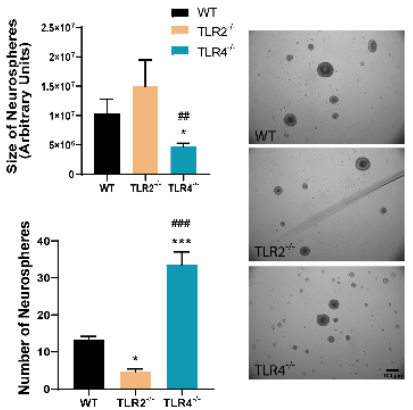

D)
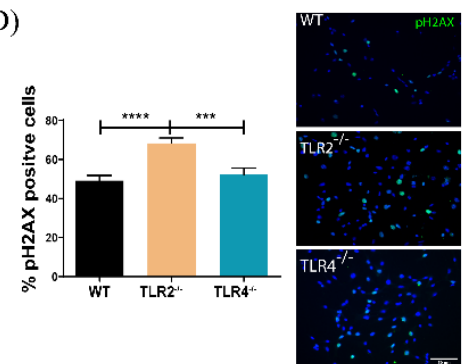

G)

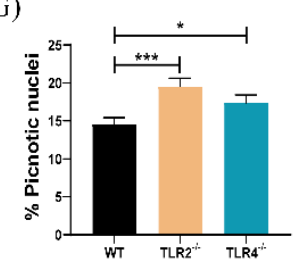

Figure 16. Involvement of TLR2 and TLR4 in the Self-renewal of NPCs.

A) Gene expression analysis in WT, TLR2 $2^{-/}$, and TLR4 $4^{-/}$NPCs. B) Quantification of size (upper graph) and number (lower graph) of neurospheres formed from WT, TLR2 ${ }^{-/}$, and TLR4 ${ }^{-/-}$NPCs 48 hours after disaggregation to single cells. * vs. WT; \# vs. TLR2 ${ }^{-/}$. Representative images of the indicated neurosphere-like cultures shown (right). C) (Left) Quantification of BrdU and Ki67-positive cells in WT, TLR2 ${ }^{-/}$, or TLR $^{-{ }^{--}}$NPCs represented as percentages of the total cells. * vs. WT; \# vs. TLR2 ${ }^{-/}$. (Right) Representative images of the immunofluorescence of Ki67 (red) with DAPI used for nuclei counterstaining (blue). D) (Left) Quantification of H2AX-positive cells in WT, $\mathrm{TLR}^{-/-}$, or TLR $4^{-/-}$NPCs represented as a percentage of total cells. * vs. WT; 
\# vs. TLR2 ${ }^{-/}$. (Right) Representative images of pH2AX (green) immunofluorescence with DAPI used for nuclei counterstaining (blue) in WT, TLR2 $^{-/-}$, or TLR4 ${ }^{-/-}$NPCs. E) Gene expression by qPCR of cMYC and p21 transcripts in WT, TLR2 ${ }^{-/-}$and TLR4 ${ }^{-/-}$NPCs. F) Population doubling level analysis in WT, TLR2 $2^{-/}$and TLR4 ${ }^{-/-}$NPCs expressed as the mean of three independent experiments. G) Quantification of pyknotic nuclei in WT, TLR2/- and TLR4 ${ }^{-/}$NPCs from DAPI nuclei staining (identified as smaller than normal with hyper condensate chromatin) represented as a percentage of the total cells. Data shown as mean \pm SEM ( $N=5$ per group). Results assessed for normality using the Shapiro-Wilk test and one-way ANOVA with Tukey post hoc test; *\#p<0,05, **\#\# p<0.01, *** \#\#\#p<0.001, **** p<0.0001.

Taken together, our data suggest that TLR4 maintains in vitro-expanded NPCs isolated from the postnatal mouse spinal cord in a proliferative and undifferentiated state, while TLR2 expression limits NPC proliferation and self-renewal.

\subsubsection{TLR2 and TLR4 in Differentially Contribution to the Formation of Mature Neurons and Glial Cells}

We finally sought to evaluate the contribution of TLR2 or TLR4 to glial or neuronal cell-fate determination by comparing WT, TLR2 ${ }^{-/}$, or TLR4 ${ }^{-/}$NPCs cultured under spontaneous differentiation conditions (day 7) with undifferentiated conditions (day 1). Experimental schemes (Figure 17, A and B, top) show the seeding of single cells onto Matrigel-coated plates for one day or seven days after growth factor withdrawal, with growth or differentiation media. We failed to observe any differences in neuronal ( $\beta 3$ Tubulin) (Figure 17, A, left panels, green) or 
astrocytic (GFAP) (Figure 17, A, right panels, red) differentiation of NPCs as a consequence of TLR2 or TLR4 loss after one day; however, we encountered significant differences in neuronal (Figure 17, B, left panels) but not astrocytic (Figure 17, B, right panels) differentiation as a consequence of TLR2 or TLR4 loss after seven days. TLR2 $2^{-/}$NPCs displayed a highly significant increase in neuronal differentiation compared to WT and $\mathrm{TLR}^{-{ }^{--}}$NPCs, while TLR $4^{-/-}$NPCs displayed significantly higher neuronal differentiation than WT NPCs. Interestingly, $\beta 3$ Tubulin-expressing neuron-like cells exhibited three different morphologies in all three genotypes (Figure 17, C). Type 1 cells are pyramidal-like neurons, with a prominent soma and numerous dendrites (a morphology compatible with mature neuron); Type 2 are immature-like neurons, which are small, with few neurites (a morphology compatible with undifferentiated neurons); and Type 3 cells were bipolar with very long axonal projections (morphology compatible with mature neurons). TLR2 ${ }^{-/-}$NPCs preferentially differentiated into Type 2 cells (immature neurons) and expressed elevated levels of DCX, a marker of very early NPCs (Figure 17, D, upper graph). Meanwhile, TLR $4^{-/-}$NPCs preferentially differentiated into Type 3 cells (mature neurons) but did not express higher levels of MAP2, a marker of mature neurons (Figure 17, D, lower panel), indicating a potential transitional stage of maturation. 
We next studied the neural cell fate identity of WT, TLR2/- or TLR4 ${ }^{-/}$NPCs by analyzing Neurogenin1 expression levels (254). Both self-renewing and spontaneously differentiated NPCs from TLR $4^{-/-}$NPCs expressed higher levels of Neurogenin 1 than WT and TLR2 ${ }^{-/-}$NPCs (Figure 17, E), indicating the priming of NPCs for neuronal maturation. Overall, TLR2 loss prevented neuronal maturation, while TLR4 loss enhanced neuronal maturation. We failed to find any differences in the percentage of astrocytic cells based on the positive reactivity of GFAP following analysis of WT, TLR2 ${ }^{-/-}$, or TLR $4^{-/-} \mathrm{NPCs}$ at one day or seven days after induced spontaneous differentiation; however, we discovered a significant increase in GFAP protein expression in $\mathrm{TLR}^{-/-}$NPCs (Figure 17, F), which has previously been associated with a reactive astrocytic phenotype (255). Analysis of the STAT3 protein, previously described to be involved in astrocytic reactivity (256), revealed a significant increase in $\mathrm{TLR}^{-/-}$NPCs compared with WT or TLR2 ${ }^{-/-}$NPCs (Figure 17, G), which could explain the reactive phenotypic profile found in the absence of TLR4. The analysis of oligodendrocyte differentiation in suitable growth-supporting medium found that WT, TLR2 ${ }^{-/-}$, and TLR4 ${ }^{-/-}$NPCs all expressed similar levels of Olig2, a transcription factor expressed in early to mature stage oligodendrocytes (257) (Figure 17, H, upper panels); however, after seven days of spontaneous differentiation, the absence of TLR2 significantly reduced the generation of Olig2-positive cells from NPCs (Figure 17, H, lower panels). 
Chapter 1: Results

We also found the significantly higher expression of SOX10, a transcription factor expressed in early OPCs (258), and the significantly lower expression of NG2, a factor expressed by mature OPCs (259), in the absence of TLR2 or TLR4. Overall, this data also suggests a critical role for TLR2 and TLR4 in oligodendrocyte maturation. 
A)
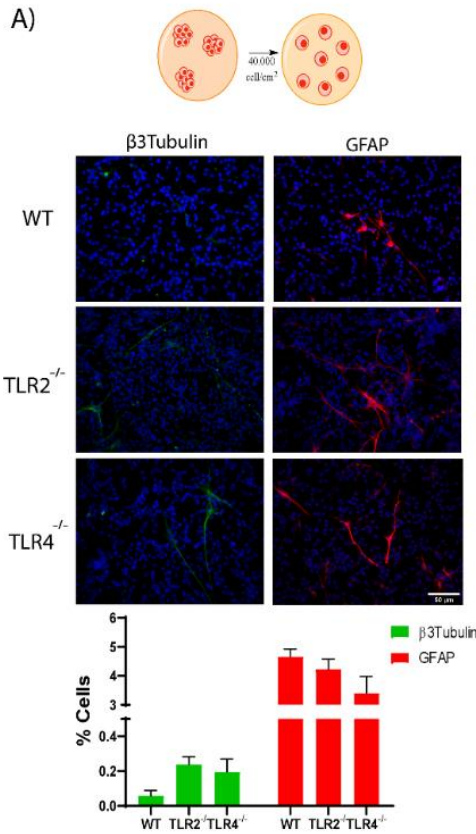

C)
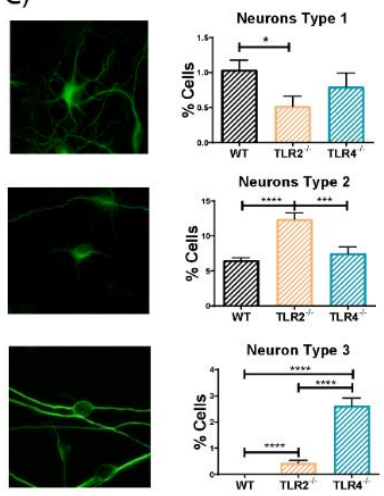

D)

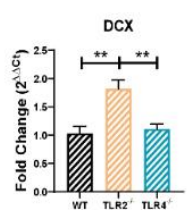

E)
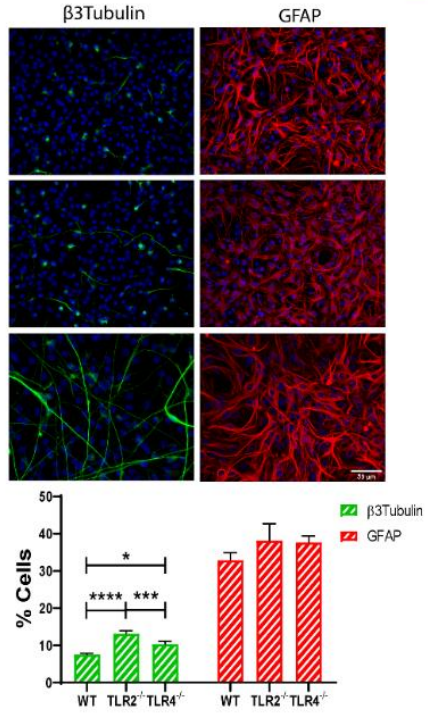

F)

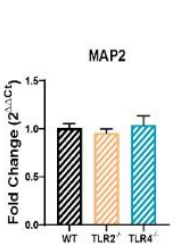

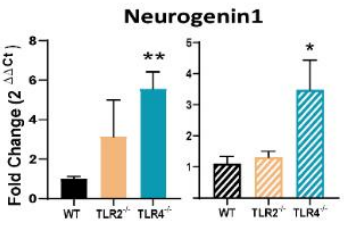

GFAP
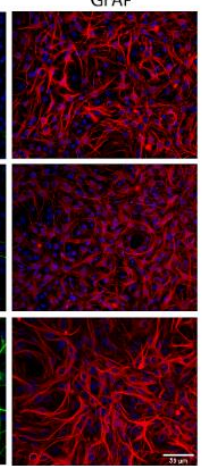

G)

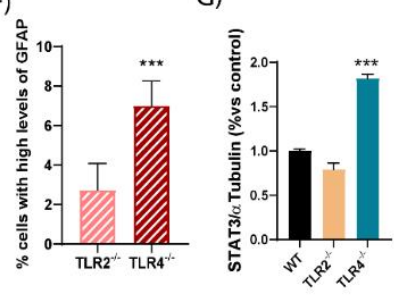

H)

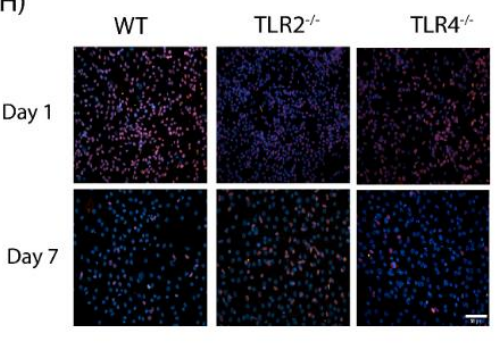

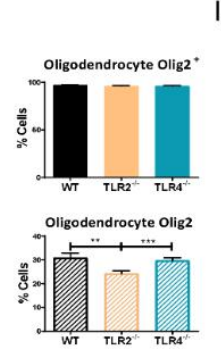

I)

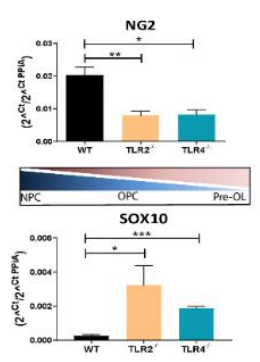


Figure 17. TLR2 and TLR4 Loss Influence the Spontaneous Differentiation of in vitro-expanded Spinal Cord NPCs. A, B) Representative immunofluorescence images of $\beta 3$ tubulin (neural marker; green) and GFAP (astrocytic marker, red) and the corresponding quantification data of the percentage of positive cells (lower panels) in NPCs grown in growth medium (A) or differentiation medium (B) as summarized in the diagrams (top images). DAPI used for nuclei counterstaining (blue). C) Morphological classification of the three distinct types of neurons identified from $\beta 3$ tubulin staining - type 1 (pyramidal-like cells; upper panel), Type 2 (rounded, with no cell expansions; central panel), and Type 3 (bipolar cells; lower panel). Quantification and comparative analysis of the percentage of the corresponding type of neurons shown for WT, TLR2 ${ }^{-/}$, and TLR $4^{-/-}$NPCs. D) Gene expression analysis of DCX (early neuronal marker, upper graph) and MAP2 (late neuronal marker, lower graph). E) Gene expression analysis of Neurogenin 1 in growth medium (left) or differentiation medium (right) in WT, TLR2 $^{-/-}$, and TLR4 ${ }^{-/-}$NPCs. F) Quantification and comparative analysis of GFAP protein expression levels in WT, TLR2 ${ }^{-/-}$, and TLR $4^{-/-} \mathrm{NPCs}$. G) Expression of STAT3 protein in WT, TLR2 $2^{-/}$, and TLR4 ${ }^{-/-}$NPCs $(\alpha$-tubulin as a loading control). H) (Left) Representative images of immunofluorescence staining of Olig2 (orange) in NPCs in growth medium (upper panels, day 1) and differentiation medium (lower panels, day 7). DAPI used for nuclei counterstaining. (Right) Quantitative analysis of Olig2-positive cells at one day (upper graph) and seven days (lower graph). I) Gene expression analysis for NG2 (upper graph) and SOX10 (lower graph). Data shown as mean \pm SEM $(\mathrm{N}=6$ per group for immunocytofluorescence images; $\mathrm{N}=4$ per group for qPCR experiment; $\mathrm{N}=3$ per group for WB assay). Results assessed for normality using the Shapiro-Wilk test and one-way ANOVA with Tukey post hoc test. $* \mathrm{p}<0.05$. $* * \mathrm{p}<0.01, * * * \mathrm{p}<0.001$. 


\subsection{Discussion}

Aside from their ability to respond to the innate immune system, Toll-like receptors such as TLR2 and TLR4 play fundamental roles in controlling NPC fate and maturation in the developing and adult mammalian brain (69); however, we understand little regarding their role in the spinal cord. In our exploration of TLR expression in the neonatal spinal cord, we discovered that TLR2 and TLR4 function to maintain neonatal spinal cord NPCs and influence cell fate determination through cell-autonomous functions. We propose that TLR2 promotes and TLR4 restricts neural maturation, at least in part by supporting the constitutively high expression of Neurogenin 1 .

During early postnatal stages, at a point when the mouse spinal cord remain incompletely differentiated, SOX2-expressing NPCs exist throughout the spinal cord (in the grey and white matter) lining the meninges and in the ependymal canal, where they co-express FoxJ1, representing the neurogenic niches (247). NPCs continuously express SOX2 until adulthood to maintain self-renewal capacity by regulating the expression of crucial genes; however, a shift of SOX2 location from the nucleus to the cytoplasm promotes their differentiation $(260,261)$. Hyperacetylation of SOX2 prompts translocation into the cytoplasm and then the differentiation of NPCs (262). We found that NPCs with nuclear SOX2 expression primarily located to the grey 
matter of the spinal cord and co-expressed the neuronal marker NeuN but lacked Ki67 expression (data not shown), indicating the existence of a transitional differentiation stage. Despite a significant reduction in the total number of SOX2-positive cells following the loss of TLR 2 or TLR4, the proportion of NPCs with cytoplasmic SOX2 remained unchanged, indicating a relevant and restrictive influence of both receptors at the undifferentiated stages when SOX2 retains its transcriptional activity. Since SOX2 positive precursors are actively dividing, we also expected a reduction in the acutely number of mitotic cells, positive for Ki67, however, neither TLR2 or TLR4 deletion significantly influenced over a global proliferating rate that deserves further investigation. Previous studies indicated that TLR4 deletion increases the proliferation of retinal precursors (79) while TLR2 deletion failed to modify mitotic rates in the hippocampus (65), therefore suggesting the existence of specific mechanisms for the TLR2 and TLR4-mediated regulation of NPCs in the postnatal mouse spinal cord.

To further evaluate the novel functions of TLR2 and 4 within the neurogenic niche of the spinal cord, we evaluated in vitro expanded neonatal spinal cord-derived NPCs as a model system. NPCs grown as 3D neurosphere cultures from postnatal or adult stages maintain spinal cord precursor markers such as Sox2 and FoxJ1, retain their self-renewal and multipotent capacity (252), , and take on a pinwheel-like cytoarchitectural 
structure, which mimics the in vivo organization of endogenous neurogenic niches (263). Our analysis of neurosphere demonstrated that TLR $4^{-/-}$but not TLR2 ${ }^{-/-}$NPCs reproduced in vivo findings, with a significant decrease in the percentage of nuclear Sox2-expressing cells. Furthermore, the reduction in the proliferative activity of TLR $4^{-/-}$NPCs agrees with a restricted self-renewal profile, validating the critical role of TLR4 in maintaining the undifferentiated stage of spinal cord precursors. $\mathrm{TLR}^{-/-}$NPCs formed larger primary neurospheres and displayed enhanced mitotic activity, but also exhibited significantly higher apoptosis rates, validating an enhanced self-renewal profile. The increased level of apoptosis could explain, in part, the reduced percentage of Sox2-positive NPCs found in the spinal cord in the absence of TLR2, which would not be balanced by the significant, although modest, increase in mitosis. In the adult hippocampus under physiological conditions, TLR2 deletion affects cell-fate decisions but not self-renewal, whereas TLR4 affects both proliferation and differentiation of NPCs (65).

Activated TLRs signaling has distinct consequences regarding neural precursor maturation - for instance, immortalized lines of human NPCs expressing TLR4 respond to LPS-mediated activation by significantly decreasing proliferation and survival, indicating that TLR4 contributes to self-renewal (80). This study also demonstrated that TLR4 activation supported neuronal and oligodendroglial differentiation, while 
TLR4 deletion led to the opposite effect (80), which agrees with our findings in mouse NPCs. In agreement with previous reports, we revealed the requirement for TLR2 and TLR4 expression for oligodendrocyte precursor maturation under physiological conditions $(53,80)$. NPCs lacking TLR2 or TLR4 become retained at an undifferentiated stage thanks to the elevated expression of Sox10 (associated with early oligodendrocyte commitment) and the reduced expression of NG2 (expressed at late stages during OPC maturation).

We understand little regarding the interplay between immune cells and NPCs and the precise cellular and molecular mechanisms involving TLRs activation. Complex cellautonomous and non-cell-autonomous mechanisms can operate concomitantly and through TLR-dependent signaling $(264,265)$ While immune-deficient mice exhibit impaired neurogenesis, and specific brain- $T$ helper cells can promote neurogenesis in the adult hippocampus (266) oligodendrocyte maturation and remyelination after damage in an inflammatory environment (i.e., after SCI) requires the expression of TLR4 (141). Wellorchestrated adaptive immune responses also support/induce oligodendrogenesis and neurogenesis. Activated microglia support oligodendrogenesis in response to IL-4, whereas IFN $\gamma$ activated microglia showed a bias towards neurogenesis (267). Neuron-enriched cultures promote oligodendrogenesis rather than astrogliogenesis, indicating that neurons, and not exclusively 
the immune cells within the neurogenic niche, participate in creating a permissive local microenvironment (268) Here, we show that TLR4 deletion in NPCs promotes neurogenesis during spontaneously induced differentiation,; however, whether cellcell interactions or the release of specific factors contribute to specific cell fate maturation remains unknown.

The Jak/Stat axis plays a pivotal role in NPCs by promoting astrocytic differentiation, reactivity (269), and survival (270) and neuronal differentiation (256). At early developmental stages, Jak/Stat pathway components drives the neurogenic phase, when astrocytic genes are still silent (256). Proneural proteins such as Neurogenin1, a bHLH protein, play an essential role in this process, as their deletion causes precocious astrocyte differentiation and limited neural cell fate(270). We found that the absence of TLR4 prompts an increase in both Neurogenin1 and Stat3 expression, which prompted neural differentiation and astrocytic activation. The STAT3-mediated neurogenic-to-astrogenic fate switch has been previously described in cultured NPCs(271) (reinforcing the idea of cellintrinsic programs (272)). 
Chapter 1: Discussion

Overall, we found a ligand- and microenvironmentindependent program regulating neonatal neurogenesis through TLR2 and 4 depending-signaling and Neurogenin 1 expression; thus, regulating TLRs signaling could represent an interesting means to induce cell plasticity and promote neural differentiation in the spinal cord. 


\title{
CHAPTER 2
}

\author{
ROLE OF TLR2 AND TLR4 IN SPINAL CORD \\ INJURY AFTER NEURAL PROGENITOR CELL \\ TRANSPLANTATION
}




\subsection{Introduction}

In 2007, Kigerl et al. reported roles for TLR2 and TLR4 in paw coordination and neuroinflammation after SCI in a mouse model (122). More recently, Church et al. reported that TLR4 deficiency led to marked decrease in oligodendrocyte numbers at chronic stages (141) which led to a lack of remyelination, impaired motor function, increased apoptosis, and the increased expression of pro-inflammatory proteins such as IL1 $\beta$ and TNF $\alpha$. (137). After SCI, loss of oligodendrocyte maturation (measured by the loss of NG2-positive cells) associated with a reduction in ferritin expression, has been directly linked to TLR4 activation $(273,274)$. In models of sciatic nerve (275) and spinal cord injury (276) the absence of TLR2 induces decreases in proinflammatory factor expression (e.g., TNF $\alpha$, IL1 $\beta$, and COX2), macrophage recruitment, and astrocyte activation. In addition, TLR2deficient animals display compromised microglial activity. Activation of IRF8 in microglia depended on p38-MAPK and NF $\mathrm{B}$ activation through the TLR2 pathway (275). The loss of thermal hyperalgesia (277) and allodynia following sciatic nerve and spinal cord injury (276) confirmed the involvement of TLR2 in neuropathic pain.

A transcriptomic analysis of the rat spinal cord genome, analyzing the differentially expressed transcripts after traumatic SCI, showed the relevance and dynamic progression of the TLR 
expression over time after injury (Figure 18; unpublished data from the Moreno laboratory). Figure 18 shows the bioinformatics analysis using three different databases GeneOntology (GO) http://geneontology.org/, REACTOME https://reactome.org/ and KEGG https://www.genome.jp/kegg/pathway.html , which shows significant differences related to TLR signaling between animals with lesions at different times (acute stage (1 week after injury; T1-T0), sub-acute stage ( 2 weeks after injury; T2-T0), chronic stages ( 4 or 8 weeks after injury; T4-T0 or T8-T0)). After SCI, both TLR-dependent (TLR2, 3, 4, and 9) and TRIF and oMYD88-dependent pathways become upregulated.

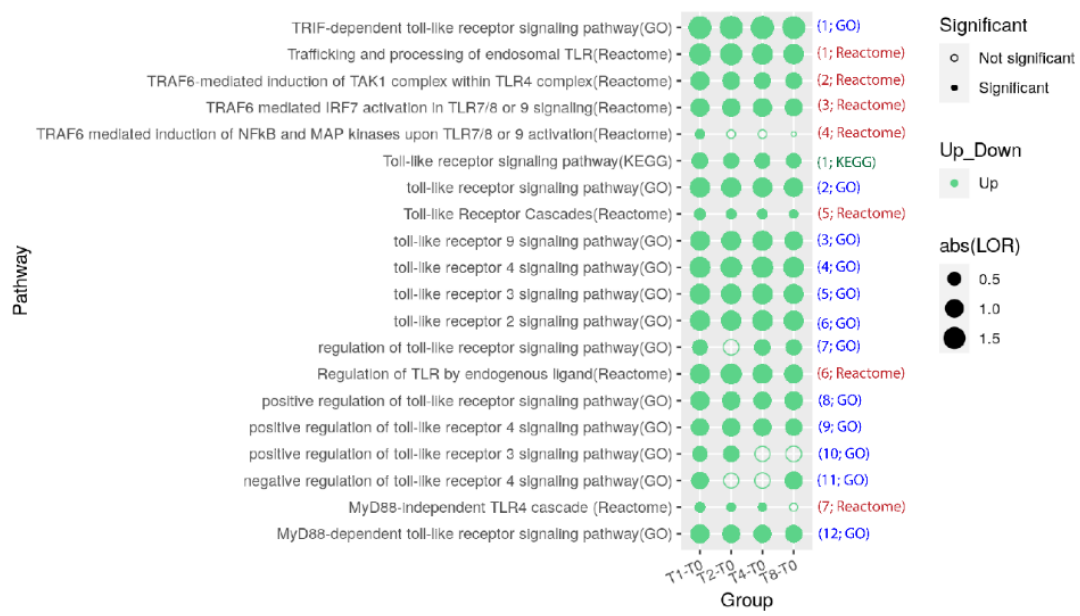

Figure 18. Dotplot of Pathways Related with the "TLR" GO Term. Agilent-014879 Whole Rat Genome Microarray 4x44K G4131F performed on rat spinal cord tissue samples obtained at various stages: T0: no injury; T1: acute, one week after injury; T2: subacute, two weeks after injury; T4: early chronic, four weeks after injury; T8: chronic, eight weeks after injury. 
Although the spinal cord is considered an immuneprivileged tissue (278), tolerance to transplantation after spinal cord injury is limited, with low survival rates due to overactivation of the immune response and consequent rejection and poor integration of the transplant (279), which necessitates the short-term use of immunosuppressive agents. A growing number of studies have demonstrated the involvement of TLRs in the enhancement of the immune response after allogeneic transplantation $(280,281)$. This correlates with the induction of TLRs by endogenous ligands produced by damage after transplantation. Activation of TLRs by exogenous ligands may prevent transplantation tolerance in a mechanism dependent on type I IFN production, which may be shared by pathogenic microorganisms (282). Despite the known pro-inflammatory role of TLRs signaling, target TLRs pathways can also lead an efficient immunosuppression strategy, and these mechanisms could be exploited in the future for novel therapeutic manipulations in transplanted patients.

FOXP3/expressing $\mathrm{CD}^{+}{ }^{+}$regulatory T cells (Tregs) play a critical role in maintaining immune tolerance following transplantation (283); however, their activity is deleterious in the absence of a balance between Tregs and effector or helper (Th) $\mathrm{T}$ cells to maintain inhibition of autoimmunity and reduce adaptive immune responses $(284,285)$. TLRs play a crucial role in transplant tolerance by modulating Tregs. TLR2 activation 


\section{Chapter 2: Introduction}

induces reprogramming of Tregs into Th cells by activating the NFkB-dependent pathway and inducing an adaptive immune response and rejection in xenotransplantation (286) Meanwhile, inhibition of TLR4 activation at the time of islets transplantation decreases proinflammatory signals and allows Treg generation in a diabetic model (287). While TLR2 deletion reduces innate immune signaling in the spinal cord, activation of TLR2 with Pam2CSK4 induces a shift in corpus callosum microglia from a pro-inflammatory iNOS ${ }^{+}$phenotype to a non-inflammatory/ prorepair Arg1+ phenotype in a multiple sclerosis model, inducing activation of a "tolerance" mechanism (288). Therefore, these studies reveal a possible new role for TLRs in the endogenous repair system after SCI.

Several studies have shown that NPCs or their secretome can modify the immune response by reducing the production of proinflammatory cytokines (TNF $\alpha$, IL-1 $\beta$, and IL-2), chemokines (MIP1 $\alpha$ and RANTES) (289,290), and iNOS (291). Transplantation of the human spinal cord cell line SPC-01 one week after SCI displays an immunomodulatory effect at 28 days post-injury through the canonical NFkB pathway (292). Transplantation of SPC-01 inhibited nuclear translocation of $\mathrm{NF \kappa B}$, leading to a decrease in the immune response and the production of apoptosis-related factors. This study demonstrated the robust immunomodulatory properties of SPC-01 cells based on the inhibition of an essential signaling pathway. NPCs 
transplanted into the injured spinal cord SCI survive, migrate, integrate, form functional synapses with endogenous neurons, and act as neuronal relays differentiating into all neural lineages (293).

This chapter evaluate the influence of TLR2 or TLR4 in the tolerability and therefore, efficacy of the NPC transplantation after SCI. First, we will evaluate and validate previous reported data (as described above), about the influence of TLR2 or TLR4 on spontaneous functional recovery from severe compression injury has been assayed in deficient mice for each of the receptors (Figure 19; experimental approach I). Second, efficacy of NPC, lacking TLR2 or TLR4, on functional neurological recovery upon transplantation (Figure 19; experimental approach II). Finally, the influence of the TLR2 or TLR4 activity from the hosted tissue, on NPC transplantation tolerance by studying the efficacy of naïve NPC transplantation into TLR2 or TLR4 deficient mice (Figure 19; experimental approach III). 
Chapter 2: Introduction

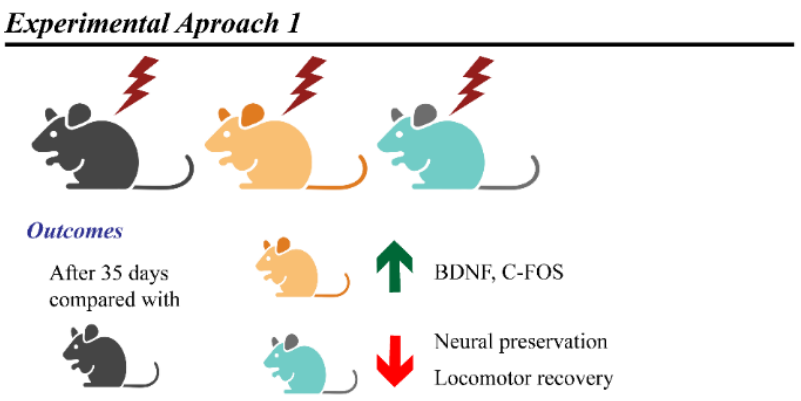

\section{Experimental Aproach 2}

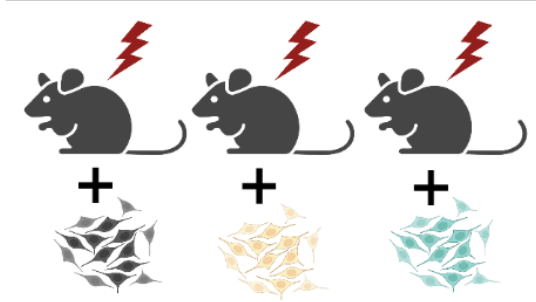

Outcomes

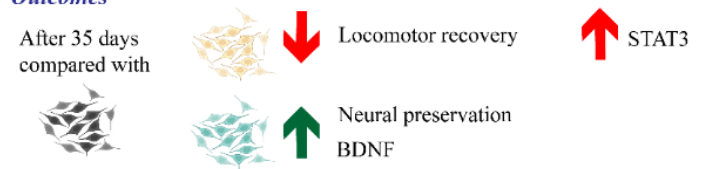

Experimental Aproach 3

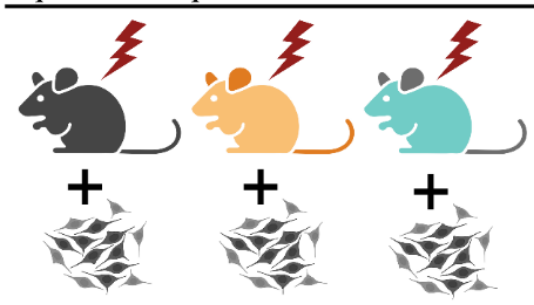

Outcomes

After 35 days, NPC transpnatation in WT, TLR2 $\%$ and TLR4 $\%$

1 Neural preservation

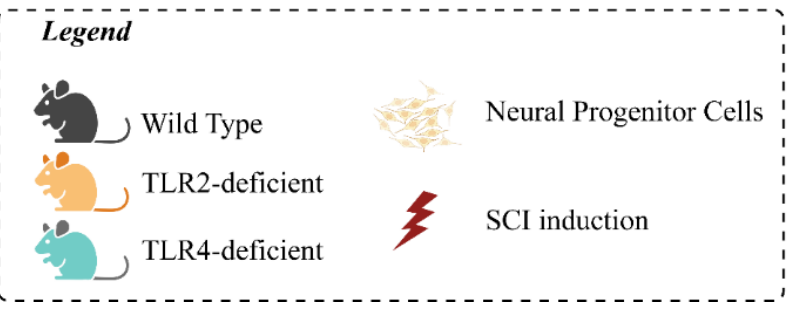

Figure 19. Chapter 2 Graphical Abstract 


\subsection{Results}

\subsubsection{Spontaneous recovery of hind limb function after SCI requires of TLR4}

We subjected adult female mice to spinal compression using a Bonn micro-forceps at the thoracic level T8 $(n=8)$ and evaluated the functional locomotor activity of the animals twice a week for 35 days after injury. First, we evaluated functional locomotion by using the Basso Mouse Scale (BMS) open-field locomotor scale test (210) (Figure 20, A). BMS assesses the recovery of locomotor activity through the mice movement recorded and compared with a normalized behaviour that includes the paw support, gait coordination and trunk stability. We first observed that the maximum score within all groups reached by the injured mice stayed in a range of 4-5 out of 9. This score is equivalent to recovering the ability to walk with some ability to bear weight but lacking coordination (Table 3), in accordance with previous reports for severe SCI $(141,206)$. We observed a slow-down in the recovery slope after the third week after SCI and then, all three genotypes reached a plateau indicating a stabilization of the injuries at the chronic stages characterized by the lack or minimal spontaneous regeneration (Figure 20, A; red dotted line). From day 11, we found that TLR $4^{-/-}$mice had deficits in hind limb movement (statistically significant from day 11, vs. WT; blue line); however, we did not find significant 
differences between WT and TLR2 ${ }^{-/-}$animals (Figure 20, A; orange line). By analyzing the percentage of animals that can lift their own weight with occasional or consistent stepping (with a BMS score equal to greater than 4 ), we discovered that $71.43 \%$ (WT), 50\% $\left(\mathrm{TLR}^{-{ }^{-}}\right)$, and $16 \%\left(\mathrm{TLR}^{-{ }^{-}}\right)$animals reached this threshold (Figure 20, B, solid blue). These data suggest the essential intrinsic TLR4 expression in spontaneous recovery of hind limb function. Nevertheless, it is important to note that TLR2 lacking expression animals, also showed a notably lower percentage of animals able to reach stepping associated scores (Figure 20, B).

A)

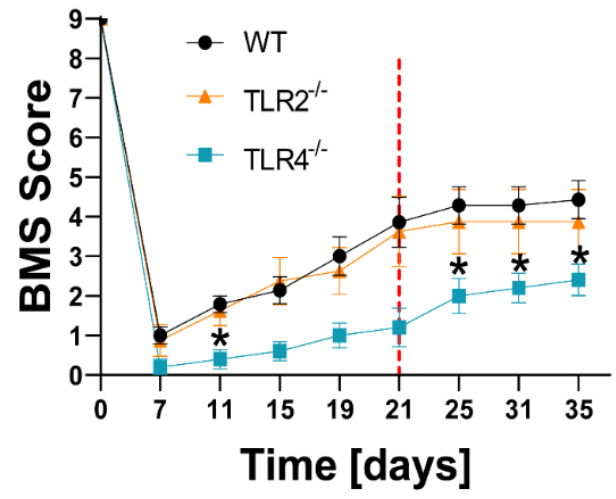

B)

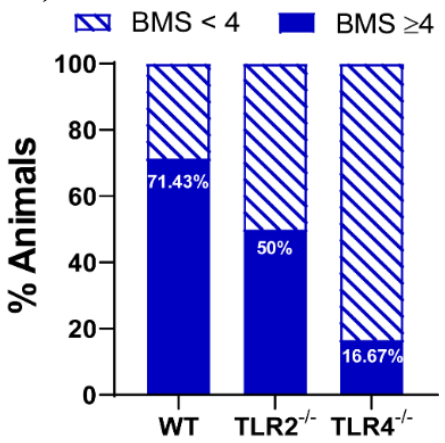

Figure 20. Locomotor recovery following spinal cord injury measured by BMS score. A) Time course locomotor evaluation by open-field BMS test from day 0 (healthy animal before surgery) until the 35 days post-SCI. Results assessed for normality using the Shapiro-Wilk test and analyzed using a twoway ANOVA with Bonferroni's post hoc test. Data shown as mean \pm SEM (n $=8$ animals per group). $* \mathrm{p}<0.05 \mathrm{WT}$ animals vs TLR4 ${ }^{-/}$animals. B) Bar 
graph showing the percentage of animals with a BMS score $<4$ ((striped) or $\geq$ 4 (full) at day 35 after injury.

The Ladder Beam test evaluates the capacity of the animals to walk through spared bars to quantify recovery of function following SCI, separating mice able to bear their own weight from those with consistent forelimb to hindlimb coordination (209). For this analysis, several parameters are individually evaluated such as no movement of the paws (-; scored as 0), miss paw placement (Miss; scored as 0,5), slipped step (Slip; scored as 1), skip paw placement (Skip; scored as 2), toe paw placement/partially plantar paw placement (Toe; scored as 3) and completely plantar paw placement (Plantar; scored as 4). Then, the maximum score reached by every group can be calculated by adding the individual score per each step and normalizing the sum by the total number of steps in one run, being $100 \%$ a score 4 for total step in the run.

The Ladder Beam test was analyzed at day 35 after SCI. In Figure 21, $\mathbf{A}$ is shown the percentage of animals that reached a maximum score. WT and TLR2 ${ }^{-/-}$animals have similar Ladder Beam scores (Figure 21, A), but TLR $4^{-/}$group showed a score close to $0 \%$. Furthermore, when we represented one by one the percentage of animals within each group able to perform every evaluated parameter during stepping, we observed that $83 \%$ of $\mathrm{TLR}^{-/-}$mice did not performed stepping, showing no movement 
at their paws when crossing the ladder (corresponding to 0 points, Table 2). In addition, some of the WT and TLR2 $2^{--}$animals, without significant differences between them, are able to do Toe placement, while the $\mathrm{TLR} 4^{-/}$animals are sub-divided into two groups, one group of animals grouped in "no movement" and other animals in "miss placement" group, indicating a significant limitation on the propriospinal and corticospinal tracts recovery (294-296) (Figure 21, B).

A)

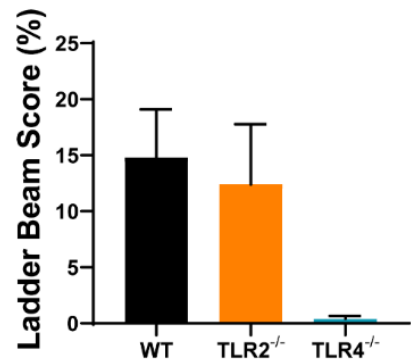

B)

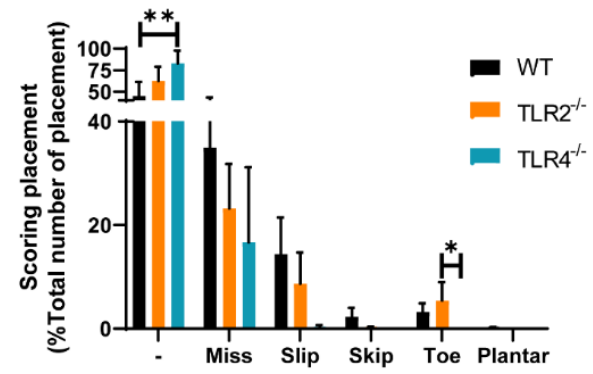

Figure 21. Evaluation of locomotor recovery following spinal cord injury by ladder beam test. A) Percentage of Maximum Score of the sum of the steps multiplied by the corresponding value shown in Table 3 divided by the total step score of each animal B) Bar graph shows the percentage of steps corresponding to each value indicated in Table 3. Results assessed for normality using the Shapiro-Wilk test, and one-way ANOVA with Tukey post hoc test used to analyze differences between conditions. Data shown as mean \pm SEM ( $\mathrm{n}=6$ animals per group). ${ }^{*} \mathrm{p}<0.05 ; * * \mathrm{p}<0.01$

We also analyzed locomotor function using the Catwalk Gait analysis at five weeks post-SCI (Figure 22). For the catwalk 
analysis, we analyzed animals with a BMS score higher or equal than 4 (71.43\% WT animals, 50\% TLR2 ${ }^{-/-}$animals, and $16.67 \%$ $\mathrm{TLR}^{-/-}$animals) as animals need to lift their weight perform in the Catwalk analysis (297), and to allow a comparison of potential differences in fine locomotion coordination and skilled walking.

We analyzed the paw's basic parameters, corresponding to their position at each stride (Figure 22, A). We did not find differences in stride length for the front or hind paws (Figure 22, B); however, we observed that TLR $4^{-/-}$animals have a shorter Base of Support (BOS), the average width $(\mathrm{cm})$ between the Front Paws of each animal when walking, when WT and TLR2 ${ }^{-/-}$ animals are compared, indicating a more limited locomotor coordination in this case. Furthermore, TLR2 ${ }^{-/-}$animals display a higher BOS in the hind paws than WT animals, indicating that it must exert more force to regain movement. In addition, we found that $\mathrm{TLR}^{-/-}$mice have a lower contact area of the hind paws than WT and TLR2 $^{-/}$but not in maximum contact in seconds compared to the WT group (Figure $22 \mathbf{C}, \mathbf{D}$ ), which indicates a maximum contact time within the hind paws during free and straight walking compared to the control group.

We also analyzed changes in paw index statistics related to the walking duration for both hind paws (Figure 22, E). Results show that WT front and hind paws are on the ground ("stand") (Figure 22, F, upper graph) for a longer time (in 
seconds) than TLR4 ${ }^{-/-}$animals; however, we failed to observe any significant differences in the time spent by paws in the air ("swing") (Figure 22, F, lower graph). Analyzing the percentage of duty cycle, calculated as the percentage of stand in a step cycle (swing + stand), we observe a similar pattern among groups found in the standing analysis (Figure 22, F).

Overall, the results of the functional analyses confirm a requirement for TLR4 in the spontaneous recovery of hind limb function reached by the WT animals. TLR2 deletion only exhibited a limited deficit in stepping coordination in comparison with the WT animals. 
A)

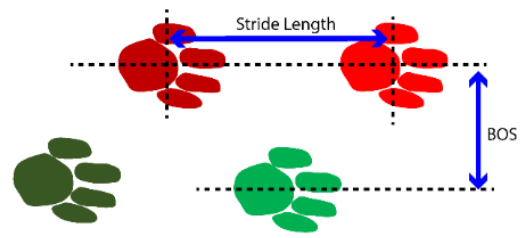

C)

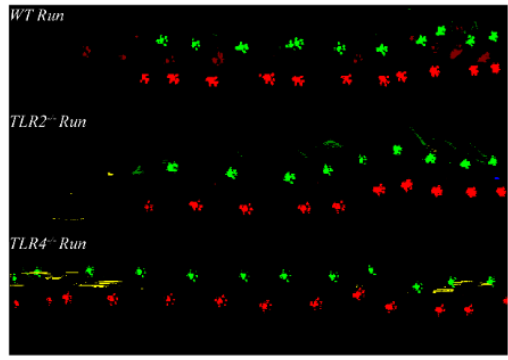

E)
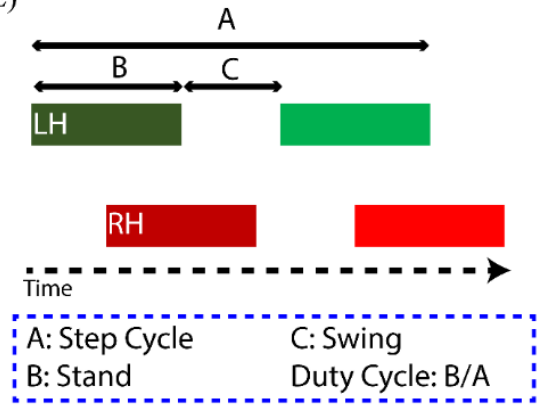

B)

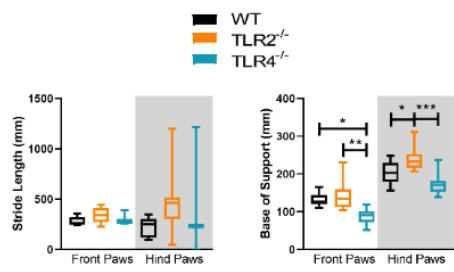

D)
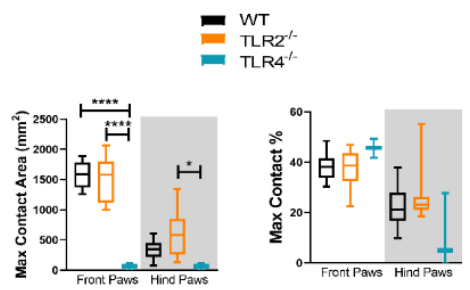

F)
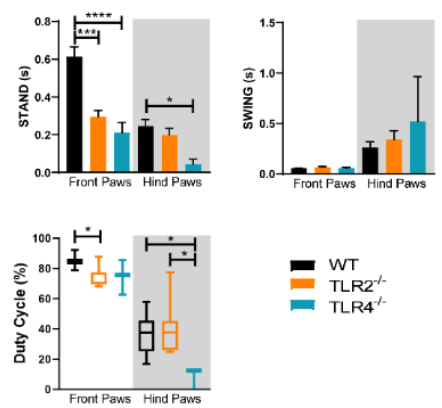

WT
TLR2
TLR4

Figure 22. Both, TLR2 and TLR4 deletion shows stepping coordination deficits by Catwalk gait analysis after SCI. A) Schematic representation showing stride length as the distance between successive placements of the same paw and BOS (base of support) as the average of width between either the front paws or the hind paws B) Box and violin representation of the quantification from stride length (left graph) in millimeter ( $\mathrm{mm}$ ) and base of support (right graph) in mm from front and hind paws. C) Representative runs from WT (upper), TLR2 ${ }^{-/-}$(middle), and TLR $4^{-/}$(lower) mice. Left paws 
represented in green, right paws in red, nose marker in blue, and tail marker in yellow. D) Box and violin representation of the quantification from max contact area (left graph) in $\mathrm{mm}^{2}$ and max contact percentage (right graph) from front and hind paws. E) Timing of right hind paw (RH) and left hind paw (LH) placement during CatWalk runs. The $\mathrm{X}$-axis shows time, and the two different bands indicate the contact durations of RH (red) and LH (green) with the ground. Step cycle is time in seconds between two consecutive initial contacts of the same paw (A), the stand is the duration of contact of a paw with the glass plate (B), the swing is the duration of no contact of a paw with the glass plate (C), and duty cycle is stand as a percentage of step cycle (B/A). F) Box and violin representation of time quantification from Stand and Swing (upper graphs) in seconds from front and hind paws and bar graph representing the percentage of Duty Cycle from front and hind paws (lower graph). Results assessed for normality using the Shapiro-Wilk test and one-way ANOVA with Tukey post hoc test used to analyze differences between conditions from Front paws or Hind paws. Data shown as mean \pm SEM ( $n=6$ animals per group). * $\mathrm{p}<0.05 ; * * \mathrm{p}<0.01 ; * * * \mathrm{p}<0.001$.

At day 35, 5 weeks after SCI, the animals were sacrificed and histological studies were performed. We analyzed paraffinembedded longitudinal spinal cord sections, including the epicenter of the injury (between T7 and T9), rostral (T6 to T7), and caudal (T9 to T10) segments close to the injury (Figure 23, A; Figure 24, A). We performed double immunostaining with $\beta$ III-tubulin (specific neurofilament marker (298)) (Figure 23, B, green) and GFAP (intermediate filament marker specifically found in astrocytes (299)) (Figure 24, B, red) to quantify the grade of neuronal fiber preservation and the extend of the scar formation (negative for GFAP, outlined in white), respectively. 
Data obtained from 4 animals per group for the $\beta$-III-tubulinpositive area revealed a significantly higher positive area in WT samples rostral to the lesion (Figure 23, C) than TLR2 ${ }^{-/-}$and $\mathrm{TLR}^{-/-}$samples. However, no differences were found in the caudal or lesion epicenter area (Figure 23, C), so the results suggest a more significant degeneration of neurons in the area rostral to the lesion in the TLR2 ${ }^{-/-}$and TLR $4^{-/-}$samples. On the other hand, results showed no significant in the size of the scar area, measured as the area negative for GFAP, delimiting the astrocytic barrier, among any of three groups (Figure 24, C), indicating that either TLR2 or TLR4 have influence on the scar formation, evaluated at the chronic stage. 
A)

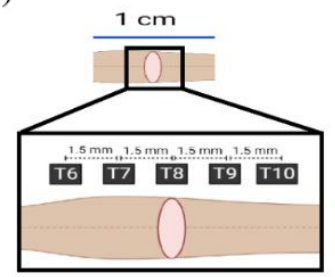

C)
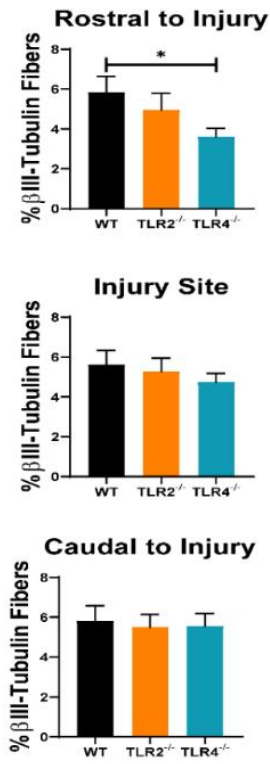

B)

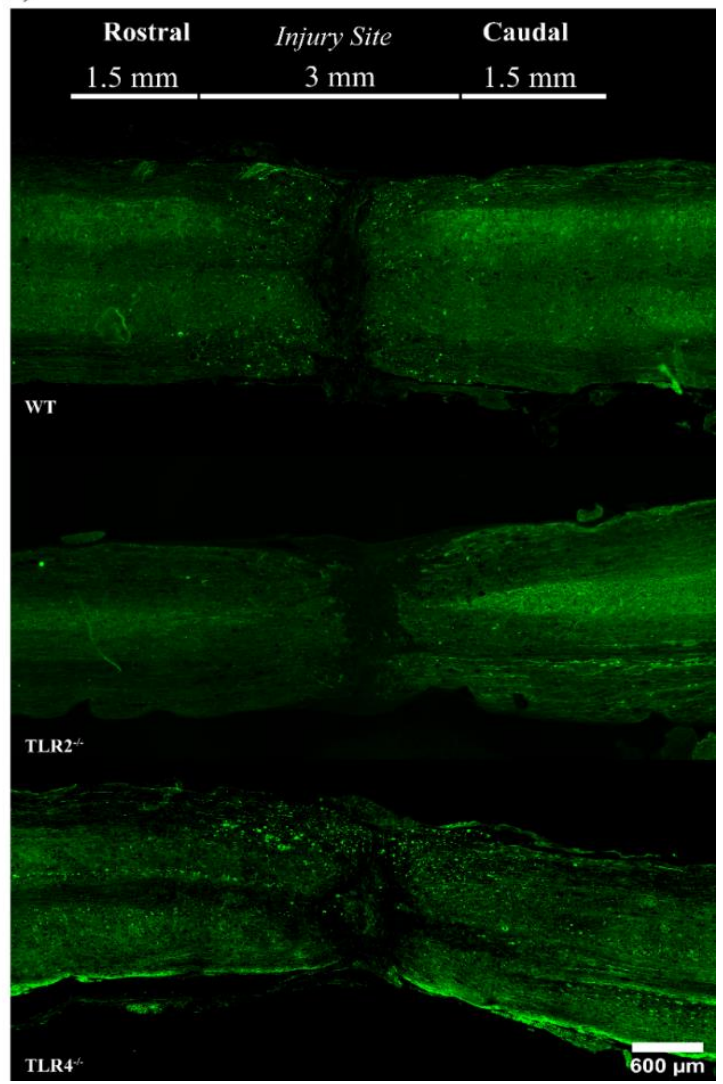

Figure 23. Histological analysis of neural fibres labelled with $\beta$ III-

Tubulin. A) Representative schematic of the spinal cord fragment chosen for analysis. For analysis the spinal cord was subdivided into $1.5 \mathrm{~mm}$ fragments equivalent to the distance between vertebrae in the mouse spinal cord. B) Representative immunofluorescence images of $\beta$-III-tubulin of longitudinal spinal cord sections including the $3 \mathrm{~mm}$ injured area and $1.5 \mathrm{~mm}$ of rostral and caudal area close to the lesion from WT (upper image), TLR2 $2^{-/-}$(middle image) and $\mathrm{TLR}^{-/}$(lower image) 5 weeks after SCI (scale bar $\left.600 \mu \mathrm{m}\right)$. C) Quantification of $\beta$-III-tubulin positive fibers in the rostral, injury and caudal area represented as a percentage of the total analyzed area. Results assessed for 
normality using the Shapiro-Wilk test and one-way ANOVA with Tukey post hoc test. Data are shown as mean \pm SEM ( $n=4$ animals per group). $* \mathrm{p}<0.05$.

A)

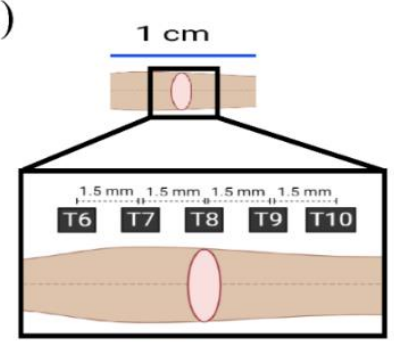

C)

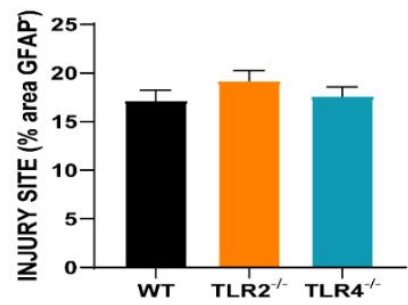

B)

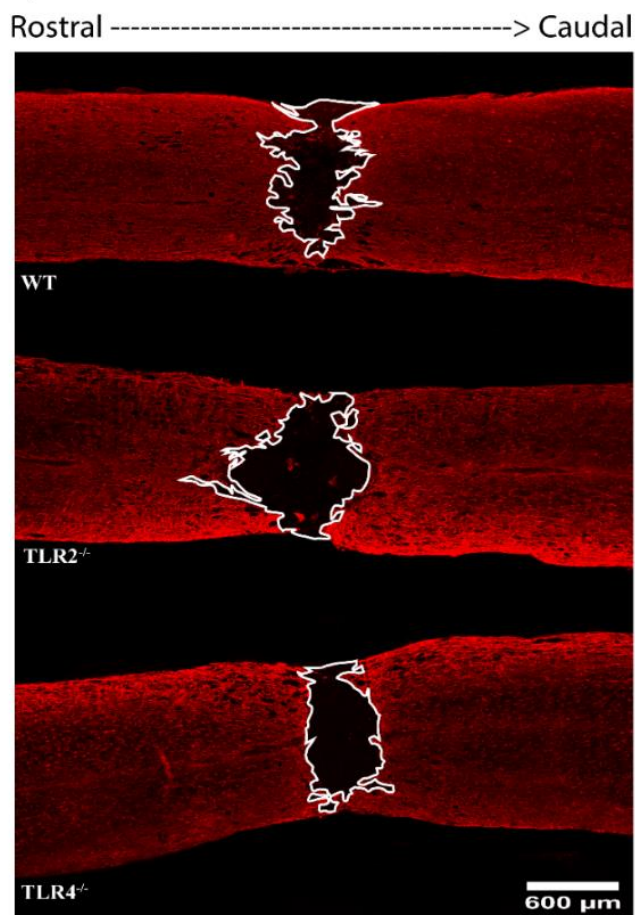

Figure 24. Histological analysis of fibrotic scar by delimitation of the area negative for GFAP staining. A) Representative schematic of the spinal cord fragment chosen for analysis. For analysis the spinal cord was subdivided into $1.5 \mathrm{~mm}$ fragments equivalent to the distance between vertebrae in the mouse spinal cord. B) Representative immunofluorescence images of GFAP of longitudinal spinal cord sections including the $3 \mathrm{~mm}$ injured area from WT (upper image), TLR2 ${ }^{-/-}$(middle image) and TLR4 ${ }^{-/-}$(lower image) 5 weeks after SCI (scale bar $600 \mu \mathrm{m})$. C) Quantification of GFAP negative area represented as a percentage of the total analyzed area $(3 \mathrm{~mm})$. Results assessed for normality using the Shapiro-Wilk test and one-way ANOVA with Tukey post hoc test. Data are shown as mean \pm SEM ( $n=4$ animals per group). 
We next evaluated proteins expression in spinal cord tissue lysates from rostral (rSC) and caudal (cSC) (Figure 25, A) segments to the tissue employed for histological analysis to evaluate:

1) The inflammatory milieu, based on the relative expression of ED1, a macrophage cell marker (300), Iba-1, microglia-macrophage cell marker (301), and iNOS, which over-expressed by pro-inflammatory stimulus(302).

2) Pro-regenerative signals, based on the relative expression analysis of the neurotrophin BDNF in the spinal cord (303), c-Fos, as a cell activation marker (304), and the cell death markers BCL2 (antiapoptotic) (305) and the pro-Caspase3 (proapoptotic)

3) The expression of critical factors in TLR-dependent signaling, such as STAT3 and ERK.

The evaluation of the inflammatory-related markers (ED1, Iba1, and iNOS) demonstrated a significant reduction in all three proteins in TLR $4^{-/-}$rostral samples (but not caudal) compared to WT or TLR2 ${ }^{-/}$samples (Figure 25, B). Previous studies found the upregulated expression of iNOS in caudal spinal cords segments of $\mathrm{TLR} 4^{-/}$mice with the worst functional outcomes (306), suggesting more significant secondary damage after the injury in the absence of TLR4 (307). 
We failed to encounter any differences in BDNF levels in the rostral spinal cord; however, TLR2 ${ }^{-/-}$caudal spinal cords display higher BDNF expression than WT and TLR4 ${ }^{-/}$caudal spinal cords. Interestingly, we also found an increase in cFOS expression in $\mathrm{TLR}^{-{ }^{-}}$animals in both rostral and caudal areas compared to WT animals and increased cFOS expression in $\mathrm{TLR}^{-/-}$caudal spinal cords compared to WT animals. A study reported increased cFOS expression as an indicator of active proliferation and differentiation in SCI lesion area (304), while a related study linked increased cFOS to neuronal damage (308). We did encounter lower expression of Caspase 3 in both rostral and caudal spinal cords in TLR4 ${ }^{-/}$animals than in WT and TLR2/- animals, indicating a decrease in cell apoptosis in the absence of TLR4.

Finally, we failed to observe any differences in total STAT3 and ERK protein expression in segments rostral to the injury; however, caudal spinal cord segments displayed higher expression of STAT3 in TLR2 ${ }^{-/-}$and TLR $4^{-/-}$animals compared to WT animals indicating a possible increase in astrocyte reactivity in these animals (309) (Figure 25, B). 
Chapter 2: Results

A)

WT-rSC TLR2 -rSC TLR4\%-rSC

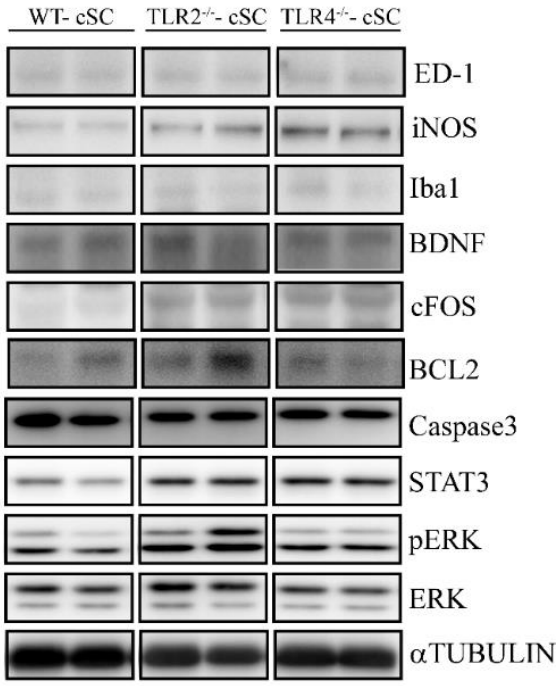

B)
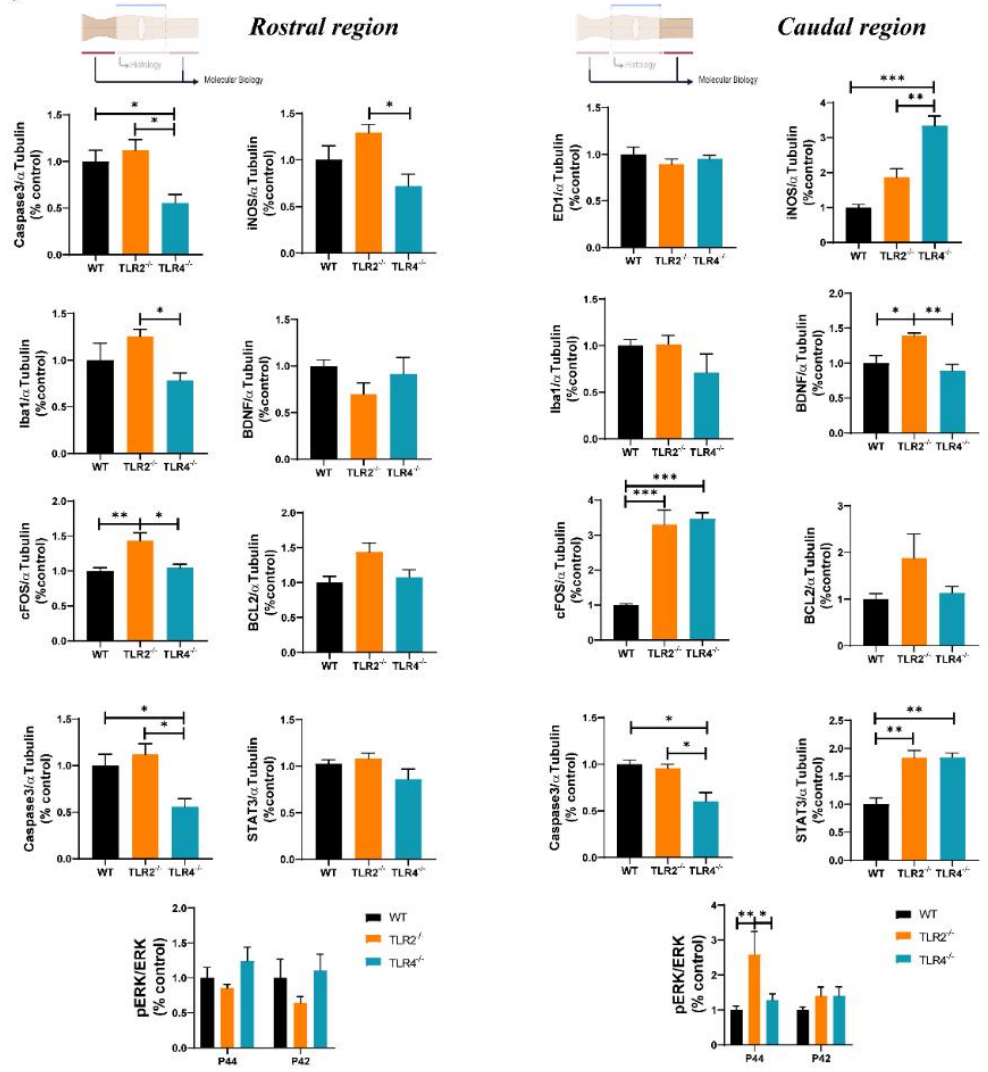
Figure 25. Western blotting analysis of the protein extracts from rostral (rSC) and caudal (cSC) region of spinal cords. A) Representative Western blots of rostral regions (left) and caudal regions (right) of spinals cord. B) Quantitative protein level normalized with $\alpha$ Tubulin as loading control in comparison with WT group. Results were assessed for normality using the Shapiro-Wilk test and one-way ANOVA with Tukey post hoc test was used to analyse differences between groups. Data are shown as mean \pm SEM $(n=4$ samples per group). $* \mathrm{p}<0.05 ; * * \mathrm{p}<0.01 ; * * * \mathrm{p}<0.01$.

\subsubsection{NPC, lacking TLR2 or TLR4, transplantation on functional neurological recovery after $S C I$}

NPC transplantation creates additional damage to the spinal cord caused by the inflammatory response of the cells in the tissue (310). This inflammatory response can lead to rejection of cell transplant and degeneration of the adjacent spinal cord tissue. We evaluated the relevance of TLR2 or TLR4 on NPC transplantation tolerance in SCI -in terms of cell survival and engraftment, and therefore, the influence on reduction of fibrotic scar, and preservation of host neural fibers.

We first induced NPCs from the three mice strains to express EGFP by using the pll3.1-EGFP lentiviral vector (see Material and Methods for detailed procedure. We evaluated whether the EGFP-NPC would influence naïve NPC survival, and we found that in all cases, the $85 \%$ of cells were efficiently transduced (Figure 26). 
A)

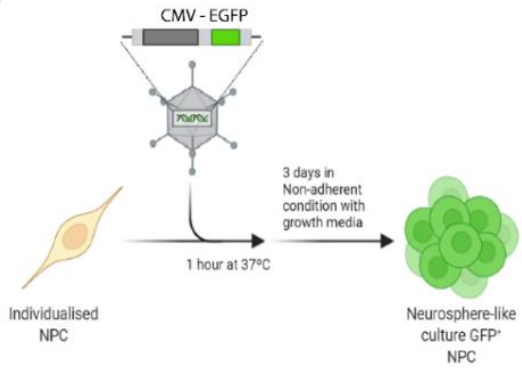

B)

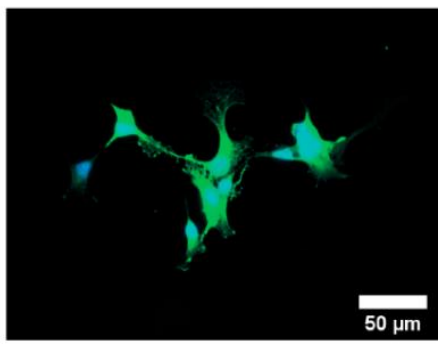

Figure 26. EGFP protein expression in NPC from neonatal mice. A) Schematic representation of infection of NPCs derived from postnatal mice with LV-EGFP. Individual NPCs incubated in growth medium in the presence of viral particles for 1 hour at 37 degrees. After a medium change to eliminate virus in the medium, the cells incubated for three days in the conditions explained in NPC culture until fluorescent protein was detected. B) GFP-NPC in adhesion condition three days after infection.

For in vivo cell transplantation, we injected 300,000 disaggregated eGFP-NPCs intramedullary $\sim 2 \mathrm{~mm}$ caudal to the injured area immediately after the SCI induced by mechanical compression (as previously shown and detailed described in the Material and Methods section) (Figure 27, A). Five weeks after transplantation, we found EGFP-NPCs integrated throughout the spinal cord thickness, especially in the dorsal region where they were transplanted. However, the cells concentrated at the injection site from the dorsal area to the middle of the spinal cord (210-280 mm depth) rostral to the injury. The cells showed a migratory capacity in the longitudinal axis, along the medulla, but not in within the transversal plane, from ventral to dorsal axis. As 
shown in the representative images from a horizontal section of the spinal cord (Figure 27, B), after immunostaining to detect GFP (green) and GFAP (red), in Figure 27, C, we mostly found eGFP-NPCs rostral to the lesion (Figure 27, c'), bordering the glial scar (delimited by the GFAP-positive signal, red), within the lesion (Figure 27, c'') with a few cells detected caudal to the injury (Figure 27, c'”').

A)

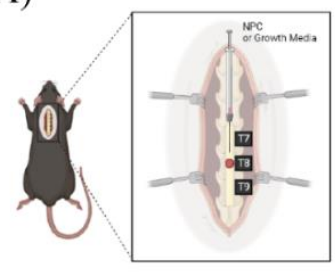

B)

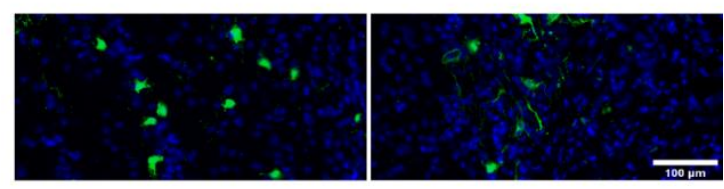

C)
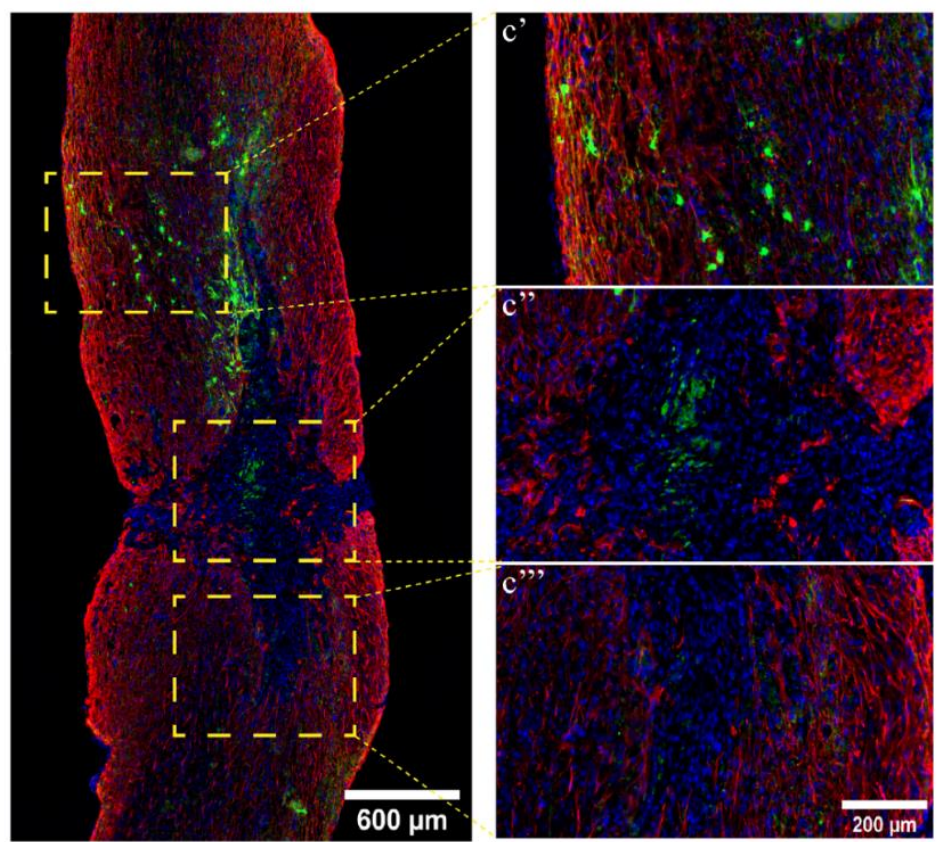
Figure 27. Detection and analysis of EGFP-NPC 35 days after transplantation. A) Schematic representation of NPC transplantation. After compression of the spinal cord at the T8 level, 300,000 GFP+ cells were transplanted rostral to the lesion, between $\mathrm{T} 7$ and $\mathrm{T} 8$. B) Immunohistochemistry of GFP-NPC transplanted (green) and DAPI (blue -for nuclei Counterstaining) in longitudinal spinal cord sections. C) Immunohistochemistry of GFP-NPC (green), GFAP (red), and DAPI (blue for nuclei Counterstaining) in longitudinal spinal cord sections. A magnified view of the indicated area with a yellow square for each staining showing GFPNPC transplanted locate rostral to the injury (c'), in the injury site (Area DAPI $^{+}-$GFAP $\left.^{-}\right)\left(c^{\prime \prime}\right)$ and fewer number caudal to the injury (c',').

The functional locomotion analysis based on BMS score data did not show significant differences among groups during the first month of analysis after transplantation. However, from day 21, animals transplanted with WT-NPCs or TLR2 ${ }^{--}$-NPCs reached a plateau of recovery, while WT animals with TLR $4^{-/}$ cells continue to improving. Moreover, the group of animals transplanted with the $\mathrm{TLR}^{-{ }^{--}}$-NPCs showed a significant improvement in locomotor recovery compared to the group of animals transplanted with TLR2 ${ }^{-/-}$-NPCs at day 35 (Figure 28). 


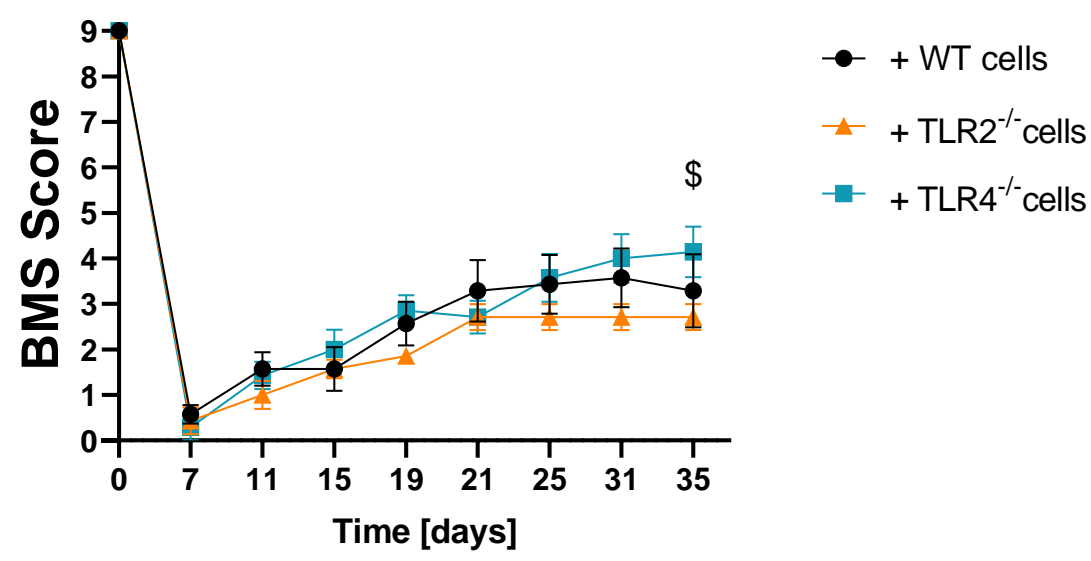

Figure 28. Locomotor recovery following spinal cord injury by BMS score from WT animals. Time course locomotor evaluation by open-field BMS over the 35 days post-SCI. Results assessed for normality using the ShapiroWilk test and analyzed using a two-way ANOVA with Bonferroni's post hoc test. Data shown as mean \pm SEM ( $n=8$ animals per group). $\$ p<0.05+$ TLR2।- cells vs +TLR4 ${ }^{-/}$cells.

The Ladder beam test did not reveal significant differences among all three groups when we analyzed the percentage of the maximum scores (Figure 29, A); we failed to encounter any significant differences between the paws when individually analyzing right and left (data not shown). However, a significant number of animals transplanted with WT- or TLR2I-NPCs showed no movement, compared with those transplanted with TLR $4^{-/}$-NPCs indicating that a smaller number of animals included in this group have footfall (Figure 29, B). Likewise, transplantation of $\mathrm{TLR}^{-/-}$-NPCs increases the percentage of animals with MISS scores (Figure 29, B). This group was the 
only one with animals able to support paw pad in the beam (TOE score) (Figure 29, B).

A)

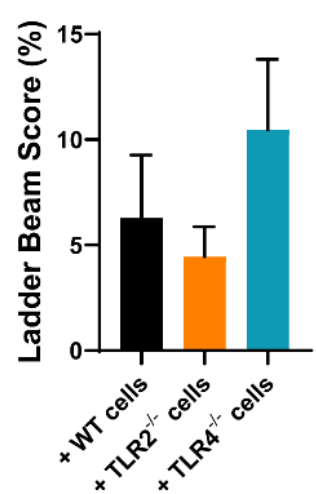

B)

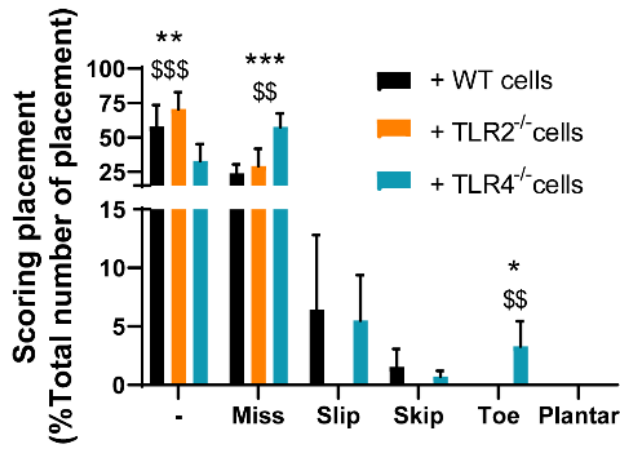

Figure 29. Evaluation of locomotor recovery following spinal cord injury by ladder beam test in WT animals. A) Percentage of Maximum Score of the sum of the steps multiplied by the corresponding value shown in Table 3 divided by the total step score of each animal. B) Bar graph shows the percentage of steps corresponding to each value indicated in Table 3. Results assessed for normality using the Shapiro-Wilk test, and one-way ANOVA with Tukey post hoc test used to analyze differences between conditions. Data shown as mean \pm SEM ( $\mathrm{n}=6$ animals per group). $*:+$ WT cells vs + TLR4 ${ }^{-1}$ cells and $\$:+$ TLR2 ${ }^{-/-}$cells vs + TLR2 $2^{-/}$cells. 1 significant symbol $\mathrm{p}<0.05,2$ significant symbol $\mathrm{p}<0.01$ and 3 significant symbol $\mathrm{p}<0.001$.

Next, we performed the footprint gain test analysis using the CatWalk device. Note that none of the animals transplanted with $\mathrm{TLR}^{-/-}$cells obtained sufficient score (BMS $\geq 4$ ) (Figure 28) without lifting their own weight, impeding the analysis in CatWalk test; therefore, we excluded this group from this 
analysis. First of all, we analyzed the paw's basic parameters, corresponding to their position at each stride (Figure 22, A), and we found that animals transplanted with TLR $4^{-/-}$-NPCs had smaller stride lengths in the front paws with no differences in the hind paws stride length. The group of animals transplanted with $\mathrm{TLR}^{-/-}$-NPCs had significantly shorter BOS distance in hind paws than animals transplanted with WT-NPCs (Figure 30, A), indicating worsts animal's walking stability (311).This finding confirms the lack of locomotion recovery of the animal by comparing the results with their corresponding uninjured control (Figure 49, Appendix). The maximum contact in seconds index, which indicates the maximum contact time recorded within the paws during free and straight walking, did not show differences among both groups at any of the paws (Figure 30, B). Although we found a significant difference when evaluating higher contact area (quantified in $\mathrm{mm}^{2}$ ), showing a significant reduction of the front paws in the group transplanted with TLR $4^{-/-}$cells (Figure 30, B), which would indicate that these animals have regained certain correct way of walking by supporting the minimum part of the paw pad (in comparison with the non-injured animals; Figure 49, Appendix). Finally, we analysed changes in the results from paw statistics related to walking duration for both paws (Stand, Swing and Duty Cycle) showing similar results in groups transplanted with TLR4 ${ }^{-/}$cells or WT cells (Figure 30, D). 
Therefore, we conclude from this set of experiments in a severe compression SCI model, that 1) the EGPF-NPC transplantation was not sufficient to rescue functional locomotion, 2) the cell engraftment of transplanted EGFP-NPC was not depending on the expression of TLR2 or 4 in the NPC, 3) transplantation of TLR4 deficient NPC confers better locomotor skills than the group of animals transplanted with WT or TLR2 deficient NPCs.

A)

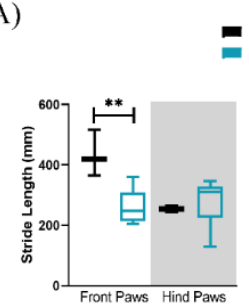

$$
\begin{aligned}
& \boldsymbol{m}+\mathrm{WT} \text { cells } \\
& \mathbf{W}+\mathrm{TLR}^{-1} \text { cells }
\end{aligned}
$$

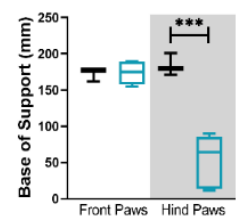

C)
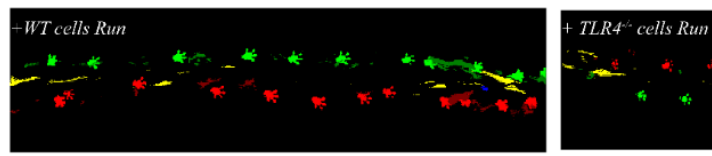

B)

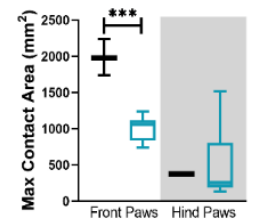

a + WT cells - TLR4 cells

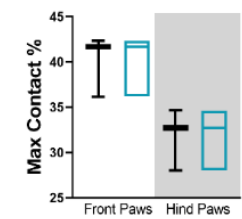

D) +WT cells
+ TLR4
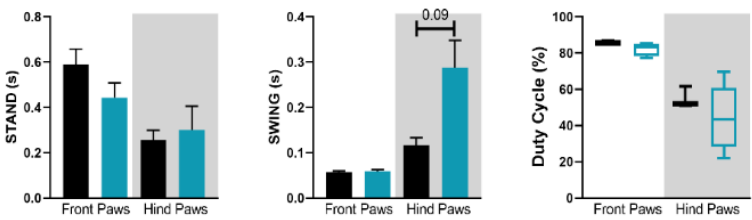

Figure 30. Catwalk Gait Analysis from WT animals after WT or TLR4 ${ }^{-/-}$ cell transplantation. A) Box and violin representation of the quantification from Stride Length (left graph) in millimetre ( $\mathrm{mm}$ ) and Base of support (right graph) in mm from Front and Hind paws. B) Box and violin representation of 
the quantification from Max Contact Area (left graph) in mm2 and Max contact percentage (right graph) from Front and Hind paws. C) Representative runs from WT animal + WT cells (left image) and WT animal + TLR4 ${ }^{-/-}$cells (right image) animals. Left paws are represent in green, right paws in red, nose marker in blue and tail marker in yellow. D) Bar graph representation of de the time quantification from Stand (on the left), Swing (on the middle) both in seconds from Front and Hind paws and box and violin represent percentage of Duty Cycle (on the right) from Front and Hind paws. Results were assessed for normality using the Shapiro-Wilk test and one-way ANOVA with Tukey post hoc test was used to analyse differences between conditions from Front paws or Hind paws. Data are shown as mean $\pm \operatorname{SEM}(\mathrm{n}=6$ animals per group). ** $\mathrm{p}$ $<0.01 ; * * * \mathrm{p}<0.001$.

As previously shown in Figures 23 and 24, we performed histological analysis at the epicenter of the injury in all the experimental groups. We analyzed longitudinal spinal cord sections by double immunostaining with $\beta$-III-tubulin (representative images shown in Figure 31, B) and the negative area delimited by GFAP (representative images shown in Figure $32, \mathbf{B})$ to evaluate the grade of neuronal fiber preservation and the extension of the scar area, respectively. We quantified the $\beta$-IIItubulin (green)-positive area at the epicenter of the injury, including $3 \mathrm{~mm}$ length, $1.5 \mathrm{~mm}$ rostral, and $1.5 \mathrm{~mm}$ caudal to the epicenter as indicated in the images (Figure 31, A). Results revealed a higher but not significant area positive for $\beta$-III-tubulin rostral and caudal to the lesion in WT animals transplanted withTLR4 $^{-/-}$-NPCs (Figure 31, C) compared to WT animals transplanted with WT or TLR2 ${ }^{-/-}$-NPCs. Interestingly, when we 
evaluated the size of the inhibitory scar by measuring the area delimited by the GFAP-positive border and then negative for GFAP staining, we found that the animals transplanted with $\mathrm{TLR}^{-/-}$cells had a significantly higher scar area (Figure 32, C).

A)

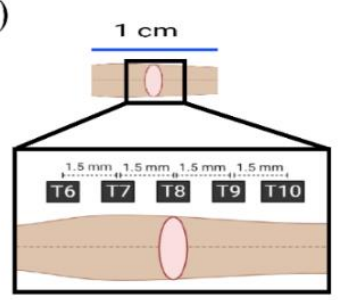

C)
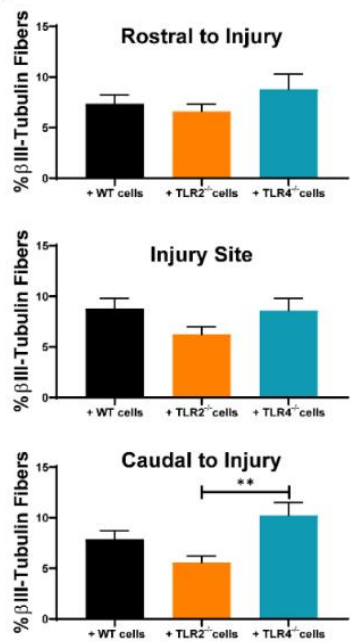

B)

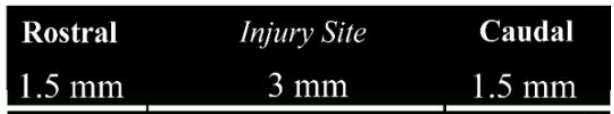

Figure 31. Histological analysis of neural fibres labelled with $\beta$ III-Tubulin from WT animals with NPC transplanted A) Representative schematic of the spinal cord fragment chosen for analysis. For analysis the spinal cord was subdivided into $1.5 \mathrm{~mm}$ fragments equivalent to the distance between vertebrae in the mouse spinal cord. B) Representative immunofluorescence images of $\beta$ III-tubulin of longitudinal spinal cord sections including the $3 \mathrm{~mm}$ injured area 
and $1.5 \mathrm{~mm}$ of rostral and caudal area close to the lesion from WT animal + WT cells (upper image), WT animal + TLR2 ${ }^{-/}$cells (middle image) and WT animal + TLR4 ${ }^{-/}$cells (lower image) 5 weeks after SCI (scale bar $\left.600 \mu \mathrm{m}\right)$. C) Quantification of $\beta$-III-tubulin positive fibres in the rostral, injury and caudal area represented as a percentage of the total analysed area. Results assessed for normality using the Shapiro-Wilk test and one-way ANOVA with Tukey post hoc test. Data are shown as mean \pm SEM ( $n=4$ animals per group). $* * \mathrm{p}<0.01$.

A)

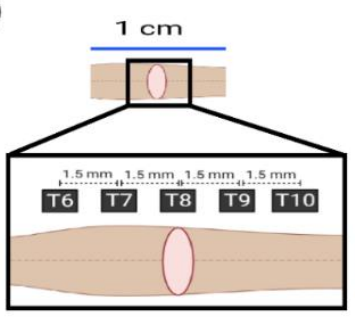

C)

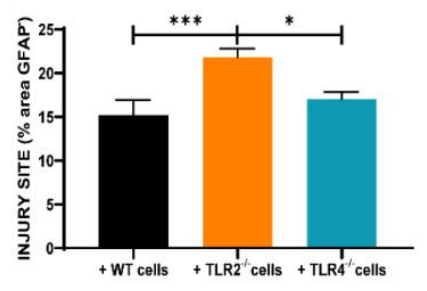

B)

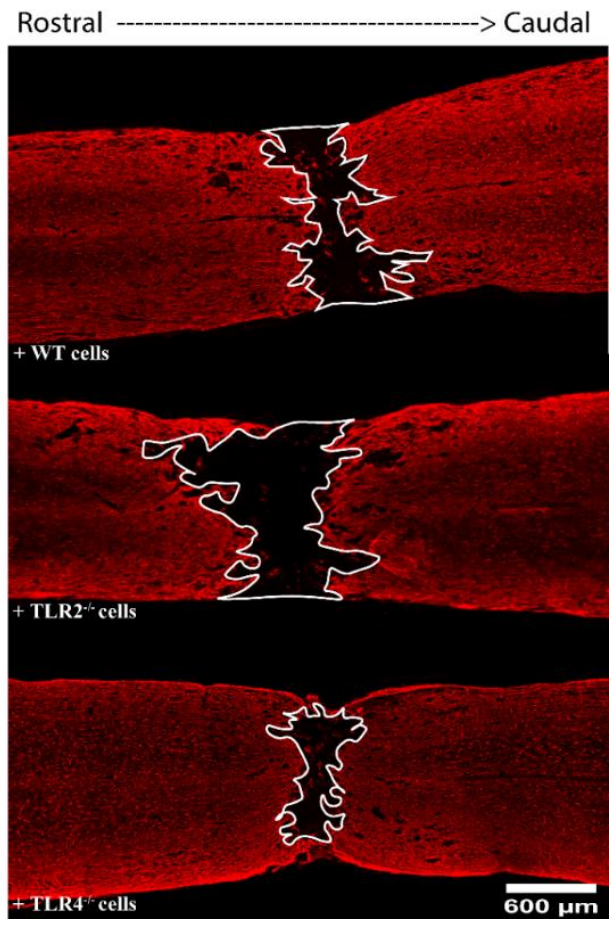

Figure 32. Histological analysis of fibrotic scar by delimitation of the area negative for GFAP staining from WT animals with NPC transplanted. A) Representative schematic of the spinal cord fragment chosen for analysis. For analysis the spinal cord was subdivided into $1.5 \mathrm{~mm}$ fragments equivalent to the distance between vertebrae in the mouse spinal cord. B) Representative immunofluorescence images of GFAP of longitudinal spinal cord sections 
including the $3 \mathrm{~mm}$ injured area from WT animal + WT cells (upper image), WT animal + TLR2 ${ }^{-/-}$cells (middle image) and WT animal + TLR4 ${ }^{-/-}$cells (lower image) 5 weeks after SCI (scale bar $600 \mu \mathrm{m}$ ). C) Quantification of GFAP negative area represented as a percentage of the total analyzed area (3 $\mathrm{mm}$ ). Results assessed for normality using the Shapiro-Wilk test and one-way ANOVA with Tukey post hoc test. Data are shown as mean \pm SEM ( $n=4$ animals per group). Transplantation of NPC lacking TLR4 increased inflammatory-related markers such as ED1, rostral and caudal segments, iba1 and iNOS, at the rostral segment (Figure 33, B). Nevertheless, this group of animals transplanted with TLR4 ${ }^{-/-}$ NPCs showed a significantly higher expression of BDNF, which could be associated to the better functional responses, but not significant differences were found in cFos levels (Figure 33, B). 
Chapter 2: Results

A)
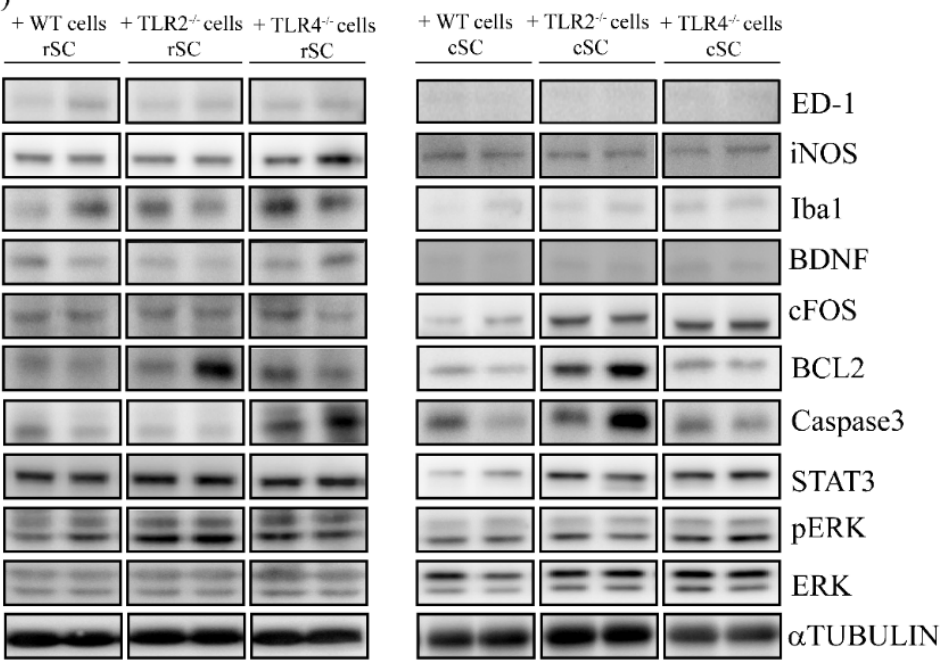

B)
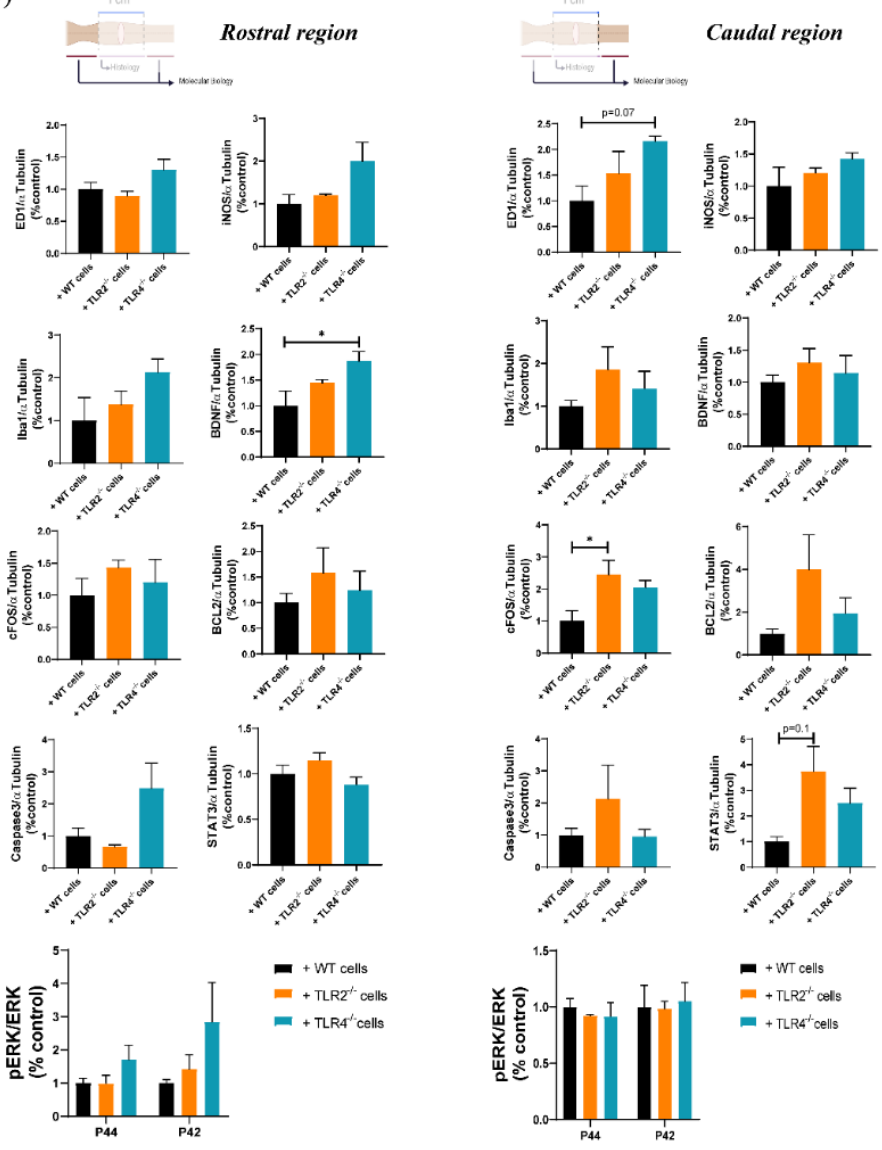
Figure 33. Western blotting analysis of the protein extracts from rostral (rSC) and caudal (cSC) region of spinal cords from WT animals with NPC transplanted. A) Representative Western blots of rostral regions (left) and caudal regions (right) of spinals cord. B) Quantitative protein level normalized with $\alpha$ Tubulin as loading control in comparison with WT group. Results were assessed for normality using the Shapiro-Wilk test and one-way ANOVA with Tukey post hoc test was used to analyze differences between groups. Data are shown as mean \pm SEM ( $n=4$ samples per group). $* \mathrm{p}<0.05$.

\subsubsection{WT-NPCs partially rescue specific impaired locomotor skills exhausted in TLR4 deficient mice after severe spinal cord compression}

To evaluate the influence of the TLR2 or TLR4 receptors on the NPC regenerative capabilities after SCI transplantation, we transplanted WT-NPCs into mice lacking TLR2 or TLR4 (see for a detailed procedure in Material and Methods).

We first evaluated all animals using the BMS score for functional locomotion in an open field since day seven after injury and transplantation. BMS (Figure 34) and Ladder beam test (Figure 35) data did not show significant differences among all pairs of comparisons: WT-NPC transplantation into WT animals, $\mathrm{TLR}^{-/-}$, or TLR $4^{-/-}$animals. However, we observed that TLR $4^{-/-}$ animals with transplanted WT-NPCs scored higher than TLR4 ${ }^{-/-}$ animals without transplantation (Figure 35, A). 

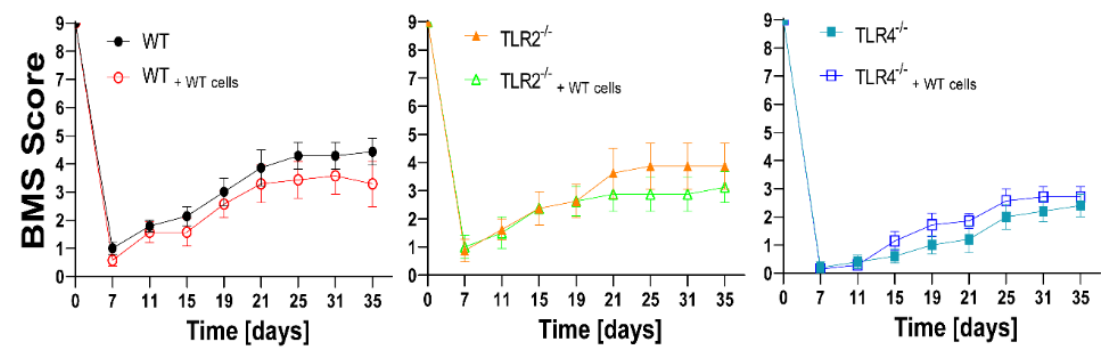

Figure 34. Locomotor recovery following spinal cord injury measured by BMS score in WT and TLR2 ${ }^{-/}$or TLR4 ${ }^{-/-}$animals with WT-NPCs transplantation. Time course locomotor evaluation by open-field BMS test from day 0 (healthy animal before surgery) until the 35 days post-SCI from WT animals (black), WT animals with WT cell transplantation (red), TLR2 $2^{-/-}$ animals (orange), TLR2 ${ }^{-/}$animals with WT cell transplantation (green), TLR4I- animals (blue) and TLR4 ${ }^{-/}$animals with WT cell transplantation (dark blue). Results were assessed for normality using the Shapiro-Wilk test and analysed using a two-way ANOVA with Bonferroni's post hoc test. Data are shown as mean \pm SEM ( $n=6$ animals per group).

A)

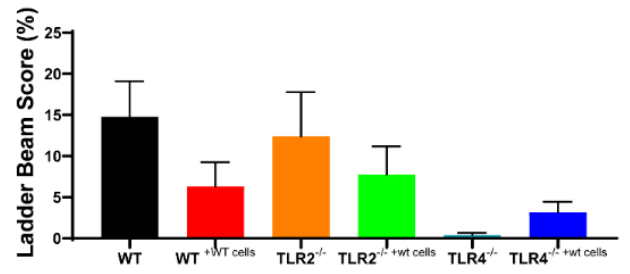

B)
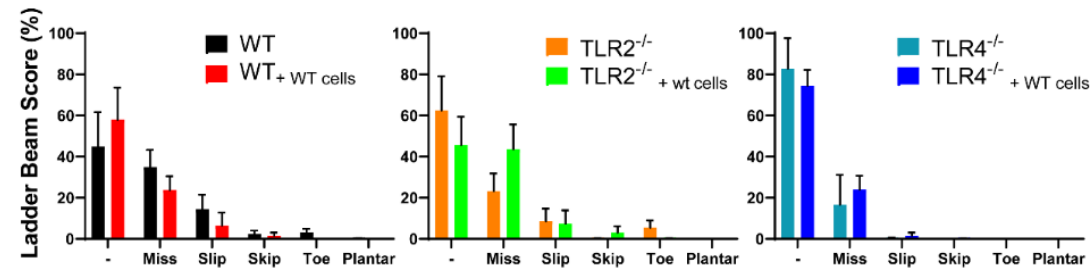
Figure 35. Evaluation of locomotor recovery following spinal cord injury by ladder beam test in WT and TLR2 ${ }^{-/-}$or TLR4 ${ }^{-/}$animals with WT-NPCs transplantation. A) Percentage of Maximum Score of the sum of the steps multiplied by the corresponding value shown in Table 3 divided by the total step score of each animal. B) Bar graph shows the percentage of steps corresponding to each value indicated in Table 3. Results assessed for normality using the Shapiro-Wilk test, and one-way ANOVA with Tukey post hoc test used to analyze differences between conditions. Data shown as mean \pm SEM ( $n=6$ animals per group).

CatWalk gait analysis -for a skilled locomotion analysisshowed that TLR2 $^{-/}$group transplanted with WT-NPC have significantly less BOS than TLR2 ${ }^{-/-}$animals (Figure 36, A), indicating that animals do not gain walking stability with cell transplantation. We also found that $\mathrm{TLR}^{-{ }^{--}}$mice transplanted with WT-NPCs have more extensive contact areas than nontransplanted cells. In this case, we observed that the TLR $4^{-/}$ animals had lower contact compared to their uninjured control (Figure 49, Appendix) and that the transplanted animals increased this contact approaching the levels of the injured WT and uninjured TLR $4^{-/-}$animals, so the increased contact area indicates that the animals are able to better support their weight with cell transplantation. WT-NPC transplantation also recovers when the front and hind paws "stand" on the ground in TLR4 $4^{-/}$ animals (Figure36, D). This leads to an increase in the Duty Cycle and makes TLR4 ${ }^{-/-}$animals with WT-NPC transplantation have a similar step to WT and TLR2 ${ }^{-/-}$animals (Figure 36, E). 
Chapter 2: Results

A)
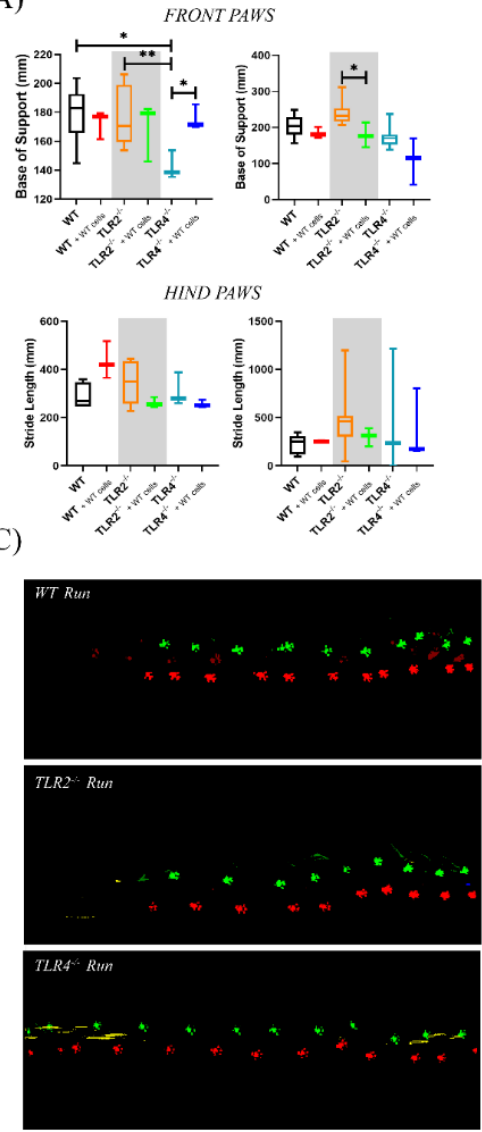

B)
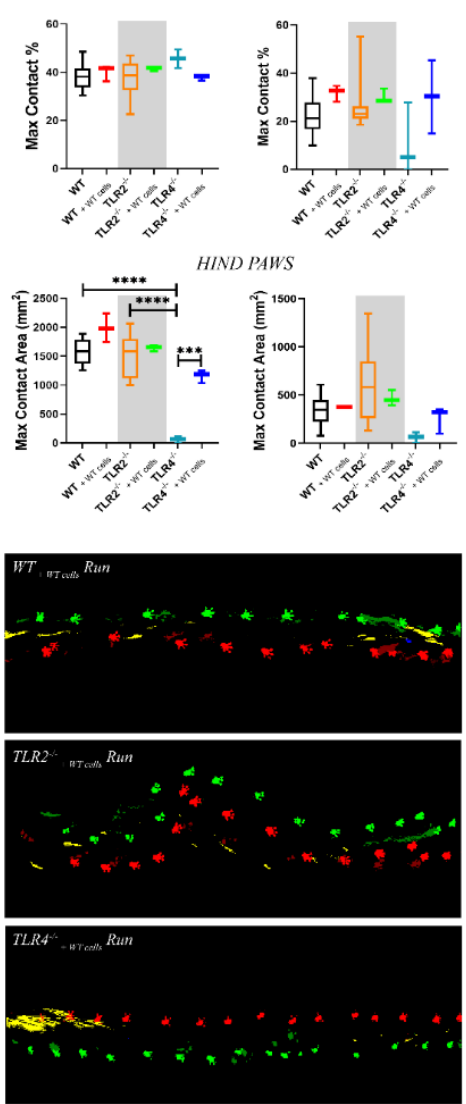

D)
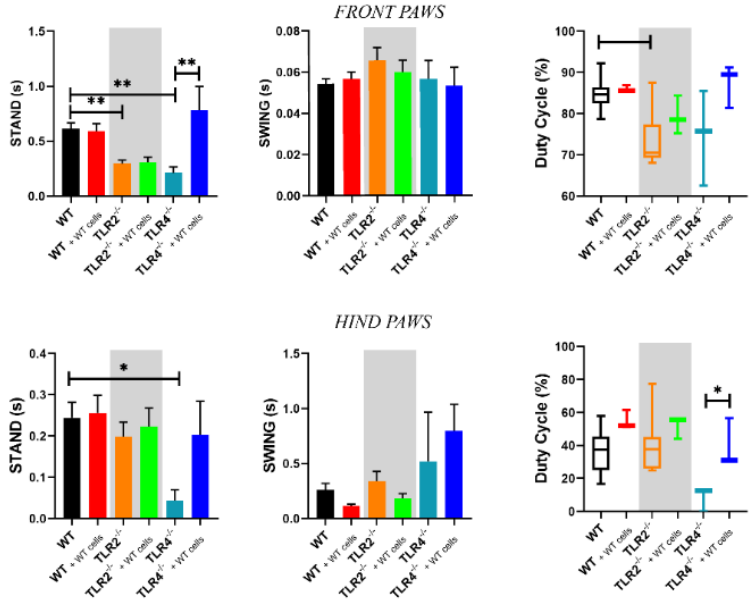
Figure 36. Catwalk Gait Analysis from WT and TLR2 ${ }^{-/-}$or TLR4 ${ }^{-/-}$ animals with WT-NPCs transplantation. A) Box and violin representation of the quantification from Stride Length (left graph) in millimetre (mm) and Base of support (right graph) in mm from Front (upper graphs) and Hind (lower graphs) paws. B) Box and violin representation of the quantification from Max Contact Area (left graph) in $\mathrm{mm}^{2}$ and Max contact percentage (right graph) from Front (upper graphs) and Hind (lower graphs) paws. C) Representative runs from WT, $\mathrm{TLR}^{-/-}$and TLR4 ${ }^{-/-}$animals (left) and animal with WT cell transplantation (right). Left paws are represent in green, right paws in red, nose marker in blue and tail marker in yellow. D) Bar graph representation of de the time quantification from Stand (left graphs) and Swing (middle graphs) both in seconds) paws and Box and violin represent percentage of Duty Cycle in percentage (right graphs) from Front (upper graphs) and Hind (lower graphs). Results were assessed for normality using the Shapiro-Wilk test and one-way ANOVA with Tukey post hoc test was used to analyse differences between conditions from Front paws or Hind paws. Data are shown as mean \pm SEM ( $\mathrm{n}=6$ animals per group). $* \mathrm{p}<0.05 ; * * \mathrm{p}<0.01 ; * * * \mathrm{p}<0.001 ; * * * * \mathrm{p}$ $<0.0001$.

On day 35 after injury and NPC transplantation, we sacrificed all animals and subjected spinal cords to histological analysis. We double immune-stained longitudinal spinal cord sections, including the epicenter of the injury, a segment rostral, and a segment caudal to the lesion, with $\beta$-III-tubulin and GFAP (representative images shown in Figure 37 and 38, respectively). The quantification of the positive staining for $\beta$-III-tubulin at each segment, Rostral Caudal, and at the epicenter of the lesion site (Figure 37, C) revealed higher preservation of $\beta$-III-Tubulin 
fibers in $\mathrm{TLR}^{-/-}$and $\mathrm{TLR}^{-{ }^{--}}$animals with WT-NPC transplantation in comparison with the WT recipient animals.

Moreover, WT-NPC transplantation in $\mathrm{TLR}^{-/-}$animals showed smaller scars than non-transplanted TLR2 deficient animals (Figure 38, C). These results indicate that transplantation of NPCs in the presence of either TLR2 or TLR4 has reduced neuronal preservation capabilities and reduces the expansion of the inhibitory scar. 
A)

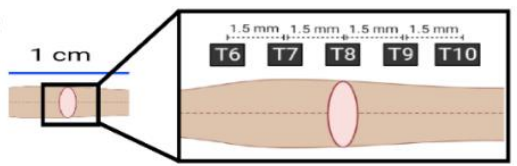

B)

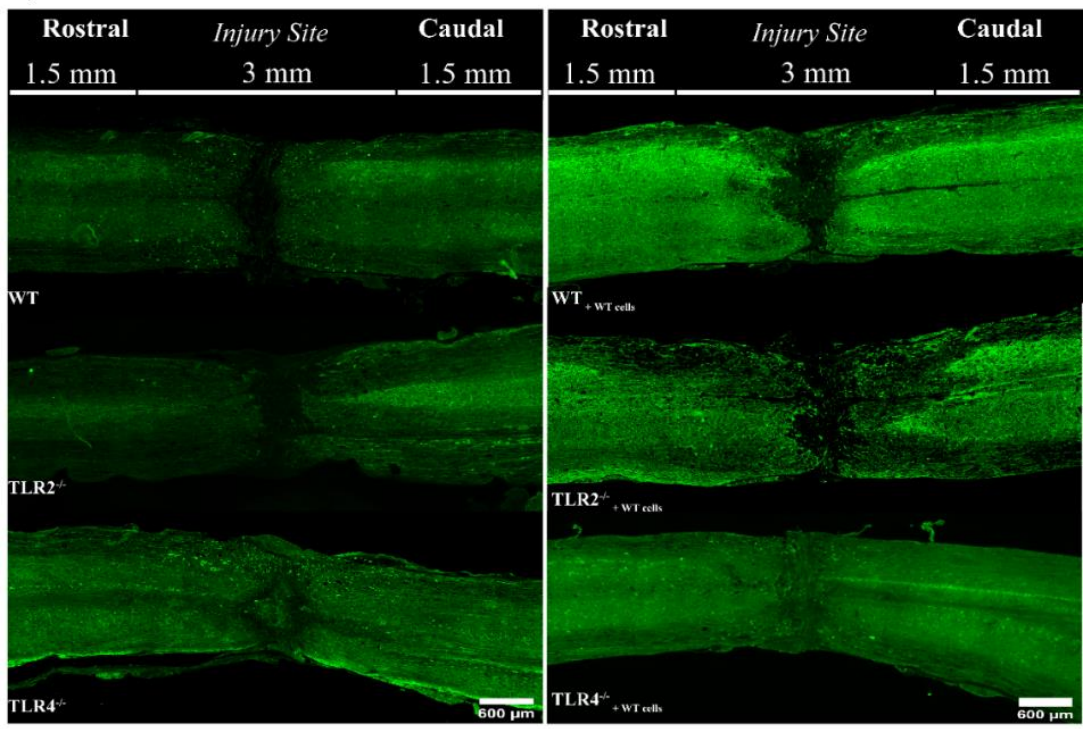

C)
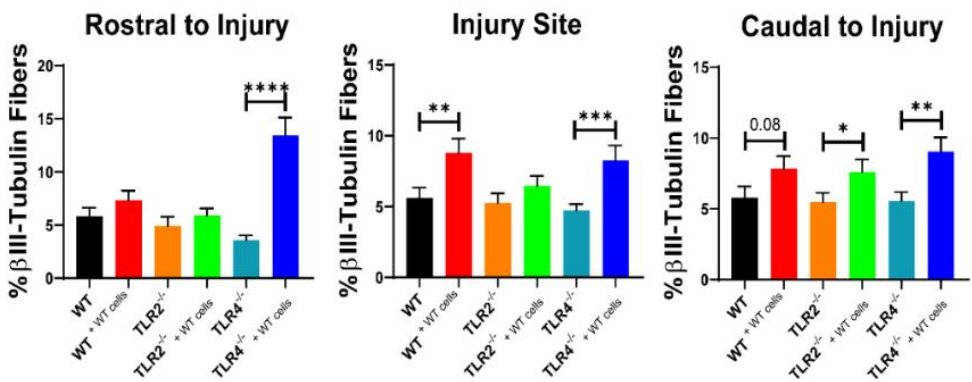

Figure 37. Histological analysis of neural fibres labelled with $\beta$ III-Tubulin from WT and $\mathrm{TLR2}^{-/-}$or TLR4 ${ }^{-/-}$animals with WT-NPCs transplantation.

A) Representative schematic of the spinal cord fragment chosen for analysis. For analysis the spinal cord was subdivided into $1.5 \mathrm{~mm}$ fragments equivalent to the distance between vertebrae in the mouse spinal cord. B) Representative immunofluorescence images of $\beta$-III-tubulin of longitudinal spinal cord 
sections including the $3 \mathrm{~mm}$ injured area and $1.5 \mathrm{~mm}$ of rostral and caudal area close to the lesion from WT (upper images), TLR2 $2^{-/}$(middle images) and TLR4 $^{-/-}$(lower images) without cell transplantation (on the left) and with WT cell transplantation (on the right) 5 weeks after SCI (scale bar $600 \mu \mathrm{m}$ ). C) Quantification of $\beta$-III-tubulin positive fibres in the rostral, injury and caudal area represented as a percentage of the total analysed area. Results assessed for normality using the Shapiro-Wilk test and two-way ANOVA with Sidak post hoc test. Data are shown as mean \pm SEM ( $n=4$ animals per group). $* \mathrm{p}<0.05$; $* * \mathrm{p}<0.01 ; * * * \mathrm{p}<0.001$. 
A)

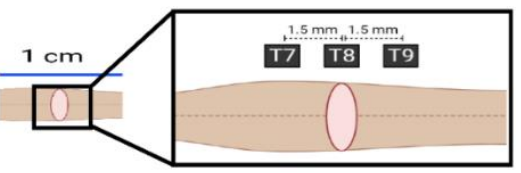

B)

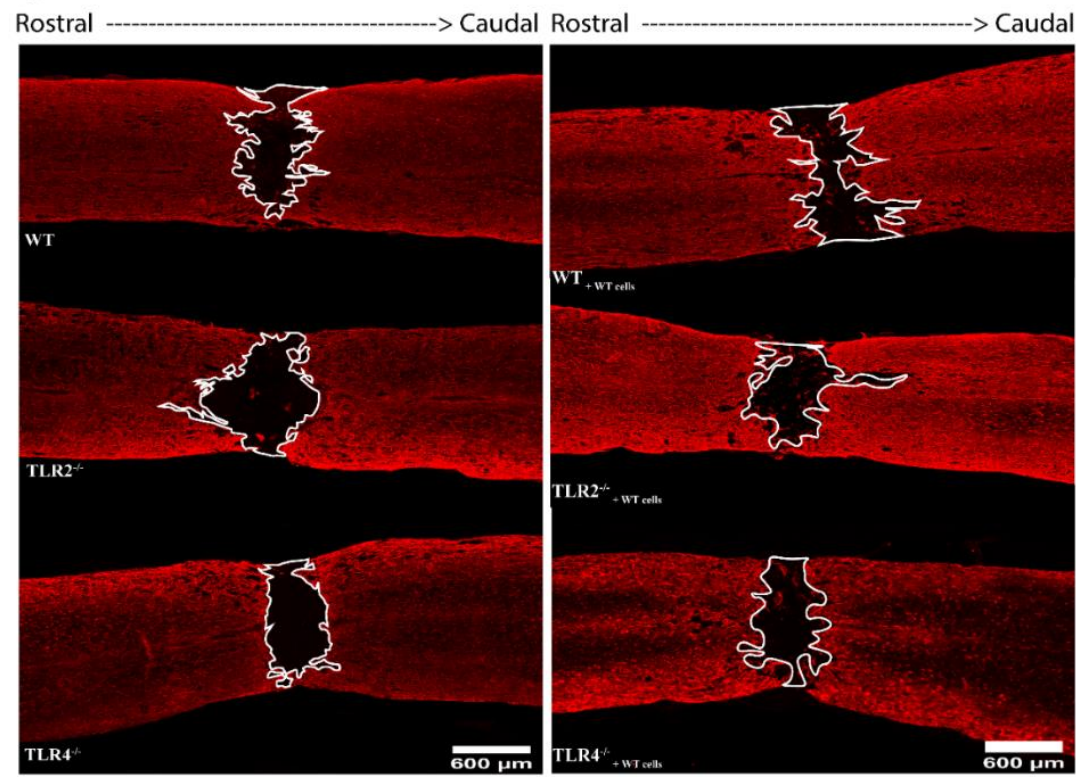

C)

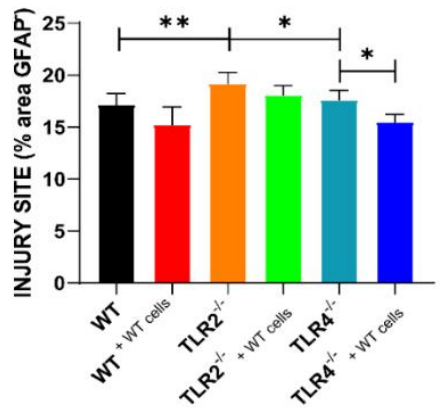

Figure 38. Histological analysis of fibrotic scar by delimitation of the area negative for GFAP staining from WT and TLR2 ${ }^{-/-}$or TLR4 ${ }^{-/-}$animals with WT-NPCs transplantation. A) Representative schematic of the spinal cord fragment chosen for analysis. For analysis the spinal cord was subdivided into 
$1.5 \mathrm{~mm}$ fragments equivalent to the distance between vertebrae in the mouse spinal cord. B) Representative immunofluorescence images of GFAP of longitudinal spinal cord sections including the $3 \mathrm{~mm}$ injured area from WT WT (upper images), TLR2 ${ }^{-/}$(middle images) and TLR4 ${ }^{-/-}$(lower images) without cell transplantation (on the left) and with WT cell transplantation (on the right) 5 weeks after SCI (scale bar $600 \mu \mathrm{m}$ ). C) Quantification of GFAP negative area represented as a percentage of the total analyzed area $(3 \mathrm{~mm})$. Results assessed for normality using the Shapiro-Wilk test and two-way ANOVA with Sidak post hoc test. Data are shown as mean \pm SEM ( $n=4$ animals per group). $* \mathrm{p}<0.05 ; * * \mathrm{p}<0.01$.

Protein expression analysis above the lesion epicentre, in rostral segments, (see detailed description in Material and Methods) indicated a significant increase of ED-1, infiltrated macrophages marker and Iba-1, microglia marker, in the group of animals transplanted with NPCs in TLR2 or TLR4 deficient mice. Figure 39 shows the quantification plots of rostral (Figure 39, A) and caudal (Figure 39, B) western blot normalised to their own control without cell transplantation (normalized to 1 , dotted line), to observe the differences that transplantation has on WT, TLR2 or TLR4 deficient mice. We observed the upregulation of iNOS expression, induced in an inflammatory environment, in all transplanted groups (Figure 39). However, we observed the downregulation of all inflammatory markers evaluated were in all transplanted groups in the caudal segments below the lesion site (Figure 39). 
We failed to find any differences in BDNF in the rostral spinal cord; however, in TLR4 ${ }^{-/-}$with WT-NPC transplantation, caudal spinal cords have a higher expression of BDNF than $\mathrm{TLR}^{-/-}$animals and with the effect caused by WT-NPC in WT and TLR2 ${ }^{-/-}$animals. These results reinforce the hypothesis that BDNF act by TLR4 to enhance neural recovery through cell transplantation (312,313). NPC transplantation in the rostral area increase the cFOS protein level, however, only WT-NPC transplanted on WT animals can increase cFOS protein level in caudal proteins, showing that WT-NPC promote axon regeneration in all three animal phenotype (314). We did not find differences in the antiapoptotic protein BCL2, but we observed higher activity of caspase 3 after NPC transplantation in WT and $\mathrm{TLR}{ }^{--}$animals. However, in the caudal part, animals with NPC transplanted shown lower level of Caspase 3. These results indicate that NPC transplantation increased cell death by TLR2 in the transplant area. We observed no significant differences in rostral ERK activation between animals with and without transplantation. However, we found a significant increase in ERK activity in TLR $4^{-/}$animals after cell transplantation compared to $\mathrm{TLR}^{-/-}$animals without cells, with this activation leading to increased proliferative activity. Finally, we found an increase of STAT3 in the rostral part in WT and TLR4 ${ }^{-/-}$animals with transplantation, but a decrease in the caudal part. 
Chapter 2: Results

A)

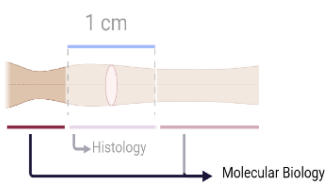

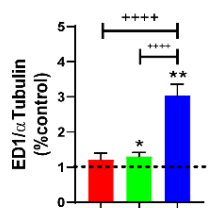

$2 a^{250}$

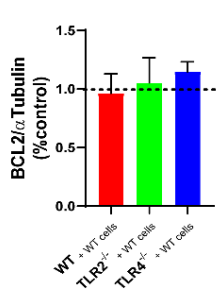

B)

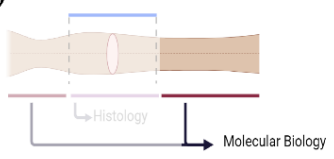

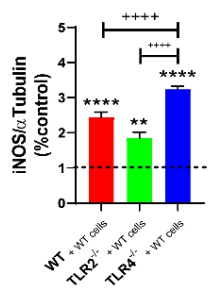
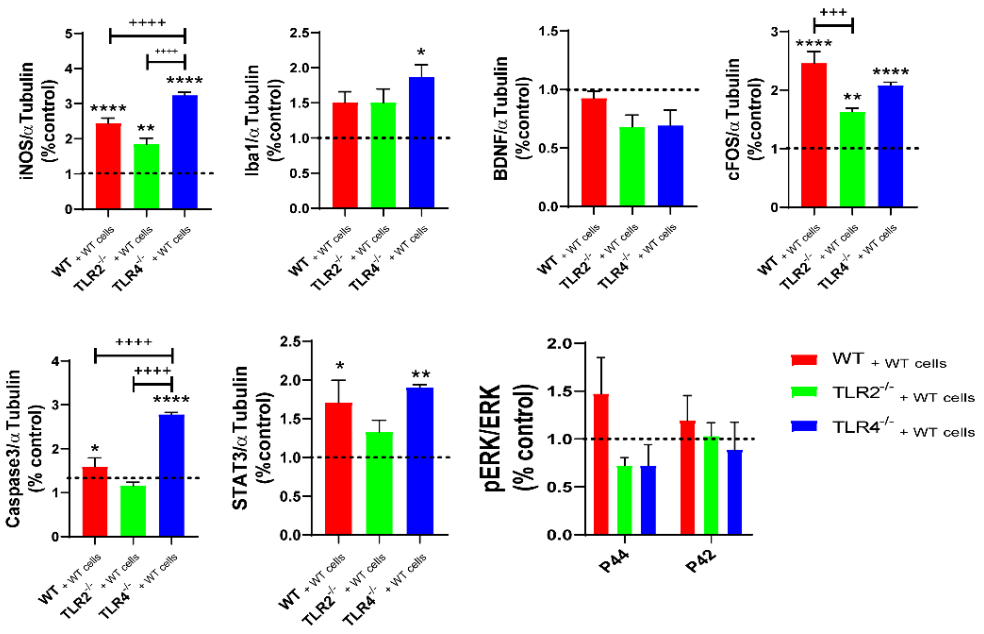
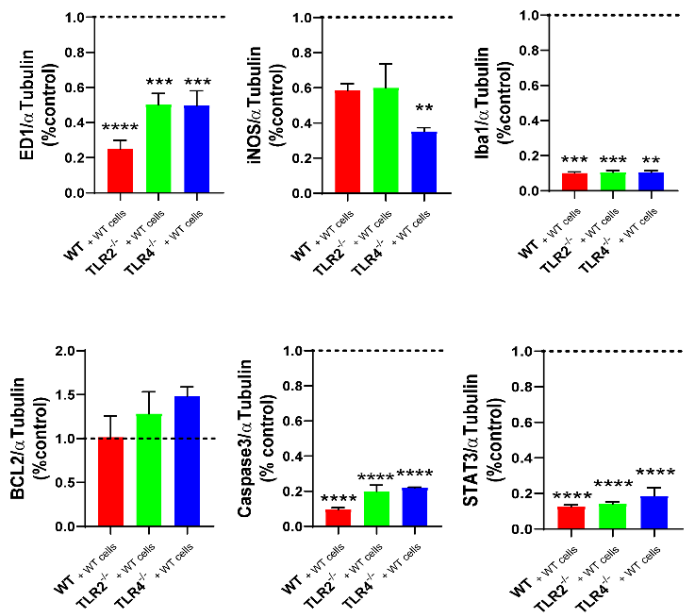
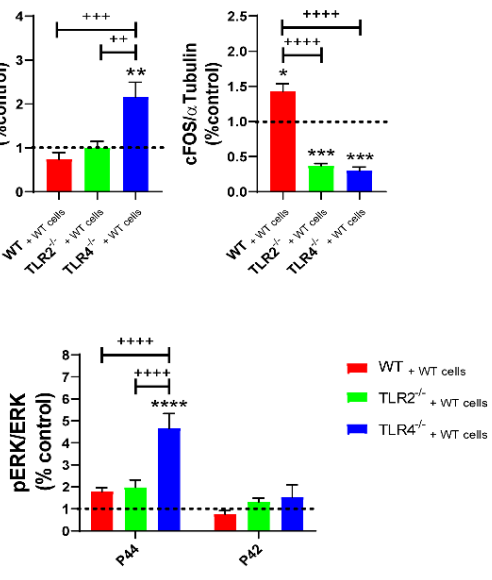
Figure 39. Western blotting analysis of the protein extracts from rostral (rSC) and caudal (cSC) regions of spinal cords from WT, TLR2 ${ }^{-/-}$and TLR4 $^{-/}$animals transplanted with WT-NPC transplantation. A) Quantitative protein level of rostral regions of spinal from animal + WT cell transplantation normalized with $\alpha$ Tubulin as loading control in comparison with WT, TLR2 ${ }^{-/-}$or TLR $4^{-/-}$control groups (represented by dotted line and normalized to 1. B) Quantitative protein level of caudal regions of spinal from animal + WT cell transplantation normalized with $\alpha$ Tubulin as loading control in comparison with WT, TLR2 ${ }^{-/-}$or TLR4 ${ }^{-/-}$control groups (represented by dotted line and normalized to 1 . Results were assessed for normality using the Shapiro-Wilk test and one-way ANOVA with Tukey post hoc test was used to analyse differences between groups. Data are shown as mean \pm SEM ( $n=4$ samples per group). * vs own control (WT, TLR2 ${ }^{-/-}$or TLR $4^{-/-}$animals) and + vs animals + WT cell transplantation. 1 symbol $\mathrm{p}<0.05 ; 2$ symbols $\mathrm{p}<0.01$; 3 symbols $\mathrm{p}<0.001 ; 4$ symbols $\mathrm{p}<0.0001$. 


\subsection{Discussion}

Cell transplantation therapy employing NPCs is conceptually, an attractive strategy for traumatic SCI to replace lost cells, remyelinate host axons and promote tissue sparing (reviewed by (315)). However, the major limitation remains on their poor capacity to integrate, survive and differentiate which is conditioned by the host damage microenvironment (reviewed by (174)).

$\underline{\text { TLR} 4 ~ a n d ~ i n ~ a ~ l e s s ~ e x t e n d ~ T L R 2, ~ a r e ~ n e e d e d ~ d u r i n g ~}$ spontaneous regeneration after spinal cord injury

In the first experimental approach, we studied the influence of TLR2 and TLR4 on spinal cord injury. For this purpose, we used a severe compression model generating a complete spinal cord injury in WT and deficient mice for TLR2 or TLR4. To study the spontaneous regeneration of the animals, they were kept for 35 days with the post-surgical care explained in Materials and Methods and passive and active rehabilitation during the whole experiment.

Based on previous evidences, we hypothesized that modulation of TLR-mediated signalling after SCI, playing a key role modulating the primary inflammatory response in the absence of pathogens, would improve functional recovery as well as improve tolerance and integration to transplantation. Impellizzeri et al. demonstrated that TLR4 play an important role 
in the first defence response during the secondary damage that occurs immediately after the injury. TLR4 deficient mice developed severer hind limb motor dysfunction and neuronal death and had an increase of MYD88, NFkB activity, TNF $\alpha$, IL1 $\beta$ and iNOS expression compared to WT mice. SCI in TLR $4^{-/-}$mice causes a decrease in IFN $\beta$ releases because of the decrease in phosphorylated IRF3. These animals showed an up-regulation of apoptotic proteins (Bax) and a down-regulation of BCL-2 compared to injured WT mice. Therefore, its well described that TLR4 is important for coordinating post-injury sequel and in regulating inflammation after SCI (137). TLR4 shows divergent effects after PNS damage as well. The absence of TLR4 also causes impaired motor recovery after peripheral nervous system damage. After nerve axotomy, upregulation of TLR4 causes an increase of astroglial and microglial reaction and lead to synaptophysin downregulation enhancing synapse loss of spinal motoneurons (316). Also Marques Freria et a.l demonstrated that TLR2 expression led to greater synaptic loss, being correlated with an increased astrogliosis and with an upregulation of proinflammatory interleukins and TLR2 absence, resulted in the upregulation of neurotrophic factors after sciatic nerve transection (317). More recently in SCI, increased TLR2 expression in astrocytes via $\mathrm{NF \kappa B} / \mathrm{PI} 3 \mathrm{~K}$ promotes functional recovery by acting on fibrotic scar molecules such CSPG after Schwann cell-derived exosomes treatment (318). However, it is still not entirely clear by which mechanisms they work. 
TLR4 deficient mice fail to evoke immunoregulatory mechanisms increasing the inflammatory response (319). Further, The increases of chemokine expression such CCL2 and CCL3, in TLR2 deficient mice could lead leukocyte trafficking and monocyte infiltration at the injury site modifying injury site environment (122). Our data evidenced the relevance of TLR2 and TLR4 expression for spontaneous regeneration in the adult mice after SCI. These data are consistent with previous studies done by Popoviich's lab $(122,138)$, demonstrating that both TLRs may be involved in regeneration mechanisms after injury such as the activation of endogenous NPC, such OPCs, and producing a microenvironment more feasible to cell migration and neurite outgrow.

Five weeks post-injury, TLR $4^{-/-}$animals showed a worse motor recovery compared to WT and TLR2 $2^{-/}$animals in the BMS score and Duty Cycle in the CatWalk analysis. Histological analysis showed a decrease in preserved $\beta$-III-Tubulin positive fibers in the whole spinal cord, being those more marked in the area rostral to the lesion, fact that could explain the poor functional recovery in TLR $4^{-/-}$mice after injury. Whether the deficient neuronal fibers or by contrast, the preserved ones involve relevant ascending and or descending sensory or motor circuits needs to be further explored. Molecular analysis with protein levels assays show that TLR $4^{-/}$animals have a lower recovery function accompanied with an increased secondary 
tissue damage marked by increased iNOS $(137,307)$ which is reflected in the decrease of $\beta$-III-Tubulin positive fibers caudal to the injury. iNOS increased can be due to $\mathrm{NF \kappa B}$ activation previously reported by $\mathrm{Xu}$ et al. (307) which induce apoptotic cell death in neurons, oligodentrocytes, and astrocytes (320). Interestingly, we observed a decrease in the proinflammatory reaction by macrophages/microglia (ED1 and IBA1 marker) in the rostral part, indicating that the absence of TLR4 at least in part, promotes a phenotype with less inflammatory reaction from macrophages as we expected in line with the studies of Zang (319) . This fact deserves further attention with additional experiments to better understand if the lack of pro-inflammatory markers is accompanied by anti-inflammatory macrophage/microglia markers as well.

$\mathrm{TLR}^{-/-}$animals showed functional recovery and fiber preservation in a similar way to WT animals although we found a slight increase in scar area. However, other authors have shown that TLR2 ${ }^{-/-}$animals have lower subscores of BMS due in part to deficits in coordination (321), so we would need to perform this analysis in more depth. On the other hand, TLR2 ${ }^{-/-}$animals show an increase in cFOS and BDNF indicating that the increase in these two factors is indicative of an increase in neuronal activity $(322,323)$ are upregulated in absence of TLR2. However, the functional improvement of these $\mathrm{TLR}^{-/-}$animals remains unchanged as WT animals because they show increased 
proinflammatory response with the upregulated expression of iNOS suggesting higher secondary damage and scar formation linking TLR2 expression to the astrocyte reaction (318) in accordance with the observed increased activation of ERK (324) and STAT3 $(324,325)$.

TLR2 and TLR4 involvement in the NPC transplantation tolerance in a model of SCI

In the second experimental approach, our main objective was to study the combination of NPCs derived from neonatal TLR2 ${ }^{-/-}$or TLR $4^{-/-}$mice in WT hosted mice. For this purpose, we used the same lesion model described in approach 1, and NPCs (300.000 cells) was used as a therapeutic strategy transplanted rostral to the lesion immediately after injury. As a control to study how the absence of TLR2 or TLR4 in NPCs interferes with the process of integration and performance of cell transplantation, WT animals were transplanted with WT-NPCs derived from neonatal animals. During the 35 days of the study, like the non-transplanted animals, they were passive and active rehabilitation.

We have shown (see Chapter 1) that TLR2 and TLR4 play an important role in the maintenance of the stem-ness and proliferative status of NPC-derived from mouse neonatal spinal cords, as well as in cell fate decision after differentiation. Here, we have explored whether the absence of any of these receptors 
has an influence of the NPC-derived regenerative capacity transplanted immediately after SCI.

NPCs were transplanted only into the rostral area adjacent to the injury based on the results of Llorens et al. (326) and Iwai et al. (207), where they show that cell survival is better when cells are not transplanted into the epicentre of the lesion. In addition, in the case of a complete lesion, as we see in the volume of the spinal cord, the caudal area suffers Walerian degeneration (327) that would not allow the correct integration of the cells (162). We therefore transplanted 300,000 cells in the area rostral to the lesion focus only on differences due to transplantation of NPCs in the absence of TLR 2 or TLR4. We observed that the 3 cell types are able to integrate and migrate in the tissue, finding cells after 5 weeks of lesion. However, our results show that TLR2 $^{-/-}$NPCs have a lower tissue integration, with fewer cells found in compared to WT animals. Transplantation of TLR2 $2^{-/}$ NPCs shows a decrease in functional recovery compared to animals transplanted with WT or TLR4 ${ }^{-/-}$NPCs with a larger lesion area caused by STAT3 upregulation caudal to the lesion. The absence of TLR4 in NPC enhances a better preservation of neural fibres in the caudal region and produce an additional increase of BDNF in rostral region which may be beneficial for the survival and maintenance of neural functions (312). In the third experimental approach, the aim was to study the therapeutic capacity of TLR2 and TLR4 in transplanted NPCs in 
SCI. We used the same injury model as in approach $\mathbf{1}$ and $\mathbf{2}$, transplanting 300,000 NPCs derived from neonatal WT animals rostral to the injury immediately after injury in WT, TLR $2^{-/-}$and TLR $4^{-}$mice. The aim is to study whether WT cells have the capacity to restore or enhance the deficits found in the spontaneous recovery of knockout animals. This would attribute a specific role to TLR2 and TLR4 in the regeneration of spinal cord injury mediated by cell transplantation. During the 35 days of the study, like the non-transplanted animals, they were passive and active rehabilitation

In order to study the capacity of TLR 2 and TLR 4 in NPCs, WT NPCs were transplanted into TLR2 $2^{--}$and TLR4 $4^{-{ }_{-}}$animals to explore the improvements that occurred. With BMS test, we did not observe a significant improvement with WT NPC transplantation. However, we observed that TLR $4^{-/-}$animals with NPC transplantation have a better recovery in comparison with $\mathrm{TLR}^{-/-}$animals. TLR4 ${ }^{-/-}$animals show a greater deficit in motor recovery than WT animals, so it may be easier to find a functional improvement with NPC transplantation. Church et al. demonstrated that the greater demyelination produced in TLR4deficient animals exacerbated the locomotor deficit compared to WT animals (141). In addition, several studies have shown that NPCs are able to differentiate into oligodendrocytes and promote remyelination after spinal cord injury $(293,328)$, which could explain this improvement. 
In the rostral part of the spinal cord, we found an increase in iNOS indicating higher secondary damage caused by NPC transplantation, although transplanted-NPC provoke an upregulation of c-FOS compared with animals without transplantation. interestingly the one with the most strikingly increased macrophage/microglial infiltration reaction is in the $\mathrm{TLR}^{-/-}$animals transplanted with NPC compared to TLR4 ${ }^{-/-}$ animals infiltration levels. This increase is due to the transplantation of the cells, which produce an increase in apoptosis. Despite this, an increase in STAT3 as well as ERK and BDNF is observed, could indicate a better neural activity and neuronal preservation in part to the release of trophic factors secreted by the cells, which are sufficient to recover the functional capacity of the $\mathrm{TLR}^{-/-}$animals. With these data we found a very reactive environment in the rostral area where the cells were injected, but the transplantation of cells in the 3 types of animals generated an environment that favoured the recovery of the lesion.

Overall, we found that TLR2 and TLR4 are necessary during the certain spontaneous regeneration that occurs after spinal cord injury, influencing on the microenvironment generated after injury. Nevertheless, the absence of TLR4, which reduced the inflammatory environment, generate a better response to NPC transplantation, with better functional outcomes. Additional analysis on the macrophage- and microglia 
phenotypes in the absence of TLR4, with a potential proregenerative role, could be a key mechanism for neuronal recovery which needs to be further investigated. 


\section{CHAPTER 3}

CSPG MODULATE MACROPHAGES POLARIZATION VIA TLR4 IN VITRO

VALIDATION 


\subsection{Introduction}

Traumatic SCI results in the development and consolidation of a fibrotic scar surrounding the edge of the lesion. Glial scars comprise of two distinct parts: the lesion core and the lesion border. At early stages, microglia contributes to scar formation by suppressing factors that activate astrocytes (329). In the mature glial scar in the chronic phase of injury, the lesion core consists of multiple cell types, including fibroblasts, macrophages, and $\mathrm{NG}^{+} \mathrm{OPCs}$, whereas the lesion border chiefly contains reactive astrocytes, $\mathrm{NG}^{+} \mathrm{OPCs}$, and microglia (330)(331). These cells and the ECM molecules they release can trigger the inflammatory response of stromal cells, astrocytes, OPCs, and microglia (332). Finally, this cascade prompts the development of the fibrotic scar.

During this stage of scar formation, reactive astrocytes proliferate, undergo hypertrophy, and secrete one of the main components of the scar, CSPGs (333). CSPGs inhibit axonal regeneration and downregulate neuronal plasticity (159). Released CSPGs activate receptors on macrophages/microglia to induce a pro-inflammatory phenotype during the first two weeks after injury, and in turn, increasing inflammation induces further astrocytic reactivity and CSPG deposition (334). While scars in other tissues generally resolve, CNS scars are long-lasting (335). Specifically, the glial scar formed in an SCI lesion contains 
various cell types and non-neural and extracellular components that prevent axonal regeneration (336). Recent evidence suggests that CSPGs play a crucial role in modulating immune cell responses in chronic inflammatory and demyelinating disorders of the CNS $(337,338)$. CSPGs may also contribute to the pathological neuroinflammatory response after SCI due to their abundant expression and interaction with different cell types after SCI (159). CSPGs play a pivotal role in repairing the injured spinal cord and improving motor function during the acute phase after the injury. CSPG has a beneficial role in the early stages of SCI and a deleterious effect at later stages by retaining endogenous molecules involved in spinal cord repair (339).

In 2002 Bradbury and collaborators first evidenced the use of Chondroitinase $\mathrm{ABC}(\mathrm{Ch} \mathrm{ABC})$, a bacterial enzyme that digests the sulfated glycosaminoglycan chains of CSPG, to remove their inhibitory properties after SCI (340). Subsequent promising studies showed increased plasticity $(341,342)$, neuroprotection (343), and functional recovery following SCI $(340,344)$.

CSPGs have a pro-inflammatory role after SCI $(345,346)$; however, degradation with $\mathrm{ChABC}$ promotes an antiinflammatory response through infiltrated macrophages with an increase of IL10 after SCI (345). Studies in ALS and autoimmune encephalomyelitis revealed the upregulation of CSPGs within inflammatory lesions, particularly in "the leucocyte-containing 
perivascular cuff" where immune cells accumulate and enter the CNS (347). This finding suggested the involvement of CSPGs in immune modulation by promoting a pro-inflammatory response in the CNS; however, the cellular and molecular mechanisms associated with CSPGs have yet to be elucidated.

These findings fostered new research into CSPGs and their two principal receptors - leukocyte common antigen-related phosphatase (LAR) and receptor protein tyrosine phosphatase $(\mathrm{PTP} \sigma)$. The interaction of CSPGs with LAR inactivates AKT and activates Rho, resulting in axonal growth inhibition (348). Activation by the PTP $\sigma$ receptor leads to axonal inhibition by CSPG. Interestingly, heparan sulfate promotes binding to the same receptor to prompt axonal regeneration (349). CSPGs can also interact with CD44 in microglia to activate ERK1/2 phosphorylation (339). Interestingly, CSPG levels became significantly reduced following the administration of a TLR9 antagonist (ODN 2088) in SCI model mice (350).

While TLR2 and TLR4 can bind to ECM molecules such as versican and biglycan, we do not fully understand what induces these effects - the core protein or the chondroitin sulfate structure shared with CSPG (351). Moreover, the heparan sulfates, chondroitin 4-sulfate with a monosulfated unit at the C-4 position, and chondroitin 6-sulfate molecules significantly inhibit MyD88, TRAF-6, and NFאB activation, inflammation cytokine release, 
Chapter 3: Introduction

and iNOS activity after TLR4 activation by LPS in mouse chondrocytes (352).

Signaling through CSPG by resident glia and innate immune cells has also been explored (353); however, their role in macrophage phenotypic polarization and activation via TLRs remain unclear. Therefore, this chapter aims to study the effect of CSPG on the macrophage phenotypic polarization in vitro and the potential role of TLR4 response in this process. 


\section{Bone Marrow derived Macrophages from Rats}

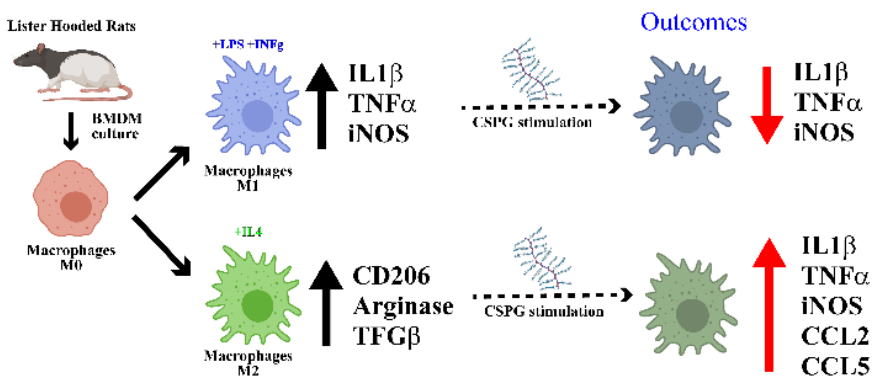

Bone Marrow derived Macrophages from TLR $4^{-M i c e}$

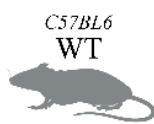

C57BL6

TLR4
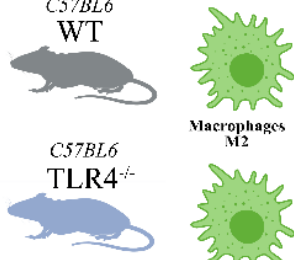

vacrophages

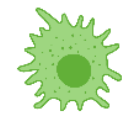

Macrophages

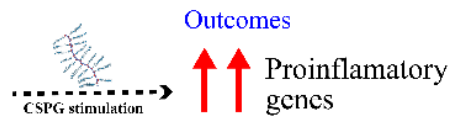

(CSPG stimulation

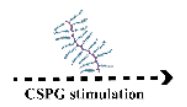
n.d. Proinflamatory
genes
Main outcome

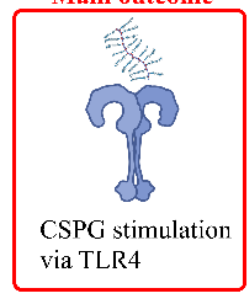

CSPG stimulation via TLR4

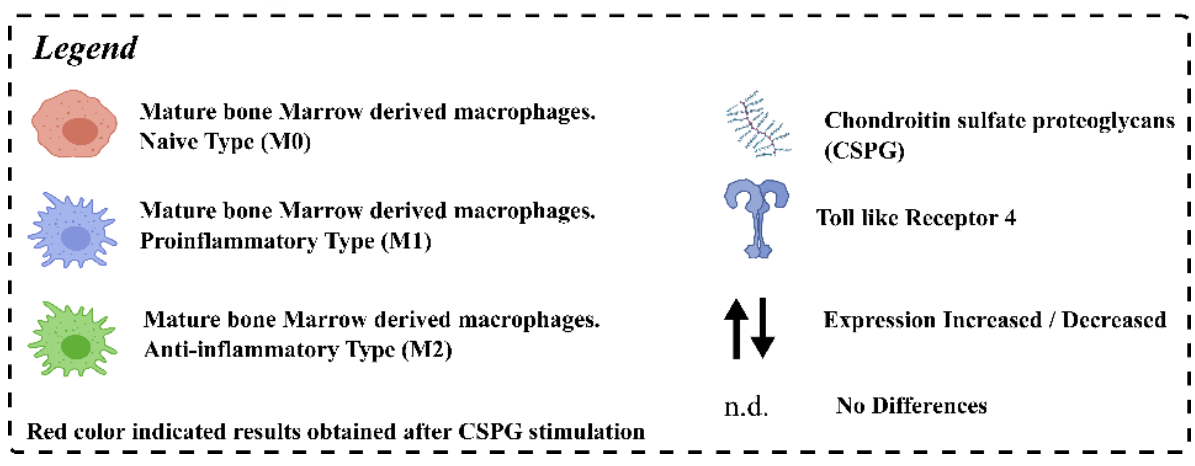

Figure 40. Chapter 3 graphical abstract 


\subsection{RESULTS}

\subsubsection{CSPG mediated the phenotypic conversion of BMDM from anti-inflammatory to pro-inflammatory}

We extracted bone marrow-derived macrophages (BMDMs) from femurs and tibias of Lister Hood female rats and cultured them in M-CSF presence for six days. After correct differentiation of monocytes to non-polarized macrophages (M0), they were polarized towards a pro-inflammatory (M1) and antiinflammatory (M2) macrophage profile to study the effect of CSPG on them. We incubated BMDM-M0 with growth media + LPS and INF $\gamma$ to develop a pro-inflammatory phenotype and growth media + IL4 to develop an anti-inflammatory phenotype (both without M-CSF) (Figure 41, A). We performed gene expression experiments to analyze the proper polarization showing an increase in CCL5 and IL1 $\beta$ genes in M1 compared to $\mathrm{M} 0$ and M2, as well as an increase in the iNOS/Arg1 ratio (Figure 41, B), these being classic markers of the M1 phenotype and an increase in TGF $\beta$ and CD206 in M2 (Figure 41, C) compared to M1, M2 classic markers (354). The results confirm a correct polarization of the cells. 
A)

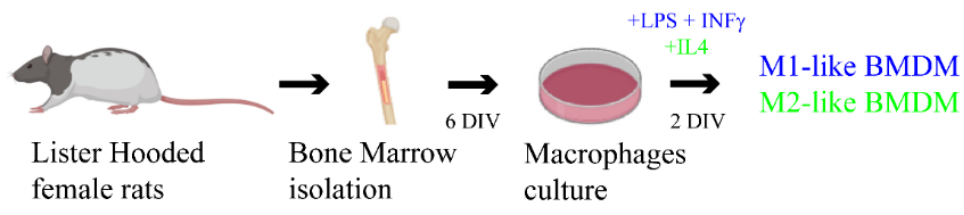

B)
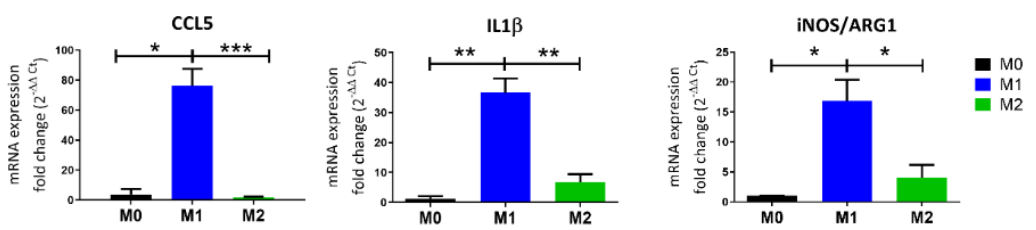

C)
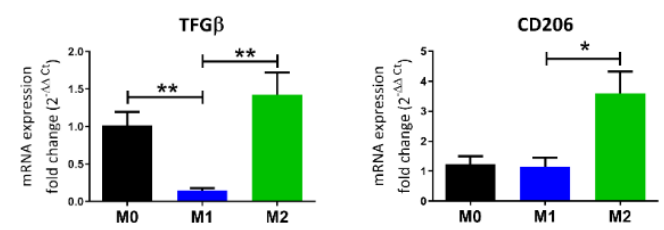

Figure 41. BMDM Polarization into M1 and M2 phenotype. A) Schematic representation of BMDM culture. B) mRNA levels of inflammatory response genes CCL5, IL1 $\beta$, and iNOS/Arg1 ratio in BMDM M0, M1, and M2. C) mRNA levels of anti-inflammatory response genes TGF $\beta$ and CD206 in BMDM M0, M1, and M2. Results assessed for normality using the ShapiroWilk test and analyzed using a two-tailed unpaired t-test. Data shown as mean \pm SEM ( $\mathrm{n}=6$ per group).

To assess the effects of CSPGs on a mature macrophage population, we incubated BMDMs polarized into M1-like or M2like phenotypes in the presence of soluble CSPGs in the culture medium. For this purpose, we studied the gene profile of BMDMs after activation with CSPGs at a short time (4 hours) and at a long 
time (16 hours) to observe how a prolonged response is maintained. In both times we observed in the heatmaps that there are more changes at gene level in M2-like BMDM than in M1like BMDM after activation with CSPGs (Figure 42, $\mathbf{A}$ and D). At 4 hours CSPGs treatment promotes a slight reduction of inflammatory-related gene expression in M1 macrophages (Il1 $\beta$, TNFa, NLRP3, CCL3, CXCL10, IL6, and COX2) (Figure 42, B). CSPGs on M2 BMDM has an effect that enhances the gene expression of inflammatory cytokines (I11 $\beta$, CXCL0, IL6, CCL5), enzymes involved in inflammatory pathways (COX2), or phenotype (iNOS), and genes involved in TLRs pathways (NFkB1a and IRF7) (Figure 42, C). Although in M1, we observe at later times, 16 hours, an increase in the expression of Caspase 1 , enzyme involved in the proteolytic cleavage of IL1 $\beta$ (Figure 42, E). Also, in M2, we observe a small increase in ReLA, involved in the TLR4 and MHC2 pathways (classically used to distinguish M1 from M2 (355) (Figure 42, F).

These results indicate that CSPG treatment significantly reverted their anti-inflammatory phenotype M2, by increasing gene expression levels of pro-inflammatory cytokines. Given the less pronounced decrease in gene expression in M1 phenotype compared to the magnitude of the increase in gene expression in M2 phenotype, we can conclude that CSPG affects M1 phenotype and maybe reverting it to an M0 state. This effect could be 
explained, at least partly, by sharing the same receptors, blocking them, and reducing the inflammatory activation of those cells.

A)

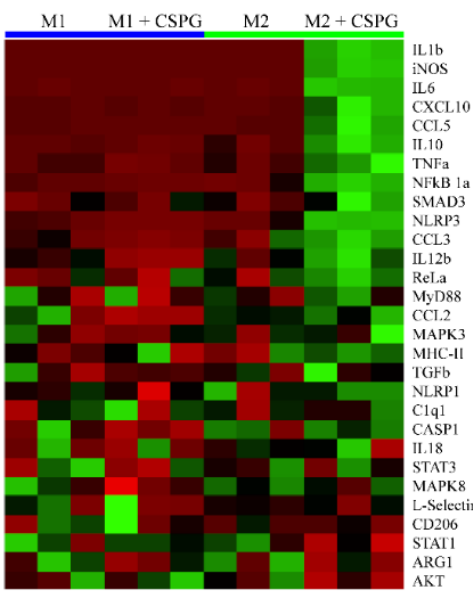

D) 16 hours after CSPG

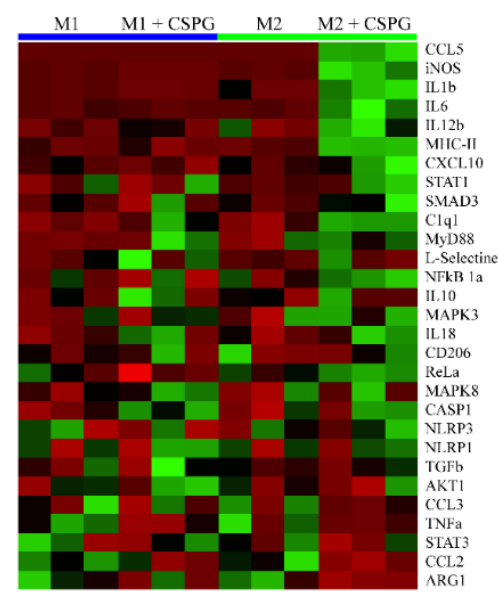

B)

$$
\begin{array}{ll}
\mathrm{M} 1 & \mathrm{M} 2 \\
\mathrm{M} 1+\mathrm{CSPG} & \mathbb{M} 2+\mathrm{CSPG}
\end{array}
$$
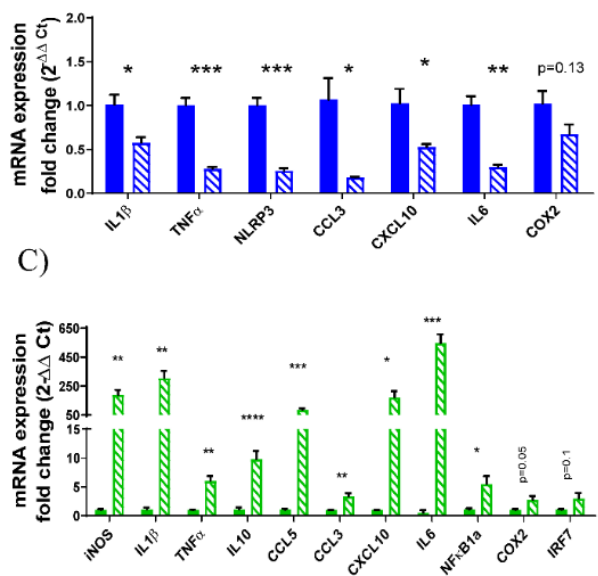

E)
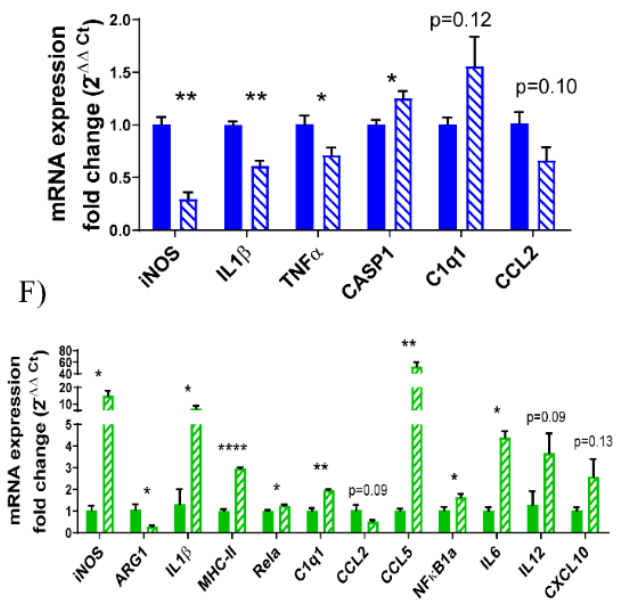

Figure 42. CSPG treatment reverts the anti-inflammatory gene expression of phenotype M2 in BMDM. A) Heatmap showing the effect of 4 hours CSPG 
treatment $(5 \mu \mathrm{g} / \mathrm{ml})$ in M1 (left) and M2 (right) polarized BMDMs. B) Bar graphs showing genes significantly altered by 4-hour CSPG treatment in M1 BMDM. C) Bar graphs showing genes significantly altered by 4-hour CSPG treatment in M2 BMDM. D) Heatmap showing the effect of 16 hours CSPG treatment $(5 \mu \mathrm{g} / \mathrm{ml})$ in M1 (left) and M2 (right) polarized BMDMs. E) Bar graphs showing genes significantly altered by 4-hour CSPG treatment in M1 BMDM. F) Bar graphs showing genes significantly altered by 4-hour CSPG treatment in M2 BMDM. mRNA levels of inflammatory response genes determined by qPCR. *p $<0.05, * * \mathrm{p}<0.01$, ***p $<0.001$, ****p $<0.0001$ vs. control (no CSPG). Results assessed for normality using the Shapiro-Wilk test and analyzed using a two-tailed unpaired t-test. Data shown as mean \pm SEM ( $\mathrm{n}=3$ per group).

Western Blot analyzed molecular mechanisms by which CSPGs modulate macrophage phenotype. We targeted the main inflammatory signaling pathways (NFKB and MAPK) and the activation of IL1 $\beta$ to study the immunomodulatory role of CSPGs on macrophages. We showed that CSPGs treatment significantly upregulated the phosphorylation of p38 in M2 polarized BMDM after both 4 (Figure 43, A) and 16 (Figure 43, B) hours CSPG incubation. However, we did not find differences in the other MAPKs such JNK and ERK, or NFאB. However, we observed a non-significant increase in the protein level of IL1 $\beta(30 \mathrm{kDa})$ and the enzyme that proteolyzes it, Caspase 1, in M2 BMDM after CSPG treatment (M2+CSPG) compared with control (M2) at $4 \mathrm{~h}$. These data suggest that increased gene expression of inflammatory cytokines could be explained by activating the p38 
Chapter 3: Results

pathway in M2 BMDMs following CSPG treatment with a target on IL1 $\beta$ activation.

Altogether, we present a dual role of CSPGs in macrophage activation for the first time, highlighting their importance in blocking the activation towards an antiinflammatory and more reparative phenotype. 
A)
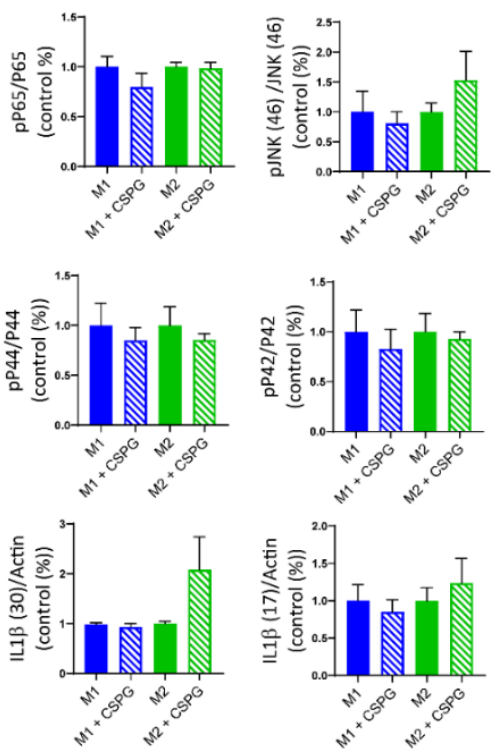

C)
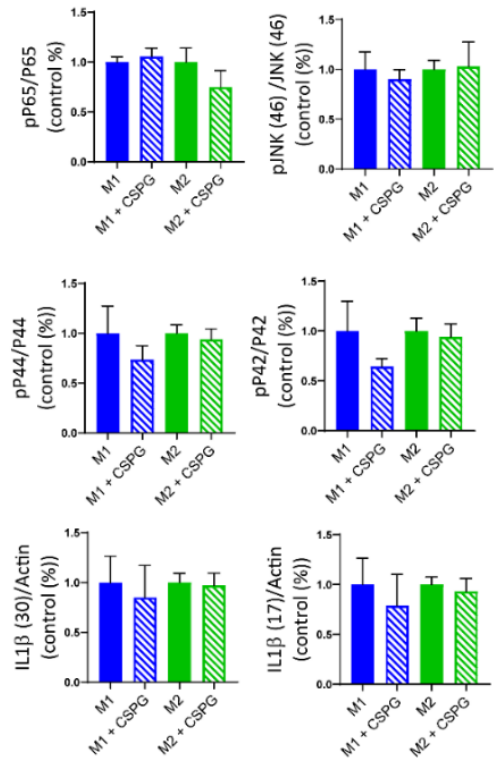
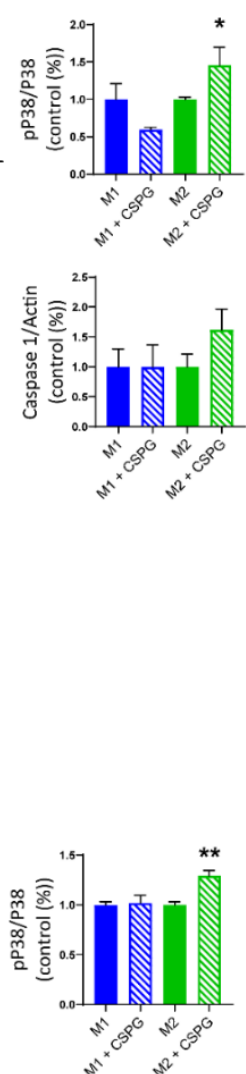

B)

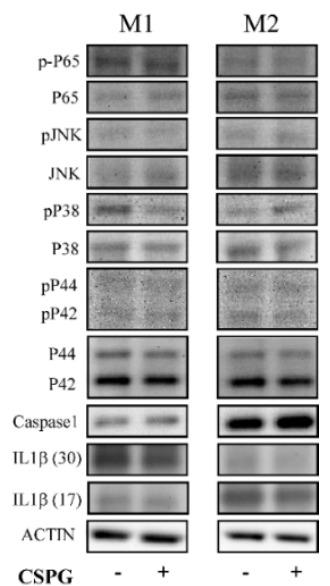

D)
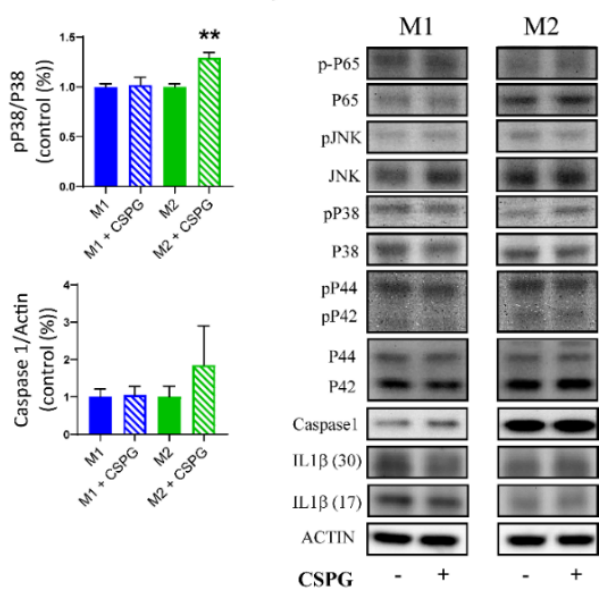

Figure 43. CSPG treatment reverts the anti-inflammatory phenotype M2 in BMDM via P38. A) Quantitative analysis showing IL1 $\beta$ and Caspase 1 
expression and NFKB and MAPKs (JNK, ERK and P38) pathway activation in BMDMs after 4 hours. Data was normalized to own control M1 and M2 without CSPGs. B) Representative image of protein band at 16 hours standardized by densitometry to $\beta$ Actin levels and normalized to own control M1 and M2 without CSPGs C) Quantitative analysis showing IL1 $\beta$ and Caspase 1 expression and NFאB and MAPKs (JNK, ERK and P38) pathway activation in BMDMs after 16 hours. Data was normalized to own control M1 and M2 without CSPGs. D) Representative image of protein band at 16 hours standardized by densitometry to $\beta$ Actin levels and normalized to own control M1 and M2 without CSPGs. Data are shown as mean \pm SEM ( $n=3$ per group) and two-tailed unpaired test was used to analyse differences between treatment conditions.

\subsubsection{CSPG treatment reverts the anti-inflammatory phenotype in microglial cells in vitro but lees in comparison with BMDM}

In an SCI, the first inflammatory response comes from microglia that start to act during the first hours after the injury. In addition, microglia induce the inflammatory response, which is maintained by subsequent macrophage infiltration (356). For this reason, we cultured microglia from both neonatal (p2) and adult rats (10 weeks) to investigate whether we could observe the same immunomodulatory effect of CSPGs in M2 BMDM. After polarized into M2 phenotype and incubate with CSPGs for 4 hours, in both neonatal (Figure 44, A) and adult (Figure 44, B) microglia cultures, we observed an increase in the expression of pro-inflammatory genes of IL1 $\beta$, CCL3, TNF $\alpha$, and iNOS (Figure 44, C), although to a lesser extent than compared to the 
results obtained in macrophages (Figure 42, C). In neonatal microglia, we do not see an increase in CXCL10 after activation by CSPG nor in adult microglia in CCL5. Furthermore, compared to the results obtained in macrophages, we do not observe a significant increase in IL6 and NFאB in both neonatal and adult microglia (Figure 44, C).

In addition to previous data, these results demonstrate that CSPG directly affects inflammatory gene activation in macrophages and microglia, which predominate in macrophages.

A)
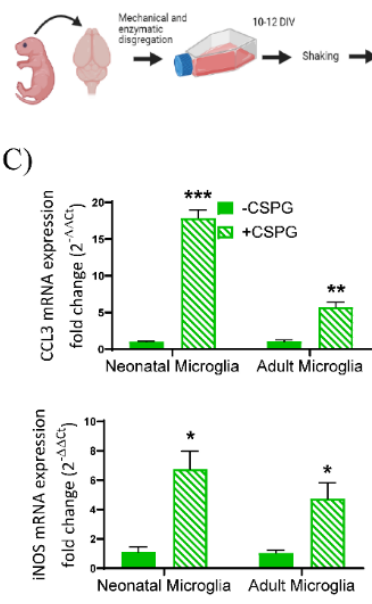

B)

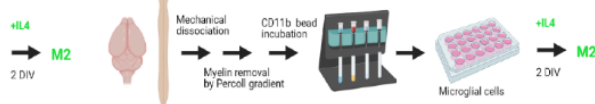

Figure 44. CSPG treatment induces pro inflammatory activation of M2 polarized anti-inflammatory microglial cells. Experimental design of CSPG phenotype conversion studies in M2 polarized A) neonatal and B) adult microglial cells in vitro. C) Bar graphs showing genes altered by CSPG treatment on microglial cells, showing a significant increase in multiple proinflammatory genes in both neonatal and adult polarized microglia. mRNA 
levels determined by qPCR. *p $<0.05, * * \mathrm{p}<0.01$, ***p $<0.001$ vs. control (no CSPGs) group. Results assessed for normality using Student's t-test for single comparisons between the control group vs. +CSPG group, followed by Bonferroni's multiple-comparison tests for more than two groups for normally distributed data. Data shown as mean $\pm \operatorname{SEM}(\mathrm{n}=3$ per group).

\subsubsection{Metabolites derived from BMDMs treated with CSPGs modulate astrocyte}

Astrocytes represent the primary producers of CSPG after SCI. In the fibrotic scar, both astrocytes and CSPG coexist, maintaining a highly reactive and pro-inflammatory environment. ChABC treatment after SCI decreases glial scar and astrocyte reactivity; however, whether the observed effect occurs through CSPG digestion remains unknown. Therefore, we next evaluated if metabolites synthesized by different macrophage phenotypes could modulate astrocyte inflammatory activation and whether this would be affected by CSPG treatment (Figure 45, A).

We first incubated astrocyte cell cultures with conditioned medium collected from M0, M1, and M2 polarized BMDMs without CSPGs. We observed that products synthesized by different macrophage phenotypes modulated the phenotype of astrocytes, whereby metabolites produced by M1 polarized BMDMs significantly enhanced the expression of inflammatory (A1) and reduced anti-inflammatory (A2) markers. Furthermore, metabolites produced by inflammatory M1 BMDMs significantly 
enhanced the expression of inflammatory cytokine mRNA levels in cultured astrocytes (Figure 45, B). We next evaluated the effects of CSPG treatment in modulating M1 and M2 BMDM metabolite release and whether this would influence cytokine mRNA expression by cultured astrocytes (Figure 45, C). We found that inhibition of inflammatory activation exhibited in M1 macrophages by CSPGs is also reflected in astrocytes. We showed a significant reduction of IL6 and CCL5 RNA expression in astrocytes cultured in M1 BMDM conditioned media pretreated with CSPGs, compared with conditioned media from nonpre-treated M1 BMDM.

Metabolites released by M1 BMDMs pre-treated with CSPGs enhanced CCL3 mRNA cytokine expression in astrocytes (Figure 45, D). On the other hand, M2 conditioned media pretreated with CSPGs treatment promotes the up-regulation of most inflammatory cytokine mRNA expression levels (reaching significance in IL1 $\beta$ ) in astrocytes compared with astrocytes cultured with conditioned media from non-pre-treated M2 BMDM (Figure 45, E). These data demonstrate that metabolites produced by different macrophage phenotypes can modulate the activation state of astrocytes and that CSPGs influence the inflammatory activation of astrocytes by macrophages, thereby suggesting that CSPGs play a vital role in the inflammatory response through modulating different cell types, either directly or indirectly, after SCI. 
A)
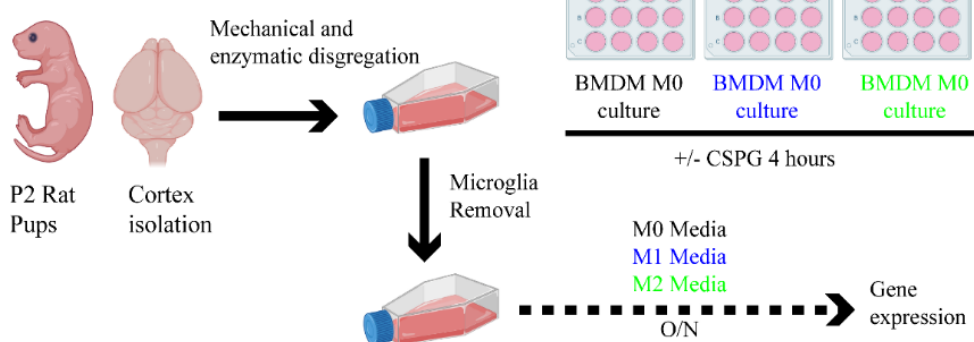

B)

C)
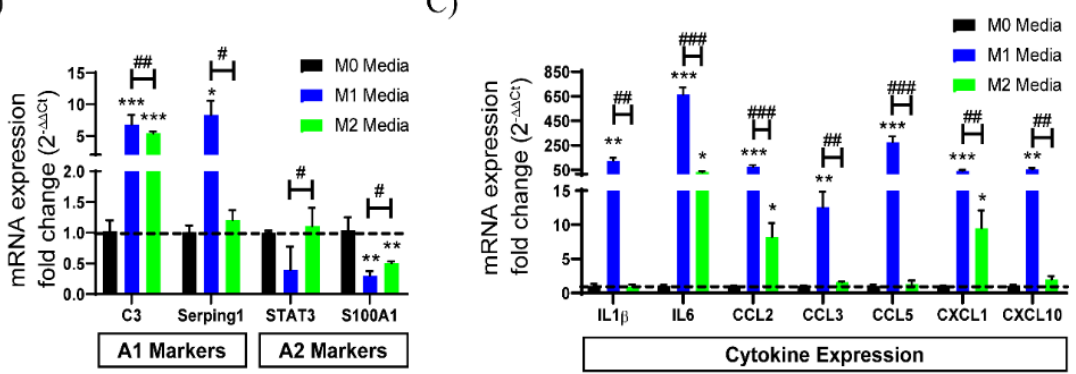

D)

E)
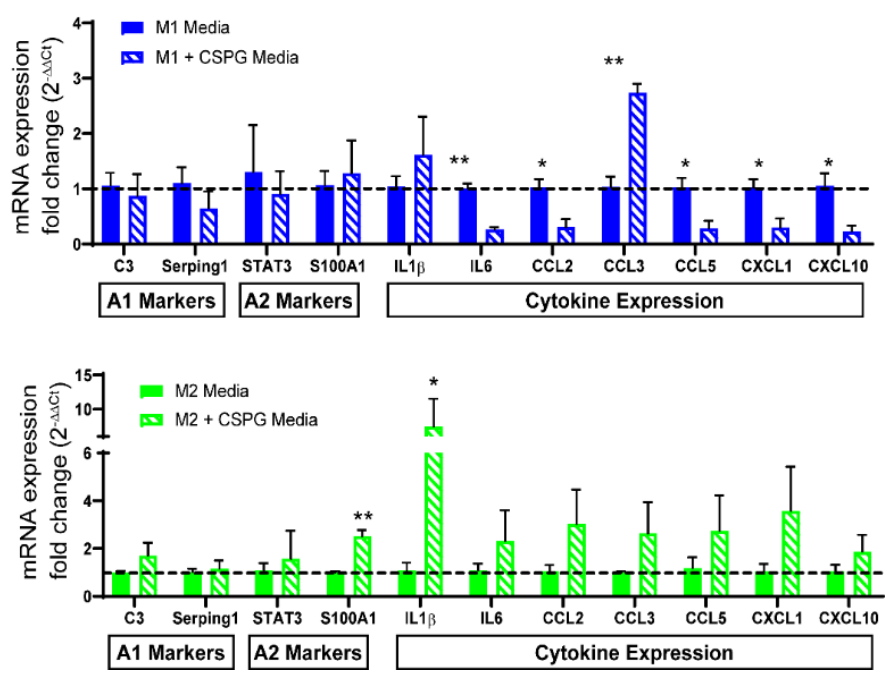

Figure 45. Metabolites derived from BMDMs treated with CSPGSs modulate astrocyte phenotype. A) Experimental design of astrocyte cultures and their culture with BMDM media. B) mRNA levels of genes associated with A1 and A2 astrocyte phenotypes in the presence of BMDM media by 
qPCR. C) mRNA levels of pro-inflammatory cytokine genes in the presence of BMDM media by qPCR. (B-C) Data normalized to M0 media activation. Results assessed for normality using the Shapiro-Wilk test and one-way ANOVA with Tukey post hoc test analyzed differences between conditions. * vs. control group (M0), \# M1 media vs. M2 media. 1 significant symbol p < $0.05,2$ significant symbol $\mathrm{p}<0.01$ and 3 significant symbol $\mathrm{p}<0.001$. Relative fold changes compared with the control group and presented as mean \pm SEM. ( $\mathrm{n}=3$ per group). D) mRNA levels of pro-inflammatory cytokine genes and genes associated with $\mathrm{A} 1$ and $\mathrm{A} 2$ astrocyte phenotypes in the presence of M1 media previously treated with or without CSPGs $(5 \mu \mathrm{g} / \mathrm{ml})$ determined by qPCR. E) mRNA levels of pro-inflammatory cytokine genes and genes associated with A1 and A2 astrocyte phenotypes in the presence of M2 media previously treated with or without CSPGs $(5 \mu \mathrm{g} / \mathrm{ml})$ determined by qPCR. (DE) Data normalized to BMDMs media previously treated without CSPGs (control group). Results assessed for normality using the Shapiro-Wilk test and analyzed using a two-tailed unpaired t-test. Data shown as mean \pm SEM. *p < $0.05, * * p<0.01$ vs. control group ( $n=3$ per group).

\subsubsection{TLR4 pathway is essential to develop the inflammatory phenotype on M2 BMDM}

Pharmacological inhibition of TLR4

While we understand the principal receptors through which CSPGs act (346), previous findings regarding the activation of inflammatory genes such as iNOS, COX2, and IL1b and the phosphorylation of p38/MAPK indicate that CSPGs may act through less studied receptors such as the TLRs. To investigate this possibility, we used a pharmacological inhibitor 
of TLR4 (TAK242) to block the TLR4 pathway in rat BMDMs (Figure 46, A).

In line with previous results, CSPGs treatment on proinflammatory derived (M1) BMDMs produced a slight but not significant reduction of inflammatory cytokine expression. Furthermore, we found that CSPG treatment of M1 BMDMs failed to impact the mRNA levels of inflammatory cytokines in TAK242 treated cells (Figure 46, B). On the other hand, as we expected, mRNA levels of IL1 $\beta$, CXCL10, CCL5, TNF $\alpha$, NFKB1a, and iNOS were significantly up-regulated after CSPGs treatment of M2-BMDMs (Figure 46, C). We observed that TLR4 signaling inhibition abolished this pro-inflammatory mRNA up-regulation by CSPGs in anti-inflammatory BMDMs reducing inflammatory cytokine gene expression to similar levels that control group and TAK242 (alone) conditions. Therefore, the block of the TLR4 pathway in M2 macrophages in vitro inactivate the pro-inflammatory effect exhibited by CSPGs in these cells. This finding suggests that CSPGs can act through the TLR4 pathways, causing increased pro-inflammatory cytokines in M2BMDM in vitro. 
A)

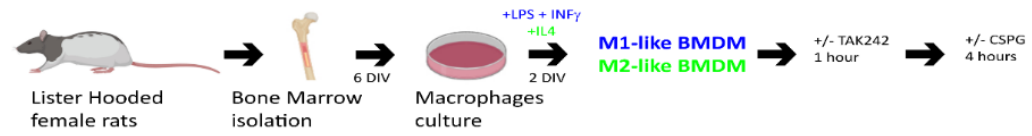

B)

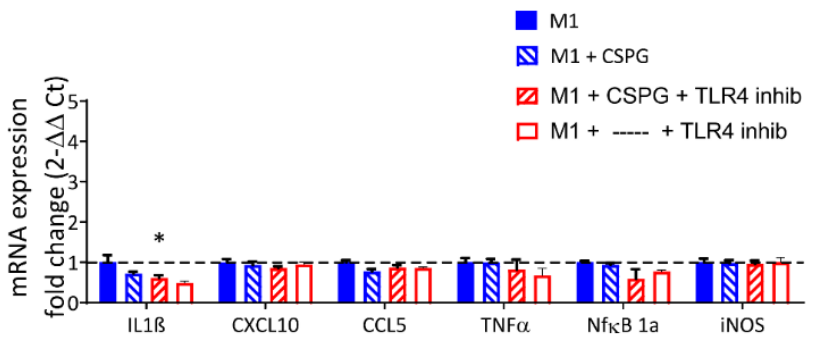

C)

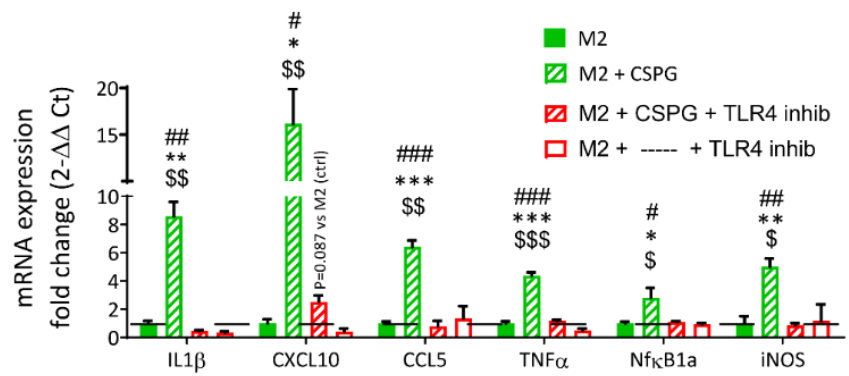

Figure 46. CSPG proinflammatory effects restored following TLR4

inhibition. A) Experimental design to study the effect of CSPG treatment (5 $\mathrm{ug} / \mathrm{ml}$ ) on polarized BMDMs treated with or without TAK242, a pharmacological inhibitor of TLR4. Bar graphs showing the expression of inflammatory response genes in B) M1 BMDMs and C) M2 BMDMs. mRNA levels determined by qPCR. Data normalized with respect to control (only M1 or M2). Results assessed for normality using the Shapiro-Wilk test and oneway ANOVA with Tukey post hoc test used to analyze differences between conditions. ${ }^{*} \mathrm{p}<0.05,{ }^{*} \mathrm{p}<0.01, * * * \mathrm{p}<0.001$ vs. control group, ${ }^{\#} \mathrm{p}<0.05$, ${ }^{\#} \mathrm{p}<0.01,{ }^{\# \#} \mathrm{p}<0.001$ vs + CSPGs+TLR4inhib group, ${ }^{\$} \mathrm{p}<0.01,{ }^{\$ \$} \mathrm{p}<0.001$, $\$ \$ p<0.001$ vs. - CSPGs+TLR4inhib group. Data presented as mean \pm SEM (n $=3$ per group). 
BMDMs from TLR4 ${ }^{-1-}$ mice have different proinflammatory profiles compared with BMDMs from WT mice

After ascertaining that TLR4 inhibition returns proinflammatory cytokines derived from the digestion of CSPGs in M2-BMDM to basal levels, we wanted to test the effect in macrophages derived from TLR4 deficient mice. For this purpose, we used BMDM culture from $\mathrm{WT}$ and $\mathrm{TLR} 4^{-/-}$mice following the same protocol used in rat BMDM (Figure 47, A).

Microscopy analysis exhibited differences in BMDMs morphology between WT and TLR $4^{-/-}$. Un-stimulated (M0) BMDM TLR4 $^{-/}$showed more elongated morphology than BMDMs from WT mice. While WT BMDMs exhibited a rounded morphology in M1 and an amoeboid morphology in M2, TLR4 ${ }^{-/-}$ BMDM did not show the same morphology pattern after polarization exhibiting both phenotypes an intermediate morphology between M1-WT and M2-WT, being more similar to M2 BMDM WT (Figure 47, B).

We corroborated the differences in BMDM polarization observed in morphology studies by the expression of iNOS (a well-known M1 marker) (354) by qPCR. Despite both BMDM WT and BMDM TLR4 ${ }^{-/}$exhibited more iNOS after inflammatory (M1) BMDM activation, we found lower iNOS expression in M1 BMDM TLR4 ${ }^{-/-}$than M1 BMDM WT (Figure 46, B left). In agreement with the qPCR results, Western blot 
analysis demonstrate the presence of iNOS protein expression in WT M1 BMDMs, suggesting the defective inflammatory activation of TLR $4^{-/-}$BMDMs (Figure 47, C).

Focusing on target genes differentially expressed in the previous experiments (CCL2, CCL5, COX2, CXCL10, IL1 $\beta$, IL10, TNF $\alpha$, and iNOS); we observed an increase in CCL2 and TNF $\alpha$ and a decrease in CCL5 and IL1 $\beta$ in M0 BMDM from $\mathrm{TLR}^{-/-}$mice compared to WT indicating the less inflammatory nature of TLR $4^{-/-}$-derived macrophages from the outset. In the M1 BMDM from $\mathrm{TLR}^{-{ }^{--}}$mice, we found the downregulation of proinflammatory genes (CCL2, CCL5, CXCL10, and IL1 $\beta$ ) compared to WT. Furthermore, the M2 BMDM from TLR $4^{-/-}$ mice have no differences (Figure 47, D). These results indicate that early TLR4 polarization affects macrophage differentiation (in M0) and that differentiation to a pro-inflammatory M1 phenotype depends on TLR4; however, polarization to an M2 phenotype does not depend on TLRs. 
Chapter 3: Results

A)

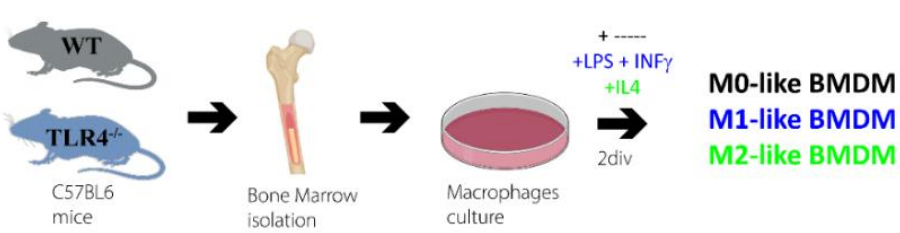

B)
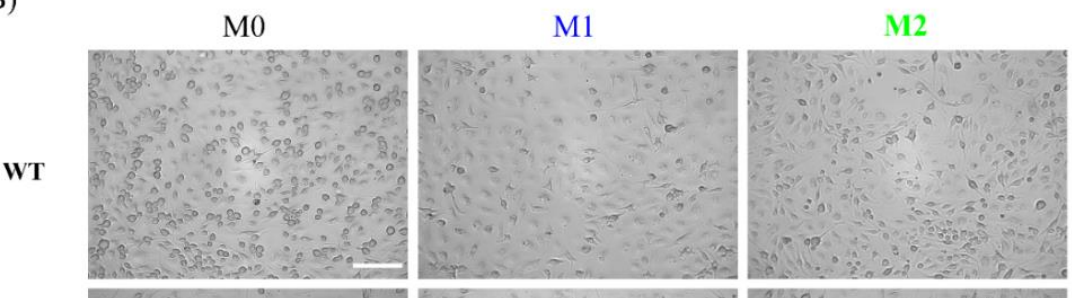

TLR4 $^{-1}$
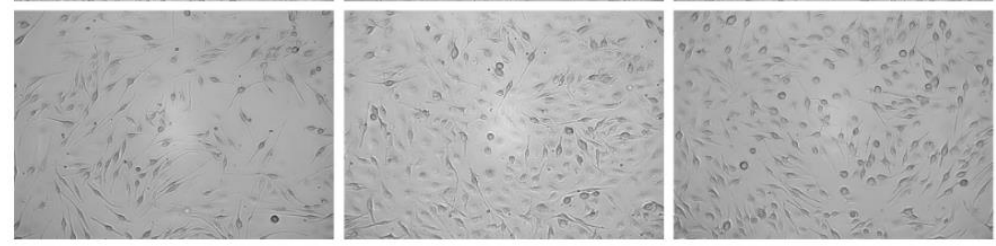

C)

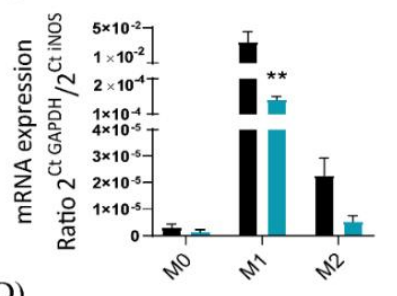

WT
TLR4

M1

M2

D)
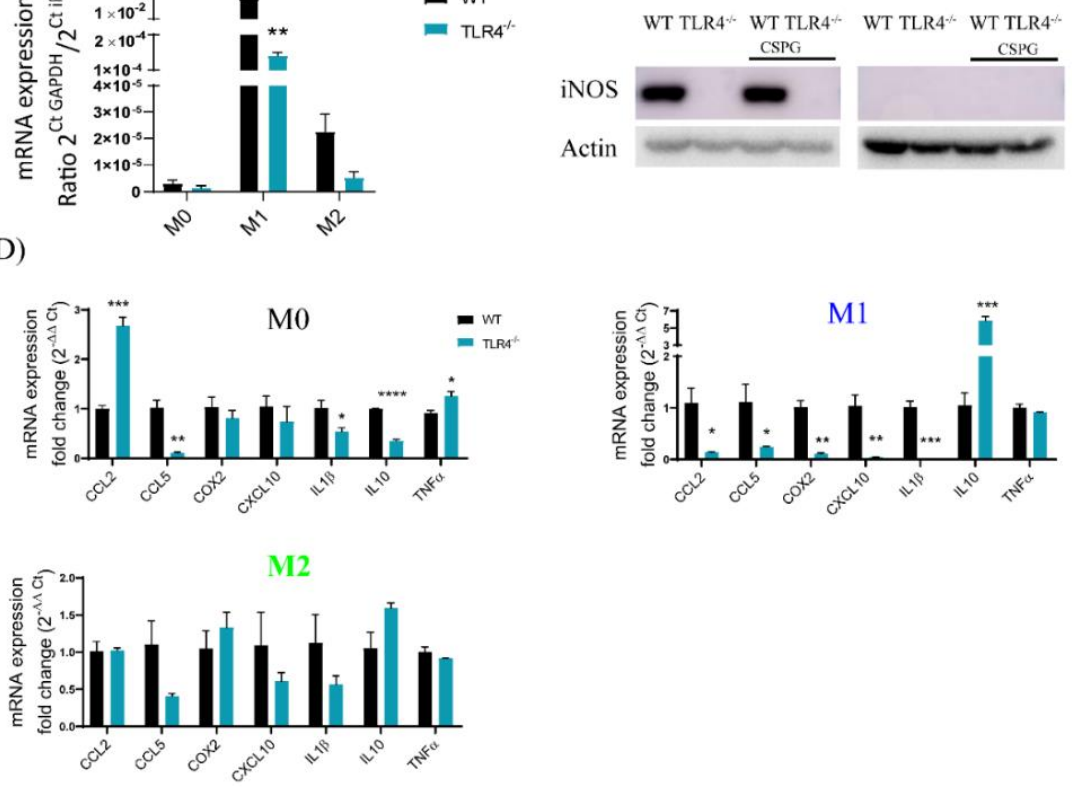

Figure 47. BMDM TLR4 ${ }^{-/-}$show less proinflammatory phenotype than BMDM from WT mice. A) Experimental design to study the effect of CSPG 
in BMDM from WT and TLR4 ${ }^{-/-}$mice. B) Images of bright field microscopy of BMDM from WT and BMDM from TRL4 ${ }^{-/}$showing morphology changes after M1 or M2 polarization. The scale bar corresponds to $100 \mu \mathrm{m}$. C) Bar graphs showing gene expression iNOS assessed by qPCR in M0, M1, and M2 polarized in WT and TLR4 ${ }^{-/}$BMDM. $* *$ p $<0.05$ WT vs TLR4 ${ }^{-/}$. Results assessed for normality using the Shapiro-Wilk test and one-way ANOVA with Tukey post hoc test analyzed significant differences. Data shown as mean \pm SEM ( $n=3$ per group). On the right, representative Western Blot band of iNOS protein in M1 and M2 BMDMs. D) Bar graphs showing gene expression in M0, M1, and M2 BMDM from WT and TLR4 ${ }^{-/}$mice. Results assessed for normality using the Shapiro-Wilk test and one-way ANOVA with Tukey post hoc test analyzed differences between conditions. Data shown as mean $\pm \mathrm{SEM}$ ( $\mathrm{n}=3$ per group). $* \mathrm{p}<0.05, * * \mathrm{p}<0.01, * * * \mathrm{p}<0.001, * * * * \mathrm{p}<0.0001$.

TLR4 pathway is essential to develop the inflammatory phenotype on $M 2$ BMDM by $C S P G$

Before investigating the effects of CSPGs in TLR4 ${ }^{-/}$ BMDMs, given the essential nature of TLR4 in immune cell activation, we assessed potential differences in BMDMs polarization by qPCR and western-blot in M1 and M2 polarized macrophages. Regarding M2, TLR4 deletion switched off the overexpression exhibited by CSPGs treatment in BMDM WT. In line with results obtained in rats, CSPGs treatment in M2 polarized macrophages from WT mice showed significant upregulation of CCL2, CCL3, CCL5, CXCL10, IL1 $\beta$, and TNF $\alpha$ (Figure 48, B) compared with their own control without CSPG (normalized to 1 in dotted line). However, M2 BMDM TLR4 ${ }^{-/-}$ only exhibited changes in CXCL10 cytokine expression after 
CSPGs treatment silenced all the other cytokine overexpression (Figure 48, B). We corroborated IL1 $\beta$ expression modulation by Western blot analysis where lack of TLR4 in BMDMs completely abolished the upregulation of IL1 $\beta$ in BMDM-TLR $4^{-/-}$after CSPG treatment compared with BMDM WT control group (Figure 48, D).

In summary, our data in M2 BMDMs strengthen the idea that TLR4 participates in the inflammatory activation of M2 BMDM exhibited by CSPGs. In line with all our previous data, CSPGs did not show significant differences in pro-inflammatory cytokine expression in BMDM WT. However, under defective M1 activated conditions, BMDM-TLR4 ${ }^{-/}$exhibited significant upregulation of CCL2, CXCL10, and IL1 $\beta$ after CSPGs treatment (Figure 48, A). Data suggests that on the contrary to naïve (M0) and M2 macrophages, where TLR4 prompts inflammatory activation, M1 macrophages are not fully activated (lack of TLR4) and CSPGs can enhances its inflammatory activation independent to TLR4 pathway.

Overall, our results indicate the essential nature of the TLR4 pathway for the development of the inflammatory phenotype of BMDM. In this line, our findings suggest that CSPGs can act through the TLR4 in inactivated (M0) macrophages or when macrophages try to adopt a more regenerative phenotype (M2), causing the switch to an inflammatory phenotype. 
A)

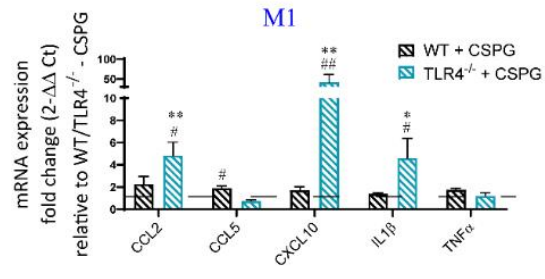

C)

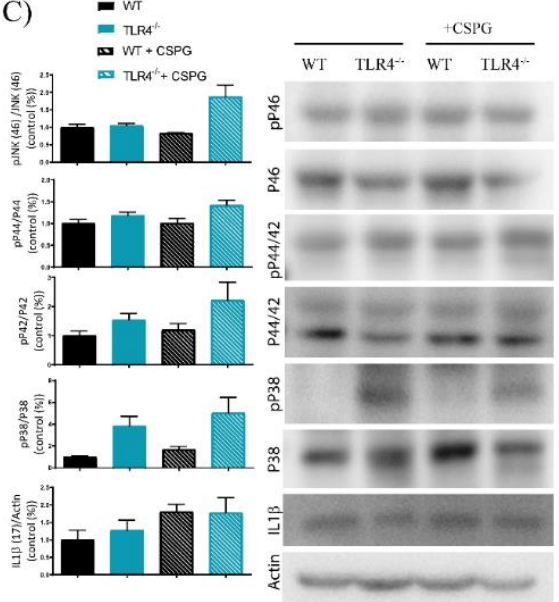

B)

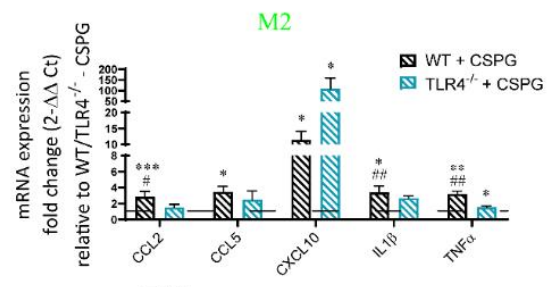

D)

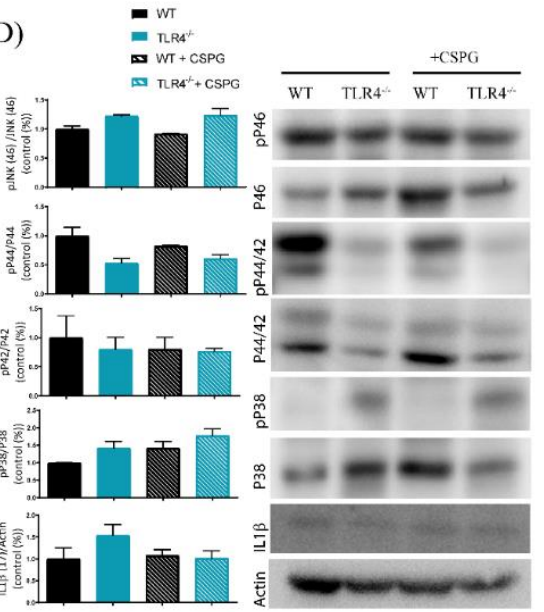

Figure 48. BMDM TLR4 ${ }^{-/-}$shows different response to CSPG treatment.

Bar graphs showing gene expression in M1 A) and M2 B) BMDM from WT and TLR4 ${ }^{-/-}$mice. Data were normalized with respect to own control group (no CSPG). Results were assessed for normality using the Shapiro-Wilk test and one-way ANOVA with Tukey post hoc test was used to analyse differences between conditions. Data are shown as mean \pm SEM ( $n=3$ per group). * significance vs WT and \# significance vs WT/TLR4 ${ }^{-/-}+$CSPGs. 1 significant symbol $\mathrm{p}<0.05,2$ significant symbol $\mathrm{p}<0.01$. Representative Western blots for M1 C) and M2 D) quantification analysis showing inflammatory intracellular pathway activation in WT and TLR4 $4^{-/}$BMDMs after $4 \mathrm{hr}$ CSPG treatment. Results were assessed for normality using the Shapiro-Wilk test and one-way ANOVA with Tukey post hoc test was used to analyse differences between conditions. Data are shown as mean \pm SEM ( $n=3$ per group). 


\subsection{Discussion}

CSPGs represent potent inhibitors of axonal growth and neuroplasticity after SCI (357). However, more recent studies have shown a pro-inflammatory effect on immune system cells involved in neuroinflammation following SCI (159). This chapter reports a role for CSPGs that goes far beyond growth inhibition and demonstrates their critical function as pro-inflammatory mediators for microglia and macrophages, and reveals that TLR4 drives CSPG immunomodulatory effects.

After injury or disease on CNS, neuroinflammation enables wound healing and tissue repair. However, the neuroinflammatory response supports the successful restoration of tissue homeostasis with a balance between beneficial and detrimental action. The failure of inflammation resolution can lead to impaired wound healing, chronic pathology, and neurodegeneration, typical pathological hallmarks of SCI in humans (358) and rodent models (359) . CSPGs have previously been implicated in neuroinflammation. CSPG regulate secondary injury mechanisms by LAR and PTPs receptor in the acute and subacute phase after injury (346). Previous results from the Bradbury lab focused on an in-depth characterization of the immunomodulatory role of CSPGs following SCI we delineate their effects on multiple cell types and cell phenotypes. We show that over-expression of the CSPG-digesting enzyme ChABC 
promotes immune cell clearance and pro-resolution phenotypic changes in both innate and adaptive immune cells and elicits dynamic immune signature changes in the tissue microenvironment at a key resolution time point (360). The previous finding of inhibition of CSPG immediately after acute spinal cord injury resulted in an alteration of the immune response, manifested by a significant loss of its compartmentalization (339) suggesting the role of CSPG in the motility and activation of macrophages (361) and other immune cell types (362).

To further understand the mechanisms behind CSPG immunomodulation we used BMDM and microglial cell cultures to evaluate the direct effects of CSPGS on innate immune cells. Recent studies have indicated that CSPGs can cause microglia to display proinflammatory properties, without adopting an M1 phenotype (346). Following stimulation of M2-polarized isolated microglia with CSPGs, we found a significant increase in classical M1-associated proinflammatory mediators (IL1 $\beta$, iNOS, $\mathrm{TNF} \alpha, \mathrm{CCL} 3)$ in both adult and neonatal cultures, indicating a direct influence of CSPGs in blocking M2 microglial conversion. Furthermore, in isolated BMDM from adult rats, we discovered an even more potent and specific phenotype-dependent effect of CSPG stimulation turned in a "pro-inflammatory phenotype". We found that CSPG stimulation has a negligible effect on already proinflammatory M1 polarized macrophages. These in vitro data 
provide evidence that the presence of CSPGs directly converts recruited monocyte/macrophages towards a M1 phenotype and hinders the transition to $\mathrm{M} 2$ at a tissue resolution level, resulting in a chronic inflammatory response. We report the importance of the crosstalk between the cells that form the fibrotic scar. Astrocytes are influenced by cytokines released by M1, increasing the expression levels of neuroprotective astrocyte (A1) (363). In addition, as with BMDMs, astrocytes with M2 macrophage activation, increase the levels of Il1 $\beta$, but also the expression of the neurotoxic astrocyte, A2 marker Serping 1 (363). Given the reciprocal activation of multiple cell types, such as astrocytes, by macrophages, this further underscores the role of CSPGs as potential central regulators of the neuroinflammatory response to injury.

Indeed, CSPG disaccharides have previously been shown to be neuroprotective against excitotoxic damage (364) and digested oligosaccharide products have been shown to influence TLR4 pathway activation in M1 macrophage-like cells(289) . In contrast to the limited effects of CSPG stimulation on proinflammatory M1 macrophages, and more meaningful in an inflammatory resolution context, we found that CSPG stimulation elicited potent effects on pro-resolving M2 polarized macrophages, where they acted to reverse the M2 phenotype to M1. TLRs recognize a wide variety of pathogen-associated molecular patterns, initiate acute inflammation through the 
production of inflammatory cytokines (39) and play a pivotal role as an amplifier of the inflammatory response in "sterile" conditions. TLR4 activation by endogenous ECM ligands has been explored in inflammation and tissue injury paradigms. TLR4 activation by endogenous molecules has been less studied in the context of CNS pathology, but its enhanced expression in microglial cells and peripheral macrophages in neurodegeneration models (365) make it a candidate to contribute to disease progression in the absence of pathogens. After SCI, the role of TLR4 and its endogenous ligands remains a complex affair, with most reports showing a detrimental inflammatory role of TLR4 activation (141) and improved recovery after TLR4 inhibition (366), although TLR4 inactivation can increase astrogliosis and lesion pathology (122). The role of CSPGs in TLR4 activation and its effect on the inflammatory response remains undescribed. Here, we provide novel data which links SCI upregulated CSPGs with TLR4 activation and detrimental consequences in chronic inflammatory responses. Using two approaches to inhibit TLR4 signaling (pharmacological inhibitors and a knockout model of TLR4), we show the requirement for TLR4 signaling for the CSPG-mediated phenotypic conversion of M0 and M2 macrophages towards a pro-inflammatory state. The significant upregulation of pro-inflammatory cytokines upon CSPG stimulation in M2 polarized BMDMs were consistently suppressed by TLR4 inhibition or deletion except for CXCL10 whose expression may be due to TLR3 upregulation which links 
its expression to TLR3 activity via IFN $(367,368)$. Our results suggest for the first time that SCI upregulated CSPGs can act through TLR4 signaling in inactivated (M0) macrophages or when macrophages try to adopt a more repair phenotype (M2), causing the switch to an inflammatory phenotype and delaying the resolution phase of inflammation with devastating consequences. 
CONCLUSIONS 


\section{CHAPTER1:}

1) TLR2 and TLR4 are co-expressed in the mouse neonatal spinal cord cells at similar mRNA and protein expression levels.

2) The absence of TLR 2 and TLR4 by ubiquitous deletion limits the expression of the cell population with nuclear SOX2 expression in spinal cords at the neonatal stage.

3) NPC derived from WT spinal cords co-express TLR2 and TLR4 with no differences in their gene and protein expression, and both respond to LPS stimulation activating their down-stream signalling pathways.

4) The absence of TLR2 significantly reduce the expression of TLR1 and TLR6, members of the TLR family to whom heterodimerizes.

5) The absence of TLR4 in NPC constitutively induces TLR9 expression.

6) The absence of TLR4 in NPC reduces the population with nuclear SOX2 expression, therefore, this receptor is relevant for the maintenance of this population in the neonate mouse spinal cord.

7) The absence of TLR2 induce self-renewal of NPC, therefore, this receptor is limiting the stemness in the neonatal mouse spinal cord.

8) TLR2 and TLR4 play a critical role for oligodendrocyte maturation of NPC from neonatal mouse spinal cord. The 
absence of any increases the expression of immature oligodendrocyte markers such as SOX10 and decreases the expression of the mature oligodendrocyte markers such as NG2.

9) TLR2 deficiency in neural progenitor cells arrests neural maturation while TLR4 deficiency prompts neural differentiation and astrocytic activation with an increase of Neurogenin1 and STAT3 expression.

\section{CHAPTER 2:}

1) The absence of TLR4 impairs locomotor recovery and enhanced neuronal degeneration after severe compressive SCI.

2) Transplantation of NPC improve neuronal preservation in the presence or absence of TLR 2 or TLR 4 receptors.

3) Transplantation after SCI of NPC lacking TLR2 limits motor recovery and induce larger lesion area in comparison with animals transplanted with naïve NPC.

4) Transplantation after SCI of NPC lacking TLR4 significantly improve functional locomotion in comparison with animals transplanted with NPC lacking TLR2. 


\section{CHAPTER 3:}

1) CSPGs, main component of fibrotic scar after spinal cord injury, can mediated the phenotypic conversion of BMDM from anti-inflammatory (M2) to proinflammatory (M1) through P38 phosphorylation.

2) Anti-inflammatory phenotype of microglia culture from neonatal and adult rats reverts to a pro-inflammatory phenotype upon CSPGs stimulation.

3) Metabolites derived from macrophage stimulation by CSPGs are able to modulate the gene expression of astrocyte phenotypic markers and cytokines in vitro.

4) Experiments using a pharmacological TLR4 inhibitor and TLR4-deficient mouse model show that inflammation produced by CSPGs in M2 BMDM is mediated by TLR4. 


\section{BIBLIOGRAPHICAL}

\section{REFERENCES}


1. Charles A Janeway J, Travers P, Walport M, Shlomchik MJ. Principles of innate and adaptive immunity. Immunobiology: The Immune System in Health and Disease 5th edition. 2001

2. Ginhoux F, Greter M, Leboeuf M, Nandi S, See P, Gokhan S, et al. Fate mapping analysis reveals that adult microglia derive from primitive macrophages. Science. 2010 Nov 5;330(6005):841-5.

3. Henneke P, Golenbock DT. Phagocytosis, Innate Immunity, and Host-Pathogen Specificity. J Exp Med. 2004 Jan 5;199(1):1-4.

4. Rus H, Cudrici C, Niculescu F. The role of the complement system in innate immunity. Immunol Res. 2005;33(2):103-12.

5. Lauvau G, Goriely S. Memory CD8+ T Cells: Orchestrators and Key Players of Innate Immunity? PLOS Pathogens. 2016 Sep 1;12(9):e1005722.

6. Vivier E, Tomasello E, Baratin M, Walzer T, Ugolini S. Functions of natural killer cells. Nature Immunology. 2008 May;9(5):50310.

7. Scott I. The role of mitochondria in the mammalian antiviral defense system. Mitochondrion. 2010 Jun;10(4):316-20.

8. Alberts B, Johnson A, Lewis J, Raff M, Roberts K, Walter P. Lymphocytes and the Cellular Basis of Adaptive Immunity. Molecular Biology of the Cell 4th edition. 2002

9. Chen GY, Nuñez G. Sterile inflammation: sensing and reacting to damage. Nat Rev Immunol. 2010 Dec;10(12):826-37.

10. Suresh $\mathrm{R}$, Mosser DM. Pattern recognition receptors in innate immunity, host defense, and immunopathology. Adv Physiol Educ. 2013 Dec;37(4):284-91.

11. Akira S, Takeda K, Kaisho T. Toll-like receptors: critical proteins linking innate and acquired immunity. Nat Immunol. 2001 Aug;2(8):675-80. 
12. Land WG. Injury to allografts: innate immune pathways to acute and chronic rejection. Saudi J Kidney Dis Transpl. 2005 Dec;16(4):520-39.

13. Janeway CA. Approaching the asymptote? Evolution and revolution in immunology. Cold Spring Harb Symp Quant Biol. 1989;54 Pt 1:1-13.

14. Medzhitov R. Origin and physiological roles of inflammation. Nature. 2008 Jul 24;454(7203):428-35.

15. Caruso R, Warner N, Inohara N, Núñez G. NOD1 and NOD2: Signaling, Host Defense, and Inflammatory Disease. Immunity. 2014 Dec 18;41(6):898-908.

16. Ting JP-Y, Williams KL. The CATERPILLER family: An ancient family of immune/apoptotic proteins. Clinical Immunology. 2005 Apr 1;115(1):33-7.

17. Hasegawa M, Fujimoto $Y$, Lucas $P C$, Nakano H, Fukase K, Núñez $G$, et al. A critical role of RICK/RIP2 polyubiquitination in Nodinduced NF-KB activation. The EMBO Journal. 2008 Jan 23;27(2):373-83.

18. Mahla RS, Reddy CM, Prasad D, Kumar H. Sweeten PAMPs: Role of sugar complexed PAMPs in innate immunity and vaccine biology. Front Immunol. 2013 Sep;4:248.

19. Saito T, Owen DM, Jiang F, Marcotrigiano J, Gale M. Innate immunity induced by composition-dependent RIG-I recognition of hepatitis C virus RNA. Nature. 2008 Jul;454(7203):523-7.

20. Feng Q, Hato SV, Langereis MA, Zoll J, Virgen-Slane R, Peisley A, et al. MDA5 Detects the Double-Stranded RNA Replicative Form in Picornavirus-Infected Cells. Cell Reports. 2012 Nov 29;2(5):1187-96.

21. Bruns AM, Leser GP, Lamb RA, Horvath $\mathrm{CM}$. The Innate Immune Sensor LGP2 Activates Antiviral Signaling by Regulating MDA5- 
RNA Interaction and Filament Assembly. Molecular Cell. 2014 Sep 4;55(5):771-81.

22. Taylor PR, Gordon S, Martinez-Pomares L. The mannose receptor: linking homeostasis and immunity through sugar recognition. Trends in Immunology. 2005 Feb 1;26(2):104-10.

23. Ip WKE, Takahashi K, Ezekowitz RA, Stuart LM. Mannosebinding lectin and innate immunity. Immunol Rev. 2009 Jul;230(1):9-21.

24. Takeda K, Akira S. TLR signaling pathways. Semin Immunol. 2004 Feb;16(1):3-9.

25. Anderson KV, Bokla L, Nüsslein-Volhard C. Establishment of dorsal-ventral polarity in the Drosophila embryo: the induction of polarity by the Toll gene product. Cell. 1985 Oct;42(3):7918.

26. Lemaitre B, Nicolas E, Michaut L, Reichhart JM, Hoffmann JA. The dorsoventral regulatory gene cassette spätzle/Toll/cactus controls the potent antifungal response in Drosophila adults. Cell. 1996 Sep 20;86(6):973-83.

27. The Nobel Prize in Physiology or Medicine 2011. NobelPrize.org. Nobel Prize Outreach AB 2021. Tue. $20 \mathrm{Jul}$ 2021. Available from: https://www.nobelprize.org/prizes/medicine/2011/summary/

28. Taguchi T, Mitcham JL, Dower SK, Sims JE, Testa JR. Chromosomal localization of TIL, a gene encoding a protein related to the Drosophila transmembrane receptor Toll, to human chromosome 4p14. Genomics. 1996 Mar 15;32(3):4868.

29. Medzhitov R, Preston-Hurlburt P, Janeway CA. A human homologue of the Drosophila Toll protein signals activation of adaptive immunity. Nature. 1997 Jul;388(6640):394-7. 
30. Botos I, Segal DM, Davies DR. The structural biology of Toll-like receptors. Structure. 2011 Apr 13;19(4):447-59.

31. Ve T, Gay NJ, Mansell A, Kobe B, Kellie S. Adaptors in toll-like receptor signaling and their potential as therapeutic targets. Curr Drug Targets. 2012 Oct;13(11):1360-74.

32. Rehli M. Of mice and men: species variations of Toll-like receptor expression. Trends Immunol. 2002 Aug;23(8):375-8.

33. Roh JS, Sohn DH. Damage-Associated Molecular Patterns in Inflammatory Diseases. Immune Netw. 2018 Aug 13;18(4):e27.

34. Kumar V. Toll-like receptors in the pathogenesis of neuroinflammation. J Neuroimmunol. 2019 Jul 15;332:16-30.

35. Sadeghalvad M, Mohammadi-Motlagh H-R, Rezaei N. Toll-Like Receptors. In: Reference Module in Biomedical Sciences. Elsevier; 2021

36. Gohda J, Matsumura T, Inoue J. Cutting Edge: TNFR-Associated Factor (TRAF) 6 Is Essential for MyD88-Dependent Pathway but Not Toll/IL-1 Receptor Domain-Containing Adaptor-Inducing IFN- $\beta$ (TRIF)-Dependent Pathway in TLR Signaling. The Journal of Immunology. 2004 Sep 1;173(5):2913-7.

37. Kawasaki T, Kawai T. Toll-Like Receptor Signaling Pathways. Front Immunol. 2014 Sep;5:461.

38. Pobezinskaya YL, Kim Y-S, Choksi S, Morgan MJ, Li T, Liu C, et al. The function of TRADD in signaling through tumor necrosis factor receptor 1 and TRIF-dependent Toll-like receptors. Nat Immunol. 2008 Sep;9(9):1047-54.

39. Kawai T, Akira S. The role of pattern-recognition receptors in innate immunity: update on Toll-like receptors. Nat Immunol. 2010 May;11(5):373-84. 
40. Zhu J, Mohan C. Toll-like receptor signaling pathways-therapeutic opportunities. Mediators Inflamm. 2010;2010:781235.

41. Cognasse F, Nguyen KA, Damien P, McNicol A, Pozzetto B, Hamzeh-Cognasse $\mathrm{H}$, et al. The Inflammatory Role of Platelets via Their TLRs and Siglec Receptors. Front Immunol. 2015 Mar 2;6:83.

42. Kim SJ, Kim HM. Dynamic lipopolysaccharide transfer cascade to TLR4/MD2 complex via LBP and CD14. BMB Rep. 2017;50(2):55-7.

43. Préhaud $C$, Mégret $F$, Lafage $M$, Lafon $M$. Virus Infection Switches TLR-3-Positive Human Neurons To Become Strong Producers of Beta Interferon. Journal of Virology. 2005 Oct 15;79(20):12893-904.

44. Cameron JS, Alexopoulou L, Sloane JA, DiBernardo AB, Ma Y, Kosaras $B$, et al. Toll-like receptor 3 is a potent negative regulator of axonal growth in mammals. J Neurosci. 2007 Nov 21;27(47):13033-41.

45. Wadachi R, Hargreaves KM. Trigeminal nociceptors express TLR-4 and CD14: a mechanism for pain due to infection. J Dent Res. 2006 Jan;85(1):49-53.

46. Ma Y, Li J, Chiu I, Wang Y, Sloane JA, Lü J, et al. Toll-like receptor 8 functions as a negative regulator of neurite outgrowth and inducer of neuronal apoptosis. J Cell Biol. 2006 Oct 23;175(2):209-15.

47. Li Y, Li H, Zhang Y, Sun X, Hanley GA, LeSage G, et al. Toll-like receptor 2 is required for opioids-induced neuronal apoptosis. Biochem Biophys Res Commun. 2010 Jan 1;391(1):426-30.

48. Tang S-C, Arumugam TV, Xu X, Cheng A, Mughal MR, Jo DG, et al. Pivotal role for neuronal Toll-like receptors in ischemic brain injury and functional deficits. Proc Natl Acad Sci U S A. 2007 Aug 21;104(34):13798-803. 
49. Kunda PE, Cavicchia JC, Acosta CG. Lipopolysaccharides and trophic factors regulate the LPS receptor complex in nodose and trigeminal neurons. Neuroscience. 2014 Nov 7;280:60-72.

50. Ochoa-Cortes F, Ramos-Lomas T, Miranda-Morales M, Spreadbury I, Ibeakanma C, Barajas-Lopez C, et al. Bacterial cell products signal to mouse colonic nociceptive dorsal root ganglia neurons. Am J Physiol Gastrointest Liver Physiol. 2010 Sep;299(3):G723-732.

51. Rietdijk CD, Wezel RJA van, Garssen J, Kraneveld AD. Neuronal toll-like receptors and neuro-immunity in Parkinson's disease, Alzheimer's disease and stroke. Neuroimmunology and Neuroinflammation. 2016 Feb 15;3:27-37.

52. Aguzzi A, Barres BA, Bennett ML. Microglia: scapegoat, saboteur, or something else? Science. 2013 Jan 11;339(6116):156-61.

53. Bsibsi M, Ravid R, Gveric D, van Noort JM. Broad Expression of Toll-Like Receptors in the Human Central Nervous System. Journal of Neuropathology \& Experimental Neurology. 2002 Nov 1;61(11):1013-21.

54. Olson JK, Miller SD. Microglia initiate central nervous system innate and adaptive immune responses through multiple TLRs. J Immunol. 2004 Sep 15;173(6):3916-24.

55. Cekanaviciute E, Buckwalter MS. Astrocytes: Integrative Regulators of Neuroinflammation in Stroke and Other Neurological Diseases. Neurotherapeutics. 2016 Oct;13(4):685-701.

56. McKimmie CS, Fazakerley JK. In response to pathogens, glial cells dynamically and differentially regulate Toll-like receptor gene expression. J Neuroimmunol. 2005 Dec;169(1-2):116-25.

57. Jack CS, Arbour N, Manusow J, Montgrain V, Blain M, McCrea E, et al. TLR signaling tailors innate immune responses in human 
microglia and astrocytes. J Immunol. 2005 Oct 1;175(7):432030.

58. Suh H-S, Zhao M-L, Choi N, Belbin TJ, Brosnan CF, Lee SC. TLR3 and TLR4 are innate antiviral immune receptors in human microglia: Role of IRF3 in modulating antiviral and inflammatory response in the CNS. Virology. 2009 Sep 30;392(2):246-59.

59. Frederiksen HR, Haukedal H, Freude K. Cell Type Specific Expression of Toll-Like Receptors in Human Brains and Implications in Alzheimer's Disease. BioMed Research International. 2019 Jul 18;2019:e7420189.

60. Cheng $C$, Qin $Y$, Shao $X$, Wang $H$, Gao $Y$, Cheng $M$, et al. Induction of TNF-alpha by LPS in Schwann cell is regulated by MAPK activation signals. Cell Mol Neurobiol. 2007 Nov;27(7):909-21.

61. Lee H, Jo E-K, Choi S-Y, Oh SB, Park K, Kim JS, et al. Necrotic neuronal cells induce inflammatory Schwann cell activation via TLR2 and TLR3: implication in Wallerian degeneration. Biochem Biophys Res Commun. 2006 Nov 24;350(3):742-7.

62. Oliveira RB, Ochoa MT, Sieling PA, Rea TH, Rambukkana A, Sarno EN, et al. Expression of Toll-like receptor 2 on human Schwann cells: a mechanism of nerve damage in leprosy. Infect Immun. 2003 Mar;71(3):1427-33.

63. Schonberg DL, Popovich PG, McTigue DM. Oligodendrocyte generation is differentially influenced by toll-like receptor (TLR) 2 and TLR4-mediated intraspinal macrophage activation. J Neuropathol Exp Neurol. 2007 Dec;66(12):1124-35.

64. Dromard C, Guillon H, Rigau V, Ripoll C, Sabourin JC, Perrin FE, et al. Adult human spinal cord harbors neural precursor cells that generate neurons and glial cells in vitro. J Neurosci Res. 2008 Jul;86(9):1916-26. 
65. Rolls A, Shechter R, London A, Ziv Y, Ronen A, Levy R, et al. Tolllike receptors modulate adult hippocampal neurogenesis. Nat Cell Biol. 2007 Sep;9(9):1081-8.

66. Paré AC, Vichas A, Fincher CT, Mirman Z, Farrell DL, Mainieri A, et al. A positional Toll receptor code directs convergent extension in Drosophila. Nature. 2014 Nov 27;515(7528):5237.

67. Foldi I, Anthoney N, Harrison N, Gangloff M, Verstak B, Nallasivan MP, et al. Three-tier regulation of cell number plasticity by neurotrophins and Tolls in Drosophila. J Cell Biol. 2017 May 1;216(5):1421-38.

68. Ward A, Hong W, Favaloro V, Luo L. Toll receptors instruct axon and dendrite targeting and participate in synaptic partner matching in a Drosophila olfactory circuit. Neuron. 2015 Mar 4;85(5):1013-28.

69. Anthoney N, Foldi I, Hidalgo A. Toll and Toll-like receptor signalling in development. Development. 2018 Apr 25;145(9).

70. Stathopoulos A, Levine M. Dorsal gradient networks in the Drosophila embryo. Dev Biol. 2002 Jun 1;246(1):57-67.

71. Meyer SN, Amoyel M, Bergantiños C, de la Cova C, Schertel C, Basler K, et al. An ancient defense system eliminates unfit cells from developing tissues during cell competition. Science. 2014 Dec 5;346(6214):1258236.

72. Ballard SL, Miller DL, Ganetzky B. Retrograde neurotrophin signaling through Tollo regulates synaptic growth in Drosophila. J Cell Biol. 2014 Mar 31;204(7):1157-72.

73. McLaughlin CN, Nechipurenko IV, Liu N, Broihier HT. A Toll receptor-FoxO pathway represses Pavarotti/MKLP1 to promote microtubule dynamics in motoneurons. J Cell Biol. 2016 Aug 15;214(4):459-74. 
74. Brandt JP, Ringstad N. Toll-like Receptor Signaling Promotes Development and Function of Sensory Neurons Required for a C. elegans Pathogen-Avoidance Behavior. Current Biology. 2015 Aug 31;25(17):2228-37.

75. Irazoqui JE, Ng A, Xavier RJ, Ausubel FM. Role for beta-catenin and HOX transcription factors in Caenorhabditis elegans and mammalian host epithelial-pathogen interactions. Proc Natl Acad Sci U S A. 2008 Nov 11;105(45):17469-74.

76. Chuang $\mathrm{C}-\mathrm{F}$, Bargmann $\mathrm{Cl}$. A Toll-interleukin 1 repeat protein at the synapse specifies asymmetric odorant receptor expression via ASK1 MAPKKK signaling. Genes Dev. 2005 Jan 15;19(2):27081.

77. Sloane JA, Batt C, Ma Y, Harris ZM, Trapp B, Vartanian T. Hyaluronan blocks oligodendrocyte progenitor maturation and remyelination through TLR2. Proc Natl Acad Sci U S A. 2010 Jun 22;107(25):11555-60.

78. Okun E, Griffioen KJ, Son TG, Lee J-H, Roberts NJ, Mughal MR, et al. TLR2 activation inhibits embryonic neural progenitor cell proliferation. J Neurochem. 2010 Jul;114(2):462-74.

79. Shechter R, Ronen A, Rolls A, London A, Bakalash S, Young MJ, et al. Toll-like receptor 4 restricts retinal progenitor cell proliferation. J Cell Biol. 2008 Nov 3;183(3):393-400.

80. Grasselli C, Ferrari D, Zalfa C, Soncini M, Mazzoccoli G, Facchini $F A$, et al. Toll-like receptor 4 modulation influences human neural stem cell proliferation and differentiation. Cell Death \& Disease. 2018 Feb 15;9(3):1-15.

81. Lathia JD, Okun E, Tang S-C, Griffioen K, Cheng A, Mughal MR, et al. Toll-Like Receptor 3 Is a Negative Regulator of Embryonic Neural Progenitor Cell Proliferation. Journal of Neuroscience. 2008 Dec 17;28(51):13978-84.

82. Okun E, Griffioen K, Barak B, Roberts NJ, Castro K, Pita MA, et al. Toll-like receptor 3 inhibits memory retention and constrains 
adult hippocampal neurogenesis. Proc Natl Acad Sci U S A. 2010 Aug 31;107(35):15625-30.

83. Ma Y, Haynes RL, Sidman RL, Vartanian T. TLR8: an innate immune receptor in brain, neurons and axons. Cell Cycle. 2007 Dec 1;6(23):2859-68.

84. de Oliveira ACP, Yousif NM, Bhatia HS, Hermanek J, Huell M, Fiebich BL. Poly $(\mathrm{I}: \mathrm{C})$ increases the expression of mPGES-1 and COX-2 in rat primary microglia. Journal of Neuroinflammation. $2016 \operatorname{Jan} 18 ; 13(1): 11$.

85. Walker DG, Tang TM, Lue L-F. Increased expression of toll-like receptor 3, an anti-viral signaling molecule, and related genes in Alzheimer's disease brains. Exp Neurol. 2018 Nov;309:91106.

86. Brea $\mathrm{D}$, Sobrino $\mathrm{T}$, Rodríguez-Yáñez $\mathrm{M}$, Ramos-Cabrer $\mathrm{P}$, Agulla $\mathrm{J}$, Rodríguez-González $\mathrm{R}$, et al. Toll-like receptors 7 and 8 expression is associated with poor outcome and greater inflammatory response in acute ischemic stroke. Clin Immunol. 2011 May;139(2):193-8.

87. Tang S-C, Yeh S-J, Li Y-I, Wang Y-C, Baik S-H, Santro T, et al. Evidence for a detrimental role of TLR8 in ischemic stroke. Exp Neurol. 2013 Dec;250:341-7.

88. van Noort JM, Bsibsi M. Toll-like receptors in the CNS: implications for neurodegeneration and repair. Prog Brain Res. 2009;175:139-48.

89. Brudek T, Winge K, Agander TK, Pakkenberg B. Screening of Toll-like receptors expression in multiple system atrophy brains. Neurochem Res. 2013 Jun;38(6):1252-9.

90. Letiembre M, Liu Y, Walter S, Hao W, Pfander T, Wrede A, et al. Screening of innate immune receptors in neurodegenerative diseases: a similar pattern. Neurobiol Aging. 2009 May;30(5):759-68. 
91. Liu H, Hung $\mathrm{Y}$, Lin $\mathrm{H}$, Yen $\mathrm{T}$, Hsueh $\mathrm{Y}$. TIr7 Deletion Selectively Ameliorates Spatial Learning but does not Influence beta Deposition and Inflammatory Response in an Alzheimers Disease Mouse Model. Neuropsychiatry. 2017 Jan 1;07.

92. Ros-Bernal F, Hunot S, Herrero MT, Parnadeau S, Corvol J-C, Lu $L$, et al. Microglial glucocorticoid receptors play a pivotal role in regulating dopaminergic neurodegeneration in parkinsonism. Proc Natl Acad Sci U S A. 2011 Apr 19;108(16):6632-7.

93. Dalpke AH, Schäfer MK-H, Frey M, Zimmermann S, Tebbe J, Weihe $\mathrm{E}$, et al. Immunostimulatory CpG-DNA activates murine microglia. J Immunol. 2002 May 15;168(10):4854-63.

94. Iliev Al, Stringaris AK, Nau R, Neumann H. Neuronal injury mediated via stimulation of microglial toll-like receptor-9 (TLR9). FASEB J. 2004 Feb;18(2):412-4.

95. Tauber SC, Ebert S, Weishaupt JH, Reich A, Nau R, Gerber J. Stimulation of Toll-like receptor 9 by chronic intraventricular unmethylated cytosine-guanine DNA infusion causes neuroinflammation and impaired spatial memory. J Neuropathol Exp Neurol. 2009 Oct;68(10):1116-24.

96. Rosenberger K, Derkow K, Dembny P, Krüger C, Schott E, Lehnardt $\mathrm{S}$. The impact of single and pairwise Toll-like receptor activation on neuroinflammation and neurodegeneration. J Neuroinflammation. 2014 Sep 20;11:166.

97. Guillot-Sestier M-V, Town T. Let's make microglia great again in neurodegenerative disorders. J Neural Transm (Vienna). 2018 May;125(5):751-70.

98. Gong T, Liu L, Jiang W, Zhou R. DAMP-sensing receptors in sterile inflammation and inflammatory diseases. Nat Rev Immunol. 2020 Feb;20(2):95-112.

99. Xiang Z, Chen M, Ping J, Dunn P, Lv J, Jiao B, et al. Microglial morphology and its transformation after challenge by 
extracellular ATP in vitro. J Neurosci Res. 2006 Jan;83(1):91101.

100. McDonald CL, Hennessy E, Rubio-Araiz A, Keogh B, McCormack W, McGuirk $P$, et al. Inhibiting TLR2 activation attenuates amyloid accumulation and glial activation in a mouse model of Alzheimer's disease. Brain, Behavior, and Immunity. 2016 Nov 1;58:191-200.

101. Lin $W$, Ding $M$, Xue J, Leng $W$. The role of TLR2/JNK/NF-KB pathway in amyloid $\beta$ peptide-induced inflammatory response in mouse NG108-15 neural cells. Int Immunopharmacol. 2013 Nov;17(3):880-4.

102. Tang S-C, Lathia JD, Selvaraj PK, Jo D-G, Mughal MR, Cheng A, et al. Toll-like receptor-4 mediates neuronal apoptosis induced by amyloid beta-peptide and the membrane lipid peroxidation product 4-hydroxynonenal. Exp Neurol. 2008 Sep;213(1):11421.

103. Song M, Jin J, Lim J-E, Kou J, Pattanayak A, Rehman JA, et al. TLR4 mutation reduces microglial activation, increases $A \beta$ deposits and exacerbates cognitive deficits in a mouse model of Alzheimer's disease. J Neuroinflammation. 2011 Aug 9;8:92.

104. Qin Y, Liu Y, Hao W, Decker Y, Tomic I, Menger MD, et al. Stimulation of TLR4 Attenuates Alzheimer's Disease-Related Symptoms and Pathology in Tau-Transgenic Mice. J Immunol. 2016 Oct 15;197(8):3281-92.

105. Lotz M, Ebert S, Esselmann H, lliev Al, Prinz M, Wiazewicz N, et al. Amyloid beta peptide 1-40 enhances the action of Toll-like receptor-2 and -4 agonists but antagonizes Toll-like receptor-9induced inflammation in primary mouse microglial cell cultures. Journal of Neurochemistry. 2005;94(2):289-98.

106. Reed-Geaghan EG, Savage JC, Hise AG, Landreth GE. CD14 and Toll-Like Receptors 2 and 4 Are Required for Fibrillar $A \beta$ Stimulated Microglial Activation. J Neurosci. 2009 Sep 23;29(38):11982-92. 
107. Drouin-Ouellet J, St-Amour I, Saint-Pierre M, LamontagneProulx J, Kriz J, Barker RA, et al. Toll-Like Receptor Expression in the Blood and Brain of Patients and a Mouse Model of Parkinson's Disease. Int J Neuropsychopharmacol [Internet]. 2015 Mar 5 [cited 2021 Apr 26];18(6). Available from: https://www.ncbi.nlm.nih.gov/pmc/articles/PMC4438545/

108. Kim C, Lee H-J, Masliah E, Lee S-J. Non-cell-autonomous Neurotoxicity of $\alpha$-synuclein Through Microglial Toll-like Receptor 2. Exp Neurobiol. 2016 Jun;25(3):113-9.

109. Fellner L, Irschick R, Schanda K, Reindl M, Klimaschewski L, Poewe $W$, et al. Toll-like receptor 4 is required for $\alpha$-synuclein dependent activation of microglia and astroglia. Glia. 2013 Mar;61(3):349-60.

110. Stefanova N, Fellner L, Reindl M, Masliah E, Poewe W, Wenning GK. Toll-like receptor 4 promotes $\alpha$-synuclein clearance and survival of nigral dopaminergic neurons. Am J Pathol. 2011 Aug;179(2):954-63.

111. Casula M, Iyer AM, Spliet WGM, Anink JJ, Steentjes K, Sta M, et al. Toll-like receptor signaling in amyotrophic lateral sclerosis spinal cord tissue. Neuroscience. 2011 Apr 14;179:233-43.

112. Paola MD, Mariani A, Bigini P, Peviani M, Ferrara G, Molteni M, et al. Neuroprotective Effects of Toll-Like Receptor 4 Antagonism in Spinal Cord Cultures and in a Mouse Model of Motor Neuron Degeneration. Mol Med. 2012 Jun;18(6):97181.

113. Li H-Y, Yuan Z-Y, Wang Y-G, Wan H-J, Hu J, Chai Y-S, et al. Role of baicalin in regulating Toll-like receptor $2 / 4$ after ischemic neuronal injury. Chin Med J (Engl). 2012 May;125(9):1586-93.

114. Donnelly CR, Chen O, Ji R-R. How Do Sensory Neurons Sense Danger Signals? Trends in Neurosciences. 2020 Oct 1;43(10):822-38 . 
115. Struve J, Maher PC, Li Y-Q, Kinney S, Fehlings MG, Kuntz C, et al. Disruption of the hyaluronan-based extracellular matrix in spinal cord promotes astrocyte proliferation. Glia. 2005 Oct;52(1):16-24.

116. Schaefer L, lozzo RV. Biological Functions of the Small Leucinerich Proteoglycans: From Genetics to Signal Transduction *. Journal of Biological Chemistry. 2008 Aug 1;283(31):21305-9.

117. Kim S, Takahashi H, Lin W-W, Descargues P, Grivennikov S, Kim $\mathrm{Y}$, et al. Carcinoma-produced factors activate myeloid cells through TLR2 to stimulate metastasis. Nature. 2009 Jan 1;457(7225):102-6.

118. Goh FG, Piccinini AM, Krausgruber T, Udalova IA, Midwood KS. Transcriptional regulation of the endogenous danger signal tenascin-C: a novel autocrine loop in inflammation. J Immunol. 2010 Mar 1;184(5):2655-62.

119. Satake $K$, Matsuyama $Y$, Kamiya $M$, Kawakami $H$, Iwata $H$, Adachi $\mathrm{K}$, et al. Up-regulation of glial cell line-derived neurotrophic factor (GDNF) following traumatic spinal cord injury. Neuroreport. 2000 Nov 27;11(17):3877-81.

120. Nesic O, Xu GY, McAdoo D, High KW, Hulsebosch C, Perez-Pol R. IL-1 receptor antagonist prevents apoptosis and caspase-3 activation after spinal cord injury. J Neurotrauma. 2001 Sep;18(9):947-56.

121. Bethea JR, Castro M, Keane RW, Lee TT, Dietrich WD, Yezierski RP. Traumatic spinal cord injury induces nuclear factor-kappaB activation. J Neurosci. 1998 May 1;18(9):3251-60.

122. Kigerl KA, Lai W, Rivest S, Hart RP, Satoskar AR, Popovich PG. Toll-like receptor (TLR)-2 and TLR-4 regulate inflammation, gliosis, and myelin sparing after spinal cord injury. J Neurochem. 2007 Jul;102(1):37-50.

123. Adhikary S, Li H, Heller J, Skarica M, Zhang M, Ganea D, et al. Modulation of inflammatory responses by a cannabinoid-2- 
selective agonist after spinal cord injury. J Neurotrauma. 2011 Dec;28(12):2417-27.

124. Chamankhah $\mathrm{M}$, Eftekkharpour E, Karimi-Abdolrezaee $\mathrm{S}$, Boutros P, San-Marina S, Fehlings M. Genome-wide gene expression profiling of stress response in a spinal cord clip compression injury model. BMC genomics. 2013 Aug 28;14:583.

125. Stirling D, Cummins K, Mishra M, Teo W, Yong VW, Stys P. Tolllike receptor 2-mediated alternative activation of microglia is protective after spinal cord injury. Brain: a journal of neurology. 2013 Dec 24;137.

126. Wang $\mathrm{P}-\mathrm{F}$, Fang $\mathrm{H}$, Chen $\mathrm{J}$, Lin $\mathrm{S}$, Liu $\mathrm{Y}$, Xiong $\mathrm{X}-\mathrm{Y}$, et al. Polyinosinic-Polycytidylic Acid Has Therapeutic Effects against Cerebral Ischemia/Reperfusion Injury through the Downregulation of TLR4 Signaling via TLR3. J Immunol. 2014 May 15;192(10):4783-94.

127. Lobenwein D, Tepeköylü C, Kozaryn R, Pechriggl EJ, Bitsche M, Graber $M$, et al. Shock Wave Treatment Protects From Neuronal Degeneration via a Toll-Like Receptor 3 Dependent Mechanism: Implications of a First-Ever Causal Treatment for Ischemic Spinal Cord Injury. J Am Heart Assoc. 2015 Oct 27;4(10):e002440.

128. Huang H, Evankovich J, Yan W, Nace G, Zhang L, Ross M, et al. Endogenous histones function as alarmins in sterile inflammatory liver injury through Toll-like receptor 9 in mice. Hepatology. 2011 Sep 2;54(3):999-1008.

129. David BT, Ratnayake A, Amarante MA, Reddy NP, Dong W, Sampath S, et al. A toll-like receptor 9 antagonist reduces pain hypersensitivity and the inflammatory response in spinal cord injury. Neurobiol Dis. 2013 Jun;54:194-205.

130. David BT, Sampath S, Dong W, Heiman A, Rella CE, Elkabes S, et al. A toll-like receptor 9 antagonist improves bladder function and white matter sparing in spinal cord injury. J Neurotrauma. 2014 Nov 1;31(21):1800-6. 
131. Shechter R, London A, Varol C, Raposo C, Cusimano M, Yovel G, et al. Infiltrating blood-derived macrophages are vital cells playing an anti-inflammatory role in recovery from spinal cord injury in mice. PLoS Med. 2009 Jul;6(7):e1000113.

132. Yao A-H, Jia L-Y, Zhang Y-K, Ma Q-R, Cheng P, Liu L, et al. Early Blockade of TLRs MyD88-Dependent Pathway May Reduce Secondary Spinal Cord Injury in the Rats. Evid Based Complement Alternat Med. 2012;2012:591298.

133. Ni H, Jin $\mathrm{W}$, Zhu T, Wang J, Yuan B, Jiang J, et al. Curcumin modulates TLR4/NF-KB inflammatory signaling pathway following traumatic spinal cord injury in rats. J Spinal Cord Med. 2015 Mar;38(2):199-206.

134. Lehnardt S. Innate immunity and neuroinflammation in the CNS: the role of microglia in Toll-like receptor-mediated neuronal injury. Glia. $2010 \mathrm{Feb}$;58(3):253-63.

135. Pais TF, Figueiredo C, Peixoto R, Braz MH, Chatterjee S. Necrotic neurons enhance microglial neurotoxicity through induction of glutaminase by a MyD88-dependent pathway. J Neuroinflammation. 2008 Oct 9;5:43.

136. Zhang $\mathrm{Y}-\mathrm{K}$, Liu J-T, Peng Z-W, Fan $\mathrm{H}$, Yao A-H, Cheng P, et al. Different TLR4 expression and microglia/macrophage activation induced by hemorrhage in the rat spinal cord after compressive injury. Journal of Neuroinflammation. 2013 Sep 10;10(1):881.

137. Impellizzeri D, Ahmad A, Di Paola R, Campolo M, Navarra M, Esposito $\mathrm{E}$, et al. Role of Toll like receptor 4 signaling pathway in the secondary damage induced by experimental spinal cord injury. Immunobiology. 2015 Sep;220(9):1039-49.

138. Kigerl KA, Popovich PG. Toll-like receptors in spinal cord injury. Curr Top Microbiol Immunol. 2009;336:121-36.

139. Hesp ZC, Goldstein EZ, Goldstein EA, Miranda CJ, Kaspar BK, Kaspar BK, et al. Chronic oligodendrogenesis and remyelination 
after spinal cord injury in mice and rats. J Neurosci. 2015 Jan 21;35(3):1274-90.

140. Schonberg DL, McTigue DM. Iron is essential for oligodendrocyte genesis following intraspinal macrophage activation. Exp Neurol. 2009 Jul;218(1):64-74.

141. Church JS, Kigerl KA, Lerch JK, Popovich PG, McTigue DM. TLR4 Deficiency Impairs Oligodendrocyte Formation in the Injured Spinal Cord. J Neurosci. 2016 Jun 8;36(23):6352-64.

142. Burns AS, O'Connell C. The challenge of spinal cord injury care in the developing world. J Spinal Cord Med. 2012 Jan;35(1):38.

143. Thuret S, Moon LDF, Gage FH. Therapeutic interventions after spinal cord injury. Nat Rev Neurosci. 2006 Aug;7(8):628-43.

144. National Spinal Cord Injury Statistical Center, Facts and Figures at a Glance. Birmingham, AL: University of Alabama at Birmingham, 2020.

145. Ge L, Arul K, Ikpeze T, Baldwin A, Nickels JL, Mesfin A. Traumatic and Nontraumatic Spinal Cord Injuries. World Neurosurg. 2018 Mar;111:e142-8.

146. Cramer SC, Lastra L, Lacourse MG, Cohen MJ. Brain motor system function after chronic, complete spinal cord injury. Brain. 2005 Dec;128(Pt 12):2941-50.

147. Oyinbo CA. Secondary injury mechanisms in traumatic spinal cord injury: a nugget of this multiply cascade. Acta Neurobiol Exp (Wars). 2011;71(2):281-99.

148. Silva NA, Sousa N, Reis RL, Salgado AJ. From basics to clinical: a comprehensive review on spinal cord injury. Prog Neurobiol. 2014 Mar;114:25-57.

149. Balentine JD, Spector M. Calcification of axons in experimental spinal cord trauma. Ann Neurol. 1977 Dec;2(6):520-3. 
150. Lotan M, Solomon A, Ben-Bassat S, Schwartz M. Cytokines Modulate the Inflammatory Response and Change Permissiveness to Neuronal Adhesion in Injured Mammalian Central Nervous System. Experimental Neurology. 1994 Apr 1;126(2):284-90.

151. Tator $\mathrm{CH}$, Fehlings MG. Review of the secondary injury theory of acute spinal cord trauma with emphasis on vascular mechanisms. J Neurosurg. 1991 Jul;75(1):15-26.

152. Franzen R, Schoenen J, Leprince P, Joosten E, Moonen G, Martin D. Effects of macrophage transplantation in the injured adult rat spinal cord: a combined immunocytochemical and biochemical study. J Neurosci Res. 1998 Feb 1;51(3):316-27.

153. Papastefanaki F, Matsas R. From demyelination to remyelination: the road toward therapies for spinal cord injury. Glia. 2015 Jul;63(7):1101-25.

154. David S, Lacroix S. Molecular approaches to spinal cord repair. Annual review of neuroscience. 2003 Feb 1;26:411-40.

155. Guest J, Harrop JS, Aarabi B, Grossman RG, Fawcett JW, Fehlings $M G$, et al. Optimization of the decision-making process for the selection of therapeutics to undergo clinical testing for spinal cord injury in the North American Clinical Trials Network. J Neurosurg Spine. 2012 Sep;17(1 Suppl):94-101.

156. Thiede-Stan NK, Tews B, Albrecht D, Ristic Z, Ewers H, Schwab ME. Tetraspanin-3 is an organizer of the multi-subunit Nogo-A signaling complex. Journal of Cell Science. 2015 Oct 1;128(19):3583-96.

157. Siebert JR, Conta Steencken A, Osterhout DJ. Chondroitin sulfate proteoglycans in the nervous system: inhibitors to repair. Biomed Res Int. 2014;2014:845323.

158. Sofroniew MV. Astrocyte barriers to neurotoxic inflammation. Nat Rev Neurosci. 2015 May;16(5):249-63. 
159. Bradbury EJ, Burnside ER. Moving beyond the glial scar for spinal cord repair. Nat Commun. 2019 Aug 28;10(1):3879.

160. Gaudet AD, Popovich PG, Ramer MS. Wallerian degeneration: gaining perspective on inflammatory events after peripheral nerve injury. J Neuroinflammation. 2011 Aug 30;8:110.

161. Hoogenes B, Querée M, Miller WC, Mortenson WB, Townson A, Eng JJ. Evidence on definitions, concepts, outcome instruments, and interventions for chronic fatigue in spinal cord injury: a scoping review protocol. JBI Evid Synth. 2021 Apr 12;

162. Assinck P, Duncan GJ, Hilton BJ, Plemel JR, Tetzlaff W. Cell transplantation therapy for spinal cord injury. Nature Neuroscience. 2017 May;20(5):637-47.

163. Axonal Elongation into Peripheral Nervous System "Bridges" after Central Nervous System Injury in Adult Rats on JSTOR [Internet]. [cited 2021 Apr 25]. Available from: https://www.jstor.org/stable/1686337?seq=1

164. Eng LF, Reier PJ, Houle JD. Astrocyte activation and fibrous gliosis: glial fibrillary acidic protein immunostaining of astrocytes following intraspinal cord grafting of fetal CNS tissue. Prog Brain Res. 1987;71:439-55.

165. Curtis E, Martin JR, Gabel B, Sidhu N, Rzesiewicz TK, Mandeville $R$, et al. A First-in-Human, Phase I Study of Neural Stem Cell Transplantation for Chronic Spinal Cord Injury. Cell Stem Cell. 2018 Jun 1;22(6):941-950.e6.

166. Zhang $G$, Cunningham $M$, Zhang $H$, Dai $Y$, Zhang $P$, Ge G, et al. First Human Trial of Stem Cell Transplantation in Complex Arrays for Stroke Patients Using the Intracerebral Microinjection Instrument. Oper Neurosurg (Hagerstown). 2020 May 1;18(5):503-10.

167. Zhang G, Li Y, Reuss JL, Liu N, Wu C, Li J, et al. Stable Intracerebral Transplantation of Neural Stem Cells for the 
Treatment of Paralysis Due to Ischemic Stroke. Stem Cells Transl Med. 2019 Oct;8(10):999-1007.

168. Levi AD, Anderson KD, Okonkwo DO, Park P, Bryce TN, Kurpad $\mathrm{SN}$, et al. Clinical Outcomes from a Multi-Center Study of Human Neural Stem Cell Transplantation in Chronic Cervical Spinal Cord Injury. J Neurotrauma. 2019 Mar 19;36(6):891-902.

169. Levi AD, Okonkwo DO, Park P, Jenkins AL, Kurpad SN, Parr AM, et al. Emerging Safety of Intramedullary Transplantation of Human Neural Stem Cells in Chronic Cervical and Thoracic Spinal Cord Injury. Neurosurgery. 2018 Apr 1;82(4):562-75.

170. Cyranoski D. 'Reprogrammed' stem cells to treat spinal-cord injuries for the first time. Nature. 2019 Mar 3;

171. Tanimoto $\mathrm{Y}$, Yamasaki T, Nagoshi N, Nishiyama $\mathrm{Y}$, Nori S, Nishimura $S$, et al. In vivo monitoring of remnant undifferentiated neural cells following human induced pluripotent stem cell-derived neural stem/progenitor cells transplantation. Stem Cells Transl Med. 2020;9(4):465-77.

172. Kajikawa K, Imaizumi K, Shinozaki M, Shibata S, Shindo T, Kitagawa $T$, et al. Cell therapy for spinal cord injury by using human iPSC-derived region-specific neural progenitor cells. Mol Brain. 2020;13(1):120.

173. Iwai H, Shimada H, Nishimura S, Kobayashi Y, Itakura G, Hori K, et al. Allogeneic Neural Stem/Progenitor Cells Derived From Embryonic Stem Cells Promote Functional Recovery After Transplantation Into Injured Spinal Cord of Nonhuman Primates. Stem Cells Transl Med. 2015;4(7):708-19.

174. Fischer I, Dulin JN, Lane MA. Transplanting neural progenitor cells to restore connectivity after spinal cord injury. Nat Rev Neurosci. 2020 Jul;21(7):366-83.

175. Rosenzweig ES, Brock JH, Lu P, Kumamaru H, Salegio EA, Kadoya $\mathrm{K}$, et al. Restorative effects of human neural stem cell grafts on the primate spinal cord. Nat Med. 2018;24(4):484-90. 
176. Anderson KD, Guest JD, Dietrich WD, Bartlett Bunge M, Curiel $R$, Dididze M, et al. Safety of Autologous Human Schwann Cell Transplantation in Subacute Thoracic Spinal Cord Injury. Journal of Neurotrauma. 2017 Feb 18;34(21):2950-63.

177. Sharp J, Frame J, Siegenthaler M, Nistor G, Keirstead HS. Human embryonic stem cell-derived oligodendrocyte progenitor cell transplants improve recovery after cervical spinal cord injury. Stem Cells. 2010 Jan;28(1):152-63.

178. Zholudeva LV, lyer N, Qiang L, Spruance VM, Randelman ML, White NW, et al. Transplantation of Neural Progenitors and V2a Interneurons after Spinal Cord Injury. Journal of Neurotrauma. 2018 Jun 6;35(24):2883-903.

179. Kumagai G, Tsoulfas P, Toh S, McNiece I, Bramlett HM, Dietrich WD. Genetically modified mesenchymal stem cells (MSCs) promote axonal regeneration and prevent hypersensitivity after spinal cord injury. Exp Neurol. 2013 Oct;248:369-80.

180. Reynolds BA, Weiss S. Generation of neurons and astrocytes from isolated cells of the adult mammalian central nervous system. Science. 1992 Mar 27;255(5052):1707-10.

181. Shimazaki T, Shingo T, Weiss S. The Ciliary Neurotrophic Factor/Leukemia Inhibitory Factor/gp130 Receptor Complex Operates in the Maintenance of Mammalian Forebrain Neural Stem Cells. J Neurosci. 2001 Oct 1;21(19):7642-53.

182. Belenguer G, Domingo-Muelas A, Ferrón SR, Morante-Redolat $\mathrm{JM}$, Fariñas I. Isolation, culture and analysis of adult subependymal neural stem cells. Differentiation. 2016 Jun;91(4-5):28-41.

183. McGrath EL, Gao J, Wu P. Proliferation and differentiation of human fetal brain neural stem cells in vitro. JN. 2018 Jan 10;6:19-27. 
184. Ma DK, Bonaguidi MA, Ming G, Song H. Adult neural stem cells in the mammalian central nervous system. Cell Res. 2009 Jun;19(6):672-82.

185. Doetsch F, Caillé I, Lim DA, García-Verdugo JM, Alvarez-Buylla A. Subventricular zone astrocytes are neural stem cells in the adult mammalian brain. Cell. 1999 Jun 11;97(6):703-16.

186. Seri B, García-Verdugo JM, McEwen BS, Alvarez-Buylla A. Astrocytes give rise to new neurons in the adult mammalian hippocampus. J Neurosci. 2001 Sep 15;21(18):7153-60.

187. Duan X, Kang E, Liu CY, Ming G, Song H. Development of neural stem cell in the adult brain. Curr Opin Neurobiol. 2008 Feb;18(1):108-15.

188. Dulin JN, Lu P. Bridging the injured spinal cord with neural stem cells. Neural Regeneration Res. 2014;9(3):229-31.

189. Abematsu M, Tsujimura K, Yamano M, Saito M, Kohno K, Kohyama J, et al. Neurons derived from transplanted neural stem cells restore disrupted neuronal circuitry in a mouse model of spinal cord injury. J Clin Invest. 2010;120(9):3255-66.

190. Cheng Z, Bosco DB, Sun L, Chen X, Xu Y, Tai W, et al. Neural Stem Cell-Conditioned Medium Suppresses Inflammation and Promotes Spinal Cord Injury Recovery. Cell Transplant. 2017;26(3):469-82.

191. Rong Y, Liu W, Wang J, Fan J, Luo Y, Li L, et al. Neural stem cellderived small extracellular vesicles attenuate apoptosis and neuroinflammation after traumatic spinal cord injury by activating autophagy. Cell Death Dis. 2019;10(5):340.

192. Ceto S, Sekiguchi KJ, Takashima Y, Nimmerjahn A, Tuszynski $\mathrm{MH}$. Neural Stem Cell Grafts Form Extensive Synaptic Networks that Integrate with Host Circuits after Spinal Cord Injury. Cell Stem Cell. 2020 Sep 3;27(3):430-440.e5. 
193. Lu P, Wang Y, Graham L, McHale K, Gao M, Wu D, et al. Longdistance growth and connectivity of neural stem cells after severe spinal cord injury. Cell. 2012;150(6):1264-73.

194. Lu P, Jones LL, Snyder EY, Tuszynski MH. Neural stem cells constitutively secrete neurotrophic factors and promote extensive host axonal growth after spinal cord injury. Exp Neurol. 2003 Jun;181(2):115-29.

195. Li Z, Guo G-H, Wang G-S, Guan C-X, Yue L. Influence of neural stem cell transplantation on angiogenesis in rats with spinal cord injury. Genet Mol Res. 2014 Aug 7;13(3):6083-92.

196. Amemori T, Romanyuk N, Jendelova P, Herynek V, Turnovcova $\mathrm{K}$, Prochazka $\mathrm{P}$, et al. Human conditionally immortalized neural stem cells improve locomotor function after spinal cord injury in the rat. Stem Cell Res Ther. 2013 Jun 7;4(3):68.

197. Yokota K, Kobayakawa K, Kubota K, Miyawaki A, Okano H, Ohkawa $Y$, et al. Engrafted Neural Stem/Progenitor Cells Promote Functional Recovery through Synapse Reorganization with Spared Host Neurons after Spinal Cord Injury. Stem Cell Reports. 2015 Aug 11;5(2):264-77.

198. Nori S, Khazaei M, Ahuja CS, Yokota K, Ahlfors J-E, Liu Y, et al. Human Oligodendrogenic Neural Progenitor Cells Delivered with Chondroitinase ABC Facilitate Functional Repair of Chronic Spinal Cord Injury. Stem Cell Reports. 2018 Dec 11;11(6):143348.

199. Khazaei M, Ahuja CS, Nakashima H, Nagoshi N, Li L, Wang J, et al. GDNF rescues the fate of neural progenitor grafts by attenuating Notch signals in the injured spinal cord in rodents. Sci Transl Med. 2020 Jan 8;12(525).

200. Moreno-Manzano V, Rodríguez-Jiménez FJ, García-Roselló M, Laínez S, Erceg S, Calvo MT, et al. Activated spinal cord ependymal stem cells rescue neurological function. Stem Cells. 2009 Mar;27(3):733-43. 
201. Alastrue-Agudo A, Rodriguez-Jimenez FJ, Mocholi EL, De Giorgio F, Erceg S, Moreno-Manzano V. FM19G11 and Ependymal Progenitor/Stem Cell Combinatory Treatment Enhances Neuronal Preservation and Oligodendrogenesis after Severe Spinal Cord Injury. Int J Mol Sci. 2018 Jan 9;19(1).

202. Giraldo E, Nebot VJ, Đorđević S, Requejo-Aguilar R, AlastrueAgudo $A$, Zagorodko $O$, et al. A rationally designed selfimmolative linker enhances the synergism between a polymerrock inhibitor conjugate and neural progenitor cells in the treatment of spinal cord injury. Biomaterials. 2021 Sep;276:121052.

203. Hoshino K, Takeuchi O, Kawai T, Sanjo H, Ogawa T, Takeda Y, et al. Cutting edge: Toll-like receptor 4 (TLR4)-deficient mice are hyporesponsive to lipopolysaccharide: evidence for TLR4 as the Lps gene product. J Immunol. 1999 Apr 1;162(7):3749-52.

204. Geissler SA, Schmidt CE, Schallert T. Rodent Models and Behavioral Outcomes of Cervical Spinal Cord Injury. J Spine [Internet]. 2013 Jul 27 [cited 2021 Apr 27];Suppl 4. Available from:

https://www.ncbi.nlm.nih.gov/pmc/articles/PMC4191831/

205. Vogelaar CF, Estrada V. Experimental Spinal Cord Injury Models in Rodents: Anatomical Correlations and Assessment of Motor Recovery. Recovery of Motor Function Following Spinal Cord Injury. 2016; undefined-undefined.

206. Plemel JR, Duncan G, Chen K-WK, Shannon C, Park S, Sparling JS, et al. A graded forceps crush spinal cord injury model in mice. J Neurotrauma. 2008 Apr;25(4):350-70.

207. Iwai H, Nori S, Nishimura S, Yasuda A, Takano M, Tsuji O, et al. Transplantation of neural stem/progenitor cells at different locations in mice with spinal cord injury. Cell Transplant. 2014;23(11):1451-64.

208. Metz GA, Whishaw IQ. Cortical and subcortical lesions impair skilled walking in the ladder rung walking test: a new task to 
evaluate fore- and hindlimb stepping, placing, and coordination. J Neurosci Methods. 2002 Apr 15;115(2):169-79.

209. Cummings BJ, Engesser-Cesar C, Cadena G, Anderson AJ. Adaptation of a ladder beam walking task to assess locomotor recovery in mice following spinal cord injury. Behav Brain Res. 2007 Feb 27;177(2):232-41.

210. Basso DM, Fisher LC, Anderson AJ, Jakeman LB, McTigue DM, Popovich PG. Basso Mouse Scale for locomotion detects differences in recovery after spinal cord injury in five common mouse strains. J Neurotrauma. 2006 May;23(5):635-59.

211. Hamers FP, Lankhorst AJ, van Laar TJ, Veldhuis WB, Gispen WH. Automated quantitative gait analysis during overground locomotion in the rat: its application to spinal cord contusion and transection injuries. J Neurotrauma. 2001 Feb;18(2):187201.

212. Fagoe ND, Attwell CL, Eggers R, Tuinenbreijer L, Kouwenhoven $D$, Verhaagen J, et al. Evaluation of Five Tests for Sensitivity to Functional Deficits following Cervical or Thoracic Dorsal Column Transection in the Rat. PLoS One. 2016;11(3):e0150141.

213. Weischenfeldt J, Porse B. Bone Marrow-Derived Macrophages (BMM): Isolation and Applications. Cold Spring Harb Protoc. 2008 Jan 12;2008(12):pdb.prot5080.

214. Butovsky O, Jedrychowski MP, Moore CS, Cialic R, Lanser AJ, Gabriely G, et al. Identification of a unique TGF- $\beta$-dependent molecular and functional signature in microglia. Nat Neurosci. 2014 Jan;17(1):131-43.

215. Daukste L, Basse B, Baguley B, Wall D. Mathematical Determination of Cell Population Doubling Times for Multiple Cell Lines. Bulletin of mathematical biology. 2012 Aug 23;74:2510-34. 
216. Ding B, Kilpatrick DL. Lentiviral vector production, titration, and transduction of primary neurons. Methods Mol Biol. 2013;1018:119-31.

217. Shabram P, Aguilar-Cordova E. Multiplicity of Infection/Multiplicity of Confusion. Molecular Therapy. 2000 Nov 1;2(5):420-1.

218. Mandelkow R, Gümbel D, Ahrend H, Kaul A, Zimmermann U, Burchardt $M$, et al. Detection and Quantification of Nuclear Morphology Changes in Apoptotic Cells by Fluorescence Microscopy and Subsequent Analysis of Visualized Fluorescent Signals. Anticancer Res. 2017 May;37(5):2239-44.

219. Livak KJ, Schmittgen TD. Analysis of relative gene expression data using real-time quantitative PCR and the 2(-Delta Delta C(T)) Method. Methods. 2001 Dec;25(4):402-8.

220. Weiss S, Reynolds BA, Vescovi AL, Morshead C, Craig CG, van der Kooy $D$. Is there a neural stem cell in the mammalian forebrain? Trends Neurosci. 1996 Sep;19(9):387-93.

221. Shihabuddin LS, Ray J, Gage FH. FGF-2 is sufficient to isolate progenitors found in the adult mammalian spinal cord. Exp Neurol. 1997 Dec;148(2):577-86.

222. Martens DJ, Seaberg RM, van der Kooy D. In vivo infusions of exogenous growth factors into the fourth ventricle of the adult mouse brain increase the proliferation of neural progenitors around the fourth ventricle and the central canal of the spinal cord. Eur J Neurosci. 2002 Sep;16(6):1045-57.

223. Johansson CB, Momma S, Clarke DL, Risling M, Lendahl U, Frisén J. Identification of a neural stem cell in the adult mammalian central nervous system. Cell. 1999 Jan 8;96(1):25-34.

224. Bruni JE. Ependymal development, proliferation, and functions: a review. Microsc Res Tech. 1998 Apr 1;41(1):2-13. 
225. Parr AM, Kulbatski I, Tator $\mathrm{CH}$. Transplantation of adult rat spinal cord stem/progenitor cells for spinal cord injury. J Neurotrauma. 2007 May;24(5):835-45.

226. Mothe AJ, Tator $\mathrm{CH}$. Proliferation, migration, and differentiation of endogenous ependymal region stem/progenitor cells following minimal spinal cord injury in the adult rat. Neuroscience. 2005;131(1):177-87.

227. Meletis K, Barnabé-Heider F, Carlén M, Evergren E, Tomilin N, Shupliakov $\mathrm{O}$, et al. Spinal Cord Injury Reveals Multilineage Differentiation of Ependymal Cells. PLOS Biology. 2008 Jul 22;6(7):e182.

228. Rodriguez-Jimenez FJ, Alastrue A, Stojkovic M, Erceg S, MorenoManzano V. Connexin 50 modulates Sox 2 expression in spinalcord-derived ependymal stem/progenitor cells. Cell Tissue Res. 2016 Aug;365(2):295-307.

229. Paniagua-Torija B, Norenberg M, Arevalo-Martin A, CarballosaGautam MM, Campos-Martin Y, Molina-Holgado E, et al. Cells in the adult human spinal cord ependymal region do not proliferate after injury. J Pathol. 2018 Dec;246(4):415-21.

230. Gómez-Villafuertes R, Rodríguez-Jiménez FJ, Alastrue-Agudo A, Stojkovic M, Miras-Portugal MT, Moreno-Manzano V. Purinergic Receptors in Spinal Cord-Derived Ependymal Stem/Progenitor Cells and Their Potential Role in Cell-Based Therapy for Spinal Cord Injury. Cell Transplant. 2015 Aug 1;24(8):1493-509.

231. Nishimura M, Naito $\mathrm{S}$. Tissue-specific mRNA expression profiles of human toll-like receptors and related genes. Biol Pharm Bull. 2005 May;28(5):886-92.

232. Heiman A, Pallottie A, Heary RF, Elkabes S. Toll-like receptors in central nervous system injury and disease: A focus on the spinal cord. Brain, Behavior, and Immunity. 2014 Nov 1;42:232-45. 
233. Popovich PG, Guan Z, McGaughy V, Fisher L, Hickey WF, Basso $D M$. The neuropathological and behavioral consequences of intraspinal microglial/macrophage activation. J Neuropathol Exp Neurol. 2002 Jul;61(7):623-33.

234. Alvarado AG, Lathia JD. Taking a Toll on Self-Renewal: TLRMediated Innate Immune Signaling in Stem Cells. Trends Neurosci. 2016 Jul;39(7):463-71.

235. Covacu R, Arvidsson L, Andersson $\AA$, Khademi M, ErlandssonHarris $H$, Harris RA, et al. TLR Activation Induces TNF- $\alpha$ Production from Adult Neural Stem/Progenitor Cells. The Journal of Immunology. 2009 Jun 1;182(11):6889-95.

236. Suh H, Consiglio A, Ray J, Sawai T, D'Amour KA, Gage FH. In vivo fate analysis reveals the multipotent and self-renewal capacities of Sox $2+$ neural stem cells in the adult hippocampus. Cell Stem Cell. 2007 Nov;1(5):515-28.

237. Hoffmann SA, Hos D, Küspert M, Lang RA, Lovell-Badge $R$, Wegner $M$, et al. Stem cell factor Sox2 and its close relative Sox3 have differentiation functions in oligodendrocytes. Development. 2014 Jan;141(1):39-50.

238. Avilion AA, Nicolis SK, Pevny LH, Perez L, Vivian N, Lovell-Badge R. Multipotent cell lineages in early mouse development depend on SOX2 function. Genes Dev. 2003 Jan 1;17(1):126-40.

239. Bylund M, Andersson E, Novitch BG, Muhr J. Vertebrate neurogenesis is counteracted by Sox1-3 activity. Nat Neurosci. 2003 Nov;6(11):1162-8.

240. Kim JB, Zaehres H, Wu G, Gentile L, Ko K, Sebastiano V, et al. Pluripotent stem cells induced from adult neural stem cells by reprogramming with two factors. Nature. 2008 Jul 31;454(7204):646-50.

241. Zhao C, Ma D, Zawadzka M, Fancy SPJ, Elis-Williams L, Bouvier $G$, et al. Sox2 Sustains Recruitment of Oligodendrocyte Progenitor Cells following CNS Demyelination and Primes Them 
for Differentiation during Remyelination. J Neurosci. 2015 Aug 19;35(33):11482-99.

242. Ferri ALM, Cavallaro M, Braida D, Di Cristofano A, Canta A, Vezzani $A$, et al. Sox 2 deficiency causes neurodegeneration and impaired neurogenesis in the adult mouse brain. Development. 2004 Aug;131(15):3805-19.

243. Briley D, Ghirardi V, Woltjer R, Renck A, Zolochevska O, Taglialatela $\mathrm{G}$, et al. Preserved neurogenesis in non-demented individuals with AD neuropathology. Scientific Reports. 2016 Jun 14;6:27812.

244. Decimo I, Fumagalli G, Berton V, Krampera M, Bifari $F$. Meninges: from protective membrane to stem cell niche. Am J Stem Cells. 2012;1(2):92-105.

245. Fernandez-Lizarbe S, Montesinos J, Guerri C. Ethanol induces TLR4/TLR2 association, triggering an inflammatory response in microglial cells. J Neurochem. 2013 Jul;126(2):261-73.

246. Gong W, Li J, Chen W, Feng F, Deng Y. Resveratrol Inhibits Lipopolysaccharide-Induced Extracellular Matrix Accumulation and Inflammation in Rat Glomerular Mesangial Cells by SphK1/S1P2/NF-kB Pathway. Diabetes Metab Syndr Obes. 2020 Nov 20;13:4495-505.

247. Spassky N, Merkle FT, Flames N, Tramontin AD, García-Verdugo $\mathrm{JM}$, Alvarez-Buylla A. Adult ependymal cells are postmitotic and are derived from radial glial cells during embryogenesis. J Neurosci. 2005 Jan 5;25(1):10-8.

248. Moreno-Manzano V. Ependymal cells in the spinal cord as neuronal progenitors. Curr Opin Pharmacol. 2020 Feb;50:82-7.

249. Marichal N, García G, Radmilovich M, Trujillo-Cenóz O, Russo RE. Spatial domains of progenitor-like cells and functional complexity of a stem cell niche in the neonatal rat spinal cord. Stem Cells. 2012 Sep;30(9):2020-31. 
250. Kelly K, Cochran B, Stiles C, Leder P. The regulation of c-myc by growth signals. Curr Top Microbiol Immunol. 1984;113:117-26.

251. Graham V, Khudyakov J, Ellis P, Pevny L. SOX2 functions to maintain neural progenitor identity. Neuron. 2003 Aug 28;39(5):749-65.

252. Slovinska L, Szekiova E, Blasko J, Devaux S, Salzet M, Cizkova D. Comparison of dynamic behavior and maturation of neural multipotent cells derived from different spinal cord developmental stages: an in vitro study. Acta Neurobiol Exp (Wars). 2015;75(1):107-14.

253. Ropolo M, Daga A, Griffero F, Foresta M, Casartelli G, Zunino A, et al. Comparative analysis of DNA repair in stem and nonstem glioma cell cultures. Mol Cancer Res. 2009 Mar;7(3):383-92.

254. Ma Q, Sommer L, Cserjesi P, Anderson DJ. Mash1 and neurogenin1 expression patterns define complementary domains of neuroepithelium in the developing CNS and are correlated with regions expressing notch ligands. J Neurosci. 1997 May 15;17(10):3644-52.

255. Pekny $M$, Pekna $M$. Astrocyte reactivity and reactive astrogliosis: costs and benefits. Physiol Rev. 2014 Oct;94(4):1077-98.

256. Levine J, Kwon E, Paez P, Yan W, Czerwieniec G, Loo JA, et al. Traumatically injured astrocytes release a proteomic signature modulated by STAT3-dependent cell survival. Glia. 2016 May;64(5):668-94.

257. Lu QR, Park JK, Noll E, Chan JA, Alberta J, Yuk D, et al. Oligodendrocyte lineage genes (OLIG) as molecular markers for human glial brain tumors. Proc Natl Acad Sci U S A. 2001 Sep 11;98(19):10851-6.

258. Stolt CC, Rehberg S, Ader M, Lommes P, Riethmacher D, Schachner $M$, et al. Terminal differentiation of myelin-forming 
oligodendrocytes depends on the transcription factor Sox10. Genes Dev. 2002 Jan 15;16(2):165-70.

259. Polito A, Reynolds R. NG2-expressing cells as oligodendrocyte progenitors in the normal and demyelinated adult central nervous system. J Anat. 2005 Dec;207(6):707-16.

260. Zhao S, Nichols J, Smith AG, Li M. SoxB transcription factors specify neuroectodermal lineage choice in ES cells. Mol Cell Neurosci. 2004 Nov;27(3):332-42.

261. Takemoto T, Uchikawa M, Yoshida M, Bell DM, Lovell-Badge R, Papaioannou VE, et al. Tbx6-dependent Sox2 regulation determines neural vs mesodermal fate in axial stem cells. Nature. 2011 Feb 17;470(7334):394-8.

262. Baltus GA, Kowalski MP, Zhai H, Tutter AV, Quinn D, Wall D, et al. Acetylation of Sox2 Induces its Nuclear Export in Embryonic Stem Cells. STEM CELLS. 2009;27(9):2175-84.

263. Rodriguez-Jimenez FJ, Clemente E, Moreno-Manzano V, Erceg S. Organized Neurogenic-Niche-Like Pinwheel Structures Discovered in Spinal Cord Tissue-Derived Neurospheres. Front Cell Dev Biol. 2019;7:334.

264. Kokaia Z, Martino G, Schwartz M, Lindvall O. Cross-talk between neural stem cells and immune cells: the key to better brain repair? Nat Neurosci. 2012 Jul 26;15(8):1078-87.

265. Fan L-W, Pang Y. Dysregulation of neurogenesis by neuroinflammation: key differences in neurodevelopmental and neurological disorders. Neural Regen Res. 2017 Mar;12(3):366-71.

266. Song D, Qi F, Liu S, Tang Z, Duan J, Yao Z. The adoptive transfer of BCG-induced T lymphocytes contributes to hippocampal cell proliferation and tempers anxiety-like behavior in immune deficient mice. PLoS One. 2020;15(4):e0225874. 
267. Butovsky O, Ziv Y, Schwartz A, Landa G, Talpalar AE, Pluchino S, et al. Microglia activated by IL-4 or IFN-gamma differentially induce neurogenesis and oligodendrogenesis from adult stem/progenitor cells. Mol Cell Neurosci. 2006 Jan;31(1):14960.

268. Chien C-H, Lee M-J, Liou H-C, Liou H-H, Fu W-M. MicrogliaDerived Cytokines/Chemokines Are Involved in the Enhancement of LPS-Induced Loss of Nigrostriatal Dopaminergic Neurons in DJ-1 Knockout Mice. PLOS ONE. 2016 Mar 16;11(3):e0151569.

269. Bonni A, Sun Y, Nadal-Vicens M, Bhatt A, Frank DA, Rozovsky I, et al. Regulation of gliogenesis in the central nervous system by the JAK-STAT signaling pathway. Science. 1997 Oct 17;278(5337):477-83.

270. Molné M, Studer L, Tabar V, Ting YT, Eiden MV, McKay RD. Early cortical precursors do not undergo LIF-mediated astrocytic differentiation. J Neurosci Res. 2000 Feb 1;59(3):301-11.

271. Qian X, Shen Q, Goderie SK, He W, Capela A, Davis AA, et al. Timing of CNS cell generation: a programmed sequence of neuron and glial cell production from isolated murine cortical stem cells. Neuron. 2000 Oct;28(1):69-80.

272. Lee H-C, Tan K-L, Cheah P-S, Ling K-H. Potential Role of JAK-STAT Signaling Pathway in the Neurogenic-to-Gliogenic Shift in Down Syndrome Brain. Neural Plast. 2016;2016:7434191.

273. Sauerbeck A, Schonberg DL, Laws JL, McTigue DM. Systemic iron chelation results in limited functional and histological recovery after traumatic spinal cord injury in rats. Exp Neurol. 2013 Oct;248:53-61.

274. Urrutia P, Aguirre P, Esparza A, Tapia V, Mena NP, Arredondo $M$, et al. Inflammation alters the expression of DMT1, FPN1 and hepcidin, and it causes iron accumulation in central nervous system cells. Journal of Neurochemistry. 2013;126(4):541-9. 
275. Lim H, Gwon M, Lee SJ. Toll-like receptor 2 signaling induces interferon regulatory factor 8 expression in spinal cord microglia after peripheral nerve injury. Itch \& Pain [Internet]. 2016 [cited 2021 May 2];3. Available from: https://www.smartscitech.com/index.php/IP/article/view/741

276. Kim D, Kim MA, Cho I-H, Kim MS, Lee S, Jo E-K, et al. A Critical Role of Toll-like Receptor 2 in Nerve Injury-induced Spinal Cord Glial Cell Activation and Pain Hypersensitivity*. Journal of Biological Chemistry. 2007 May 18;282(20):14975-83.

277. Shi XQ, Zekki $H$, Zhang J. The role of TLR2 in nerve injuryinduced neuropathic pain is essentially mediated through macrophages in peripheral inflammatory response. Glia. 2011;59(2):231-41.

278. Streilein JW. Immune privilege as the result of local tissue barriers and immunosuppressive microenvironments. Curr Opin Immunol. 1993 Jun;5(3):428-32.

279. Sloan DJ, Wood MJ, Charlton HM. The immune response to intracerebral neural grafts. Trends in Neurosciences. 1991 Aug 1;14(8):341-6.

280. Zhang X, Deriaud E, Jiao X, Braun D, Leclerc C, Lo-Man R. Type I interferons protect neonates from acute inflammation through interleukin 10-producing B cells. J Exp Med. 2007 May 14;204(5):1107-18.

281. Walker WE, Goldstein DR. Neonatal B cells suppress innate tolllike receptor immune responses and modulate alloimmunity. J Immunol. 2007 Aug 1;179(3):1700-10.

282. Alegre M-L, Goldstein DR, Chong AS. Toll-like receptor signaling in transplantation. Curr Opin Organ Transplant. 2008 Aug;13(4):358-65.

283. Vignali DAA, Collison LW, Workman CJ. How regulatory T cells work. Nature Reviews Immunology. 2008 Jul;8(7):523-32. 
284. Kidd P. Th1/Th2 balance: the hypothesis, its limitations, and implications for health and disease. Altern Med Rev. 2003 Aug;8(3):223-46.

285. Hanidziar D, Koulmanda M. Inflammation and the balance of Treg and Th17 cells in transplant rejection and tolerance. Curr Opin Organ Transplant. 2010 Aug;15(4):411-5.

286. Rau C-S, Lin M-W, Wu S-C, Wu Y-C, Lu T-H, Tzeng S-L, et al. Regulatory and Effector Helper T-Cell Profile after Nerve Xenografting in the Toll-Like Receptor-Deficient Mice. Int J Med Sci. 2015;12(8):650-4.

287. Zhang N, Krüger B, Lal G, Luan $\mathrm{Y}$, Yadav A, Zang $\mathrm{W}$, et al. Inhibition of TLR4 signaling prolongs Treg-dependent murine islet allograft survival. Immunol Lett. 2010 Jan 4;127(2):119-25.

288. Wasko NJ, Kulak MH, Paul D, Nicaise AM, Yeung ST, Nichols FC, et al. Systemic TLR2 tolerance enhances central nervous system remyelination. Journal of Neuroinflammation. $2019 \mathrm{Jul}$ 27;16(1):158.

289. Ruzicka J, Machova-Urdzikova L, Gillick J, Amemori T, Romanyuk N, Karova K, et al. A Comparative Study of Three Different Types of Stem Cells for Treatment of Rat Spinal Cord Injury. Cell Transplant. 2017 Apr;26(4):585-603.

290. Cheng Z, Zhu W, Cao K, Wu F, Li J, Wang G, et al. AntiInflammatory Mechanism of Neural Stem Cell Transplantation in Spinal Cord Injury. Int J Mol Sci. 2016 Aug 23;17(9).

291. Cheng Z, Bosco DB, Sun L, Chen X, Xu Y, Tai W, et al. Neural Stem Cell-Conditioned Medium Suppresses Inflammation and Promotes Spinal Cord Injury Recovery. Cell Transplant. 2017 Mar 13;26(3):469-82.

292. Karova K, Wainwright JV, Machova-Urdzikova L, Pisal RV, Schmidt $M$, Jendelova $P$, et al. Transplantation of neural precursors generated from spinal progenitor cells reduces 
inflammation in spinal cord injury via NF-kB pathway inhibition. Journal of Neuroinflammation. 2019 Jan 17;16(1):12.

293. Sankavaram SR, Hakim R, Covacu R, Frostell A, Neumann S, Svensson $M$, et al. Adult Neural Progenitor Cells Transplanted into Spinal Cord Injury Differentiate into Oligodendrocytes, Enhance Myelination, and Contribute to Recovery. Stem Cell Reports. 2019 Apr 25;12(5):950-66.

294. Soblosky JS, Song JH, Dinh DH. Graded unilateral cervical spinal cord injury in the rat: evaluation of forelimb recovery and histological effects. Behav Brain Res. 2001 Feb 15;119(1):1-13.

295. Eisdorfer JT, Phelan MA, Keefe KM, Rollins MM, lii TJC, Rauscher $\mathrm{KM}$, et al. Addition of angled rungs to the horizontal ladder walking task for more sensitive probing of sensorimotor changes. PLOS ONE. 2021 Feb 5;16(2):e0246298.

296. Ahmed R, Alam M, Zheng Y-P. Experimental spinal cord injury and behavioral tests in laboratory rats. Heliyon. 2019 Mar 8;5.

297. Kameda T, Kaneuchi Y, Sekiguchi M, Konno S. Measurement of mechanical withdrawal thresholds and gait analysis using the CatWalk method in a nucleus pulposus-applied rodent model. J Exp Orthop [Internet]. 2017 Sep 29 [cited 2021 May 24];4. Available from: https://www.ncbi.nlm.nih.gov/pmc/articles/PMC5624862/

298. Cao Q-L, Howard RM, Dennison JB, Whittemore SR. Differentiation of engrafted neuronal-restricted precursor cells is inhibited in the traumatically injured spinal cord. Exp Neurol. 2002 Oct;177(2):349-59.

299. Yang Z, Wang KKW. Glial fibrillary acidic protein: from intermediate filament assembly and gliosis to neurobiomarker. Trends Neurosci. 2015 Jun;38(6):364-74.

300. Damoiseaux JG, Döpp EA, Calame W, Chao D, MacPherson GG, Dijkstra CD. Rat macrophage lysosomal membrane antigen 
recognized by monoclonal antibody ED1. Immunology. 1994 Sep;83(1):140-7.

301. Ito D, Imai Y, Ohsawa K, Nakajima K, Fukuuchi Y, Kohsaka S. Microglia-specific localisation of a novel calcium binding protein, Iba1. Brain Res Mol Brain Res. 1998 Jun 1;57(1):1-9.

302. Wu Q, Zhang Y, Zhang Y, Zhang W, Zhang W, Liu Y, et al. Riluzole improves functional recovery after acute spinal cord injury in rats and may be associated with changes in spinal microglia/macrophages polarization. Neurosci Lett. 2020 Apr 1;723:134829.

303. Garraway SM, Huie JR. Spinal Plasticity and Behavior: BDNFInduced Neuromodulation in Uninjured and Injured Spinal Cord. Neural Plast. 2016;2016:9857201.

304. Dong J, Pan Y-B, Wu X-R, He L-N, Liu X-D, Feng D-F, et al. A neuronal molecular switch through cell-cell contact that regulates quiescent neural stem cells. Science Advances. 2019 Feb 1;5(2):eaav4416.

305. Pemberton JM, Pogmore JP, Andrews DW. Neuronal cell life, death, and axonal degeneration as regulated by the BCL-2 family proteins. Cell Death Differ. 2021 Jan;28(1):108-22.

306. Isaksson J, Farooque M, Olsson Y. Improved functional outcome after spinal cord injury in iNOS-deficient mice. Spinal Cord. 2005 Mar;43(3):167-70.

307. Xu J, Kim GM, Chen S, Yan P, Ahmed SH, Ku G, et al. iNOS and nitrotyrosine expression after spinal cord injury. J Neurotrauma. 2001 May;18(5):523-32.

308. Clark PJ, Kohman RA, Miller DS, Bhattacharya TK, Haferkamp $\mathrm{EH}$, Rhodes JS. Adult hippocampal neurogenesis and c-Fos induction during escalation of voluntary wheel running in C57BL/6J mice. Behav Brain Res. 2010 Dec 1;213(2):246-52. 
309. Herrmann JE, Imura T, Song B, Qi J, Ao Y, Nguyen TK, et al. STAT3 is a critical regulator of astrogliosis and scar formation after spinal cord injury. J Neurosci. 2008 Jul 9;28(28):7231-43.

310. Chio JCT, Xu KJ, Popovich P, David S, Fehlings MG. Neuroimmunological therapies for treating spinal cord injury: Evidence and future perspectives. Experimental Neurology. 2021 Jul 1;341:113704.

311. Bernardes D, Oliveira ALR. Comprehensive catwalk gait analysis in a chronic model of multiple sclerosis subjected to treadmill exercise training. BMC Neurol. 2017 Aug 22;17(1):160.

312. He B-L, Ba Y-C, Wang X-Y, Liu S, Liu G-D, Ou S, et al. BDNF expression with functional improvement in transected spinal cord treated with neural stem cells in adult rats. Neuropeptides. 2012 Sep 5;47.

313. Palma-Tortosa S, Hurtado O, Pradillo JM, Ferreras-Martín R, García-Yébenes I, García-Culebras A, et al. Toll-like receptor 4 regulates subventricular zone proliferation and neuroblast migration after experimental stroke. Brain Behav Immun. 2019 Aug;80:573-82.

314. Houlé JD, Côté M-P. Axon regeneration and exercisedependent plasticity after spinal cord injury. Ann N Y Acad Sci. 2013 Apr;1279(1):154-63.

315. Bonner JF, Haas CJ, Fischer I. Preparation of neural stem cells and progenitors: neuronal production and grafting applications. Methods Mol Biol. 2013;1078:65-88.

316. Ribeiro $P$, Castro MV, Perez $M$, Cartarozzi LP, Spejo $A B$, Chiarotto GB, et al. Toll-like receptor 4 (TLR4) influences the glial reaction in the spinal cord and the neural response to injury following peripheral nerve crush. Brain Research Bulletin. 2020 Feb 1;155:67-80.

317. Freria CM, Velloso LA, Oliveira AL. Opposing effects of Toll-like receptors 2 and 4 on synaptic stability in the spinal cord after 
peripheral nerve injury. Journal of Neuroinflammation. 2012 Oct 23;9(1):240.

318. Pan D, Li Y, Yang F, Lv Z, Zhu S, Shao Y, et al. Increasing toll-like receptor 2 on astrocytes induced by Schwann cell-derived exosomes promotes recovery by inhibiting CSPGs deposition after spinal cord injury. Journal of Neuroinflammation. 2021 Aug 9;18(1):172.

319. Zhang X, Shan P, Qureshi S, Homer R, Medzhitov R, Noble PW, et al. Cutting edge: TLR4 deficiency confers susceptibility to lethal oxidant lung injury. J Immunol. 2005 Oct 15;175(8):48348.

320. Kwak EK, Kim JW, Kang KS, Lee YH, Hua QH, Park TI, et al. The Role of Inducible Nitric Oxide Synthase Following Spinal Cord Injury in Rat. J Korean Med Sci. 2005 Aug;20(4):663-9.

321. Kigerl KA, Lai W, Rivest S, Hart RP, Satoskar AR, Popovich PG. Toll-like receptor (TLR)-2 and TLR-4 regulate inflammation, gliosis, and myelin sparing after spinal cord injury. J Neurochem. 2007 Jul;102(1):37-50.

322. Hartmann M, Heumann R, Lessmann V. Synaptic secretion of BDNF after high-frequency stimulation of glutamatergic synapses. EMBO J. 2001 Nov 1;20(21):5887-97.

323. McDonough A, Martínez-Cerdeño V. Endogenous Proliferation after Spinal Cord Injury in Animal Models. Stem Cells International. 2012 Dec 20;2012:e387513.

324. Wang B, Liu S, Fan B, Xu X, Chen Y, Lu R, et al. PKM2 is involved in neuropathic pain by regulating ERK and STAT3 activation in rat spinal cord. J Headache Pain. 2018 Jan 18;19(1):7.

325. Renault-Mihara F, Mukaino $M$, Shinozaki $M$, Kumamaru $H$, Kawase S, Baudoux M, et al. Regulation of RhoA by STAT3 coordinates glial scar formation. J Cell Biol. 2017 Aug 7;216(8):2533-50. 
326. Llorens-Bobadilla E, Chell JM, Le Merre $\mathrm{P}, \mathrm{Wu} \mathrm{Y}$, Zamboni $\mathrm{M}$, Bergenstråhle J, et al. A latent lineage potential in resident neural stem cells enables spinal cord repair. Science. 2020 Oct 2;370(6512):eabb8795.

327. Kerschensteiner M, Schwab ME, Lichtman JW, Misgeld T. In vivo imaging of axonal degeneration and regeneration in the injured spinal cord. Nat Med. 2005 May;11(5):572-7.

328. Wilcox JT, Satkunendrarajah K, Zuccato JA, Nassiri F, Fehlings MG. Neural precursor cell transplantation enhances functional recovery and reduces astrogliosis in bilateral compressive/contusive cervical spinal cord injury. Stem Cells Transl Med. 2014 Oct;3(10):1148-59.

329. Yang T, Dai Y, Chen G, Cui S. Dissecting the Dual Role of the Glial Scar and Scar-Forming Astrocytes in Spinal Cord Injury. Front Cell Neurosci. 2020;14:78.

330. Ughrin YM, Chen ZJ, Levine JM. Multiple regions of the NG2 proteoglycan inhibit neurite growth and induce growth cone collapse. J Neurosci. 2003 Jan 1;23(1):175-86.

331. Cregg JM, DePaul MA, Filous AR, Lang BT, Tran A, Silver J. Functional regeneration beyond the glial scar. Exp Neurol. 2014 Mar;253:197-207.

332. Gaudet AD, Popovich PG. Extracellular matrix regulation of inflammation in the healthy and injured spinal cord. Exp Neurol. 2014 Aug;258:24-34.

333. Silver J, Miller JH. Regeneration beyond the glial scar. Nat Rev Neurosci. 2004 Feb;5(2):146-56.

334. Kigerl KA, Gensel JC, Ankeny DP, Alexander JK, Donnelly DJ, Popovich PG. Identification of Two Distinct Macrophage Subsets with Divergent Effects Causing either Neurotoxicity or Regeneration in the Injured Mouse Spinal Cord. J Neurosci. 2009 Oct 28;29(43):13435-44. 
335. Camand E, Morel M-P, Faissner A, Sotelo C, Dusart I. Long-term changes in the molecular composition of the glial scar and progressive increase of serotoninergic fibre sprouting after hemisection of the mouse spinal cord. Eur J Neurosci. 2004 Sep;20(5):1161-76.

336. Göritz C, Dias DO, Tomilin N, Barbacid M, Shupliakov O, Frisén J. A pericyte origin of spinal cord scar tissue. Science. $2011 \mathrm{Jul}$ 8;333(6039):238-42.

337. Sorokin L. The impact of the extracellular matrix on inflammation. Nat Rev Immunol. 2010 Oct;10(10):712-23.

338. Heindryckx F, Li J-P. Role of proteoglycans in neuroinflammation and central nervous system fibrosis. Matrix Biol. 2018 Aug;68-69:589-601.

339. Rolls A, Shechter R, London A, Segev Y, Jacob-Hirsch J, Amariglio $\mathrm{N}$, et al. Two faces of chondroitin sulfate proteoglycan in spinal cord repair: a role in microglia/macrophage activation. PLoS Med. 2008 Aug 19;5(8):e171.

340. Bradbury EJ, Moon LDF, Popat RJ, King VR, Bennett GS, Patel $\mathrm{PN}$, et al. Chondroitinase $A B C$ promotes functional recovery after spinal cord injury. Nature. 2002 Apr 11;416(6881):636-40.

341. Massey JM, Hubscher $\mathrm{CH}$, Wagoner MR, Decker JA, Amps J, Silver J, et al. Chondroitinase $A B C$ digestion of the perineuronal net promotes functional collateral sprouting in the cuneate nucleus after cervical spinal cord injury. J Neurosci. $2006 \mathrm{Apr}$ 19;26(16):4406-14.

342. Galtrey CM, Asher RA, Nothias F, Fawcett JW. Promoting plasticity in the spinal cord with chondroitinase improves functional recovery after peripheral nerve repair. Brain. 2007 Apr;130(Pt 4):926-39.

343. Carter LM, Starkey ML, Akrimi SF, Davies M, McMahon SB, Bradbury EJ. The Yellow Fluorescent Protein (YFP-H) Mouse Reveals Neuroprotection as a Novel Mechanism Underlying 
Chondroitinase ABC-Mediated Repair after Spinal Cord Injury. J Neurosci. 2008 Dec 24;28(52):14107-20.

344. García-Alías G, Petrosyan HA, Schnell L, Horner PJ, Bowers WJ, Mendell LM, et al. Chondroitinase ABC combined with neurotrophin NT-3 secretion and NR2D expression promotes axonal plasticity and functional recovery in rats with lateral hemisection of the spinal cord. J Neurosci. 2011 Dec 7;31(49):17788-99.

345. Didangelos A, Iberl M, Vinsland E, Bartus K, Bradbury EJ. Regulation of IL-10 by chondroitinase $A B C$ promotes a distinct immune response following spinal cord injury. J Neurosci. 2014 Dec 3;34(49):16424-32.

346. Dyck S, Kataria H, Alizadeh A, Santhosh KT, Lang B, Silver J, et al. Perturbing chondroitin sulfate proteoglycan signaling through LAR and PTP $\sigma$ receptors promotes a beneficial inflammatory response following spinal cord injury. J Neuroinflammation. 2018 Mar 20;15(1):90.

347. Stephenson EL, Mishra MK, Moussienko D, Laflamme N, Rivest $\mathrm{S}$, Ling $\mathrm{C}-\mathrm{C}$, et al. Chondroitin sulfate proteoglycans as novel drivers of leucocyte infiltration in multiple sclerosis. Brain. 2018 Apr 1;141(4):1094-110.

348. Fisher D, Xing B, Dill J, Li H, Hoang HH, Zhao Z, et al. Leukocyte common antigen-related phosphatase is a functional receptor for chondroitin sulfate proteoglycan axon growth inhibitors. J Neurosci. 2011 Oct 5;31(40):14051-66.

349. Katagiri Y, Morgan AA, Yu P, Bangayan NJ, Junka R, Geller HM. Identification of novel binding sites for heparin in receptor protein-tyrosine phosphatase (RPTP $\sigma$ ): Implications for proteoglycan signaling. J Biol Chem. 2018 Jul 20;293(29):11639-47.

350. Li L, Ni L, Eugenin EA, Heary RF, Elkabes S. Toll-like receptor 9 antagonism modulates astrocyte function and preserves 
proximal axons following spinal cord injury. Brain Behav Immun. 2019 Aug;80:328-43.

351. Jin M, Iwamoto T, Yamada K, Satsu H, Totsuka M, Shimizu M. Effects of chondroitin sulfate and its oligosaccharides on tolllike receptor-mediated IL- 6 secretion by macrophage-like J774.1 cells. Biosci Biotechnol Biochem. 2011;75(7):1283-9.

352. Campo GM, Avenoso A, Campo S, Traina P, D'Ascola A, Calatroni A. Glycosaminoglycans reduced inflammatory response by modulating toll-like receptor-4 in LPS-stimulated chondrocytes. Arch Biochem Biophys. 2009 Nov;491(1-2):715.

353. Tran AP, Warren PM, Silver J. The Biology of Regeneration Failure and Success After Spinal Cord Injury. Physiol Rev. 2018 Apr 1;98(2):881-917.

354. Orecchioni M, Ghosheh Y, Pramod AB, Ley K. Macrophage Polarization: Different Gene Signatures in M1(LPS+) vs. Classically and M2(LPS-) vs. Alternatively Activated Macrophages. Front Immunol]. 2019

355. Chen Y, Song Y, Du W, Gong L, Chang H, Zhengzhi Z. Tumorassociated macrophages: An accomplice in solid tumor progression. Journal of Biomedical Science. 2019 Oct 1;26:78.

356. David S, Kroner A. Repertoire of microglial and macrophage responses after spinal cord injury. Nat Rev Neurosci. 2011 Jun 15;12(7):388-99.

357. Sharma K, Selzer ME, Li S. Scar-mediated inhibition and CSPG receptors in the CNS. Exp Neurol. 2012 Oct;237(2):370-8.

358. Zrzavy T, Schwaiger C, Wimmer I, Berger T, Bauer J, Butovsky O, et al. Acute and non-resolving inflammation associate with oxidative injury after human spinal cord injury. Brain. 2021 Feb 12;144(1):144-61. 
359. Greenhalgh AD, David S, Bennett FC. Immune cell regulation of glia during CNS injury and disease. Nature Reviews Neuroscience. 2020 Mar;21(3):139-52.

360. Francos-Quijorna I, Sánchez Petidier M, Burnside ER, TorresEspin A, Verhaagen J, Moreno-Manzano V, et al. Chondroitin sulphate proteoglycans prevent immune cell phenotypic conversion and inflammation resolution after spinal cord injury via TLR4. Nature Communications. 2021;

361. Hayashi K, Kadomatsu K, Muramatsu T. Requirement of chondroitin sulfate/dermatan sulfate recognition in midkinedependent migration of macrophages. Glycoconj J. 2001 May;18(5):401-6.

362. Rolls A, Cahalon L, Bakalash S, Avidan H, Lider O, Schwartz M. A sulfated disaccharide derived from chondroitin sulfate proteoglycan protects against inflammation-associated neurodegeneration. FASEB J. 2006 Mar;20(3):547-9.

363. Liddelow SA, Guttenplan KA, Clarke LE, Bennett FC, Bohlen CJ, Schirmer $L$, et al. Neurotoxic reactive astrocytes are induced by activated microglia. Nature. 2017 Jan 26;541(7638):481-7.

364. Rolls A, Avidan H, Cahalon L, Schori H, Bakalash S, Litvak V, et al. A disaccharide derived from chondroitin sulphate proteoglycan promotes central nervous system repair in rats and micet. European Journal of Neuroscience. 2004;20(8):1973-83.

365. Panaro MA, Lofrumento DD, Saponaro C, Nuccio FD, Cianciulli A, Mitolo V, et al. Expression of TLR4 and CD14 in the Central Nervous System (CNS) in a MPTP Mouse Model of Parkinson'sLike Disease. Immunopharmacology and Immunotoxicology. 2008 Jan 1;30(4):729-40.

366. Wang B, Shen P-F, Qu Y-X, Zheng C, Xu J-D, Xie Z-K, et al. miR940 promotes spinal cord injury recovery by inhibiting TLR4/NFKB pathway-mediated inflammation. Eur Rev Med Pharmacol Sci. 2019 Apr;23(8):3190-7. 
Bibliographical References

367. Butcher SK, O'Carroll CE, Wells CA, Carmody RJ. Toll-Like Receptors Drive Specific Patterns of Tolerance and Training on Restimulation of Macrophages. Frontiers in Immunology. 2018;9:933.

368. Zhao C, Pavicic PG, Datta S, Sun D, Novotny M, Hamilton TA. Cellular stress amplifies TLR3/4 induced CXCL1/2 gene transcription in mononuclear phagocytes via RIPK1. J Immunol. 2014 Jul 15;193(2):879-88. 
APPENDIX 
A)

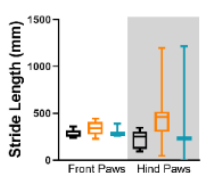

C)

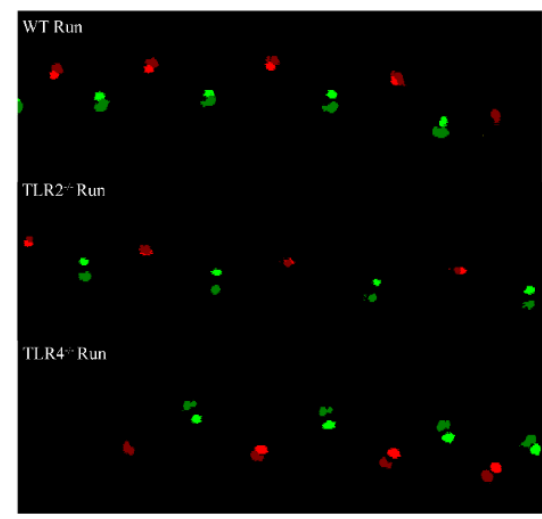

B)
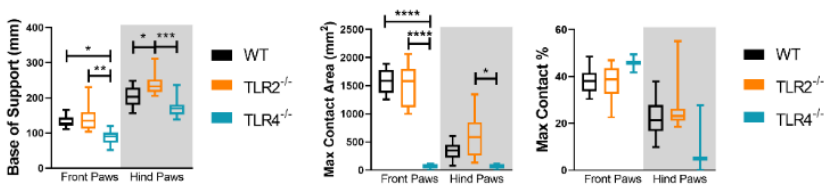

D)

Figure 49. WT, TLR2 ${ }^{-/-}$and TLR4 ${ }^{-/-}$mice stepping coordination measured by Catwalk gait analysis before SCI. A) Box and violin representation of the quantification from Stride Length (left graph) in millimetre ( $\mathrm{mm}$ ) and Base of support (right graph) in mm from Front and Hind paws. B) Box and violin representation of the quantification from Max Contact Area (left graph) in $\mathrm{mm}^{2}$ and Max contact percentage (right graph) from Front and Hind paws. C) Representative runs from WT animal + WT cells (left image) and WT animal $+\mathrm{TLR}^{-/}$cells (right image) animals. Left paws are represent in green and right paws in red. D) Bar graph representation of de the time quantification from Stand (on the left), Swing (on the middle) both in seconds from Front and Hind paws and box and violin represent percentage of Duty Cycle (on the right) from Front and Hind paws Results assessed for normality using the ShapiroWilk test and one-way ANOVA with Tukey post hoc test used to analyze differences between conditions from Front paws or Hind paws. Data shown as mean $\pm \operatorname{SEM}(\mathrm{n}=3$ animals per group). $* \mathrm{p}<0.05 ; * * \mathrm{p}<0.01 ; * * * \mathrm{p}<0.001$; $* * * * \mathrm{p}<0.0001$. 